MICROBIAL INTERACTIONS ASSOCIATED WITH BIOFILMS ATTACHED TO TRICHODESMIUM SPP. AND DETRITAL PARTICLES IN THE OCEAN

\author{
By \\ Laura Robin Hmelo \\ B.A., Carleton College, 2002 \\ Submitted in partial fulfillment of the requirements for the degree of \\ Doctor of Philosophy \\ at the \\ MASSACHUSETTS INSTITUTE OF TECHNOLOGY \\ and the \\ WOODS HOLE OCEANOGRAPHIC INSTITUTION
}

June 2010

(C) 2010 Laura R. Hmelo. All rights reserved. The author hereby grants to MIT and WHOI permission to reproduce and distribute publicly paper and electronic copies of this thesis document in whole or in part in any medium now known or hereafter created.

Author

Joint Program in Oceanography/Applied Ocean Science and Engineering Massachusetts Institute of Technology And Woods Hole Oceanographic Institution

May 11, 2010

Certified by

Dr. Benjamin A.S. Van Mooy Associate Scientist of Marine Chemistry and Geochemistry, WHOI Thesis Supervisor

Accepted by

Prof. Roger E. Summons

Professor of Earth, Atmospheric, and Planetary Sciences, MIT Chair, Joint Committee for Chemical Oceanography Woods Hole Oceanographic Institution 


\title{
MICROBIAL INTERACTIONS ASSOCIATED WITH BIOFILMS ATTACHED TO TRICHODESMIUM SPP. AND DETRITAL PARTICLES IN THE OCEAN
}

By

\author{
Laura R. Hmelo
}

Submitted to the MIT/WHOI Joint Program in Oceanography in partial fulfillment of the requirements for the degree of Doctor of Philosophy in the field of Chemical

Oceanography

\section{THESIS ABSTRACT}

Quorum sensing (QS) via acylated homoserine lactones (AHLs) was discovered in the ocean, yet little is known about its role in the ocean beyond its involvement in certain symbiotic interactions. The objectives of this thesis were to constrain the chemical stability of AHLs in seawater, explore the production of AHLs in marine particulate environments, and probe selected behaviors which might be controlled by AHL-QS. I established that AHLs are more stable in seawater than previously expected and are likely to accumulate within biofilms. Based on this result, I chose to study AHLQS in the bacterial communities inhabiting biofilms attached to Trichodesmium spp. and detrital (photosynthetically-derived sinking particulate organic carbon, POC) particles. These hot spots of microbial activity are primary sites of interaction between marine primary producers and heterotrophs and crucial components of the biological pump.

Biofilm communities associated with Trichodesmium thiebautii colonies in the Sargasso Sea differed considerably from seawater microbial communities. In addition, there was no overlap between the communities associated with tuft and puff colonies. These results suggest that bacterial communities associated with Trichodesmium are not random; rather, Trichodesmium selects for specific microbial flora. Novel 16S rRNA gene sequences are present both in clone libraries constructed from DNA extracted from colonies of Trichodesmium spp. and in culture collections derived from wild and laboratory cultivated Trichodesmium spp., supporting the idea that the phycosphere of Trichodesmium is a unique microenvironment.

Using high performance liquid chromatography-mass spectrometry, I demonstrated that bacteria isolated from Trichodesmium synthesize AHLs. In addition, I detected AHLs in sinking particles collected from a site off of Vancouver Island, Canada. AHLs were subsequently added to laboratory cultures of non-axenic Trichodesmium colonies and sinking POC samples. This is the first time AHLs have been detected in POC and indicates that AHL-QS was occurring in POC. Further, I showed that AHLs enhanced certain organic-matter degrading hydrolytic enzyme activities. My results suggest that AHL-QS is a factor regulating biogeochemically relevant enzyme activities on sinking POC and within the biofilms attached to Trichodesmium colonies and thereby may impact the timing and magnitude of biogeochemical fluxes in the ocean.

Thesis supervisor: Dr. Benjamin Van Mooy Title: Associate Scientist, Department of Marine Chemistry and Geochemistry, WHOI 


\section{ACKNOWLEDGMENTS}

The completion of this dissertation could not have been possible without numerous individuals. First and foremost, I would like to thank my advisor, Benjamin Van Mooy. It has been a tremendous privilege to be Ben's first student. After all the years that we have worked together, I have even more respect and admiration for Ben than I did when we began working together and I am surely a better scientist for having been trained by him. Over the last few years, I have been fortunate to work with a terrific thesis committee. I worked especially closely with Tracy Mincer. Tracy generously opened his lab to me and has been a significant source of advice, both scientific and professional, over the last few years. Chris Reddy and Ed DeLong both provided valuable insight and advice without which my thesis would not exist in its current manifestation. Finally, Tim Eglinton, the chair of my thesis defense, also generously contributed his time and insights which have improved this document.

I am indebted to many scientists who over the years offered me berths on cruises of opportunity. Tim Eglinton (WHOI), Bill Martin (WHOI), Bess Ward (Princeton) and Mya Breitbart (University of South Florida) all offered me opportunities to go to sea and collect data which contributed to this dissertation. Rick Keil at the University of Washington provided invaluable cruise support and the sediment net traps used to collect the data presented in Chapter 5 of this dissertation. Thank you to the captain and crews of the R/V Oceanus, R/V Endeavor, R/V Atlantic Explorer, and R/V Barnes for all that they do to ensure that our sea-time goes smoothly and that we collected the samples we set out to collect.

I could not have done the work presented here without extensive technical assistance. Helen Fredricks holds the Van Mooy lab together- From technical assistance with the mass spectrometers to making sure we have our supplies to keeping the lab stocked with chocolate, I truly could not have made it through the work presented here without her. Beyond her role as a technician and mentor, Helen has also been one of my closest friends. In addition to inspiring some of my best and most memorable times at WHOI, she kept me moving forward during some of the more difficult parts of the process. The other amazing Fye technicians- Sean Sylva, Bob Nelson, Daniel Montlucon, have always generously offered their support in any way they could.

Melissa Soule and Elizabeth Kujawinksi run the wonderful FT-ICR-MS facility at WHOI. Melissa provided support to run samples several times over the last several years, and thus has enabled some of the most scientifically exciting results I generated. Louie Kerr at the Marine Biological Laboratory enabled me to generate some really amazing confocal and scanning electron microscope images.

I must thank Academic Programs- Marsha Gomes, Julia Westwater, and Ronni Schwartz, in particular, go out of their way to make the Joint Program a smoothly running collaboration between MIT and WHOI.

The other members of the Van Mooy lab, Kim Popendorf, Justin Ossolinkski, Timothy Shanahan, and Krista Longnecker made the experience more enjoyable and for that I thank them so much. In the Mincer lab, Misty Miller has provided invaluable 
technical support and Amy Apprill has kindly shared her ARB wizardry and helped me make sense of the sequence data which appears in this dissertation. Members of the Waterbury lab, including John Waterbury, Annette Hynes, and Freddy Valois generously shared their Trichodesmium culturing expertise.

I made initial luminescence observations which inspired Chapters 3 and 4 and Appendices 1 and 2 of this dissertation during the student cruise (R/V Kilo Moana) component of the 2007 Agouron Institute summer course "Microbial Oceanography: Genomes to Biomes." I must thank the organizers of this course as well as my fellow students for allowing me the opportunity to participate in that course and the ensuing cruise.

Over the years in the Joint Program, I have had the privilege of working alongside other graduate students whom have inspired me with their intelligence, humor and compassion. While I am so sad to be parting ways with them (but only geographically!), I am so excited to see what they will accomplish over the next years. Eoghan Reeves (pizza chef extraordinaire and fellow Wire devotee) and Maya Bhatia (running buddy, climbing partner, fellow coffee addict) were with me (nearly) to the bitter end. Dave Griffith, James Saenz, Kim Popendorf, and Karin Lemkau all helped to make Fye a great place to work.

To the ghosts of Fye past: Kristin Pangallo was with me from the time I began at WHOI as a technician working with Kai-Uwe Hinrichs and then through the highs and lows of graduate school all the way until she moved on to bigger and better things a year ago. Kristin has an amazing talent to cut through academia-induced tension with spontaneous outbursts of song and dance. Desiree Plata, whom I really believe will save the world someday, has remained a source of friendship, advice, and inspiration. Nick Drenzek, the founding member of Fye After Dark, was an unforgettable character in the early years of graduate school and has remained a wonderful friend and travel buddy despite some touch-and-go moments on the Na Pali coast trail.

Erin Bertrand, although not in Fye, has become a close friend and is my go-to for advice on everything personal and professional. Emily Roland and Casey Saenger encouraged me to take a break and a bike ride now and again and I look forward to their visits in the Northwest. To everyone else I spent time with in the Joint Program, I am also deeply thankful for the time and memories that we have shared.

Adrian Rocha has become a wonderful friend and kept me smiling throughout these challenging last few months. I could pages about how fantastic Laurel Col and Brian Smith have been; they too have been with me since I first arrived as a technician at WHOI and I cherish their friendship. From weekend backpacking to weeknight dinners, they have been a part of many of my favorite memories over the last eight years. There are several friends, whom are really family, who supported me from near and far: Rana Banerjee, Katie Devine, and Katja Meyer- I can't imagine having gone through grad school or the last six years (or the last decade for that matter) without you.

My mother and father set me on this course years and years ago- I thank them for everything that they have done for me. My grandmothers have also been wonderful, from phone calls to miraculously timed care packages. 
I am grateful to my funding sources over the year. My personal funding came from an MIT Presidential Fellowship, National Science Foundation Graduate Fellowship, and the WHOI Academic Programs Office. My research was funded by grants from the National Science Foundation (Chemical Oceanography award \# 0825407), the Office of Naval Research (N0014-06-1-0134) and the Ocean Life Institute (award CH12702). 


\section{TABLE OF CONTENTS}

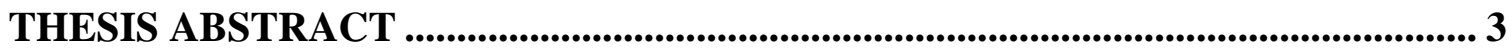

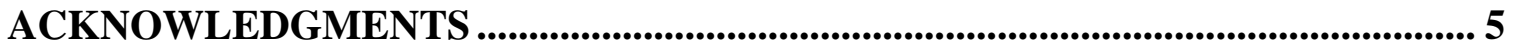

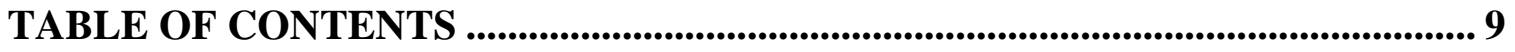

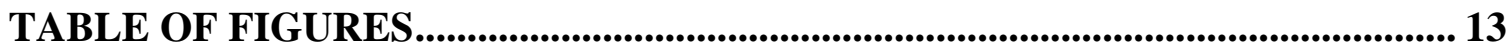

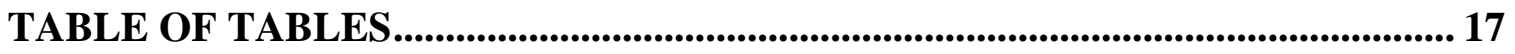

\section{CHAPTER 1: AN INTRODUCTION TO MARINE BIOFILMS AND QUORUM} SENSING

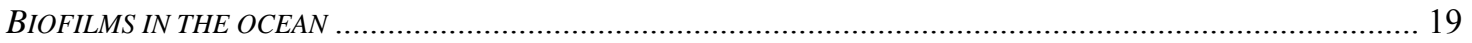

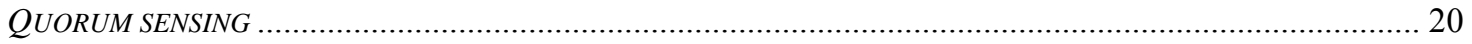

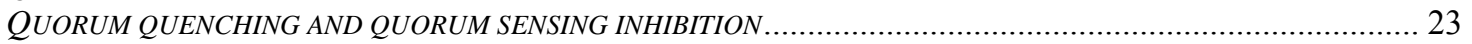

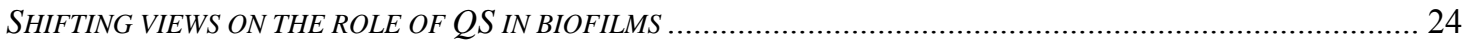

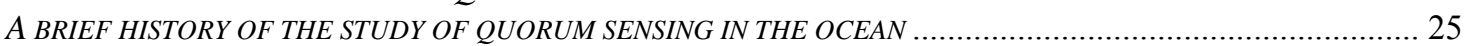

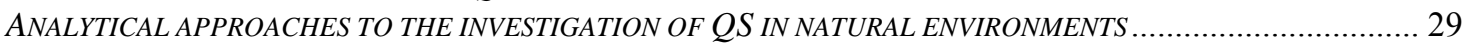

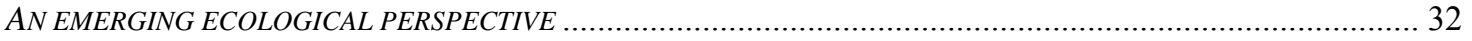

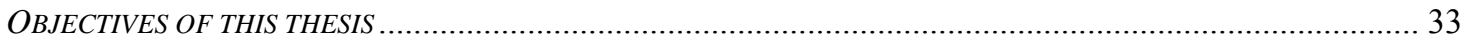

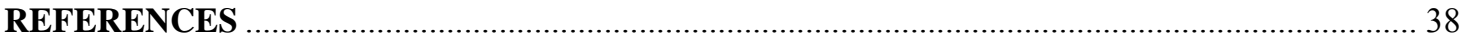

CHAPTER 2: KINETIC CONSTRAINTS ON ACYLATED HOMOSERINE LACTONE-BASED QUORUM SENSING IN MARINE ENVIRONMENTS......... 47

ABSTRACT .
INTRODUCTION
METHODS...
Incubation design
Extraction and analysis of AHLs
Incubation media
Data Analysis
RESULTS
DISCUSSION
REFERENCES

CHAPTER 3: COMBINED BIOSENSOR AND HPLC-MS APPROACH TO THE ANALYSIS OF ACYLATED HOMOSERINE LACTONE SIGNALS FROM COMPLEX SAMPLE-MATRICES: APPLICATION TO THE ANALYSIS OF AHLS PRODUCED BY EPIBIONTS OF WILD TRICHODESMIUM SPP........... 69

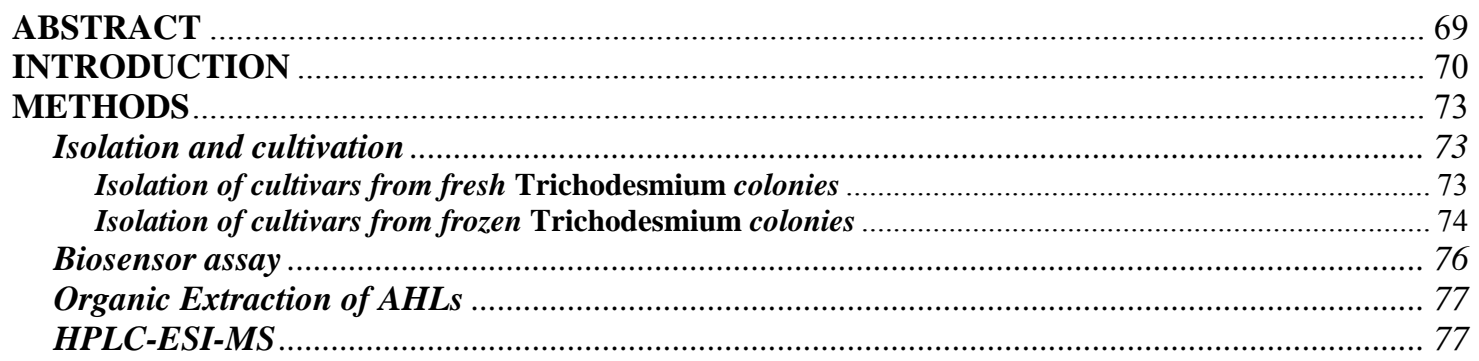




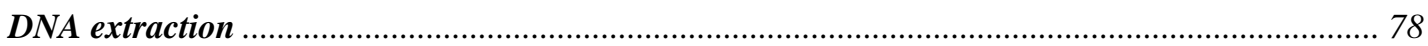

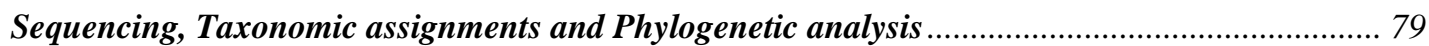

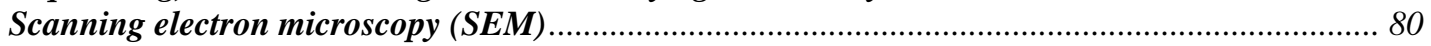

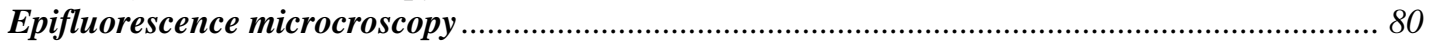

RESULTS

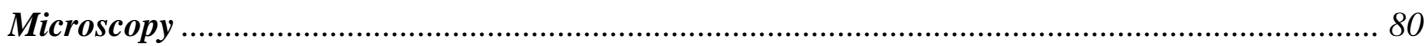

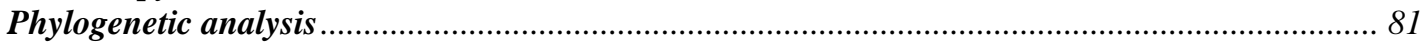

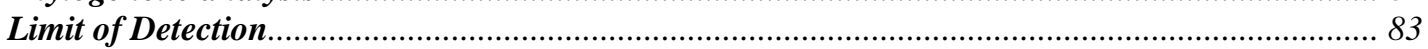

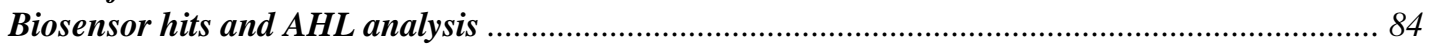

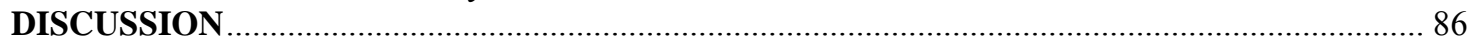

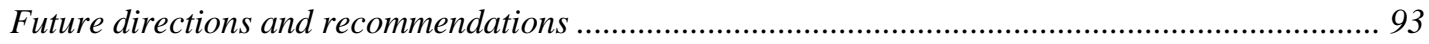

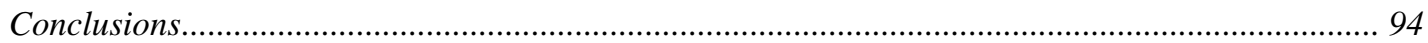

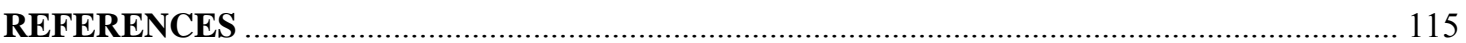

CHAPTER 4: TRICHODESMIUM THIEBAUTII COLONIES AT THE

BERMUDA ATLANTIC TIME SERIES STATION ARE ASSOCIATED WITH DISTINCTIVE EPIBIONT POPULATIONS........................................................... 121

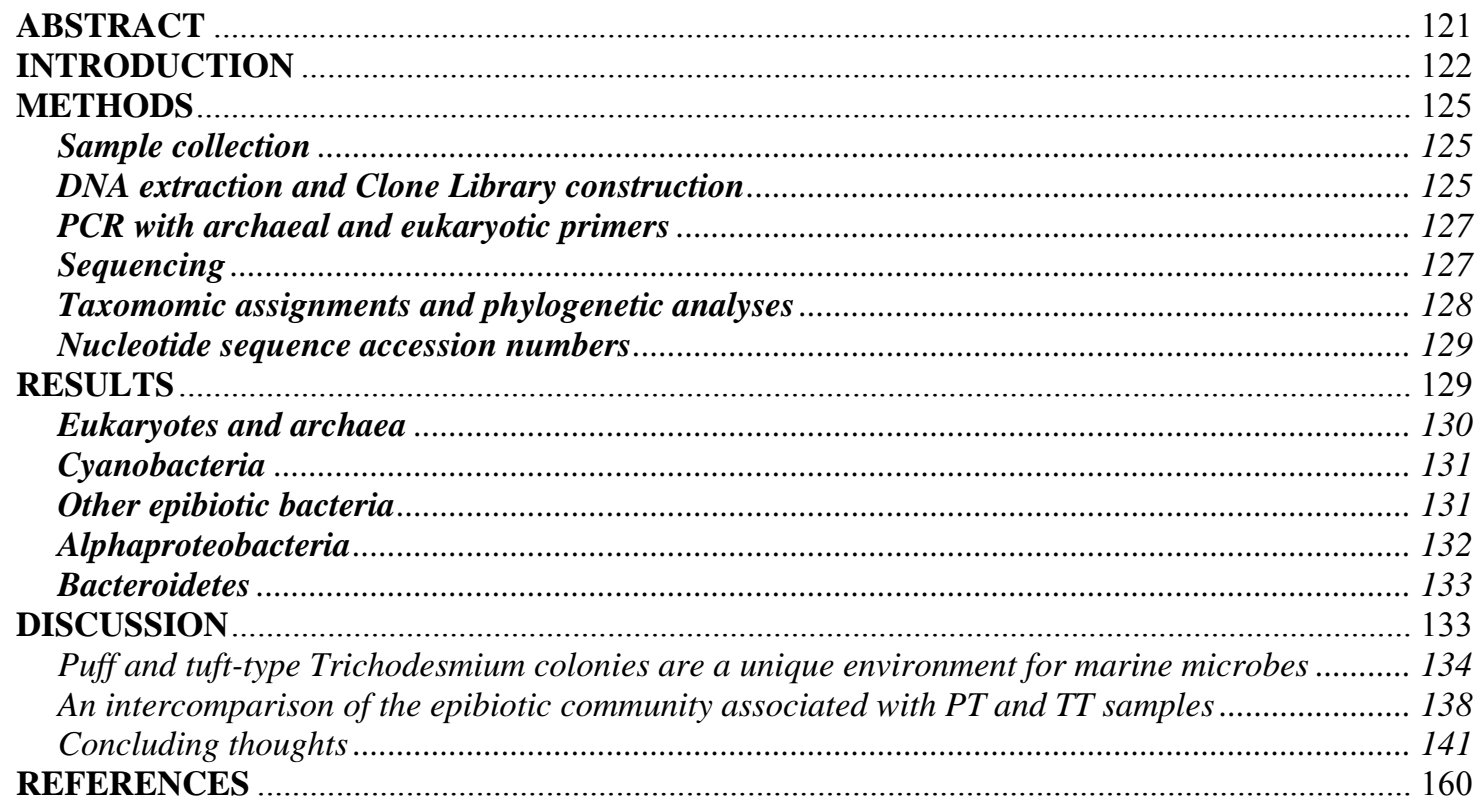

CHAPTER 5: BACTERIAL COMMUNICATION REGULATES THE DEGRADATION OF SINKING ORGANIC MATTER IN THE SEA.................. 165

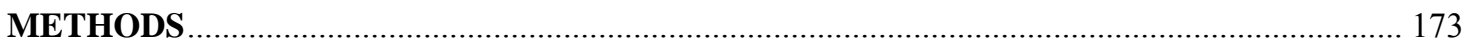

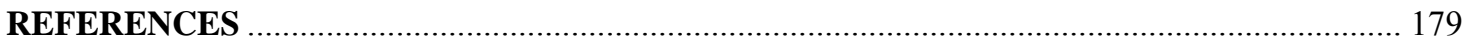

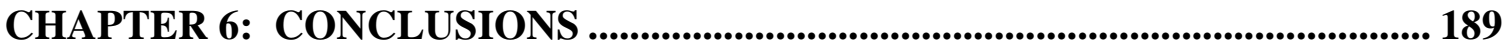

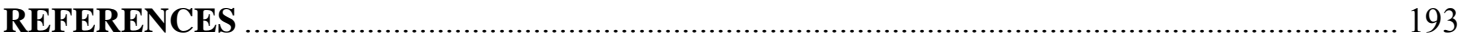

APPENDIX I: INTER-COMPARISON OF EPIBIONT COMMUNITIES

ASSOCIATED WITH LABORATORY-CULTIVATED TRICHODESMIUM

OBTAINED FROM THE CULTURE COLLECTION AT THE WOODS HOLE

OCEANOGRAPHIC INSTITUTION ............................................................ 195

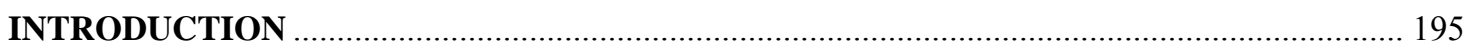




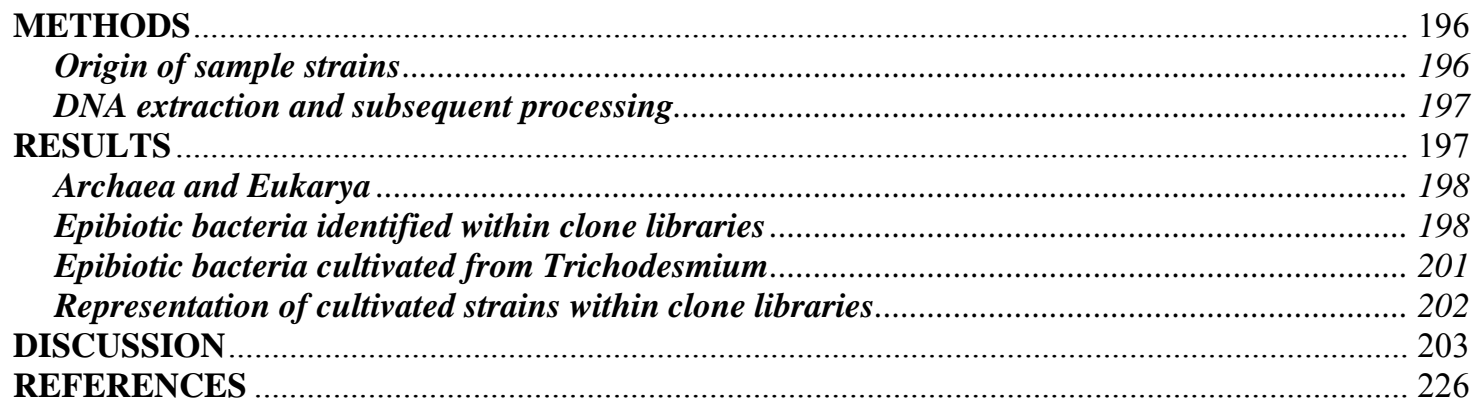

\section{APPENDIX 2: BIOLUMINESCENCE OF TRICHODESMIUM AND AN INVESTIGATION OF QUORUM SENSING BY MEMBERS OF TRICHODESMIUM CONSORTIA............................................................................. 229}

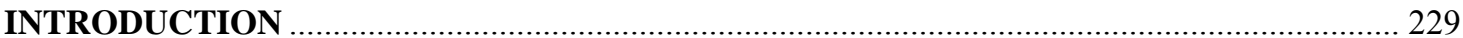

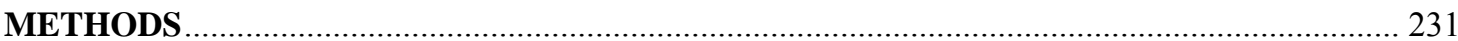

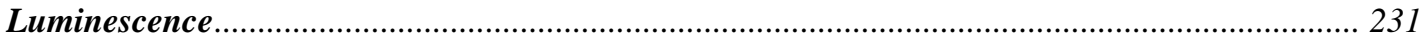

Evaluation of culture extracts for AHLs......................................................................... 231

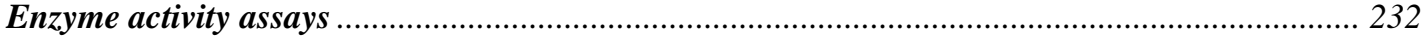

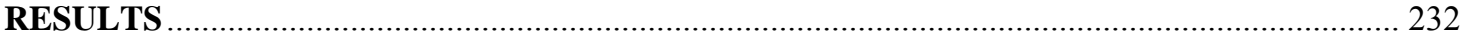

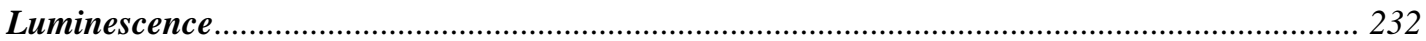

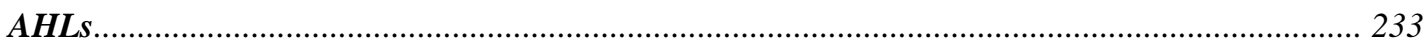

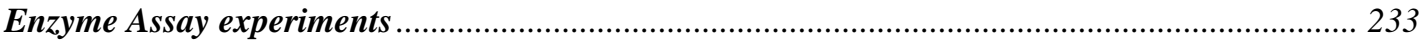

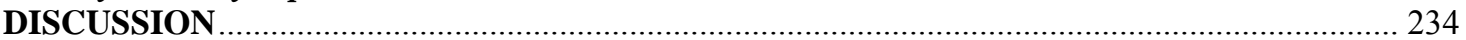

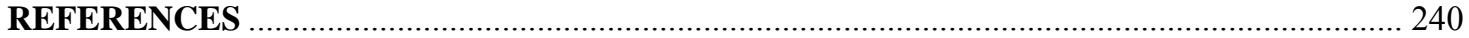

APPENDIX 3: MEASUREMENT OF THE ACTIVATION ENERGY OF HEXANOYL-HOMOSERINE LACTONE IN ARTIFICIAL SEAWATER......... 241 


\section{TABLE OF FIGURES}

Chapter 1. An introduction to marine biofilms and quorum sensing

Figure 1. Generalized structure of acylated homoserine

lactones

Chapter 2. Kinetic constraints on acylated homoserine lactone-based quorum sensing in marine environments

Figure 1. Extracted ion chromatograms from HPLC/ESIMS of AHLs used in this study

Figure 2. $\quad$ Plot of C6-HSL concentration over time during incubation in seawater from Vineyard Sound, Massachusetts

Figure 3. Bar graph depicting the degradation rates of C6HSL, 3OC6-HSL and 3OC8-HSL in four different aqueous media.

Figure 4. Plot of the degradation rate of various AHLs in $0.22 \mu \mathrm{m}$ filtered seawater versus the length of the acyl-side chain

Chapter 3. Combined biosensor and HPLC-MS approach to the analysis of acylated homoserine lactone signals from complex sample matrices: Application to the analysis of AHLs produced by epibionts of wild Trichodesmium spp.

Figure 1. SEM images of Trichodesmium erythraeum 96 strain K-11\#131

Figure 2. $\quad$ Epifluorescence image of T. erythraeum strain 97 K-11\#131

Figure 3. $\quad$ Extracted ion chromatogram from the FT-ICR- 98 MS showing the intensity of ions with a nominal mass-to-charge ratio of 284

Figure 4. Pie chart illustrating class-level distribution of 99 isolates obtained in this study.

Figure 5. Neighbor-joining phylogenetic tree detailing 100 relationships between Trichodesmium epibiont cultivars classified as (a) Alphaproteobacteria (b) Gammaproteobacteria (c) Actinobacteria and (d) Firmicutes and Bacteroidetes and reference species from GenBank. 


\section{Chapter 4. Trichodesmium thiebautii colonies at the Bermuda Atlantic Time Series station are associated with distinctive epibiont populations}

Figure 1. Rarefaction curve, calculated at 97 PSI, of puft-

145 type (PT) and tuft-type (TT) libraries

Figure 2. $\quad$ Pie charts representing the class-level phylogenetic composition (at $97 \mathrm{PSI}$ ) of (a) PT and TT libraries and (b) Sargasso Sea bacterioplankton (for reference)

Figure 3. Pie charts representing the family-level phylogenetic composition (at 97 PSI) of sequences in the PT and TT libraries which belong to the following classes: (a) Cyanobacteria (b) Alphaproteobacteria (b) Bacteroidetes

Figure 4. Neighbor joining phylogenetic tree containing

(a) cyanobacterial (b) proteobacterial and (c) all other sequences recovered from PT and TT colonies.

Figure 5. Neighbor joining phylogenetic tree containing proteobacterial sequences recovered from PT and TT colonies.

Figure 6. Neighbor joining phylogenetic tree containing all sequences recovered from PT and TT colonies which were not categorized as cyanobacterial or proteobacterial as well as detailed trees of (a) Group 2 and (b) Group 4 sequences in which sequences differ by greater than $3 \%$.

\section{Chapter 5. Bacterial communication regulates the degradation of sinking organic matter in the sea}

Figure 1. HPLC/ESI-MS data showing the presence of endogenous AHLs present in POC from a moored sediment trap

Figure 2. Results of protease, lipase and phosphotase activities in sinking POC in response to amendments with AHLs

Supplemental Conceptual illustration of QS activity within Figure 1. sinking POC

Supplemental Results of chitinase, $\alpha$ - and $\beta$-glucosidase Figure 2. activities in sinking POC in response to amendments with AHLs 
Chapter 5. Bacterial communication regulates the degradation of sinking (cont'd) organic matter in the sea

Supplemental Plot of POC flux versus depth for three scenarios 186 Figure 3.

Appendix Inter-comparison of epibiont communities associated with

1 laboratory-cultivated Trichodesmium obtained from the culture collection at the Woods Hole Oceanographic Institution

Figure 1. Rarefaction curve containing IMS101, K-11\#131， 208 H9-4A and Chapter 4 datasets

Figure 2. Pie chart illustrating class level comparison of K- 209 11\#131, IMS101 and H9-4A

Figure 3. Neighbor joining tree detailing phylogenetic 210 relationships between alphaproteobacterial sequences obtained in this study

Figure 4. Neighbor joining tree detailing phylogenetic relationships between gammaproteobacterial sequences obtained in this study

Figure 5. Neighbor joining tree detailing phylogenetic relationships between all sequences not included in Figures 4 and 5

\section{Appendix Quorum sensing among epibionts of Trichodesmium spp.}

2

Figure 1. Results of $\beta$-glucosidase and lipase activities in

Trichodesmium colonies in response to amendments with AHLs

Appendix Measurement of the activiation energy of hexanoylhomoserine lactone in artifical seawater

Figure 1. Plot of the natural log of the degradation rate of C6-HSL in artificial seawater versus the temperature at which the rate was measured 


\section{TABLE OF TABLES}

Chapter 1. Introduction

Table 1.

Summary of analytical techniques

36

Chapter 3. Combined biosensor and HPLC-MS approach to the analysis of acylated homoserine lactone signals from complex sample matrices: Application to the analysis of AHLs produced by epibionts of wild Trichodesmium spp.

Table 1. Biosensor hit table

Table 2.

AHLs identified in isolates cultivated in this

106

Supplemental study

Table 1.

Nearest GenBank neighbors of cultivars

106

Supplemental isolated from fresh Trichodesmium colonies

Table 2.

Nearest GenBank neighbors of cultivars

112 isolated from frozen Trichodesmium colonies

Chapter 4. Trichodesmium thiebautii colonies at the Bermuda Atlantic Time Series station are associated with distinctive epibiont populations

Table 1.

Statistical description of PT and TT clone

Supplemental libraries and Sargasso Sea bacterioplankton

Table 1. Nearest GenBank neighbors of 97 PSI OTUs present within 16S rRNA gene clone libraries construsted from DNA from TT Trichodesmium colonies

Supplemental Nearest GenBank neighbors of 97 PSI OTUs

Table 2. present within 16S rRNA gene clone libraries construsted from DNA from PT

Trichodesmium colonies

Appendix Intercomparison of epibiont communities associated with laboratory-cultivated Trichodesmium obtained from the culture collection at the Woods Hole Oceanographic Institution

Table 1 .

Table 2 .
Statistical description of K-11\#131, IMS101 and $\mathrm{H} 9-4 \mathrm{~A}$ clone libraries Nearest GenBank neighbors of 97 PSI OTUs present within $16 \mathrm{~S}$ rRNA gene clone libraries construsted from DNA from T. erythraeum strain K-11\#131 


\section{Appendix Intercomparison of epibiont communities associated with}

1

(cont'd)

\section{laboratory-cultivated Trichodesmium obtained from the \\ culture collection at the Woods Hole Oceanographic \\ Institution}

Table 3.

Nearest GenBank neighbors of 97 PSI OTUs

219

present within 16S rRNA gene clone libraries

construsted from DNA from $T$. thiebautii

strain H9-4A

Table 4 .

Nearest GenBank neighbors of 97 PSI OTUs

221

present within 16S rRNA gene clone libraries construsted from DNA from $T$. erythraeum strain IMS101

Table 5 .

Nearest GenBank neighbors of 97 PSI OTUs

222

present within 16S rRNA gene clone libraries construsted from DNA from isolates

cultivated from K-11\#131

Table 6 .

Nearest GenBank neighbors of 97 PSI OTUs

present within 16S rRNA gene clone libraries construsted from DNA from isolates cultivated from $\mathrm{H} 9-4 \mathrm{~A}$

Table 7 .

Nearest GenBank neighbors of 97 PSI OTUs

present within 16S rRNA gene clone libraries construsted from DNA from isolates cultivated from IMS101

\section{Appendix Quorum sensing among epibionts of Trichodesmium spp.}

2

Table 1.

Table of compiled luminescence data collected at BATS 


\section{CHAPTER 1:}

\section{AN INTRODUCTION TO MARINE BIOFILMS AND QUORUM SENSING}

\section{Biofilms in the ocean}

Biofilm-associated bacteria are key components in the global cycles of carbon and nitrogen, primarily through their role in the degradation of organic carbon and they are ubiquitous in the marine environment (Decho, 2000). They consist of dense bacterial populations embedded in an exopolysaccharide (EPS) matrix that binds bacteria to each other and to surfaces (Costerton et al., 1995). Although biofilms on suspended particles typically contribute to less than $10 \%$ of the total bacterial population in the marine water column, they are at times responsible for $41-99 \%$ of extracellular enzyme production (Karner \& Herndl, 1992; Smith et al., 1995). Consequently, bacterial biofilms contribute significantly to the remineralization of organic material in the ocean (Decho, 2000).

Biofilm-associated bacterial communities in the marine water column are composed of different taxonomic groups of bacteria than free-living communities (DeLong et al., 1993). DeLong and colleagues (1993) constructed small subunit rRNA gene clone libraries from DNA extracted from particle-attached and free-living bacteria collected in the Santa Barbara Channel off the west coast of the United States. They compared the diversity of rRNA clones from the two communities by restriction fragment length polymorphism (RFLP) analysis. Significantly, they found no overlapping restriction fragments between the two groups of samples. They determined that the planktonic communities were dominated by Alpha- and Gammaproteobacteria while 
sinking particles within the same waters were dominated by Gammaproteobacteria (phylogenetically distinct from their free-living counterparts), Cytophaga, and

Planctomyces. Since 1993, culture-independent techniques have repeatedly demonstrated that biofilms communities associated with particles and those which are free-living differ significantly in both species diversity and distribution. In addition, they necessarily express a different suite of phenotypes which are required for a surface-attached existence (Costerton et al., 1995; Sauer \& Camper, 2001; Whiteley \& Greenberg, 2001; Pasmore \& Costerton, 2003).

\section{Quorum sensing}

After planktonic bacteria initially attach to a surface, they proliferate and form clonal microcolonies. In the natural environment, these clonal populations contend with a multispecies community in which they must compete for niche space and nutrients. By necessity, each clonal population living within a biofilm must be capable of engaging in competition and cooperation in order to survive.

Quorum-sensing (QS) is a mechanism by which bacteria coordinate and cooperate with one another (Waters \& Bassler, 2005). Gram-negative QS bacteria synthesize and respond to small $(<400 \mathrm{Da})$, diffusible chemical signals to gauge the density of their clonal population and engage in group-beneficial behaviors at high population density. These 'behaviors' aid in the colonization of a particular niche, the acquisition of nutrients and the expression of collective-defenses (Badri et al., 2009). Specific QS-controlled phenotypes include bioluminescence, the production of antibiotic compounds to ward off 
competitors, the production of extracellular hydrolytic enzymes to degrade complex organic substrate and the production of the EPS biofilm matrix.

When a diffusible product (e.g. enzyme or antibiotic) is produced or a biofilm phenotype is expressed (e.g. EPS production), it is advantageous to restrict the behavior until a critical mass of bacteria accumulates (Keller \& Surette, 2006). By producing diffusible products in a coordinated fashion, the individual is ensured a greater return on the energetic investment in their production (Vetter et al., 1998). Similarly, members of a mature biofilm are capable of exploiting the benefit of collective defense (provided by the biofilm EPS matrix or antibiotic production) (Keller \& Surette, 2006). By limiting the production of energetically expensive chemicals until they can be used most efficiently, QS serves to enhance the survival of the individual and enhance the fitness of the clonal population (Keller \& Surette, 2006).

In its most basic form, a quorum sensing system involves a gene that transcribes a signal molecule synthase protein, a chemical signal produced by the signal synthase, and a gene that transcribes a response regulator protein that responds to a signal and is capable of initiating or upregulating transcription of QS-regulated genes (Miller \& Bassler, 2001; Waters \& Bassler, 2005; Dickschat, 2010). At low population densities, signals are produced by a bacterium at a basal level and they diffuse out of the cell and into the extracellular environment. The bacterium interprets the concentration of the signal molecules as a proxy for the density of like-bacteria. As the concentration of the signals in the extracellular environment reaches a threshold level, they bind to the response regulator which initiates transcription of downstream QS-regulated genes. 
Transcription is initiated simultaneously by all the members of the population such that the genes are synchronously expressed.

A variety of classes of bacterial QS signal molecules have been identified. They are all secondary metabolites that are not involved in primary metabolism (Keller \& Surette, 2006). Acylated homoserine lactones (AHLs, Eberhard et al., 1981), peptides (Novick \& Muir, 1999), quinolones (Pesci et al., 1999), furanosyl-borate diesters (Chen et al., 2002) and gamma-butyrolactones (Onaka et al., 1995) all function as intercellular signaling molecules. AHLs are the most common autoinducers produced by Proteobacteria (Lazdunski et al., 2004), the most abundant bacteria in the oceans (Giovannoni \& Rappe, 2000; Rusch et al., 2007).

Thus far, homologues of the LuxI AHL-synthase (encoded by the luxI gene) have only been observed in the Alpha-, Beta- and Gammaproteobacteria (Case et al., 2008). As of $2008,26 \%$ of proteobacterial genomes (68 in total) contained luxI homologues (Case et al., 2008) although the number of Proteobacteria in culture which produce AHLs is much higher (reviewed in Dickschat, 2010). Recently, several reports indicate that AHL-production might be a more widespread phenomenon. Paggi and co-workers observed putative AHL production in the haloalkaliphilic archaeon Natronococcus occultus (Paggi et al., 2003). More recently AHLs have been structurally identified in extracts of a cyanobacterium (Sharif et al., 2008) and a member of the Bacteroidetes (Romero, 2010) although AHL synthase genes (luxI) have yet to be identified in these organisms. 
Taxonomic specificity of AHLs is conferred by structural variations on the acyl side chain. They can vary in the length and degree of unsaturation of the acyl-side chain and the substitutions on the 3-carbon (Figure 1). AHLs with branched acyl-side chains have recently been identified (Thiel et al., 2009). In addition, aryl-homoserine lactones have been discovered; these molecules are synthesized by LuxI homologues and mediate cell-density dependent processes in the same manner as AHLs (Schaefer et al., 2008).

\section{Quorum quenching and quorum sensing inhibition}

As QS is a mechanism by which bacteria in a biofilm can coordinate with one another to achieve a competitive behavior, QS can be a target of antagonistic bacteria. AHLs can be degraded by abiotic mechanisms which include base hydrolysis of the lactone ring (Yates et al., 2002) and Claisen-like condensation to tetramic acids (Kaufmann et al., 2005). In addition, AHLs can be biologically degraded by targeted AHL-acylases or AHLlactonases (Dong \& Zhang, 2005). Prior to the work presented in this thesis, quorum quenching by enzymatic means had not yet been demonstrated in marine environments, although it has been observed in terrestrial environments (Wang \& Leadbetter, 2005). In addition to enzymatic quorum quenching, antagonistic bacteria and eukaryotes can produce chemicals capable of desensitizing the response regulators of competing bacteria. For example, Dulla and colleagues (2009) observed that bacterial epiphytes associated with the surface of leaves, were capable of prematurely inducing QS by the plant pathogen Pseudomonas syringae by producing $P$. syringae's cognate autoinducer, 3-oxo-C6-HSL. In this manner, the swarming motility of $P$. syringae is suppressed and it 
is unable to induce disease symptoms on the leaf surface. In the marine environment, the red algae Delisea pulchra has been observed to produce halogenated furanone compounds which interfere with the AHL-sensing response regulator, the LuxR protein, effectively preventing bacteria from settling on its surface (Manefield, 1999).

\section{Shifting views on the role of QS in biofilms}

The canonical role of QS is that it regulates population-density dependent gene expression; this view emerged from studies of bacteria grown in liquid batch cultures where cell densities exceed $10^{6}$ cells $\mathrm{mL}^{-1}$ and absolute populations are orders magnitude greater. As QS is studied in the context of biofilms, such as on the surface of leaves (Dulla \& Lindow, 2008) or within the rhizosphere of plants (Gantner et al., 2006), this prevailing view of QS is coming under scrutiny. Even within the traditional model of QS, AHL concentration is decoupled from cell density because signal production is often positively regulated by the signal molecules themselves (autoinduction) and quorum quenching processes actively consume AHLs as they are produced (Dunn \& Stabb, 2007).

"Efficiency-sensing" has been proposed as more appropriate description of the biochemical processes typically referred to as QS (Hense et al., 2007). This term reflects the emerging acceptance that AHL-mediated biochemistry responds not only to population density, but to the spatial distribution or confinement of cells and masstransfer properties of the environment (e.g. the hydrophobicity of a biofilm matrix) (Redfield, 2002; Hense et al., 2007; Boyer \& Wisniewski-Dyé, 2009). It is becoming 
clear that QS is not only induced at high population densities typical of liquid cultures but also within small numbers of spatially discrete cells under appropriate physical circumstances which allow signal molecules to accumulate (e.g. Dulla \& Lindow, 2008). In fact, under the right conditions, a single cell can be a 'quorum' (Gantner et al., 2006; Carnes et al., 2010). This new view of QS may be particularly meaningful when applied to bacteria embedded in hydrophobic biofilm matrices which restrict the diffusion of signal molecules; if QS can be induced by one cell, or tens of cells, QS may be more widespread in marine biofilms than previously considered.

\section{A brief history of the study of quorum sensing in the ocean}

The Hawaiian bobtail squid, Euprymna scolopes, along with numerous other marine squids and fishes, contains a light organ which is fueled by an extremely dense monoculture of the luminescent bacterium Vibrio fischeri (Ruby \& Lee, 1998). It was demonstrated that $V$. fischeri regulates the emission of light in a cell-density dependent manner via diffusible 'autoinducer' signals (AHLs) in the process which would become known as 'quorum sensing' (Nealson et al., 1970; Eberhard et al., 1981; Fuqua et al., 1994). The discovery of QS resulted from studies of the cell-density dependent bioluminescence of $V$. fischeri and since then, QS has been observed by numerous bacteria from a wide range of environments.

Although the vast majority of research has explored the role of QS in clinical isolates, numerous QS-capable proteobacteria have been isolated from marine snow (Gram et al., 2002), corals (Tait et al., 2010), sponges (Mohamed et al., 2008) and 
dinoflagellates (Wagner-Dobler et al., 2005). In all of these cases, QS isolates have been Alpha- and Gammaproteobacteria. Hence, QS bacteria can be isolated from a wide range of marine environments without significant difficulty. These cultivation efforts remain valuable endeavors as these efforts continue to expand the landscape of known QScapable genera (e.g. Thalassomonas and Spongiobacter, Mohamed et al., 2008). These isolates will be a valuable resource as scientists continue to explore the role of QS in environmental bacteria.

While the isolation of QS-capable bacteria from marine environments indicates that a genetic capability for QS exists in this environment, it does not provide insight into in-situ QS activity. However, the results of several studies that report the presence of AHLs in marine samples imply that QS is occurring in natural marine microbial communities. For example, AHLs were detected in extracts of corals, by both biosensor and mass spectrometry, indicating that AHLs are produced by coral-associated bacteria in-situ (Taylor et al., 2004). More recently, AHLs have been identified using sensitive mass spectrometric techniques in extracts of stromatolites (Decho et al., 2009). AHLs have been demonstrated to stimulate the settlement of zoospores of the macroalgae Ulva intestinalis (Tait et al., 2005) and Enteromorpha (Joint et al., 2002). AHL-QS has also been implicated in large-scale bioluminescence events coincident with algal blooms (Nealson \& Hastings, 2006), in the degradation of organic carbon (Gram et al., 2002; Ziervogel \& Arnosti, 2008) and in the regulation of algal blooms (Nakashima et al., 2006). 
Only a handful of studies have probed the dynamics of QS in natural environments. These studies provide insight into QS behavior in complex, multi-species environments which are difficult to replicate in the laboratory. In 2007, Huang and colleagues demonstrated that biofilms grown in the subtidal zone on petri dishes induced positive results by different biosensors at different stages of maturity (Huang et al., 2007). This study was followed by one which replicated the latter results and provided conclusive mass spectral data confirming that different suites of AHLs were produced at different times (Huang et al., 2008). These results imply that the suite of AHLs produced in a maturing multi-species biofilms is variable over time, which may reflect the succession of microbial taxa during biofilm-development. Decho and colleagues (2009) recently demonstrated that variability in AHL concentrations in natural stromatolites corresponds with diel variability. The variability is coincident with changes in $\mathrm{pH}$ within the stromatolite over the twenty-four hour period. They postulated that bacteria might differentially exploit AHLs based on their sensitivity to the alkaline conditions which develop in microbial mats during daylight hours; this would allow them to alternate the induction of particular gene sets on a day/night schedule (Decho et al., 2009). Finally, Valle and colleagues (2004) were able to demonstrate that the addition of AHLs to an industrial wastewater treatment system induced changes in both the microbial community composition and ability of that community to degrade phenol. They concluded that AHL-mediated gene expression influenced the composition and function of the endogenous microbial community. 
Together, these three studies offer tantalizing glimpses into QS by bacteria in complex environments. Undoubtedly, we will learn more about these systems in the coming years, but there are many others which remain to be explored. In this thesis, I initiated investigations into QS within two heretofore unexplored environments: the phycosphere of Trichodesmium spp. and bacterial communities attached to sinking particulate organic matter. These studies will be discussed further in a subsequent section of this Introduction.

The marine environment presents unique challenges to QS bacteria. First, the aqueous environment is one in which signals can be lost by diffusion very rapidly. Second, seawater is slightly basic ( $\mathrm{pH} 8.2$ ) and AHLs may be rapidly degraded by basecatalyzed hydrolysis (Yates et al., 2002). Finally, in addition to the challenges presented by the abiotic environment, it is also likely that biological quorum quenching is a prevalent threat to QS bacteria.

Some of the physical challenges presented by the marine environment (e.g. diffusion) may be mitigated within biofilms. Within biofilms, the $\mathrm{pH}$ is generally lower (by up to $2 \mathrm{pH}$ units) than that of the ambient environment (Vroom et al., 1999; Horswill et al., 2007 and references therein) which will slow the degradation of AHLs by abiotic base-catalyzed hydrolysis. In addition, biofilm structure may physically dramatically limit loss of AHLs by diffusion.

Marine bacteria seem to have evolved strategies to contend with some of the challenges presented to them by their chemical environment. For example, they tend to use long-chain AHLs or AHLs with oxo-substitutions on the 3-carbon of the acyl chain 
(Wagner-Dobler et al., 2005; Huang et al., 2008). Compared to short-chain AHLs, longchain AHLs are more stable molecules in seawater; they degrade more slowly by basecatalyzed hydrolysis (Yates et al., 2002; Hmelo \& Van Mooy, 2009). Interestingly, longchain AHLs are less soluble than short chain AHLs; the $\log \mathrm{P}$ (octanol-water partition coefficient) of unsubstituted-AHLs of chain lengths $C_{4}$ to $C_{12}$ varies from -0.11 to 4.9. The hydrophobic chemistry of the biofilm matrix may help to concentrate longer-chain AHL homologues (Horswill et al., 2007 and references therein), suggesting that longchain AHLs may be more effective within biofilms in comparison to a more aqueous setting. On the other hand, oxo-substituted AHLs are substantially more soluble than their unsubstituted homologues; the oxo-substitution lowers the $\log \mathrm{P}$ of an unsubstituted-AHL of a given chain length by 1.26 units. Whether long chain unsubstituted AHLs are preferentially utilized within biofilms or if oxo-substituted AHLs are preferentially utilized in more aqueous environments remains to be investigated.

\section{Analytical approaches to the investigation of QS in natural environments}

Until recently, the occurrence of QS has almost always been inferred by the use of biosensor assays (McLean et al., 1997; Gram et al., 2002; Taylor et al., 2004). In these assays (Steindler \& Venturi, 2007; Dickschat, 2010) a mutant QS bacterium deficient in its ability to synthesize AHLs is monitored for an easily observable response (e.g. a color change) when it is exposed to exogenous AHLs. These assays are sensitive to the presence of AHL-like bioactivity and can detect extremely low quantities of AHL (see Table 1, Ravn et al., 2001); however, these assays are subject to false positive and false 
negative results (Holden, 1999; Ortori et al., 2007; Steindler \& Venturi, 2007; GarciaAljaro et al., 2008). In addition, each biosensor can detect only a limited suite of specific AHL molecules (Steindler \& Venturi, 2007), they are variably sensitive to those structures which they can detect (e.g. Winson et al., 1995) and they do not provide direct structural information.

Coupling biosensor analysis with thin-layer chromatography affords a degree of structural identification unattainable by use of a biosensor alone (Shaw et al., 1997). This hybrid technique has been used successfully in a number of studies to determine the AHL structures produced by environmental isolates (Gram et al., 2002; Mohamed et al., 2008; Tait et al., 2010). Unfortunately, this technique still has limitations; it is still subject to the detection biases of the biosensor and it does not detect novel AHLs or structures for which authentic standards are not available.

Radioactive assays are among the most sensitive methods by which AHLs can be detected (see Table 1). $\mathrm{C}^{14}$-radiolabelled methionine, one of the biosynthetic substrates required for the synthesis of AHLs, is incubated with a sample. The sample is extracted into ethyl acetate, separated by reverse-phase chromatography and then collected into fractions. The radioactivity of these fractions can then be assessed and retention times can be compared to standards. This approach offers the advantage of being unbiased toward particular structures and enables the detection of very low (e.g. femtomole) quantities of AHLs (Schaefer et al., 2001). Since ethyl acetate extractable compounds that incorporate methionine are almost always acyl- or aryl-homoserine lactones produced by the well-characterized AHL-biosynthetic pathway (A. Schaefer, personal 
communication) this method may be extremely effective at identifying novel AHLs, particularly if performed in parallel with mass spectrometry or nuclear magnetic resonance spectroscopy. While it has been used successfully to document production of AHLs in mucus from lungs infected with cystic fibrosis (Singh et al., 2000) and the elucidation of the novel signaling compound, $p$-coumaroyl homoserine lactone, from Rhodopseudomonas palustris (Schaefer et al., 2008), it has yet to be applied to environmental samples.

Chromatographic techniques coupled with mass spectrometry have been used extensively to identify specific AHL structures present in culture extracts and extracts from environmental samples (summarized in Table 1). Gas chromatography coupled to mass spectrometry (GC-MS) has been used to identify AHLs in extracts of environmental samples and culture extracts (Taylor et al., 2004) . Unfortunately, oxo- and hydroxylAHLs are thermally labile and require derivitization prior to analysis by GC (Cataldi et al., 2008).

High performance liquid chromatography (HPLC) is frequently utilized and can be coupled to some of the most sensitive mass spectrometers. HPLC has been coupled to fourier-transform ion-cyclotron-resonance mass spectrometry (FT-ICR-MS, Cataldi et al., 2008), hybrid quadrupole-linear ion trap mass spectrometry (Ortori et al., 2007), and triple-quadrupole mass spectrometry (Decho et al., 2009). Each of these MS techniques provides distinct advantages (summarized in Table 1). FT-ICR-MS can measure massto-charge ratios at $1 \mathrm{ppm}$ accuracy which, in combination with chromatographic retention time and/or mass fragmentation data, can allow the assignment of an elemental formula 
to an analyte of interest (e.g. Cataldi et al., 2008). Linear-quadrupole ion trap devices are capable of secondary mass spectrometry, enabling fine structural investigations of unknown analytes (e.g. Morin et al., 2003; Ortori et al., 2007). Finally, triple quadrupole devices are extremely sensitive and selective; they are capable of operating in a selected reaction monitoring (SRM) mode which allows quantitative observation of specific ions amidst an extremely complex matrix. While ion-trap MS have limits of detection (LOD) as low as 10 pmol (Morin et al., 2003), no absolute analytical limits of detection have been published for FT-ICR-MS or triple-quadrupole MS devices analyzing AHLs; however, Cataldi et al (2008) determined that FT-ICR-MS is about an order of magnitude more sensitive than ion-trap MS and so we can estimate the LOD of FT-ICR-MS to be around 1 pmol (see Table 1). All HPLC-MS approaches utilize an electrosprayionization interface, which can cause bias in the efficiency at which AHLs of different chain lengths are ionized (Ortori et al., 2007). These biases can be overcome with the use of standard curves.

\section{An emerging ecological perspective}

In laboratory cultures, QS is known to regulate extracellular hydrolytic enzyme activity (Miller \& Bassler, 2001) and the production of compounds toxic to algae (e.g. prodigiosin, Nakashima et al., 2006), two processes which may directly impact the fate of photosynthetically derived carbon in the ocean. QS has been implicated in the degradation of marine snow in the environment (Gram et al., 2002), although mechanistic studies have yet to be published. It is also becoming clear that QS may be involved in the 
recruitment of eukaryotes to living and artificial surfaces in the ocean (Tait et al., 2005; Dobretsov et al., 2007). We might speculate from this that QS is also involved in the recruitment of eukaryotes to the surface of detrital particles as well. In recent years, several reviews have addressed the occurrence of QS in marine habitats (Cicirelli et al., 2008; Dobretsov et al., 2009; Decho et al., 2010; Dickschat, 2010), reflecting a growing awareness that QS is prevalent in marine microbial communities.

\section{Objectives of this thesis}

QS is an understudied process in the oceans. Despite the extensive progress which has been achieved regarding the biochemistry of QS, very little is known about the basic occurrence in the environment (particularly in the marine environment) and the specific phenotypes controlled by QS in environmental bacteria. Most of the work has been undertaken using clinical isolates. The role of QS in marine bacteria (with the exception of symbiotic Vibrio spp.) is practically unknown.

In this thesis, I aimed to extend our knowledge of surface-attached bacterial communities in the ocean and the role which QS may play in those communities. In Chapter 2, I undertook an investigation of the chemistry of AHLs in seawater, seeking to place constraints on where QS is most likely to occur in the marine environment, thus guiding the remaining chapters. The results of Chapter 2 suggested that the bacterial communities associated with the surface of marine phytoplankton and marine snow occur at densities capable of supporting QS behavior. 
In Chapters 3 through 5 and subsequent Appendices (1 and 2), I investigated the bacterial communities within biofilms attached to the bloom forming cyanobacterium, Trichodesmium, as well as photosynthetically-derived, detrital sinking-particulate organic carbon. In Chapter 3, I analyze a culture collection derived from Trichodesmium epibiont communities. Among the results of this study is the observation of QS in Erythrobacter, a genus within the alphaproteobacteria in which QS has not yet been observed. In Chapter 4, I employ a culture independent clone library approach to more deeply investigate the structure of the epibiont community associated with Trichodesmium spp. from the same field site as the samples used in Chapter 3 (Bermuda Atlantic Time Series station in the Sargasso Sea). I explore another microbial system in Chapter 5, in which I used a novel approach to investigate the role of QS in sinking particulate organic carbonassociated bacteria. The results of this study demonstrate for the first time that QS is involved in the regulation of extracellular enzyme production in sinking particulate organic carbon-attached bacteria. The implications of these results with regards to our understanding of the marine carbon cycle are discussed in detail.

Appendices 1 and 2 are extensions of Chapters 3-5 in which I present the results of pilot studies which further investigate the community structure of Trichodesmium spp. and the occurrence and potential functions of QS within those communities. General conclusions and suggestions for future research directions are discussed in the final chapter of this thesis. 
<smiles>[R]C(=O)NC1CCOC1=O</smiles>

I<smiles>[R]C(=O)CC(=O)NC1CCOC1=O</smiles>

II<smiles>[R]C(O)CC(=O)NC1CCOC1=O</smiles>

III<smiles>CC(C)CCCCC(=O)NC1CCOC1=O</smiles>

IV

iso ${ }_{7}-\mathrm{HSL}$, Aeromonas culicola 3249<smiles>O=C(/C=C/c1ccc(O)cc1)NC1CCOC1=O</smiles>

p-coumaroyl-HSL, Rhodopseudomonas palustris<smiles>CCCCCCC/C=C\CCCCC/C=C/C(=O)NC1CCOC1=O</smiles>

Figure 1. Examples of known AHL structures. I, II, and III represent the canonical forms in which I is an 'unsubstituted' AHL, II is a '3-oxo' AHL and III is a '3-hydroxy' AHL. $\mathrm{R}$ is an acyl side chain of length of up to 18 carbons. IV, $\mathbf{V}$, and $\mathbf{V I}$ are examples of recently elucidated structural variations. IV is an iso- $\mathrm{C}_{7}-\mathrm{HSL}$ produced by Aeromonas culicola 3249 (Thiel et al., 2009). V is p-coumaroyl-homoserine lactone, an arylhomoserine lactone, produced by Rhodopseuodomonas palustris (Schaefer et al., 2008). VI is a $\mathrm{C}_{16: 2}$-HSL produced by the alphaproteobacterium Jannaschia helgolandensis (Thiel et al., 2009). 
Table 1. Summary of analytical techniques discussed in this chapter. The mass resolution of the various mass spectrometric techniques is indicated. Low mass resolution is nominal mass resolution (' 1 '). In this dissertation, high mass resolution corresponds to 100,000 at $\mathrm{m} / \mathrm{z} 400$. ${ }^{a}$ High performance liquid chromatography (HPLC). ${ }^{\mathrm{b}} \mathrm{LCQ}, \mathrm{LTQ}$ and TSQ are not acronyms but rather nicknames for the Thermo Finnigan/Thermo LCQ Deca-XP ion trap mass spectrometer, LTQ-Ultra ion trap mass spectrometer, or TSQ triple-quadrupole mass spectrometer, respectively. Samples were introduced to all three mass spectrometers via an electrospray ionization interface. ${ }^{\mathrm{c}}$ The LOD for FT-ICR-MS is estimated from the LOD from the ion trap mass spectrometer. See text for details. ${ }^{\mathrm{d}}$ The LOD for the biosensor technique is variable and depends both on the specific biosensor in question and its sensitivity to a given AHL 


\begin{tabular}{|c|c|c|c|c|c|}
\hline Analytical Technique & Acronym & Application & $\begin{array}{c}\text { Mass } \\
\text { Resolution }\end{array}$ & $\begin{array}{l}\text { Limit of } \\
\text { Detection } \\
\text { (LOD) }\end{array}$ & References \\
\hline $\begin{array}{l}\text { HPLC }{ }^{\text {a }} \text {-Ion trap mass } \\
\text { spectrometry }\end{array}$ & $\begin{array}{l}\text { LCQ or } \\
\text { LTQ }^{b}\end{array}$ & $\begin{array}{l}\text { Molecular ion and mass } \\
\text { fragmentation for structure } \\
\text { elucidation }\end{array}$ & low & $\sim 10$ pmol & $\begin{array}{l}\text { (Morin et al., 2003; } \\
\text { Hmelo \& Van Mooy, } \\
\text { 2009) }\end{array}$ \\
\hline $\begin{array}{l}\text { HPLC- Fourier-transform ion- } \\
\text { cyclotron resonance mass } \\
\text { spectrometry }\end{array}$ & FT-ICR-MS & $\begin{array}{l}\text { Exact mass of molecular ion for } \\
\text { elemental composition for structure } \\
\text { elucidation }\end{array}$ & high & $\sim 1 \mathrm{pmol}^{\mathrm{c}}$ & (Cataldi et al., 2008) \\
\hline $\begin{array}{l}\text { HPLC- Triple quadrupole } \\
\text { mass spectrometry }\end{array}$ & $\mathrm{TSQ}^{\mathrm{b}}$ & $\begin{array}{l}\text { Highly selective selected-reaction- } \\
\text { monitoring (SRM) mode }\end{array}$ & low & unknown & (Decho et al., 2009) \\
\hline $\begin{array}{l}\text { Gas chromatography-mass } \\
\text { spectrometry }\end{array}$ & GC-MS & $\begin{array}{l}\text { Low LOD and mass fragmentation } \\
\text { for structure elucidation }\end{array}$ & low & $\sim 0.1 \mathrm{pmol}$ & $\begin{array}{l}\text { (Charlton et al., 2000; } \\
\text { T. R. I. Cataldi, G. } \\
\text { Bianco, M. } \\
\text { Frommberger, Ph. } \\
\text { Schmitt-Kopplin, } \\
\text { 2004) }\end{array}$ \\
\hline Biosensor & $\mathrm{n} / \mathrm{a}$ & Indicates AHL-like bioactivity & $\mathrm{n} / \mathrm{a}$ & $\begin{array}{l}\text { as low as }<10 \\
\text { pmol }^{d}\end{array}$ & $\begin{array}{l}\text { (McClean et al., 1997; } \\
\text { Brelles-Marino \& } \\
\text { Bedmar, 2001; Ravn et } \\
\text { al., 2001; Steindler \& } \\
\text { Venturi, 2007) }\end{array}$ \\
\hline $\begin{array}{l}\text { Biosensor- Thin layer } \\
\text { chromatography }\end{array}$ & TLC & $\begin{array}{l}\text { Adds a degree of compound- } \\
\text { specificity when coupled with } \\
\text { biosensor overlay }\end{array}$ & $\mathrm{n} / \mathrm{a}$ & $\mathrm{n} / \mathrm{a}$ & (Shaw et al., 1997) \\
\hline Radiolabel assay & $\mathrm{n} / \mathrm{a}$ & Synthesis rates & $\mathrm{n} / \mathrm{a}$ & $\sim 90 \mathrm{fmol}$ & $\begin{array}{l}\text { (Blosser-Middleton \& } \\
\text { Gray, 2001; Schaefer et } \\
\text { al., 2001) }\end{array}$ \\
\hline
\end{tabular}




\section{REFERENCES}

Badri, D. V., Weir, T. L., van der Lelie, D., \& Vivanco, J. M. (2009) Rhizosphere chemical dialogues: plant-microbe interactions. Curr Opin Biotechnol 20: 642-650.

Blosser-Middleton, R. S., \& Gray, K. M. (2001) Multiple N-acyl homoserine lactone signals of Rhizobium leguminosarum are synthesized in a distinct temporal pattern. $J$ Bacteriol 183: 6771-6777.

Boyer, M., \& Wisniewski-Dyé, F. (2009) Cell-cell signalling in bacteria: not simply a matter of quorum. FEMS Microbiol Ecol 70: 1-19.

Brelles-Marino, G., \& Bedmar, E. J. (2001) Detection, purification and characterisation of quorum-sensing signal molecules in plant-associated bacteria. J Biotechnol 91: 197-209.

Carnes, E. C., Lopez, D. A. M., Donegan, N. P., Cheung, A., Gresham, H., Timmins, G. S., \& Brinker, C. J. (2010) Confinement-induced quorum sensing of individual Staphylococcus aureus bacteria. Nat Chem Biol 6: 41-45.

Case, R. J., Labbate, M., \& Kjelleberg, S. (2008) AHL-driven quorum-sensing circuits: their frequency and function among the Proteobacteria. ISME J 2: 345.

Cataldi, T. R. I., Bianco, G., \& Abate, S. (2008) Profiling of N-acyl-homoserine lactones by liquid chromatography coupled with electrospray ionization and a hybrid quadrupole linear ion-trap and Fourier-transform ion-cyclotron-resonance mass spectrometry (LC-ESI-LTQ-FTICR-MS). J Mass Spectrom 43: 82-96.

Charlton, T. S., de Nys, R., Netting, A., Kumar, N., Hentzer, M., Givskov, M., \& Kjelleberg, S. (2000) A novel and sensitive method for the quantification of N-3oxoacyl homoserine lactones using gas chromatography-mass spectrometry: application to a model bacterial biofilm. Environ Microbiol 2: 530-541.

Chen, X., Schauder, S., Potier, N., Van Dorsselaer, A., Pelczer, I., Bassler, B. L., \& Hughson, F. M. (2002) Structural identification of a bacterial quorum-sensing signal containing boron. Nature 415: 545-549.

Cicirelli, E. M., Williamson, H., Tait, K., \& Fuqua, C. (2008) Acylated homoserine lactone signaling in marine bacterial systems. In pp. 251-272.

Costerton, J. W., Lewandowski, Z., Caldwell, D. E., Korber, D. R., \& Lappin-Scott, H. M. (1995) Microbial Biofilms. Ann Rev Microbiol 49: 711-745. 
Decho, A. W., Norman, R. S., \& Visscher, P. T. (2010) Quorum sensing in natural environments: emerging views from microbial mats. Trends Microbiol 18: 73--80.

Decho, A. W., Visscher, P. T., Tomohiro, J. F., He, K. L., Przekop, K. M., Norman, R. S., \& Reid, R. P. (2009) Autoinducers extracted from microbial mats reveal a surprising diversity of $\mathrm{N}$-acylhomoserine lactones (AHLs) and abundance changes that may relate to diel pH. Environ Microbiol 11: 409-420.

Decho, A. W. (2000) Microbial biofilms in intertidal systems: an overview. Cont Shelf Res 20: $1257-1273$.

DeLong, E. F., Franks, D. G., \& Alldredge, A. L. (1993) Phylogenetic diversity of aggregate-attached vs. free-living marine bacterial assemblages. Limnol Oceanogr 924-934.

Dickschat, J. S. (2010) Quorum sensing and bacterial biofilms. Nat Prod Rep 27: 343369.

Dobretsov, S., Teplitski, M., \& Paul, V. (2009) Mini-review: quorum sensing in the marine environment and its relationship to biofouling. Biofouling 25: 413-427.

Dobretsov, S., Dahms, H. U., Huang, Y. L., Wahl, M., \& Qian, P. Y. (2007) The effect of quorum-sensing blockers on the formation of marine microbial communities and larval attachment. FEMS Microbiol Ecol 60: 177-188.

Dong, Y. H., \& Zhang, L. H. (2005) Quorum sensing and quorum-quenching enzymes. $J$ Microbiol 43: 9.

Dulla, G., \& Lindow, S. E. (2008) Quorum size of Pseudomonas syringae is small and dictated by water availability on the leaf surface. PNAS 105: 3082-3087.

Dulla, G. F. J., \& Lindow, S. E. (2009) Acyl-homoserine lactone-mediated cross talk among epiphytic bacteria modulates behavior of Pseudomonas syringae on leaves. ISME $J 1-10$.

Dunn, A., \& Stabb, E. (2007) Beyond quorum sensing: the complexities of prokaryotic parliamentary procedures. Anal Bioanal Chem 387: 391.

Eberhard, A., Burlingame, A., Eberhard, C., Kenyon, G., Nealson, K., \& Oppenheimer, N. (1981) Structural identification of autoinducer of Photobacterium fischeri luciferase. Biochem 20: 2444-2449. 
Fuqua, W. C., Winans, S. C., \& Greenberg, E. P. (1994) Quorum sensing in bacteria: the LuxR-LuxI family of cell density-responsive transcriptional regulators. J Bacteriol 176: $269-275$.

Gantner, S., Schmid, M., Durr, C., Schuhegger, R., Steidle, A., Hutzler, P. et al. (2006) In situ quantitation of the spatial scale of calling distances and population densityindependent $\mathrm{N}$-acylhomoserine lactone-mediated communication by rhizobacteria colonized on plant roots. FEMS Microbiol Ecol 56: 188-194.

Garcia-Aljaro, C., Eberl, L., Riedel, K., \& Blanch, A. (2008) Detection of quorumsensing-related molecules in Vibrio scophthalmi. BMC Microbiology 8: 138.

Giovannoni, S. J., \& Rappe, M. S. (2000) Evolution, diversity, and molecular ecology of marine prokaryotes. In Microbial ecology of the oceans. D. L. Kirchman (ed). New York, Wiley-Liss,

Gram, L., Grossart, H., Schlingloff, A., \& Kiorboe, T. (2002) Possible quorum sensing in marine snow bacteria: Production of acylated homoserine lactones by Roseobacter strains isolated from marine snow. Appl Environ Microb 68: 4111-4116.

Hense, B. A., Kuttler, C., Müller, J., Rothballer, M., Hartmann, A., \& Kreft, J. U. (2007) Does efficiency sensing unify diffusion and quorum sensing? Nat Rev Micro 5: 230239.

Hmelo, L., \& Van Mooy, B. A. S. (2009) Kinetic constraints on acylated homoserine lactone-based quorum sensing in marine environments. Aquat Microb Ecol 54: 127133.

Holden, M. T. G. (1999) Quorum-sensing cross talk: isolation and chemical characterization of cyclic dipeptides from Pseudomonas aeruginosa and other gramnegative bacteria. Mol Microbiol 33: 1254.

Horswill, A. R., Stoodley, P., Stewart, P. S., \& Parsek, M. R. (2007) The effect of the chemical, biological, and physical environment on quorum sensing in structured microbial communities. Anal Bioanal Chem 387: 371-380.

Huang, Y. L., Ki, J. S., Lee, O. O., \& Qian, P. Y. (2008) Evidence for the dynamics of acyl homoserine lactone and AHL-producing bacteria during subtidal biofilm formation. ISME J 3: 296-304.

Huang, Y. L., Dobretsov, S., Ki, J. S., Yang, L. H., \& Qian, P. Y. (2007) Presence of acyl-homoserine lactone in subtidal biofilm and the implication in larval behavioral response in the polychaete Hydroides elegans . Microb Ecol 54: 384-392. 
Joint, I., Tait, K., Callow, M. E., Callow, J. A., Milton, D., Williams, P., \& Camara, M. (2002) Cell-to-cell communication across the prokaryote-eukaryote boundary.

Science 298: 1207-1207.

Karner, M., \& Herndl, G. J. (1992) Extracellular enzymatic activity and secondary production in free-living and marine-snow-associated bacteria. Mar Biol 113: 341347.

Kaufmann, G. F., Sartorio, R., Lee, S., Rogers, C. J., Meijler, M. M., Moss, J. A. et al. (2005) Revisiting quorum sensing: Discovery of additional chemical and biological functions for 3-oxo-N-acylhomoserine lactones. PNAS 102: 309-314.

Keller, L., \& Surette, M. G. (2006) Communication in bacteria: an ecological and evolutionary perspective. Nat Rev Micro 4: 249-258.

Lazdunski, A. M., Ventre, I., \& Sturgis, J. N. (2004) Regulatory circuits and communication in Gram-negative bacteria. Nat Rev Micro 2: 581-592.

Manefield, M. (1999) Evidence that halogenated furanones from Delisea pulchra inhibit acylated homoserine lactone (AHL)-mediated gene expression by displacing the AHL signal from its receptor protein. Microbiol 145: 283.

McClean, K. H., Winson, M. K., Fish, L., Taylor, A., Chhabra, S. R., Camara, M. et al. (1997) Quorum sensing and Chromobacterium violaceum: exploitation of violacein production and inhibition for the detection of $\mathrm{N}$-acylhomoserine lactones.

Microbiology 143: 3703.

McLean, R. J. C., Whiteley, M., Stickler, D. J., \& Fuqua, W. C. (1997) Evidence of autoinducer activity in naturally occurring biofilms. FEMS Microbiol Lett 154: 259263.

Miller, M. B., \& Bassler, B. L. (2001) Quorum sensing in bacteria. Annu Rev Microbiol 55: $165-199$.

Mohamed, N. M., Cicirelli, E. M., Kan, J. J., Chen, F., Fuqua, C., \& Hill, R. T. (2008) Diversity and quorum-sensing signal production of Proteobacteria associated with marine sponges. Environ Microbiol 10: 75-86.

Morin, D., Grasland, B., Vallee-Rehel, K., Dufau, C., \& Haras, D. (2003) On-line highperformance liquid chromatography-mass spectrometric detection and quantification of $\mathrm{N}$-acylhomoserine lactones, quorum sensing signal molecules, in the presence of biological matrices. J Chromatogr A 1002: 79-92. 
Nakashima, T., Miyazaki, Y., Matsuyama, Y., Muraoka, W., Yamaguchi, K., \& Oda, T. (2006) Producing mechanism of an algicidal compound against red tide phytoplankton in a marine bacterium $\gamma$-proteobacterium. Appl Microbiol Biot 73: 684.

Nealson, K. H., Platt, T., \& Hastings, J. W. (1970) Cellular control of the synthesis and activity of the bacterial luminescent system. J Bacteriol 104: 313-322.

Nealson, K. H., \& Hastings, J. W. (2006) Quorum sensing on a global scale: Massive numbers of bioluminescent bacteria make Milky Seas. Appl Environ Microbiol 72: 2295-2297.

Novick, R. P., \& Muir, T. W. (1999) Virulence gene regulation by peptides in Staphylococci and other Gram-positive bacteria. Curr Opin Microbiol 2: 40-45.

Onaka, H., Ando, N., Nihira, T., Yamada, Y., Beppu, T., \& Horinouchi, S. (1995) Cloning and characterization of the A-factor receptor gene from Streptomyces griseus. J Bacteriol 177: 6083-6092.

Ortori, C. A., Atkinson, S., Chhabra, S. R., Camara, M., Williams, P., \& Barrett, D. A. (2007) Comprehensive profiling of N-acylhomoserine lactones produced by Yersinia pseudotuberculosis using liquid chromatography coupled to hybrid quadrupolelinear ion trap mass spectrometry. Anal Bioanal Chem 387: 497-511.

Paggi, R. A., Martone, C. B., Fuqua, C., \& Castro, R. E. (2003) Detection of quorum sensing signals in the haloalkaliphilic archaeon Natronococcus occultus. FEMS Microbiol Lett 221: 49-52.

Pasmore, M., \& Costerton, J. W. (2003) Biofilms, bacterial signaling, and their ties to marine biology. J Ind Microbiol Biot 30: 407-413.

Pesci, E., Milbank, J., Pearson, J., McKnight, S., Kende, A., Greenberg, E., \& Iglewski, B. (1999) Quinolone signaling in the cell-to-cell communication system of Pseudomonas aeruginosa. PNAS 96: 11229-11234.

Ravn, L., Christensen, A. B., Molin, S., Givskov, M., \& Gram, L. (2001) Methods for detecting acylated homoserine lactones produced by Gram-negative bacteria and their application in studies of AHL-production kinetics. J Microbiol Meth 44: 239251.

Redfield, R. J. (2002) Is quorum sensing a side effect of diffusion sensing? Trends Microbiol 10: 365-370. 
Romero, M. (2010) Acyl homoserine lactone production and degradation by the fish pathogen Tenacibaculum maritimum, a member of the Cytophaga-FlavobacteriumBacteroides (CFB) group. FEMS Microbiol Lett 304: 131.

Ruby, E. G., \& Lee, K. H. (1998) The Vibrio fischeri-Euprymna scolopes light organ association: current ecological paradigms. Appl Environ Microbiol 64: 805.

Rusch, D. B., Halpern, A. L., Sutton, G., Heidelberg, K. B., Williamson, S., Yooseph, S. et al. (2007) The Sorcerer II global ocean sampling expedition: Northwest Atlantic through eastern tropical Pacific. PLoS Biol 5: e77.

Sauer, K., \& Camper, A. K. (2001) Characterization of phenotypic changes in Pseudomonas putida in response to surface-associated growth. J Bacteriol 183: 6579-6589.

Schaefer, A. L., Greenberg, E., Oliver, C. M., Oda, Y., Huang, J. J., Bittan-Banin, G. et al. (2008) A new class of homoserine lactone quorum-sensing signals. Nature 454: 595-599.

Schaefer, A. L., Greenberg, E. P., \& Parsek, M. R. (2001) Acylated homoserine lactone detection in Pseudomonas aeruginosa biofilms by radiolabel assay. Method Enzymol 336: 41-47.

Sharif, D. I., Gallon, J., \& Smith, C. J. (2008) Quorum sensing in Cyanobacteria: Noctanoyl-homoserine lactone release and response, by the epilithic colonial cyanobacterium Gloeothece PCC6909. ISME J 2: 1171-1182.

Shaw, P. D., Ping, G., Daly, S. L., Cha, C., Cronan, J. E., Rinehart, K. L., \& Farrand, S. K. (1997) Detecting and characterizing N-acyl-homoserine lactone signal molecules by thin-layer chromatography. PNAS 94: 6036-6041.

Singh, P. K., Schaefer, A. L., Parsek, M. R., Moninger, T. O., Welsh, M. J., \& Greenberg, E. P. (2000) Quorum-sensing signals indicate that cystic fibrosis lungs are infected with bacterial biofilms. Nature 407: 762-4.

Smith, D. C., Steward, G. F., Long, R. A., \& Azam, F. (1995) Bacterial mediation of carbon fluxes during a diatom bloom in a mesocosm. Deep-Sea Res II 42: 75-97.

Steindler, L., \& Venturi, V. (2007) Detection of quorum-sensing N-acyl homoserine lactone signal molecules by bacterial biosensors. FEMS Microbiology Letters 266: $1-9$. 
T. R. I. Cataldi, G. Bianco, M. Frommberger, Ph. Schmitt-Kopplin. (2004) Direct analysis of selected $N$-acyl-L-homoserine lactones by gas chromatography/mass spectrometry. Rapid Commun Mass Spectrom 18: 1341-1344.

Tait, K., Hutchison, Z., Thompson, F. L., \& Munn, C. B. (2010) Quorum sensing signal production and inhibition by coral-associated vibrios. Environ Microbiol Rep 2: 145150.

Tait, K., Joint, I., Daykin, M., Milton, D. L., Williams, P., \& Camara, M. (2005) Disruption of quorum sensing in seawater abolishes attraction of zoospores of the green alga Ulva to bacterial biofilms. Environ Microbiol 7: 229-240.

Taylor, M. W., Schupp, P. J., Baillie, H. J., Charlton, T. S., de Nys, R., Kjelleberg, S., \& Steinberg, P. D. (2004) Evidence for acyl homoserine lactone signal production in bacteria associated with marine sponges. Appl Environ Microb 70: 4387-4389.

Thiel, V., Kunze, B., Verma, P., Wagner-Dçbler, I., \& Schulz, S. (2009) New structural variants of homoserine lactones in bacteria. Chembiochem 10: 1861-1868.

Valle, A., Bailey, M. J., Whiteley, A. S., \& Manefield, M. (2004) N-acyl-1-homoserine lactones (AHLs) affect microbial community composition and function in activated sludge. Environ Microbiol 6: 424-433.

Vetter, Y., Deming, J., Jumars, P., \& Krieger-Brockett, B. (1998) A predictive model of bacterial foraging by means of freely released extracellular enzymes. Microb Ecol 36: $75-92$.

Vroom, J. M., De Grauw, K. J., Gerritsen, H. C., Bradshaw, D. J., Marsh, P. D., Watson, G. K. et al. (1999) Depth penetration and detection of $\mathrm{pH}$ gradients in biofilms by two-photon excitation microscopy. Appl Environ Microbiol 65: 3502-3511.

Wagner-Dobler, I., Thiel, V., Eberl, L., Allgaier, M., Bodor, A., Meyer, S. et al. (2005) Discovery of complex mixtures of novel long-chain quorum sensing signals in freeliving and host-associated marine alphaproteobacteria. Chembiochem 6: 2195-2206.

Wang, Y., \& Leadbetter, J. R. (2005) Rapid acyl-homoserine lactone quorum signal biodegradation in diverse soils. Appl Environ Microbiol 71: 1291-1299.

Waters, C. M., \& Bassler, B. L. (2005) Quorum sensing: cell-to-cell communication in bacteria. Ann Rev Cell Dev Biol 21: 319-346.

Whiteley, M., \& Greenberg, E. P. (2001) Promoter specificity elements in Pseudomonas aeruginosa quorum-sensing-controlled genes. J Bacteriol 183: 5529-5534. 
Winson, M., Camara, M., Latifi, A., Foglino, M., Chhabra, S., Daykin, M. et al. (1995) Multiple N-acyl-L-homoserine lactone signal molecules regulate production of virulence determinants and secondary metabolites in Pseudomonas aeruginosa. Proc Natl Acad Sci U S A 92: 9427.

Yates, E. A., Philipp, B., Buckley, C., Atkinson, S., Chhabra, S. R., Sockett, R. E. et al. (2002) N-Acylhomoserine lactones undergo lactonolysis in a pH-, temperature-, and acyl chain length-dependent manner during growth of Yersinia pseudotuberculosis and Pseudomonas aeruginosa. Infect Immun 70: 5635-5646.

Ziervogel, K., \& Arnosti, C. (2008) Polysaccharide hydrolysis in aggregates and free enzyme activity in aggregate-free seawater from the north-eastern Gulf of Mexico. Environ Microbiol 10: 289-299. 


\title{
CHAPTER 2:
}

\section{KINETIC CONSTRAINTS ON ACYLATED HOMOSERINE LACTONE-BASED QUORUM SENSING IN MARINE ENVIRONMENTS}

\author{
Laura Hmelo and Benjamin A. S. Van Mooy
}

This chapter originally appeared as a manuscript in:

Aquatic Microbial Ecology, 2009, 54 (127-133)

\begin{abstract}
Quorum sensing (QS) via acylated homoserine lactone (AHLs) was discovered in the ocean, yet AHLs are expected to be very short-lived at seawater $\mathrm{pH}$ due to rapid abiotic degradation. Quorum quenching, the enzymatic degradation of AHLs, is also likely. To better understand the potential for QS to regulate behaviors of marine bacteria we investigated the degradation of a variety of AHL molecules in several types of saltwater media. We did this by incubating AHLs and tracking their concentration using high performance liquid chromatography / electrospray-ionization mass-spectrometry (HPLC/ESI-MS). AHL concentrations decreased with time, and degradation rate coefficients were calculated by applying a first-order rate law. The rate of abiotic degradation showed strong dependence on acyl-chain length and the presence of 3-oxo substitutions on the acyl-chain. We found that the rate of abiotic degradation of AHLs in
\end{abstract}


artificial seawater was much slower than that predicted by an oft-cited equation that takes only $\mathrm{pH}$ into account. However, AHLs degraded more rapidly in natural seawater than in artificial seawater, an observation we found to be due to quorum quenching enzyme activity. By applying calculated degradation rates in a simple steady-state calculation, we suggest that despite the observed quorum quenching activity, AHLs are likely to be viable signals in organic particles and in other microbial "hotpsots" in marine environments.

\section{INTRODUCTION}

The first description of bacterial quorum sensing (QS) arose from studies of the marine luminescent bacterium Vibrio fischeri which colonizes the light organs of eukaryotic hosts, most famously, the Hawaiian bobtail squid (Euprymna scalopies) (Coffey 1967, Eberhard et al. 1981) . V. fischeri's QS system was found to be regulated by acylated homoserine lactones (AHLs), and AHL-based QS has been subsequently identified in numerous isolates of marine Proteobacteria (e.g. Eberhard et al. 1981, Gram et al. 2002, Wagner-Dobler et al. 2005). Since Proteobacteria often dominate marine microbial communities (Giovannoni \& Rappe 2000), AHL-based QS has the potential to be widespread in the sea. For example, Miller et al. (2005) invoked QS-induced bacterial luminescence to explain a "milky sea" event where a 15,400 $\mathrm{km}^{2}$ patch of the Arabian Sea was observed by satellite to glow for several days. These authors speculated that the light was produced by a dramatic increase in the local concentration of the luminescent bacterium $V$. harveyi in response to resources supplied by a coincident algal bloom. 
In addition to luminescence, AHLs have been shown to regulate a number of potentially ecologically relevant phenotypes; these include siderophore production, hydrolytic enzyme activity and biofilm formation (Miller \& Bassler 2001 and refs therein). These behaviors could play an important role in the degradation of sinking organic matter in the ocean, and since AHL-producing bacteria were first isolated from marine snow by Gram et al (2002) QS has been increasing implicated as a potentially significant process in the marine carbon cycle (e.g. Buchan et al. 2005, Ziervogel \& Arnosti 2008).

AHLs are not only signals for bacterial communication; they can also mediate the settlement of eukaryotic larvae on bacterial biofilms (Joint et al. 2002, Tait et al. 2005). Larvae have been shown to use the presence or absence of AHLs to determine the suitability of a surface for permanent settlement (Joint et al. 2002, Tait et al. 2005). AHL production in biofilms thus plays a role in the ecology of higher organisms and in the biofouling of submerged surfaces (e.g. shiphulls).

AHLs are active as QS-signals only in their intact, lactone-based form, and the lactone moiety of AHLs is highly susceptible to rapid, base-catalyzed abiotic degradation (Yates et al. 2002). It has been shown that AHLs are very short-lived in aqueous media with $\mathrm{pH}$ in the range of seawater (Yates et al. 2002). Furthermore, it appears that AHLs are also degraded enzymatically in natural systems (Delalande et al. 2005, Wang \& Leadbetter 2005), a process that has been termed "quorum quenching".

Taxonomic and functional specificity of AHLs is conferred by the length, degree of unsaturation, and presence or absence of oxo- and hydroxyl-substitution on the acyl 
chain. Multiple AHLs may be used by the same organism to regulate independent processes (Gonzalez \& Marketon 2003 and refs therein). Importantly, the rate of both abiotic degradation and quorum quenching also appears to be affected by these aforementioned variations in AHL structure (Yates et al. 2002, Delalande et al. 2005, Wang \& Leadbetter 2005). It is likely, although not demonstrated, that organisms will produce a particular suite of AHLs based on each molecule's stability in a given environment.

In this study, we sought to quantify the rates of abiotic and enzymatic AHL degradation in seawater and to gain a better understanding of the conditions that must be met in order for AHL-based QS to take place in marine environments. To do this, we used high performance liquid chromatography / electrospray-ionization massspectrometry (HPLC/ESI-MS) to track the degradation of intact, biologically active AHLs in a number of seawater incubation experiments. Even though QS research owes its provenance to the study of marine bacteria, there have been few previous investigations of the stability of AHLs under natural seawater conditions (Tait et al., 2005).

\section{METHODS}

A note on nomenclature: We abbreviate the names of specific AHLs as:(3O)C(n)-HSL where $n$ refers to length of acyl side chain bound to homoserine lactone (HSL) and 30 indicates the presence of a 3-'oxo'(ketone) group on the acyl-side chain (Fig. 1). 


\section{Incubation design}

Rates of AHL degradation were determined by incubating synthetic AHLs in defined liquid media and tracking their concentrations by HPLC/ESI-MS. Synthetic C4-, 3OC6-, C6-, C7-, 3OC8-, C8- and C12-HSL were purchased from Sigma-Aldrich and individual solutions were made with HPLC-grade methanol to a concentration of $500 \mu \mathrm{mol} \mathrm{L}^{-1}$. A $30 \mu \mathrm{L}$ aliquot of a standard was added to the bottom of a pre-combusted $40 \mathrm{~mL}$ clear glass vial, and the methanol was allowed to evaporate from the bottom of the vial. Next, $30 \mathrm{~mL}$ of liquid incubation media (defined below) was added. The vials were then sealed with UV-sterilized PTFE (Teflon) lined caps and incubated on the lab bench. All incubations were conducted at room temperature (approximately $23^{\circ} \mathrm{C}$ ). The final $\mathrm{AHL}$ concentration at the start of all experiments was $500 \mathrm{nmol} \mathrm{L}^{-1}$; this value is comparable to the range of AHL concentrations observed in culture media and measured in the light organs of Euprymna scolopes and Euprymna morsei $\left(0.4-400\right.$ nmol L $\left.{ }^{-1}\right)($ Kaplan \& Greenberg 1985, Schaefer et al. 2002, Burton et al. 2005). All incubations were conducted such that triplicate incubations could be sacrificed at each time point for AHL extraction, analysis, and quantification.

\section{Extraction and analysis of AHLs}

Incubations were extracted three times with $13 \mathrm{~mL}$ dichloromethane (Fisher Scientific). Immediately prior to extraction, $10 \mu \mathrm{L}$ of $500 \mu \mathrm{mol} \mathrm{L}^{-1} \mathrm{Z}$-homoserine lactone (SigmaAldrich) was added to the aqueous phase as an internal standard. The combined extracts were passed through a column of combusted sodium sulfate to remove residual water and 
then dried under nitrogen. Extracts were transferred in methanol to small glass vials for analysis on a Thermo Finnegan Surveyor HPLC coupled to a Thermo-Finnegan LCQ Deca-XP Mass Spectrometer through an electrospray ionization interface. Separation of AHLs was achieved by running a water-methanol gradient through an Altima HP C18 reverse-phase chromatography column (Agilent; $5 \mu \mathrm{m}, 2.1 \times 150 \mathrm{~mm}$ ) with guard column. Solvent A was MilliQ water (0.1\% formic acid) and solvent B was methanol $(0.1 \%$ formic acid). The gradient program was as follows: 0-25 min, gradient from 90\% A/ $10 \% \mathrm{~B}$ to $100 \% \mathrm{~B} ; 25-26 \mathrm{~min}, 100 \% \mathrm{~B} ; 26-27 \mathrm{~min}$, gradient to $90 \% \mathrm{~A} / 10 \% \mathrm{~B} ; 27-36 \mathrm{~min}$ 90\% A/ 10\% B (column equilibration). Intact AHLs have masses, fragmentation patterns, and chromatographic properties that are distinct from their degradation products (data not shown), and the peak areas of the molecular ions from intact the AHLs (Fig. 1) were integrated and converted to concentration units based on the recovery of the internal standard and comparison to standard curves. Standard curves were prepared daily with a fresh mixture of AHLs, and the standard mixture was reanalyzed after every sixth sample.

\section{Incubation media}

All liquid incubation media were prepared immediately prior to their use in the AHL degradation incubations. Whole seawater for all incubation experiments was collected in March 2008 from Vineyard Sound, Massachusetts (41 $\left.{ }^{\circ} 32^{\prime} \mathrm{N}, 70^{\circ} 40^{\prime} \mathrm{W}\right)$ and was filtered in the field through a coarse $(100 \mu \mathrm{m})$ mesh filter to remove seaweed and large particulates. Shortly thereafter in the laboratory, the seawater was filtered through a 0.22 
$\mu \mathrm{m}$ cellulose acetate bottle top filter (Corning) under 200 mbar vacuum, and the $\mathrm{pH}$ determined (see results).

Artificial seawater was prepared using $18 \mathrm{M} \Omega$ MilliQ water according to the Trace MBL artificial seawater recipe $\left(423 \mathrm{mmol} \mathrm{L}^{-1} \mathrm{NaCl}, 8.27 \mathrm{mmol} \mathrm{L}^{-1} \mathrm{KCl}, 9.27 \mathrm{mmol} \mathrm{L}^{-1}\right.$ $\mathrm{CaCl}_{2}, 22.94 \mathrm{mmol} \mathrm{L}^{-1} \mathrm{MgCl}_{2}, 25.50 \mathrm{mmol} \mathrm{L}^{-1} \mathrm{MgSO}_{4}, 2.14 \mathrm{mmol} \mathrm{L}^{-1} \mathrm{NaHCO}_{3}, 0.23$ mmol L $\left.{ }^{-1} \mathrm{SrCl}_{2} .0 .07 \mathrm{mmol} \mathrm{L}^{-1} \mathrm{NaF}, 0.39 \mathrm{mmol} \mathrm{L}^{-1} \mathrm{H}_{3} \mathrm{BO}_{3}, 0.75 \mathrm{mmol} \mathrm{L}^{-1} \mathrm{KBr}\right)$. The artificial seawater was filtered through a $0.22 \mu \mathrm{m}$ cellulose acetate bottle top filter (Corning) under 200 mbar vacuum, and the $\mathrm{pH}$ adjusted to that of Vineyard Sound seawater prior to being used in the degradation experiments by adding small quantities of $1 \mathrm{~mol} \mathrm{~L}^{-1} \mathrm{HCl}$ and $1 \mathrm{~mol} \mathrm{~L}^{-1} \mathrm{NaOH}$ as required.

To assess the impact of enzymes on the degradation of AHLs in Vineyard Sound seawater, endogenous enzymes were denatured either by treating it with $40 \mu \mathrm{g} \mathrm{L}^{-1}$ proteinase-K (Fisher) and incubating at $37^{\circ} \mathrm{C}$ for one hour or by boiling the seawater for 10 minutes. The $\mathrm{pH}$ of these treated seawater media was also measured and adjusted to pH 7.9. 


\section{Data Analysis}

The decrease in the concentrations of these molecules with time was modeled using the first-order rate law equation:

$\operatorname{Ln} \frac{C}{C_{o}}=-k t$

Where, $\mathrm{C}$ is the concentration at a given time point, $\mathrm{C}_{\mathrm{o}}$ is the concentration at time zero, $\mathrm{t}$ is the length of the incubation (hr) and $\mathrm{k}$ is the rate coefficient $\left(\mathrm{hr}^{-1}\right)$. Data when plotted in this manner will fall in a straight line if the reaction kinetics are first order; the rate coefficient is the negative slope of the line and is reported \pm the standard error of the slope. We estimate that two slopes from two sets of degradation experiments are different from one another when their difference is greater than twice the combined standard error of the two slopes.

Incubations with C6-HSL and 3OC6-HSL were conducted such that they could be sampled at five time points. First order kinetics were established for both C6-HSL (Fig. 2) and 3OC6-HSL. Subsequently, only two time points were measured and used to determine degradation coefficients of the other AHLs.

\section{RESULTS}

The AHLs C6- and 3OC6-HSL are the archetypal AHLs from vibrios and are common in many other QS Proteobacteria (Miller \& Bassler 2001); our study focused primarily on these two molecules. In our incubation experiments, all of which were conducted at a $\mathrm{pH}$ of 7.9 (the $\mathrm{pH}$ of Vineyard Sound seawater), we found that the concentrations of these 
AHLs decreased with time according to first order degradation kinetics in natural and artificial media (Fig. 2). Loss of AHLs by first order kinetics was observed whether the AHL was incubated under abiotic conditions (artificial seawater) or in natural seawater from Vineyard Sound, Massachusetts (filtered through $0.2 \mu \mathrm{m}$ poresize membrane).

The degradation rate coefficient of C6-HSL in natural seawater was $0.043 \pm 0.003$ $\mathrm{hr}^{-1}$, and this rate is significantly faster than the rate we observed in artificial seawater, which was $0.028 \pm 0.001 \mathrm{hr}^{-1}$ (Fig. 3). Likewise, 3OC6-HSL degraded at a rate of 0.116 $\pm 0.005 \mathrm{hr}^{-1}$ in natural seawater, which was more rapid than the $0.094 \pm 0.002 \mathrm{hr}^{-1}$ observed in artificial seawater (Fig. 3). Similar observations were made for 3OC8-HSL (Fig. 3). Regardless of media, the oxo-substituted AHLs (3OC6-and 3OC8-HSL) degraded at least twice as fast as that of C6-HSL.

We pretreated natural seawater with proteinase-K to digest endogenous enzymatic proteins and found that this slowed the degradation of C6-, 3OC6-, and 3OC8-HSL relative to that in untreated filtered seawater (Fig. 3). The degradation rate coefficients in proteinase-K treated natural seawater were $0.032 \pm 0.001,0.102 \pm 0.003,0.102 \pm 0.004$ $\mathrm{hr}^{-1}$ for C6-, 3OC6- and 3OC8-HSL respectively and were indistinguishable from the rates observed in artificial seawater. We performed a similar experiment by heat-treating the natural seawater and the degradation coefficients also decreased to $0.034 \pm 0.002$, $0.089 \pm 0.2$, and $0.087 \pm 0.01 \mathrm{hr}^{-1}$, respectively

The degradation rate coefficients of C4-, C7-, and C8-, and C12-HSLs were also measured in natural and artificial seawater. We observed a chain-length dependence amongst straight-chain AHLs such that longer-chain AHLs degrade more slowly than 
shorter chain AHLs (Fig. 4). This relationship did not appear to hold for 3-oxo substituted AHLs, although only two molecules of this type were examined.

We assessed the potential impact of abiotic sorption of AHLs to the glass walls of the incubation vials; this was done in incubations of C6-HSL and 3OC6-HSL conducted with different volumes of water but in the same $40 \mathrm{~mL}$ vials. By doing this, we affected a 5-fold difference in the surface area to volume ratio of the incubations, but observed no measurable differences in degradation rate coefficients. Thus, surface sorption did not impact the observed rates of AHL degradation and will not be further discussed.

\section{DISCUSSION}

The effect of $\mathrm{pH}$ on the abiotic degradation of AHLs in aqueous media (LB media, organic buffers or pure water) is well established: AHLs degrade more rapidly at higher pH (Yates et al. 2002, Delalande et al. 2005). In seawater, with an average pH of 8.2, AHLs are expected to degrade quite rapidly. However, to our knowledge, the degradation rates of AHLs in seawater have yet to be explicitly determined. In this study, we focused our attention on the understanding the effects of both abiotic degradation and quorum quenching enzyme activity on AHL degradation in natural seawater collected from Vineyard Sound, Massachusetts.

In artificial seawater, only abiotic factors influenced the degradation of AHLs. Both unsubstituted and 3-oxo substituted AHLs are highly susceptible to degradation by base-catalyzed abiotic lactonolysis (Yates et al., 2002). In addition, 3-oxo substituted AHLs may degrade via an abiotic Claisen-like rearrangement (Kaufmann et al. 2005). 
Accordingly, 3OC6- -HSL degraded significantly faster than C6-HSL in artificial seawater and all natural seawater-based media we tested (Fig. 3). However, we observed that 3OC6-HSL degrades much more slowly in artificial seawater, $\left(0.094 \pm 0.002 \mathrm{hr}^{-1}\right)$ than the rate predicted by the $\mathrm{pH}$-dependent formula $\left(0.26 \mathrm{hr}^{-1}\right)$ of Schaffer et al (2000), which is often cited (e.g. Wang and Leadbetter, 2005). This suggests that AHL degradation may occur more slowly in saltwater relative to other aqueous media.

In contrast, AHLs in natural seawater are subject to the above abiotic degradation mechanisms as well as attack from quorum quenching enzymes. In natural seawater the degradation rate coefficients of C6-, 3OC6-3OC8-HSL were 54, 23 and 57\% faster respectively than in artificial seawater and we assert that this difference was due to quorum quenching activity. Evidence for this assertion comes from the observation that the denaturation of endogenous proteins in natural seawater decreased the rates of AHL degradation such that they were indistinguishable from artificial seawater, which confirms that at significant fraction of the observed quorum quenching activity was due to free enzymatic proteins.

Our observations of quorum quenching activity in seawater is striking since it suggests that the marine microbiota in Vineyard Sound have invested in enzymes to accelerate the degradation of AHL molecules that are already relatively short-lived in seawater due to abiotic degradation processes. Alternatively, the AHLs may have been degraded by non-specific enzyme activity, which suggests that quorum quenching is not the result of a specific strategy directed at disrupting QS systems but is merely the fortuitous result of entirely unrelated enzyme activity. Our observation of active quorum 
quenching in natural seawater outside of biofilms, suggests that this process could place important constraints on the role AHLs in eukaryotic larval recruitment under natural conditions.

In this study, short-chain AHLs degraded more rapidly than long-chain AHLs in both artificial seawater and filtered natural seawater. This result is consistent with previous studies in freshwater media showing that AHLs with shorter acyl chains are shorter-lived (Yates et al. 2002) Longer chain AHLs may be better optimized to function in a seawater medium due to their longer half-life with respect to abiotic degradation. This inference is consistent with numerous reports that AHL-producing marine bacterial isolates often produce long chain AHLs rather than short chain AHLs (Schaefer et al. 2002, Wagner-Dobler et al. 2005). On the other hand, bacteria in marine environments could use AHLs with shorter acyl chains to communicate over relatively shorter distances. Yet organisms using shorter chains AHLs would be required to synthesize them at a greater rate to achieve a given concentration in the environment.

Using our measured rate coefficient for 3OC6-HSL degradation in natural Vineyard Sound seawater as an example, we can make a steady state estimate of the rate of production required to maintain 3OC6-HSL at concentrations sufficient for the induction of bacterial QS systems in marine environments. We attempted to measure AHLs directly in natural seawater from Vineyard Sound, but found that levels were below our analytical limit of detection of approximately $10 \mathrm{pmol} \mathrm{L}^{-1}$. QS systems in Proteobacteria are generally not induced until AHL concentrations reach at least $10 \mathrm{nmol}$ $\mathrm{L}^{-1}$ (Kaplan \& Greenberg 1985), which is three orders of magnitude higher than our 
detection limit; this suggests that AHL-regulated behaviors are very unlikely to be active in open seawater. However, if we assume the required concentration of 3OC6-HSL in seawater is indeed $10 \mathrm{nmol} \mathrm{L}^{-1}$, then we can calculate the maximum first-order molar degradation rate of this AHL as simply the product of this concentration and the degradation rate coefficient $(\mathrm{k})$ we measured:

Degradation rate $=\mathrm{k}[3 \mathrm{OC6}-\mathrm{HSL}]=0.11 \mathrm{hr}^{-1} \mathrm{x} 10 \mathrm{nmol} \mathrm{L}^{-1} \approx 1.1 \mathrm{nmol} \mathrm{L}^{-1} \mathrm{hr}^{-1}$

At steady state, the degradation rate this AHL would be equal to its production rate.

Using the 3OC6-HSL production rate the required density of AHL producing bacterial cells can also be estimated. Fully-induced QS Proteobacteria synthesize AHLs at rates on the order of 1 amol cell ${ }^{-1} \mathrm{hr}^{-1}$ (Wang \& Leadbetter 2005) and so at steady state, a minimum of $1.1 \times 10^{9}$ cells $\mathrm{L}^{-1}$ would be required in order for production to match our calculated molar degradation rate. While total cell concentrations in the open ocean may reach these concentrations, for monospecific concentrations to approach this level would require truly exceptional environmental conditions. Obviously, the uncertainty in this estimate could be as high as an order of magnitude. Nonetheless, this analysis suggests, as expected, that QS-thresholds are much more likely to occur in marine biofilms, such as those that occur on sinking particles where total bacterial cell concentrations in excess of $10^{11}$ cells $\mathrm{L}^{-1}$ are possible. These and other microbial "hotspots" play a significant role in the marine carbon cycle (Azam et al., 1998, and refs therein). 
The rates of AHL degradation we determined in this study enabled us to make an estimate of the concentration of bacteria required to induce QS behaviors in natural marine systems. Our data do not preclude a planktonic bacterial origin for the largescale 'milky sea' reported by Miller et al (2005), but they do put minimum constraints on planktonic population densities that would be required for QS-induced Proteobacterial luminescence events to occur in the open ocean.

Acknowledgements. We gratefully acknowledge the assistance of H. Fredricks with maintenance and method development pertaining to the HPLC-MS. We also thank E. DeLong and C. Reddy for helpful conversations. This work was funded by a grant from the Office of Naval Research to B.V.M. (N0014-06-1-0134), and an NSF Graduate Student Fellowship to L.H. 


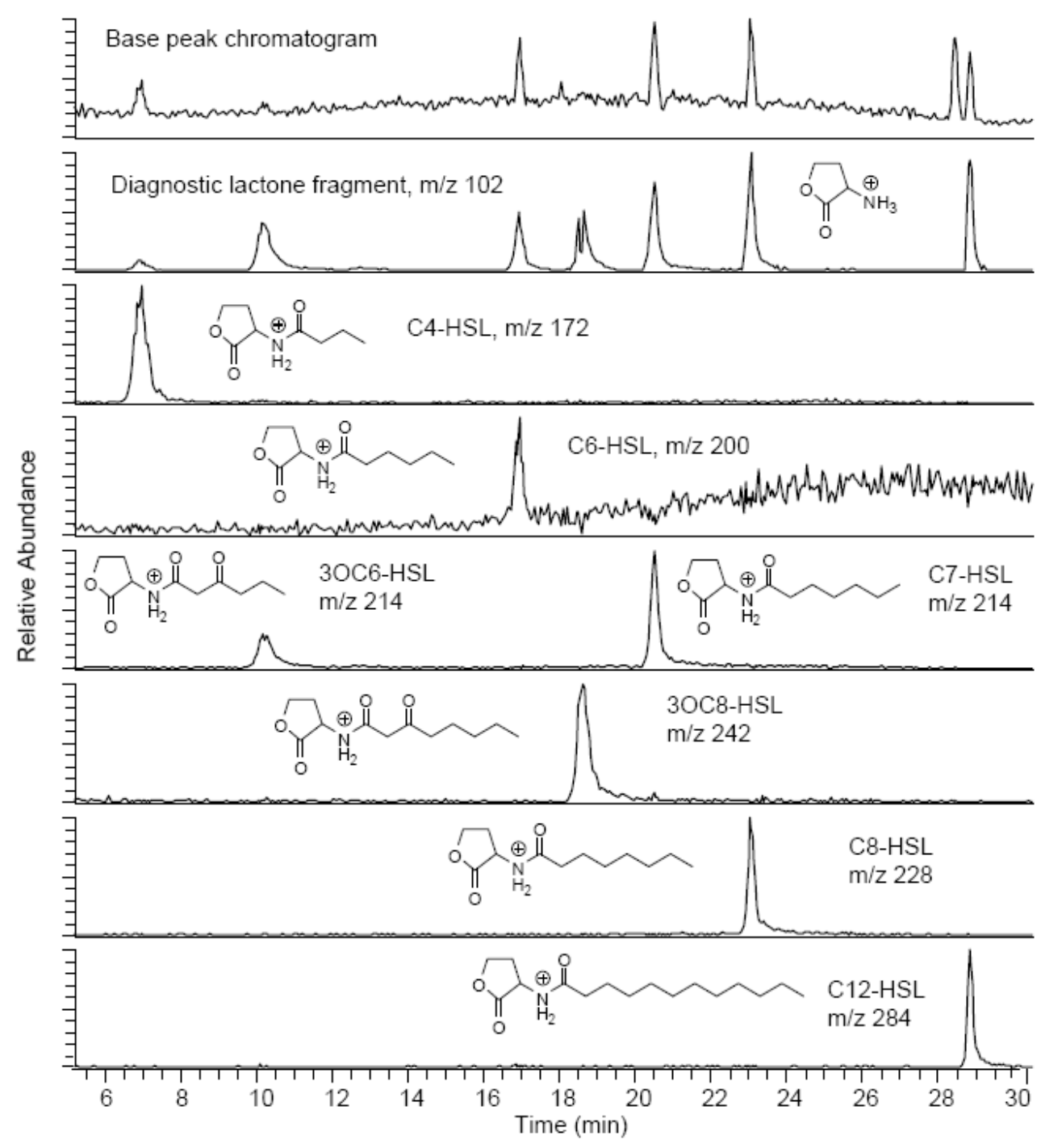

Figure 1. Extracted ion chromatograms from HPLC/ESI-MS analysis of AHLs used in this study. Molecular structures of C4-, 3OC6-, C6-, C7-, 3OC8-, C8-, and C12-HSL are inset next to respective the chromatogram . The names of specific AHLs are abbreviated as:(3O)C(n)-HSL where $\mathrm{n}$ refers to length of acyl side chain bound to homoserine lactone (HSL) and $3 \mathrm{O}$ indicates the presence of a 3-'oxo'(ketone) substituent on the acylside chain. 


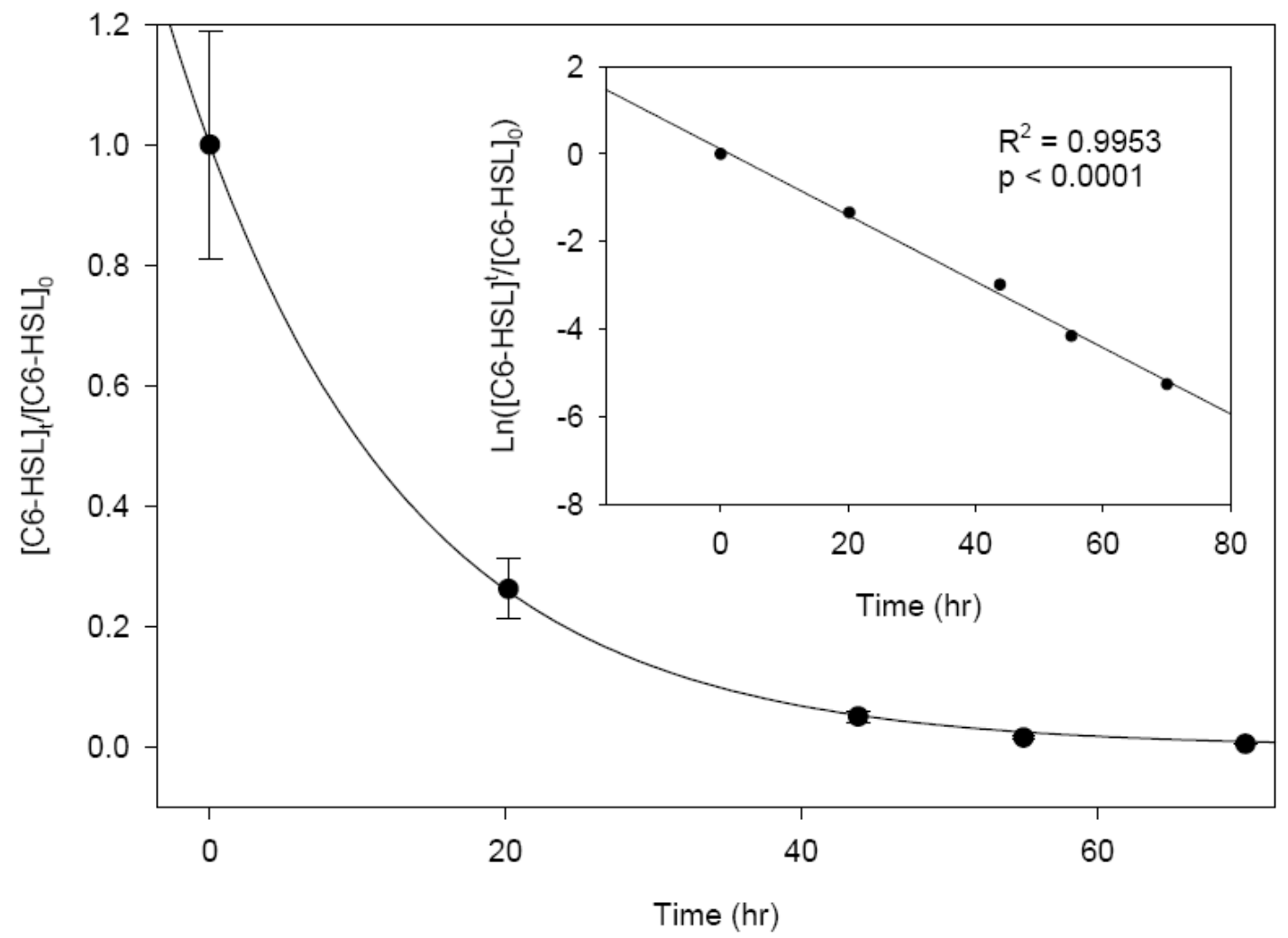

Figure 2. Plot of C6-HSL concentration over time during incubation in seawater from Vineyard Sound, Massachusetts. The inset is the natural logarithm transformed data as applied in Equation 1. 

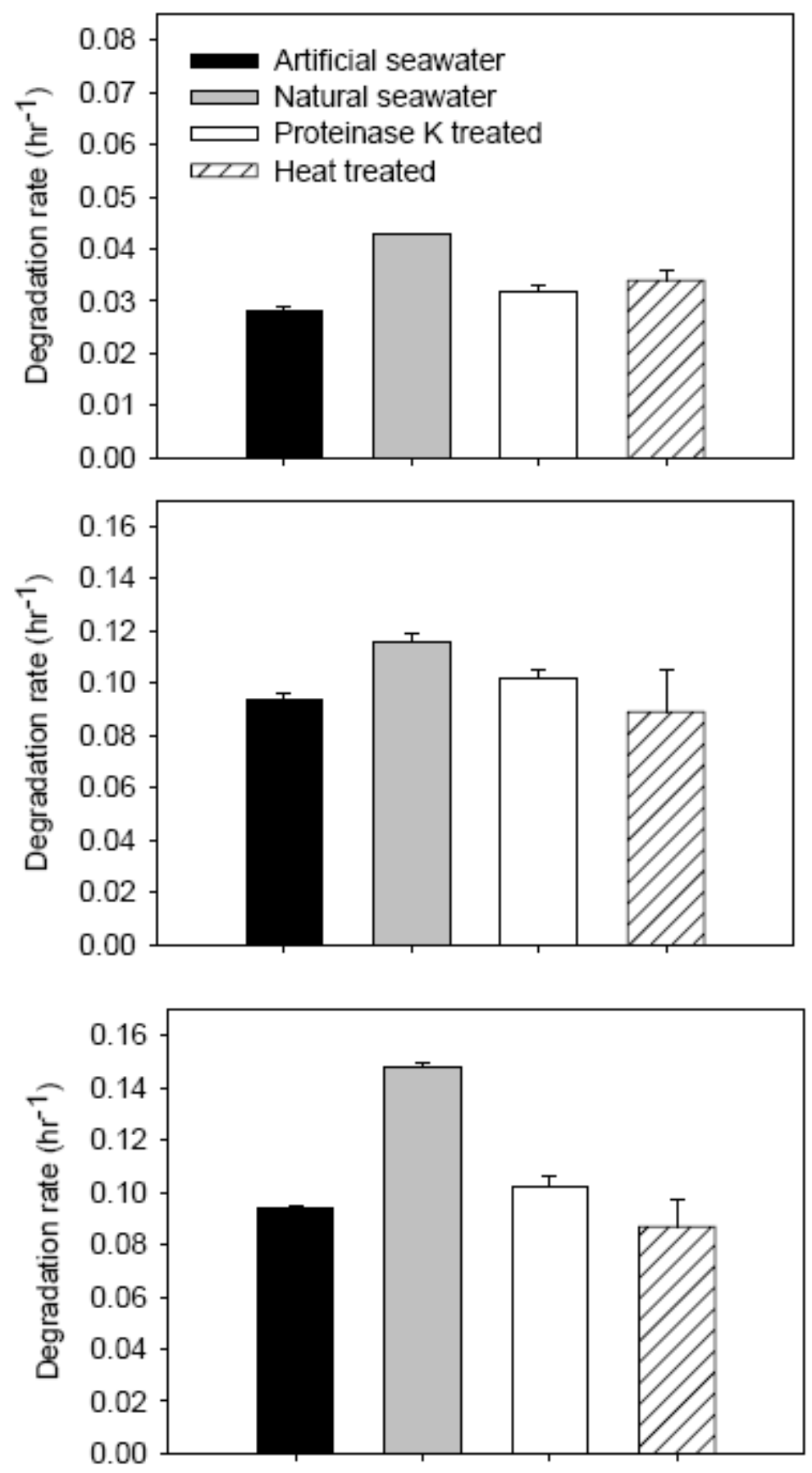

Figure 3. Degradation rate coefficients of C6-HSL (top), 3OC6-HSL (middle) and 3OC8-HSL (bottom) in artificial seawater, natural seawater, proteinase $\mathrm{K}$ treated natural seawater, and heat-treated natural seawater. 


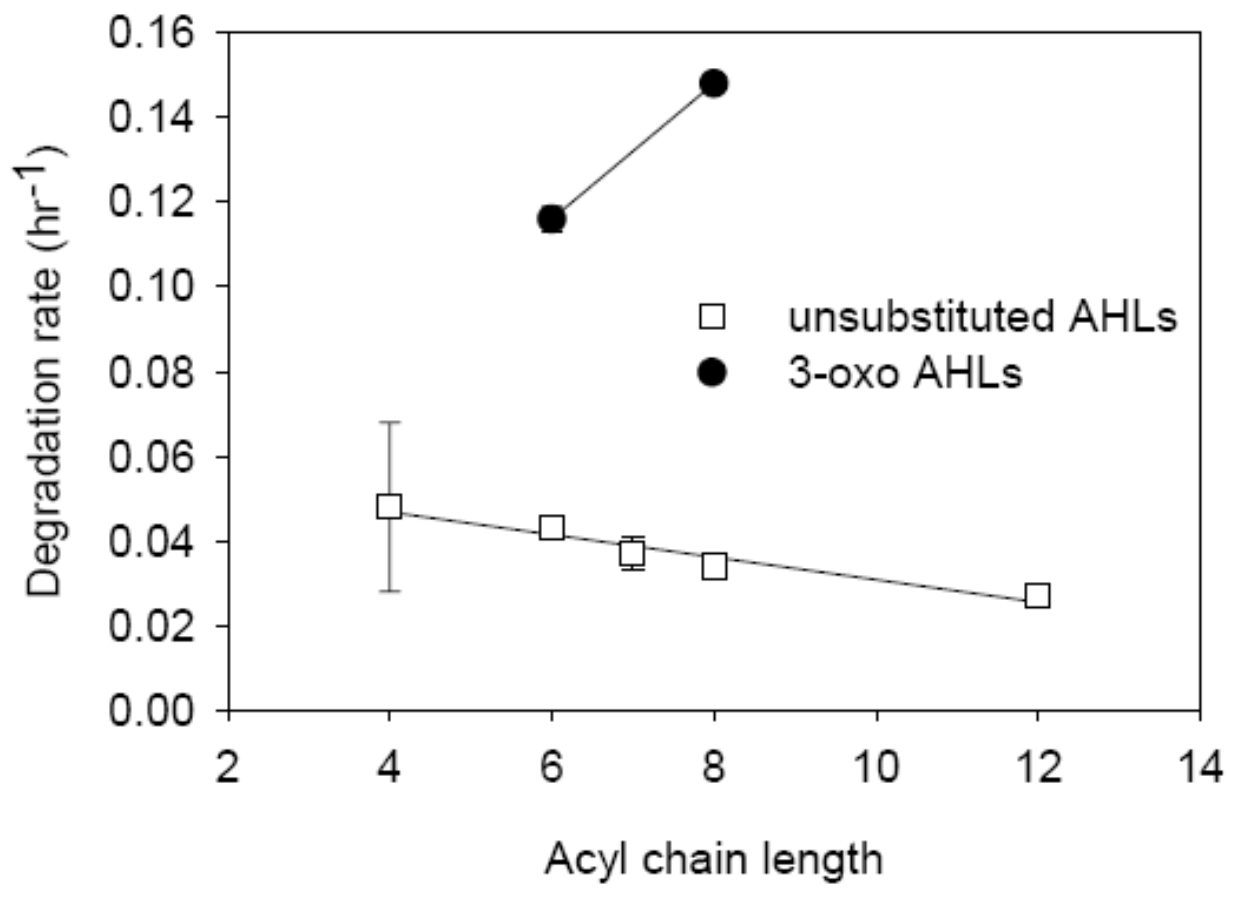

Figure 4. Plot of the degradation rate coefficients of various AHLs in $0.22 \mu \mathrm{m}$ filtered seawater versus the length of the acyl-side chain. 


\section{REFERENCES}

Buchan A, González JM, Heidelberg JF, Whitman WB, Kiene RP, Henriksen JR, King GM, Belas R, Fuqua C, Brinkac L (2005) Genome sequence of Silicibacter pomeroyi reveals adaptations to the marine environment. Nature 432:910-913

Burton EO, Read HW, Pellitteri MC, Hickey WJ (2005) Identification of AcylHomoserine Lactone Signal Molecules Produced by Nitrosomonas europaea Strain Schmidt. Appl Environ Microb 71:4906-4909

Coffey JJ (1967) Inducible synthesis of bacterial luciferase: Specificity and kinetics of induction. J Bacteriol 94:1638-1647

Delalande L, Faure D, Raffoux A, Uroz S, D'Angelo-Picard C, Elasri M, Carlier A, Berruyer R, Petit A, Williams P, Dessaux Y (2005) N-hexanoyl-1-homoserine lactone, a mediator of bacterial quorum-sensing regulation, exhibits plantdependent stability and may be inactivated by germinating Lotus corniculatus seedlings. FEMS Microbiol Ecol 52:13-20

Eberhard A, Burlingame A, Eberhard C, Kenyon G, Nealson K, Oppenheimer N (1981) Structural identification of autoinducer of Photobacterium fischeri luciferase. Biochemistry 20:2444-2449

Giovannoni SJ, Rappe MS (2000) Evolution, diversity, and molecular ecology of marine prokaryotes. In: Kirchman DL (ed) Microbial Ecology of the Oceans. Wiley-Liss, New York

Gonzalez JE, Marketon MM (2003) Quorum Sensing in Nitrogen-Fixing Rhizobia. Microbiol Mol Biol R 67:574-592 
Gram L, Grossart H-P, Schlingloff A, Kiorboe T (2002) Possible quorum sensing in marine snow bacteria: Production of acylated homoserine lactones by Roseobacter strains isolated from marine snow. Appl Environ Microb 68:41114116

Joint I, Tait K, Callow ME, Callow JA, Milton D, Williams P, Camara M (2002) Cell-tocell communication across the prokaryote-eukaryote boundary. Science 298:12071207

Kaplan HB, Greenberg EP (1985) Diffusion of autoinducer is involved in regulation of the Vibrio fischeri luminescence system. J Bacteriol 163:1210-1214

Kaufmann GF, Sartorio R, Lee S-H, Rogers CJ, Meijler MM, Moss JA, Clapham B, Brogan AP, Dickerson TJ, Janda KD (2005) Revisiting quorum sensing: Discovery of additional chemical and biological functions for 3-oxo-Nacylhomoserine lactones. PNAS 102:309-314

Miller MB, Bassler BL (2001) Quorum sensing in bacteria. Ann Rev Microbiol 55:165199

Miller SD, Haddock SHD, Elvidge CD, Lee TF (2005) Detection of a bioluminescent milky sea from space. PNAS 102:14181-14184

Schaefer AL, Hanzelka BL, Parsek MR, Greenberg EP (2000) Detection, purification, and structural elucidation of the acylhomoserine lactone inducer of Vibrio fischeri luminescence and other related molecules. In: Methods in Enzymology: Bioluminescence and Chemiluminescence Part C. Academic Press, p 288-301 
Schaefer AL, Taylor TA, Beatty JT, Greenberg EP (2002) Long-Chain Acyl-Homoserine Lactone Quorum-Sensing Regulation of Rhodobacter capsulatus Gene Transfer Agent Production. J Bacteriol 184:6515-6521

Tait K, Joint I, Daykin M, Milton DL, Williams P, Camara M (2005) Disruption of quorum sensing in seawater abolishes attraction of zoospores of the green alga Ulva to bacterial biofilms. Environ Microbiol 7:229-240

Wagner-Dobler I, Thiel V, Eberl L, Allgaier M, Bodor A, Meyer S, Ebner S, Hennig A, Pukall R, Schulz S (2005) Discovery of complex mixtures of novel long-chain quorum sensing signals in free-living and host-associated marine alphaproteobacteria. Chembiochem 6:2195-2206

Wang Y-J, Leadbetter JR (2005) Rapid acyl-homoserine lactone quorum signal biodegradation in diverse soils. Appl Environ Microb 71:1291-1299

Yates EA, Philipp B, Buckley C, Atkinson S, Chhabra SR, Sockett RE, Goldner M, Dessaux Y, Camara M, Smith H, Williams P (2002) N-Acylhomoserine lactones undergo lactonolysis in a pH-, temperature-, and acyl chain length-dependent manner during growth of Yersinia pseudotuberculosis and Pseudomonas aeruginosa. Infect Immun 70:5635-5646

Ziervogel K, Arnosti C (2008) Polysaccharide hydrolysis in aggregates and free enzyme activity in aggregate-free seawater from the north-eastern Gulf of Mexico. Environ Microbiol 10:289-299 


\title{
CHAPTER 3:
}

\section{COMBINED BIOSENSOR AND HPLC-MS APPROACH TO THE ANALYSIS OF ACYLATED HOMOSERINE LACTONE SIGNALS FROM COMPLEX SAMPLE-MATRICES: APPLICATION TO THE ANALYSIS OF AHLS PRODUCED BY EPIBIONTS OF WILD TRICHODESMIUM SPP.}

\begin{abstract}
Trichodesmium spp. are known to harbor dense epibiont populations, a sizeable percentage of which are related to the Proteobacteria. Proteobacteria are known to utilize quorum sensing (QS) under laboratory conditions and the physical and chemical environment of the Trichodesmium phycosphere should be conducive to efficient QS mediated by the signal, acylated homoserine lactone (AHL). In this study, 142 cultivars were screened for the production of AHLs by use of a broad-spectrum biosensor as well as two different mass spectrometric methods; a comparison of a commonly used lowsensitivity, low-resolution ion trap device and a high-sensitivity, high-resolution device (Fourier transform-ion cyclotron resonance-mass spectrometry, FT-ICR-MS) clearly showed that the FT-ICR-MS is the most appropriate tool for the analysis of AHLs in complex sample matrices. Eight bacterial isolates, of the genus Vibrio and Erythrobacter were determined to produce AHLs although this is likely a lower limit on the diversity and proportion of AHL-producing bacteria in the Trichodesmium phycosphere. This is the first report of AHL-production by an Erythrobacter sp. and highlights the continued
\end{abstract}


importance of cultivation efforts in expanding the landscape of known-AHL producing genera.

\section{INTRODUCTION}

Quorum sensing (QS) is a cell-to-cell communication mechanism used by bacteria to regulate group-beneficial behaviors. It has been extensively studied by biomedical researchers for the role that it plays in human disease. However, QS was originally discovered in the marine environment (Nealson et al., 1970; Eberhard et al., 1981; Kaplan \& Greenberg, 1985), and it is becoming clear that it is involved with important ecological processes and biogeochemical transformations in the ocean (Gram et al., 2002; Buchan et al., 2005; Nealson \& Hastings, 2006; Decho et al., 2009; Hmelo, 2010). The study of QS in the ocean has been hindered by the challenge of extracting detectable quantities of labile, low-concentration signal molecules from the complex mixture of biochemicals in seawater.

Marine bacterial communities contain large numbers of Proteobacteria (greater than $50 \%$ of total populations (Rusch et al., 2007)). Many of these bacteria use acylated homoserine lactones (AHLs) to mediate QS-regulated responses (Case et al., 2008). AHLs are extremely labile chemicals; they are rapidly degraded by abiotic and biological mechanisms (Yates et al., 2002; Hmelo \& Van Mooy, 2009). AHLs are constitutively produced at low levels by bacteria. However, in the absence of other bacteria, they do not accumulate in the extracellular environment due to diffusive loss and abiotic degradation to a biochemically inactive form. As bacteria proliferate in a given 
environment, the signal concentration builds up and a bacterium interprets this increase in concentration as an increase in a clonal population density. At a given threshold, the population simultaneously expresses genes under QS control. Often, the QS signal autoregulates its own production ('autoinduction') such that signal production increases dramatically once the extracellular signal concentration is reached (e.g. Fuqua et al., 1996).

The marine environment presents unique challenges to QS organisms. First, the aqueous environment allows for rapid diffusive loss of AHLs. Second, the $\mathrm{pH}$ of seawater is relatively basic $(\mathrm{pH}=8.2)$ catalyzing rapid base-hydrolysis of the lactone moiety of the AHL (lactonolysis, Yates et al., 2002). Finally, AHL-degrading enzyme activity is present in seawater (Hmelo \& Van Mooy, 2009). For these reasons, it should be expected that QS occurs only in specific niches within the ocean.

It has been predicted that a density of $10^{9}$ cells $\mathrm{L}^{-1}$ is the minimum threshold density required for QS bacteria to induce QS-regulated genes in the ocean (Hmelo \& Van Mooy, 2009). This density is not uncommon in biofilms; not only do biofilms host high densities of bacteria, but they also offer a physical barrier to prevent the diffusive loss of AHLs into seawater. Within biofilms, AHL concentrations are maintained at significantly higher concentrations (up to four orders of magnitude) than occur in the external environment (Charlton et al., 2000; Fekete et al., 2007). In addition to deterring the diffusive loss of AHLs, the chemical environment within biofilms is typically more acidic than the surrounding environment (Vroom et al., 1999) which will have a stabilizing effect on AHLs by reducing the rate of abiotic base-catalyzed lactonolysis. 
Biofilms are present on almost every living, detrital, and artificial surface in the ocean including algae, sinking particulate organic carbon, and man-made structures (Decho, 2000) and QS likely plays a role in the formation and function of these communities.

The detection of AHLs in marine samples is hindered by numerous challenges. AHLs are effective at low concentrations (0.1-400 nM, Kaplan \& Greenberg, 1985; Schaefer et al., 2002; Burton et al., 2005) and as already mentioned, they degrade rapidly in aqueous solutions. While high concentrations of AHLs may accumulate in biofilms (far greater than the minimum QS-induction thresholds of 0.1 to $400 \mathrm{nM}$ observed in culture, e.g. Charlton et al., 2002) they are likely much more dilute in seawater. Finally, the presence of AHLs can be masked by the presence of the other organic molecules in the natural environment (i.e. the matrix) that occur at or above the concentration of AHLs.

Recently, we constructed clone libraries derived from total Trichodesmium thiebautii community DNA in the Sargasso Sea (Hmelo, 2010). We detected a diverse population of bacteria consistent with previous reports suggesting that Trichodesmium spp. can host dense bacterial communities (up to $10^{8}$ cells $\mathrm{mL}^{-1}$ ) (Sheridan et al., 2002). Of the two clone libraries we produced (one derived from puff-morphology colonies and one derived from tuft-morphology colonies), 23 and 12 percent, respectively, were composed of Proteobacteria, many representatives of which are known to utilize QS in the laboratory.

We collected scanning electron micrographs and epifluorescence images of laboratory-cultivated Trichodesmium spp. (Figures 1 and 2). These figures reveal that 
high concentrations of bacteria organize in discrete clumps on the cell surface of Trichodesmium, suggestive of the types of structures produced by clonal populations (e.g. Davies et al., 1998; Riedel et al., 2001). On the basis of these images and the preceding arguments, we posit that the epibiont community associated with Trichodesmium spp. is

one in which QS is occurring. In order to test this hypothesis, we engaged in an effort to cultivate QS bacteria from Trichodesmium spp.

We isolated bacteria from natural populations of Trichodesmium collected at sea and surveyed each of them for AHL production using a broad-spectrum biosensor. We confirmed the presence of AHLs detected by the biosensor using sensitive mass spectrometric analysis (specifically, ion trap and Fourier-transform ion-cyclotron mass spectrometry). Our results highlight the advantage of combining microbiological and chemical approaches to the detection of AHLs in natural samples and provide a platform for additional studies of QS amongst Trichodesmium hosted bacterial populations. In addition, we suggest that the methods employed in this study are well suited to the analysis of AHLs in other complex marine-derived samples.

\section{METHODS}

\section{Isolation and cultivation}

\section{Isolation of cultivars from fresh Trichodesmium colonies}

Trichodesmium sp. colonies were collected in September 2008 on a cruise of the R/V Atlantic Explorer, at the Bermuda Atlantic Time Series (BATS) station. Colonies were collected from the near surface (approximately the upper 20m) by a hand-held $130 \mu \mathrm{m}$ 
plankton net and individual colonies were gently picked using an inoculating loop. Filters with discrete colonies were frozen at $-80^{\circ} \mathrm{C}$ for an additional isolation-effort at

WHOI. At sea, freshly-picked colonies were sequentially washed in three $0.2 \mu \mathrm{m}$-filtered seawater baths. Epibionts were isolated by streaking colonies of Trichodesmium onto agar plates made with either a base of Marine Broth (MB) or Vineyard Sound, MA seawater supplemented with $1 \mathrm{~g} \mathrm{~L}^{-1}$ tryptone (SWT). A control plate of each type of media was inoculated with a clean inoculating loop which was passed through the three $0.2 \mu \mathrm{m}$ filtered water baths. Single colonies of epibionts were picked and re-streaked to purity. Individual epibiont colonies were picked using a sterile inoculating loop and propagated in liquid media $(0.2 \mu \mathrm{m}$ filtered Vineyard Sound seawater amended with $1 \mathrm{~g}$ $\mathrm{L}^{-1}$ tryptone). $10 \%$ DMSO freezer stocks were prepared from overnight dense cultures and stored at $-80^{\circ} \mathrm{C}$.

\section{Isolation of cultivars from frozen Trichodesmium colonies}

Isolates were obtained in a separate cultivation effort at the Woods Hole Oceanographic Institution (WHOI). One filter that contained four frozen puff-type colonies was aseptically divided into quarters. Each section of filter was vortexed for 3 minutes in 1.5 $\mathrm{ml}$ of sterile Vineyard Sound seawater (VSS) to dislodge bacteria from the filter and then treated by three different methods which are described below.

(Method 1) Each piece of filter was stamped onto 3 plates, VSS prepared with 1\% agar, SWT prepared with $1 \%$ agar, and VSS amended with $1 \%$ methanol and 1 ug $\mathrm{ml}^{-1}$ vitamin 
B12 and prepared with $1 \%$ agar. Colonies were picked from these plates and streaked to purity on sterile solid media.

(Method 2) An aliquot of the VSS which was vortexed with the filter was streaked as a lawn onto one-third of each of the three types of plates described above. Each plate was then streaked to extinction. Colonies were picked from these plates and streaked to purity on clean plates.

(Method 3) Each of the wells in the first column of a 24 deep-well plate was inoculated with $100 \mu 1$ of the VSS used to vortex the filter. Each row contained $900 \mu 1$ of a different type of media: Row 1- VSS; Row 2- SWT; Row 3- Methylophaga Broth (Vitamin B12, 1 $\mathrm{mg} \mathrm{mL} \mathrm{m}^{-1}$, and Methanol, $0.5 \%$ in natural seawater diluted to $75 \%$ strength with MilliQ water) ; Row 4- mineral salts amended with $1 \% \mathrm{MeOH}$ and $1 \mu \mathrm{g} \mathrm{ml}^{-1}$ vitamin $\mathrm{B} 12$. Samples were serially diluted 10:1 across the rows, with the final (6th) well containing a $10^{-6}$ dilution of the original $1.5 \mathrm{ml}$ seawater-filter particle solution. These were incubated for 2 weeks and then spread onto plates to extinction similarly to Method 2 above. All incubations took place at $28^{\circ} \mathrm{C}$. Most isolates eventually were grown on SWT regardless of initial isolation-media in order to yield biomass sufficient for $16 \mathrm{~S}$ sequencing and cryopreservation. Few isolates grew in liquid media, cultures displaying growth at the liquid interface or in tight clumps were common.

(Method 4) Biofilms developed within the wells of the dilution plate inoculated as per Method 3, both along the walls of the wells and at the media-air interface. These biofilms were gently removed and streaked onto sterile solid media corresponding to the 
liquid media from which the biofilms were extracted. Colonies were picked from these plates and streaked to purity on sterile solid media.

\section{Biosensor assay}

Agrobacterium tumefaciens NTL4(pZLR4) is a broad-sensitivity biosensor detecting unsubstituted $\mathrm{C}_{6^{-}}, \mathrm{C}_{8^{-}}, \mathrm{C}_{10^{-}}, \mathrm{C}_{12^{-}}, \mathrm{C}_{14^{-}}$, all 3-oxo-AHLs, 3-hydroxy- $\mathrm{C}_{6^{-}}, \mathrm{C}_{8^{-}}$, and $\mathrm{C}_{10^{-}}$ AHLs (Farrand et al., 2002). The use of Agrobacterium as a biosensor strain for AHLs is described in detail in Farrand et al. (2002). Briefly, soft agar suspensions of the biosensor strain were prepared by adding $100 \mu \mathrm{L}$ of an overnight culture of $A$. tumefaciens NTL4(pZLR4) to a suspension of $0.5 \%$ agarose in water supplemented with $40 \mu \mathrm{g} / \mathrm{mL}$ X-Gal (5 Prime, Hamburg, Germany). Soft agar suspensions were overlaid on base plates of $1.5 \%$ agar in AB Minimal media (Chilton et al., 1974) supplemented with $0.2 \%$ glucose and $40 \mu \mathrm{g} / \mathrm{mL}$ X-Gal. $2.5 \mu \mathrm{L}$ of an overnight culture of A. tumefaciens NTL4, which does not produce any AHL, was spotted onto the overlays as a negative control. As a positive control, $2.5 \mu \mathrm{L}$ of an overnight culture of $A$. tumefaciens NT1(pTiC58), which constitutively produces AHLs, was spotted onto the overlays. Control plates in which A. tumefaciens NTL4(pZLR4) was not seeded into the soft-agar overlay were prepared and treated in parallel. Overnight cultures of strains to be tested for AHL production were spotted onto the soft agar overlay in $2.5 \mu \mathrm{L}$ aliquots. At 24 hours, plates were checked for growth and the appearance of a blue spot. The appearance of a blue zone at the site of sample application constitutes a positive response suggesting the presence of AHLs. 


\section{Organic Extraction of AHLs}

Cultured Trichodesmium isolates which elicited a positive response by the biosensor assay were grown in $200 \mathrm{~mL}$ SWT broth. After 24 hours, cells were removed by filtration; the spent media was acidified to $\mathrm{pH} 2$ with concentrated hydrochloric acid.

Ethyl acetate and dichloromethane are commonly used as extraction solvents for AHLs (reviewed in Fekete et al., 2007). However, ethyl acetate has been shown to be a more effective solvent (Eberhard et al., 1981) and is improved further by slight acidification by $0.1 \%$ formic acid (Ravn et al., 2001). Spent media was extracted three times each with $60 \mathrm{~mL}$ acidified $(0.1 \%$ formic acid) ethyl acetate. The combined extracts were passed through a column of combusted sodium sulfate to remove residual water and concentrated by rotory evaporation for analysis by high performance liquid chromatography (HPLC)- mass spectrometry (MS). Analytical controls were performed by extracting clean MilliQ water into ethyl acetate and performing all downstream sampling handling and preparation. All control extracts were free of AHLs.

\section{HPLC-ESI-MS}

Extracts were transferred in ethyl acetate to glass vials for analysis on either a Surveyor HPLC coupled to a LCQ Deca-XP ion trap MS or a Surveyor HPLC coupled to a LTQUltra ion trap/ 7-T Fourier transform-ion cyclotron resonance MS (FT-ICR-MS, all instruments are Thermo Finnigan/ Thermo). In either case, samples were ionized via an electrospray ionization (ESI) interface. Separation of AHLs was achieved by running a water-acetonitrile gradient through an Altima HP C18 reverse-phase chromatography 
column (Agilent; $5 \mu \mathrm{m}, 2.1 \times 150 \mathrm{~mm}$ ) with guard column. Eluent A was MilliQ water with $0.1 \%$ formic acid and eluent $\mathrm{B}$ was acetonitrile with $0.1 \%$ formic acid. The gradient program was as follows: $0-25 \mathrm{~min}$, gradient from $90 \% \mathrm{~A} / 10 \% \mathrm{~B}$ to $100 \% \mathrm{~B} ; 25-26 \mathrm{~min}$, $100 \% \mathrm{~B} ; 26-27 \mathrm{~min}$, gradient to $90 \% \mathrm{~A} / 10 \% \mathrm{~B} ; 27-36 \mathrm{~min} 90 \% \mathrm{~A} / 10 \% \mathrm{~B}$ (column equilibration).

Electrospray conditions in the LCQ-MS are as follows: The source voltage was set to $4.5 \mathrm{kV}$, the capillary temperature was set to $275^{\circ} \mathrm{C}$, and the capillary voltage was set to $1.5 \mathrm{~V}$. In the LTQ, the source voltage was set to $4.2 \mathrm{kV}$, the capillary temperature was set to $265^{\circ} \mathrm{C}$, and the capillary voltage was set to $27.5 \mathrm{~V}$. Full Scan experiments were performed in the LCQ-MS and the FT-ICR-MS in the range $\mathrm{m} / \mathrm{z} 160-500$. Masses were acquired by the LCQ at low resolution (nominal mass resolution) and at 100,000 (FWHM) at m/z 400 by the FT-ICR-MS. In the LCQ ion trap, secondary mass spectra were collected for parent ions from a comprehensive list of 3-oxo, 3-hydroxy, and fully reduced AHLs ranging from $\mathrm{C} 4$ to $\mathrm{C} 16$. In contrast, secondary mass spectra were only collected for ions with a nominal $\mathrm{m} / \mathrm{z}$ of $242,256,270$, and 284 in the LTQ ion trap. These masses correspond to the nominal masses of AHL-like compounds detected by LCQ-MS. If none of the four parent ions were present, secondary mass spectra were collected for the most intense ion.

\section{DNA extraction}

DNA was obtained from $1 \mathrm{~mL}$ aliquots of overnight cultures of cultivars grown in SWT media. Cells were pelleted by centrifugation and extracted by phenol-extraction 
according to a protocol adapted from J. Marmur (1961). Aliquots of DNA (25-100 ng) were added as template to polymerase chain reactions (PCR) for amplification of the SSU rRNA gene sequence. Each PCR consisted of the following: $0.2 \mathrm{mM}$ dNTPs each, $0.5 \mathrm{uM}$ each forward primer 27F (5', AGAGTTTGATCMTGGCTCAG) and reverse primer 1492R (5' TACGGYTACCTTGTTACGACTT) (Invitrogen, Carlsbad, CA), 2 units Paq5000 thermostable proofreading polymerase (Stratagene, La Jolla, CA), for a $20 \mu \mathrm{L}$ final reaction volume. PCR cycles were as follows: an initial denaturation step of 2 minutes at $94^{\circ} \mathrm{C} ; 30$ seconds at $94^{\circ} \mathrm{C}, 30$ seconds at $55^{\circ} \mathrm{C}$, and 90 seconds at $72^{\circ} \mathrm{C}$ for a total of 30 amplification cycles.

\section{Sequencing, Taxonomic assignments and Phylogenetic analysis}

End-sequencing of PCR amplicons was performed offsite either by MWG-Operon (Huntsville, AL) or Agencourt Biosciences (Beverly, MA). Raw sequences were aligned via the web-based SINA aligner (http://www.arb-silva.de/aligner/). Aligned sequences were imported into ARB (Ludwig, 2004) (version 07.12.07). The Ribosomal Database Project II Classifier (Cole et al., 2003) was used to assign provisional taxonomic affiliations all sequences. BLASTn searches (Altschul et al., 1997) of the National Center for Biotechnology Information (NCBI) 16S rRNA gene sequence databases were performed to confirm taxonomic placements. 


\section{Scanning electron microscopy (SEM)}

SEM was performed with a JEOL JSM-840 1- 35KV (JEOL, Tokyo, Japan) scanning electron microscope at the Marine Biological Laboratory Central Microscopy Facility (MBL-CMF). Samples were prepared according to standard operating protocol supplied by MBL-CMF. Briefly, colonies of Trichodesmium erythraeum strain K-11\#131 were fixed with 4\% gluteraldehyde in phosphate-buffered saline (PBS), dehydrated in a concentration series of ethanol in PBS (10\% to $100 \%$, in $10 \%$ steps), critical point dried using a Tousimis Samdri 780A Critical Point Dryer and sputtered with gold in Tousimis Samsputter-2a (Tousimis, Rockville, MD).

\section{Epifluorescence microcroscopy}

Individual colonies of T. erythraeum strain K-11\#131 were picked using an inoculating loop and gently placed on a clear glass microscope slide and mixed with a stain cocktail

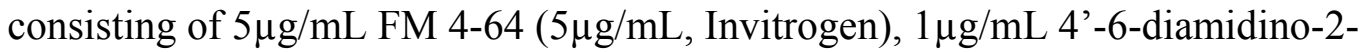
phenylindole (DAPI, vendor) and 30 $\mathrm{g} / \mathrm{mL}$ MitoTracker Green FM (Invitrogen) and immobilized with a poly-L-lysine coated coverslip (Fisher scientific). Cells were visualized using rhodamine, DAPI and acridine orange filter sets.

\section{RESULTS}

\section{Microscopy}

Microscope images revealed bacteria growing in dense colonies on Trichodesmium

(Figure 1). It should be noted that bacteria are observed in lightly populated patches 
(Figure 1, a) as well as in dense, clump-like colonies which protrude from the surface (Figure 1, b). Bacteria appear to associate directly with the Trichodesmium surface (Figure 1, a) as well as with the mucilaginous sheath surrounding the colonies (Figure 1, $\mathrm{b}$ and $\mathrm{c}$, Figure 2). The occurrence of dense populations of bacteria in "ghost sheaths" visible in Figure 2 is particularly striking and highlights the elevated concentration of epibiotic bacteria in the sheath.

\section{Phylogenetic analysis}

78 cultivars (excluding the 8 isolated from the control seawater) were isolated from fresh Trichodesmium colonies collected at the BATS site (listed in Supplemental Table 1). An additional 63 cultivars were isolated from frozen colonies (listed in Supplemental Table 2). Of the four methods used to isolate epibionts from frozen Trichodesmium colonies, methods 1, 3, and 4 were successful. No cultivars were obtained using Method 2. The greatest number of frozen-colony derived cultivars was obtained using Method 1 (46 of 63). Regardless of the method of isolation, almost all of the cultivars were isolated on either VSS (10 total) or SWT (52 total) media. In fact only one cultivar was obtained by using another media type; One cultivar (A137) was isolated using Methylophaga medium by means of Method 4 . With respect to Methods 3 and 4, with one exception, only the 1:10 and 1:100 dilutions yielded isolates. A137 was isolated by streaking a 1:1000 dilution onto Methylophaga media.

The epibionts which were isolated from fresh Trichodesmium colonies and frozen Trichodesmium colonies differed with respect to one another. Of the 78 cultivars isolated 
from fresh samples, $83 \%$ were related to Proteobacteria and $12 \%$ were related to Actinobacteria. In contrast, $79 \%$ of the 63 cultivars isolated from the frozen filter were related to Actinobacteria and only $6 \%$ were related to Proteobacteria. $8 \%$ of cultivars isolated from the frozen filter were related to the Bacteroidetes while no Bacteroidetes were isolated from fresh Trichodesmium colonies. All five of the Bacteroidetes isolated from the frozen Trichodesmium colonies were cultivated by Method 3 or 4 on SWT media. For the remainder of the results and discussion, the cultivars obtained from either fresh or frozen colonies will be considered as one population.

These isolates can be assigned to 5 phylogenetic classes; $43 \%$ of cultivars (61 individuals) are related to the Actinobacteria, 27\% (39 individuals) are related to the Alphaproteobacteria, 24\% (34 individuals) are related to the Gammaproteobacteria, 4\% (5 individuals) are related to the Flavobacteria, and 2\% (3 individuals) are related to the Firmicutes (Figure 2). Of the 79 cultivars isolated on MB or SWT media at sea, all share 97 percent sequence identity (PSI) or greater with their nearest neighbors in GenBank (Table 3). Of the 63 isolates which were cultivated from frozen colonies in the laboratory, all but 12 share 97 PSI or better with their nearest GenBank neighbor. Ten of these 'novel' isolates cluster within the Actinobacteria and differ from their nearest GenBank neighbor by up to 11 PSI. The other two 'novel' isolates are members of the Flavobacteria and Alphaproteobacteria and differ from their nearest GenBank neighbor by 7 and 6 PSI, respectively.

The Alphaproteobacteria are composed of members of two orders, the Sphingomonadales (54\%) and the Rhodobacterales (46\%). Of the isolates within each of 
these orders, $96 \%$ can be assigned to either Erythrobacter or Paracoccus, respectively. The gammaproteobacterial class is more diverse and is composed of $15 \%$ Pseudomonadales, $10 \%$ Chromatiales, 35\% Vibrionales, and 38\% Alteromonadales. The 5 Flavobacteria isolates are all within the genus Vitellibacter of the Flavobacteriales. All of the Actinobacteria are members of the Actinomycetales and $85 \%$ can be assigned to a known genus.

The marine broth negative control plate did display growth of contaminant colonies, albeit very few. In total, 8 cultivars were isolated; four were members of the Firmicutes (genera Bacillus), three were members of the Sphingomonadaceae, and one was a member of the Micrococcaceae.

Detailed phylogenetic placements of all cultivars isolated in this study were determined using the neighbor joining algorithm in ARB and are displayed in Figure 3. The nearest neighbors in GenBank are listed in Supplemental Tables 1 and 2.

\section{Limit of Detection}

The initial survey instrument used in this experiment was the LCQ-MS (ion trap MS). Based on linear calibration from 2 pmol to 1000 pmol injection of standard AHLs, the limit of detection, defined as the concentration at which an integratable peak has a height three times the baseline, is 10 pmol. If we achieve $100 \%$ extraction efficiency, we should be able to detect AHLs present at concentrations of $50 \mathrm{pM}$ or higher in the $200 \mathrm{~mL}$ cultures grown for this experiment. This corresponds to three orders of magnitude less than the physiologically relevant concentrations of $10 \mathrm{nM}$ and higher which are the 
lowest documented concentrations which will induce a QS response (Kaplan \& Greenberg, 1985).

\section{Biosensor hits and AHL analysis}

14 isolates produced a positive response on the A. tumefaciens biosensor (Table 1). We tested 12 of these isolates by mass spectrometry. AHLs were detected by LCQ-MS in 7 isolates and using FT-ICR-MS we were able to identify one additional AHL-producing strain (for a total of eight, see Table 1); the specific AHLs detected in each strain are summarized in Table 2. Using LCQ-MS, AHLs were detected in four Vibrio strains (A507, A468, A491, and A477) and three Erythrobacter sp. strains (A537, A541, and

A513). Five of the strains which induced a positive reaction from the biosensor did not produce AHLs detectable by the LCQ-MS methods employed here. The biosensorpositive, AHL-negative (by LCQ) isolates are A463, A484, A492, A072, and A111. These correspond to a Vibrio sp., Alteromonas sp., Erythorobacter sp., Gordonia sp., and Rhodococcus sp., respectively. Detailed phylogenetic information can be found in Figure 3 and Supplemental Tables 1 and 2.

LCQ analysis revealed that the AHL-producing Vibrio spp. produced appreciable quantities (detected as an 'integratable' peak with approximately three times the height of the baseline) of compounds that we tentatively identified as $3-$ oxo- $\mathrm{C}_{9}, 3-\mathrm{oxo}_{-} \mathrm{C}_{10}$, and 3 oxo- $\mathrm{C}_{11}$-HSLs. Standards of 3-oxo- $\mathrm{C}_{9}, 3$-oxo- $\mathrm{C}_{10}$, and 3-oxo- $\mathrm{C}_{11}$-HSLwere not available at the time of analysis and so the abovementioned compounds were tentatively identified on the basis of their estimated retention time, fragmentation pattern and exact mass as 
determined by FT-ICR-MS. The FT-ICR-MS generates masses accurate to $1 \mathrm{ppm}$ which is sufficient to assign an elemental formula; in combination with chromatographic retention data and secondary mass spectra, it is possible to tentatively assign a molecular structure.

We have previously observed that the efficiency with which AHLs are ionized by the electrospray ionization source varies according to the chain length of the acyl chain (also documented by Ortori et al., 2007), thus the relative response factor (RRF) of the analytical method is different for each individual molecule. As such, we were unable to quantify these compounds on the basis of a calibration curve generated using similar AHL for which a standard was available. Appreciable quantities of 3-oxo- $\mathrm{C}_{8}$-HSL were detected in Vibrio sp. A468 and A491 and trace quantities (defined as a peak which is less than three times the height of the baseline) were present in A477. No 3-oxo- $\mathrm{C}_{8}-\mathrm{HSL}$ was detected in cultures of strain A507. To avoid contaminating culture media with trace exogenous AHLs, we did not spike the samples with an internal AHL standard prior to extraction. Thus, we were unable to quantify the AHLs produced by AHL-producing cultivars.

The FT-ICR MS is a more sensitive analytical detector than the LCQ-MS and we were able to indentify two additional AHLs in the Vibrio spp. by FT-ICR MS that we did not detect by LCQ. Significant peaks of 3-oxo- $\mathrm{C}_{12}$-HSL were detected in all four Vibrio spp. and $\mathrm{C}_{12}$-HSL was detected in A507, A491, and A497. $\mathrm{C}_{12}$-HSL was present in extremely low quantity and a peak was not present. However, the high resolving power 
of the FT-ICR-MS allows the identification of the $\mathrm{C}_{12}$-HSL molecular ion at the chromatographic retention time at which the $\mathrm{C}_{12}$-HSL standard elutes (Figure 3).

The AHL profiles of the Erythrobacter spp. A537, A541, and A513 are quite

different. Spent media from Erythrobacter isolates A537 contained trace quantities of 3oxo- $\mathrm{C}_{8}-\mathrm{HSL}$ as determined by LCQ analysis, compared to a standard. LCQ analysis determined that A541 and A513 produced appreciable quantities of $\mathrm{C}_{12}$-HSL. When we analyzed these same samples by FT-ICR-MS, we detected appreciable quantities of $\mathrm{C}_{13^{-}}$ and $\mathrm{C}_{14}$-HSL in A541 and A513 as well.

Although no AHLs were detected in the Vibrio strain A463 (99 PSI Vibrio sp. S1162) by LCQ-MS. FT-ICR-MS revealed a suite of AHLs from 3-oxo-C 8- $^{-}$to 3-oxo$\mathrm{C}_{11}$-HSL in the extract. A463 thus produced AHLs, albeit at a lower concentration than the other Vibrio strains investigated, assuming extraction efficiencies are identical culture to culture.

\section{DISCUSSION}

In order to address the hypothesis that epibiotic bacteria associated with Trichodesmium spp. engage in QS, we isolated 142 cultivars from samples collected at BATS. To make efficient use of analytical resources, it was useful to assay these samples for the presence of AHLs with a rapid and high-throughput method before performing the more laborious chemical analyses necessary to identify specific structural variants of AHL. We used a broadly sensitive biosensor A. tumefaciens NTL4(pZLR4) in this initial survey. 
In this study, we found that only eight of twelve isolates which induced a positive response by the Agrobacterium biosensor actually produced AHLs. Culture media from the "biosensor-positive" isolates was analyzed by MS and in only eight cases, contained AHLs which could be positively identified by comparison to authentic standards or tentatively identified by their relative chromatographic retention time, fragmentation patterns, and exact mass. Four of the "biosensor-positive" isolates did not produce AHLs which could be detected by the methods employed in this study; in fact, biosensors have been previously criticized for producing false positive hits (Holden, 1999; Ortori et al., 2007; Garcia-Aljaro et al., 2008). While the lack of MS-detectable AHLs in four of the culture media-extracts may signal that the biosensor provided a 'false positive', a few other explanations deserve consideration. First, the detection limit of the biosensor used in this study (0.02 pmol, Ravn et al., 2001), is lower than that of the LCQ-MS (10 pmol). Second, the production of AHLs by a given bacterium generally occurs within a relatively short and highly specific portion of the growth phase (e.g. Blosser-Middleton \& Gray, 2001); as a result, small differences in the length of incubation leading up to the biosensor assay or chemical analysis may translate into large differences in AHL concentrations. Despite these potential explanations for the discrepancy between the biosensor analysis and chemical analysis, the biosensor result cannot stand alone; chemical analysis is necessary in order to absolutely confirm the presence of AHLs in a sample.

For several reasons, the methods employed in this study provide only a lower limit on the proportion of the epibiont community which may be capable of producing 
AHLs. First, as mentioned above, the concentration of AHL is strongly dependent on the growth stage of the cell cultures (Blosser-Middleton \& Gray, 2001; Brelles-Marino \& Bedmar, 2001 and references therein) but we did not measure AHLs at all stages of the batch culture growth cycle (lag, early and late exponential, and stationary phases). It is reasonable to hypothesize that many more of the isolates related to known AHLproducing genera produce AHL, and if we had sampled them earlier or allowed the cultures to grow longer we might have detected these.

Second, the cultivable bacteria only represent a very small minority of the bacteria associated with Trichodesmium colonies. Clone library analysis of wild Trichodesmium collected at the same site reveal the presence of a plethora of proteobacterial genera (Hmelo, 2010), some portion of which likely utilize QS as a metabolic strategy. It is well known that clone libraries are very efficient at capturing the abundant taxa in an ecosystem and cultivation efforts are often biased towards detecting low-abundance populations (Pedrós-Alió, 2006). Indeed, we isolated bacterial taxa (e.g. Vibrio and Erythrobacter) which are typically cultured from marine habitats but are not major components of clone libraries (Giovannoni \& Rappe, 2000).

Third, it has been previously demonstrated that many AHL-producing bacteria do not produce AHLs in high-nutrient media and thus may have produced AHLs had we selected different growth conditions (Brelles-Marino \& Bedmar, 2001). Some bacteria only produce AHLs given a particular carbon substrate. For example, the methylotroph Methylobacterium extorquens AM1 only produces AHLs when grown under methylotrophic conditions (Nieto Penalver et al., 2006). We detected bacteria with 
similarity to methylotrophic clades (e.g. members of the Thiotrichales), however, we have not yet tested their ability to produce AHLs under methylotrophic conditions.

Finally, our MS-analyses were directed by our biosensor responses. Biosensors only detect a limited suite of AHL structures and are variably sensitive to those which it can detect (Brelles-Marino \& Bedmar, 2001). We chose A. tumefaciens NTL4 (pZLR4) because it detects a broad range of AHLs and favors the long-chain varieties which tend to dominate in marine bacteria (Wagner-Dobler et al., 2005; Decho et al., 2009). It will not, however, detect short-chain AHLs or homoserine-lactone derivatives with unusual structures, such as the p-coumaroyl homoserine lactone (Schaefer et al., 2008) or branched AHLs (Thiel et al., 2009). Similarly, we used LCQ-MS to select samples to be analyzed by FT-ICR-MS. Thus it is possible that isolates which produce low-abundance AHLs would have been overlooked by LCQ-MS. Indeed, isolate A463 produced AHLs which were detectable by FT-ICR-MS but not by LCQ-MS. Ion-trap MS is a very common tool in the analysis of AHLs from biological samples (Morin et al., 2003; Nieto Penalver et al., 2006); however, our results suggest that this type of instrument may not be the most appropriate tool for the comprehensive analysis of AHLs from extremely complex matrices.

The analysis of AHLs in environmental samples requires a selective and sensitive technique which is capable of detecting AHLs within a complex sample matrix. While the LCQ-MS enables convenient and relatively inexpensive investigation of molecular structures, it can only measure mass-to-charge at nominal mass unit resolution which can be problematic if an analyte of interest is 'buried' in a complex chemical matrix. On the 
other hand, the FT-ICR-MS is highly sensitive and selective in addition to measuring mass-to-charge with remarkable accuracy $(+/-1 \mathrm{ppm})$. We were able to use the FT-ICRMS to distinguish $\mathrm{C}_{12}$-HSL from a background which masked its presence using the nominal mass resolution device (LCQ-MS, Figure 3). FT-ICR-MS has been successfully utilized to identify known and unknown AHLs in complex culture extracts previously (Cataldi et al., 2008) and here we confirmed that, with respect to isolates grown in a seawater-medium, this technique is more sensitive and capable of identifying a wider range of AHLs with respect to the LCQ-MS.

All of the AHLs which were detected in this study were produced by bacteria related to known AHL-producing lineages, namely Vibrio spp. (Milton, 2006) and members of the Roseobacter clade (Martens et al., 2007), both members of the Proteobacteria. To our knowledge, this is the first report of bacteria closely related to the Erythrobacter genus having been demonstrated to produce AHLs.

Proteobacteria, which contains both Vibrio spp. and members of the Roseobacter clade, is the only phylum which contains bacteria known to harbor homologues of the AHL-synthesizing protein, LuxI. Scattered reports of QS by cyanobacteria (Sharif et al., 2008), archaea (Paggi et al., 2003), and a member of the Cytophoga-flavobacteriumbacteroidetes clade (Romero, 2010)) appear in the literature. While Sharif et al. (2008) assert that their cyanobacterial culture (Gleothece PCC6909) was axenic, AHL production did not begin to increase rapidly until 55 days. QS bacteria with luxI homologues whose QS systems have been characterized in the laboratory tend to produce their AHL signals on the order of hours rather than days (e.g. Blosser-Middleton \& Gray, 
2001). In the absence of the discovery of a luxI homologue in Gleothece, it is tempting to conclude that these results reflect contamination of the culture by a QS-heterotrophic bacterium after a lengthy incubation period. Biosensor data alone was provided to support the claim of QS in the archaeon Natronococcus occultus (Paggi et al., 2003), and as discussed earlier, biosensor data is subject to false positive reports. While the results of Romero (2010) do provide compelling evidence of AHL production by a CFB bacterium, all three of these reports will require independent replication and genetic evidence to convincingly and conclusively prove that QS is not constrained to the Proteobacteria. Interestingly, a complete luxI/R circuit is present in the genome of a Leptospirillum sp. (phylum, Nitrospirae), however, this bacterium is not in culture and thus its QS system can not be further investigated (Simmons et al., 2008).

The prospect of extending the range of QS is exciting as it would expand the range of potential inter-species and inter-phylum interactions in mixed bacterial communities and provide insight into the evolutionary origins of the QS. In this study, three actinobacterial strains isolated in this study induced a positive response by the biosensor used in this study (A072, A111 and A113). We evaluated culture extracts from two of these strains (A072 and A111) using LCQ-MS but we did not detect any AHLs. Strains A111 and A113 share 99 PSI with a Rhodococcus sp. (accession number FJ497702) while strain A072 shares only 92 PSI with its nearest neighbor in GenBank (Gordonia sp. FWA92). On the basis of 16S rRNA sequence data, isolate A072 is a novel bacterium which has not yet been characterized. Perhaps future characterization of this bacterium will reveal the ability to produce AHLs; in the absence data other than its 
ribomosaml RNA gene sequence, we can not preclude this possibility. Regardless, it may be interesting to pursue a more aggressive characterization of the spent culture media from this isolate in order to identify the chemical responsible for inducing the biosensor.

The AHLs detected in this study (3-oxo- $\mathrm{C}_{8}$ to 3 -oxo- $\mathrm{C}_{12}-\mathrm{HSL}$ and $\mathrm{C}_{12}$ - to $\mathrm{C}_{14-}$ HSLs) are typical of the AHLs which are often observed in marine environments and in isolates of marine bacteria. Long chain AHLs are often prevalent in marine-derived samples, likely because their long chain length renders them more stable than their shortchain homologues (Hmelo \& Van Mooy, 2009). The suites of AHLs detected in this study, namely the 3-oxo- $\mathrm{C}_{8}$ to 3 -oxo- $\mathrm{C}_{12}$-HSL series in the Vibrio spp. and the $\mathrm{C}_{12}$ - to $\mathrm{C}_{14}$-HSL suite in the Erythrobacter spp. raise an interesting question about the ecological role of AHLs. Are the individual AHLs deliberately synthesized by the cells, i.e. each by a unique LuxI protein, or are they the bi-products of a single LuxI which is able to interact with a range of acyl-precursors? The latter phenomenon has been documented (Marketon et al., 2002) although the biological (and ecological) relevance has yet to be established (Waters \& Bassler, 2005). Promiscuous production of AHLs could interfere in the signaling of neighboring bacterial colonies although co-evolved populations in biofilms may account for such production. Similarly, this promiscuous production could render the 'accidental' AHLs biologically irrelevant in a system which has evolved in their presence. Investigations of AHL-QS in multi-species communities are in their infancy. Existing studies only often consider two bacteria grown in co-culture (Riedel et 
al., 2001; Dulla \& Lindow, 2009). Investigations of QS in biofilms with two or more members will be necessary in order to answer these types of questions in the future.

\section{Future directions and recommendations}

A crucial piece of data necessary to definitively implicate QS in epibiont interactions will be the detection of an AHL from Trichodesmium cultures. This is a formidable task: Although concentrations of AHLs may reach $\mathrm{mmol} \mathrm{L}^{-1}$ concentrations within a given microcolony, this may not translate into a large number of molecules on the scale of a batch culture of Trichodesmium colonies. Indeed, we have invested considerable effort into extracting AHLs from laboratory-derived cultures of Trichodesmium spp. without detecting so much as trace amounts of the molecules. It should be noted that all of our initial MS work was performed by LCQ-MS. If we are to detect AHLs in batch cultures or environmental samples of Trichodesmium, the results of this study suggest that FTICR-MS, as well as triple-quadrupole-MS, another highly sensitive and selective form of mass spectrometry, are more appropriate analytical tools.

Potential improvements and enhancements to the cultivation of QS-bacterium from epibiont communities include the use of creative media designed to target specific organisms which are present in the clone library. These modifications could include amending some of these media with AHLs. We are targeting bacteria which are capable of complex interactions with their communities, and efforts to obtain them in pure culture may be improved by adding exogenous AHLs to the media. This technique has been successfully employed in improving the efficiency of cultivating bacteria from Baltic Sea 
seawater (although the addition of cAMP was even more successful) (Bruns et al., 2002). One reason why the addition of AHLs improves cultivation efficiency may be that AHLQS is involved in a population's resuscitation from lag phase (Bruns et al., 2002 and references therein). Other studies have demonstrated that many difficult-to-cultivate bacteria may need not only signal molecules, but other growth factors from neighboring bacterial populations, such as siderophores (D'Onofrio et al., 2010).

Finally, we can use cultivation-independent approaches to investigate the occurrence of QS using laboratory cultured Trichodesmium spp. For example, the effects of AHLs on laboratory-cultured Trichodesmium spp. can be gauged by amending cultures with AHLs produced by epibionts and monitoring specific features of the batch culture. (A preliminary experiment of this variety is included in this dissertation in Appendix 2) Alternatively, it may be possible to perform gene expression or protein expression experiments in which the effects of endogenous AHLs on the Trichodesmium community can be assessed.

\section{Conclusions}

In this study, we attempted to isolate QS-bacteria from Trichodesmium in order to begin investigating the role of QS in the cell-cell interactions of epibiotic populations. We showed that Trichodesmium-associated Vibrio isolates produce AHLs. We also demonstrated for the first time that (Trichodesmium-associated) Erythrobacter spp. produce AHLs. While we were successful in demonstrating that individual strains of Trichodesmium-associated epibionts possess the ability to utilize QS, a few crucial data 
points remain to be acquired to definitively make the case that QS occurs in the mixedepibiont community. The epibiotic bacteria associated with Trichodesmium are important for the ecology of Trichodesmium and the biogeochemistry of the ocean. Obtaining isolates of these bacteria in culture, will allow us to begin to assess their metabolic strategies and contributions to marine biogeochemical cycling. 

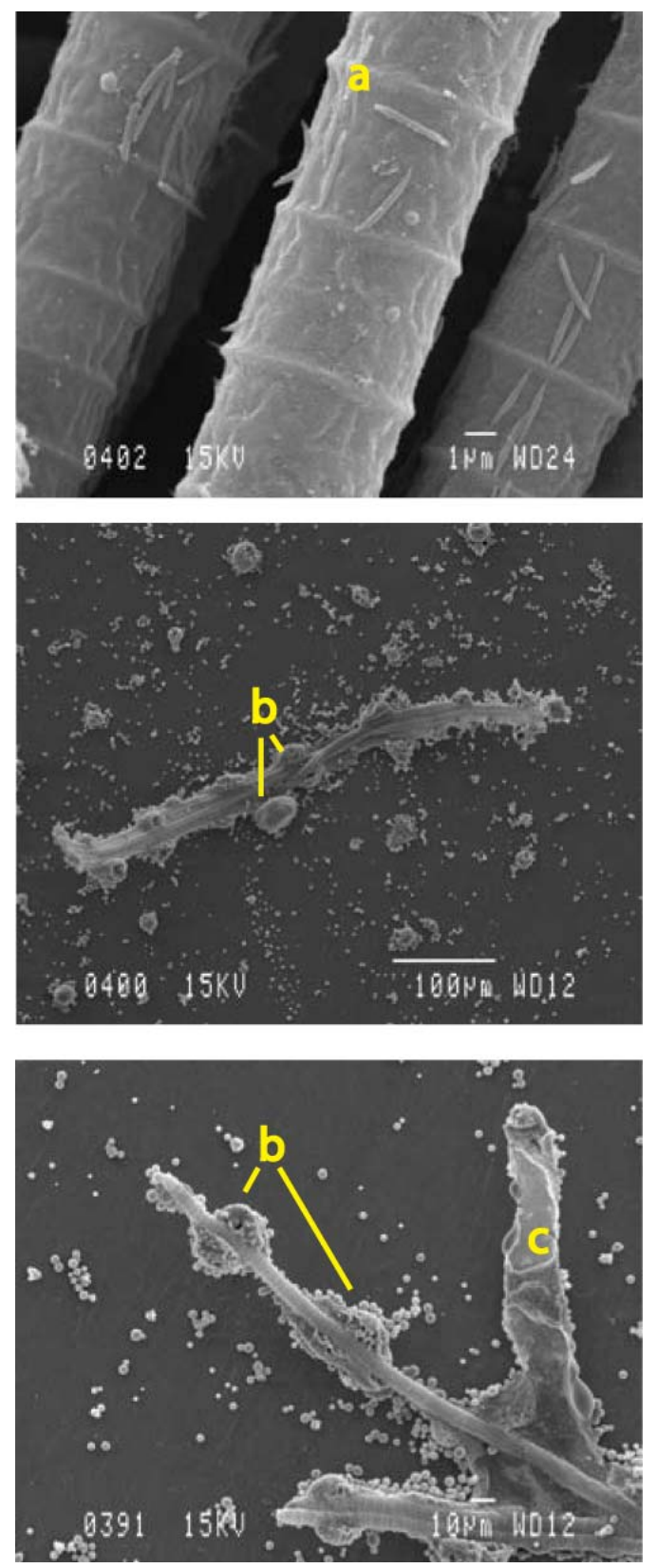

Figure 1. SEM images of T. erythraeum strain K-11\#131. Different areas of the filaments are characterized by light or heavy colonization of bacteria ( $a$ or $b$, respectively). High densities of bacteria tend to cluster in discrete 'clumps' or 'nodes' which extend from the cell surface of Trichodesmium. (b). Note the presence of a vacant mucilaginous sheath (c) and the heavy colonization of bacteria within it. 


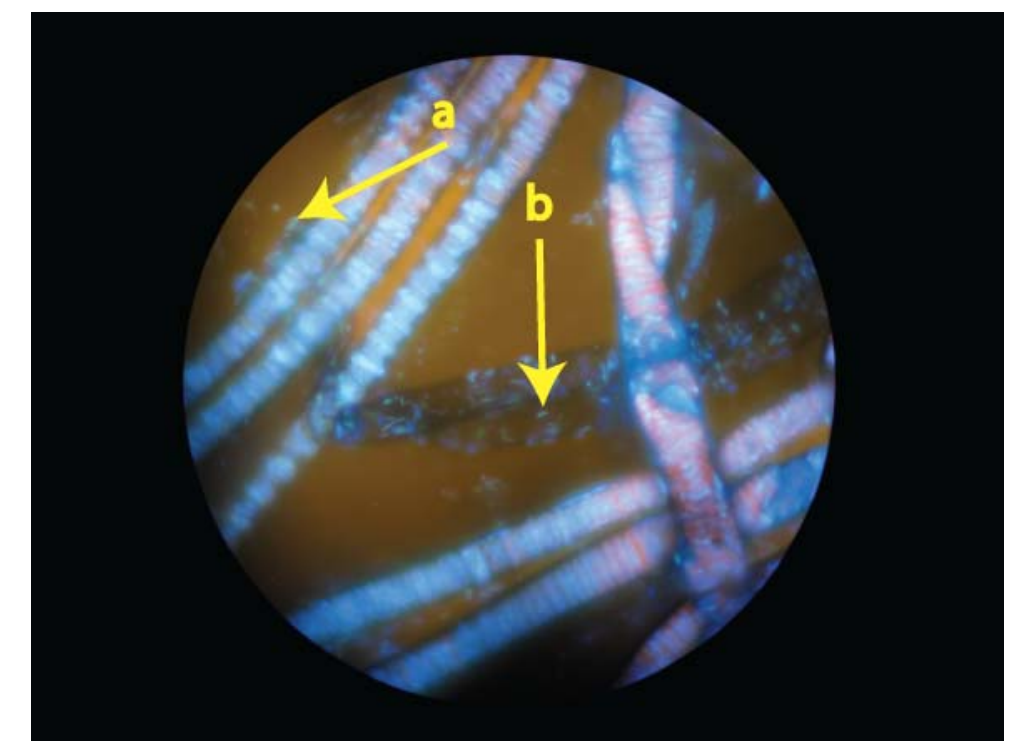

Figure 2. Epifluorescense image of K-11\#131 stained with DAPI. Methods are described in the text. Note the dense concentrations of bacteria (discrete clusters) associated with the surface of Trichodesmium filaments (a). Of special note in this image is the presence high numbers of bacteria in an empty ("ghost") mucilaginous sheath (b). 


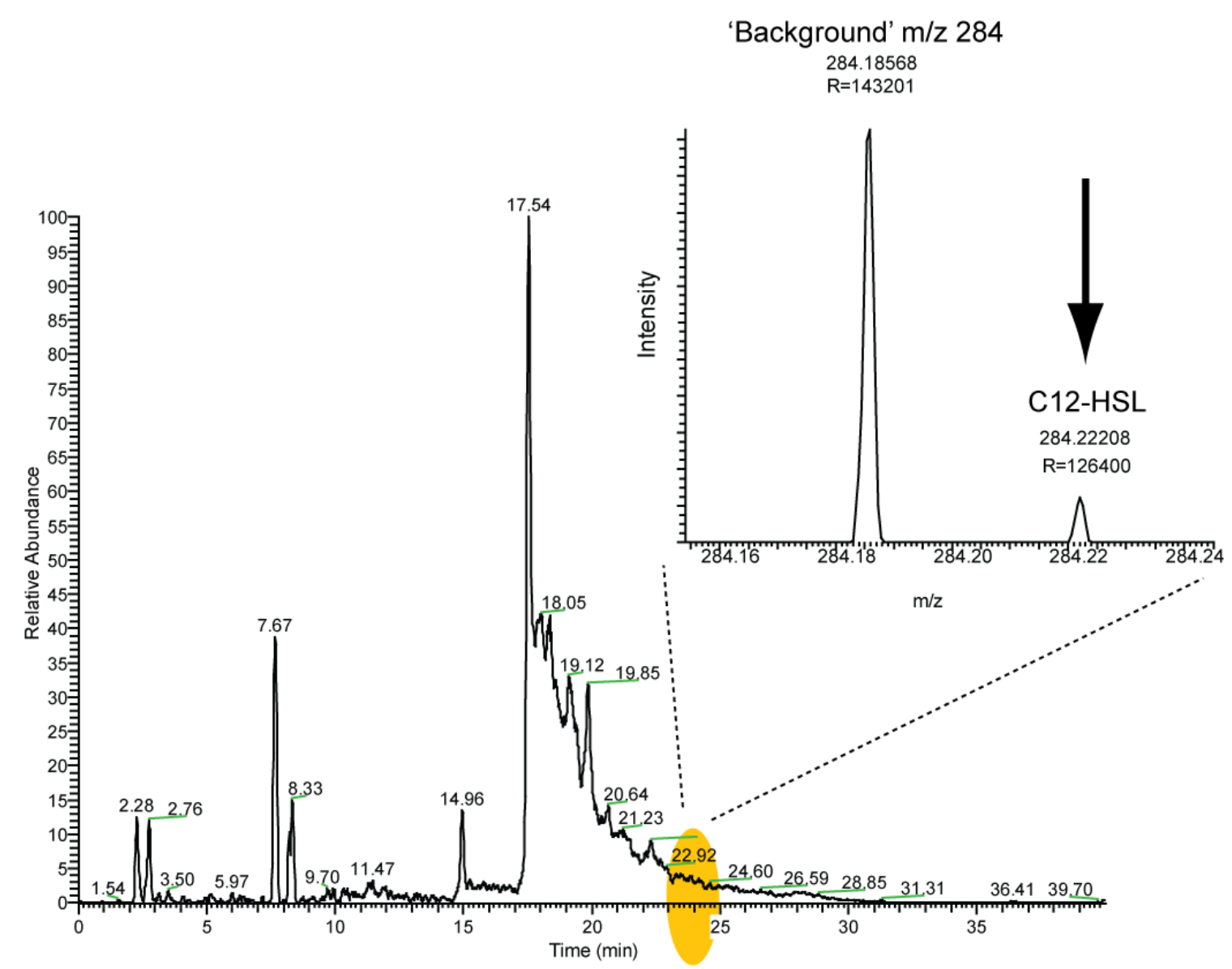

Figure 3. Extracted ion chromatogram showing the intensity of ions with a nominal mass-to-charge ratio $(\mathrm{m} / \mathrm{z})$ of 284 . The inset illustrates the power of high mass resolution to separate the molecular ion of C12-HSL (m/z 284.22208) from the 'background' $\mathrm{m} / \mathrm{z}$ 284.18568 at the chromatographic retention time of an authentic C12-HSL standard (22.9 minutes, indicated by yellow shading). ' $R$ ' indicates the resolution of the mass spectral peak. 


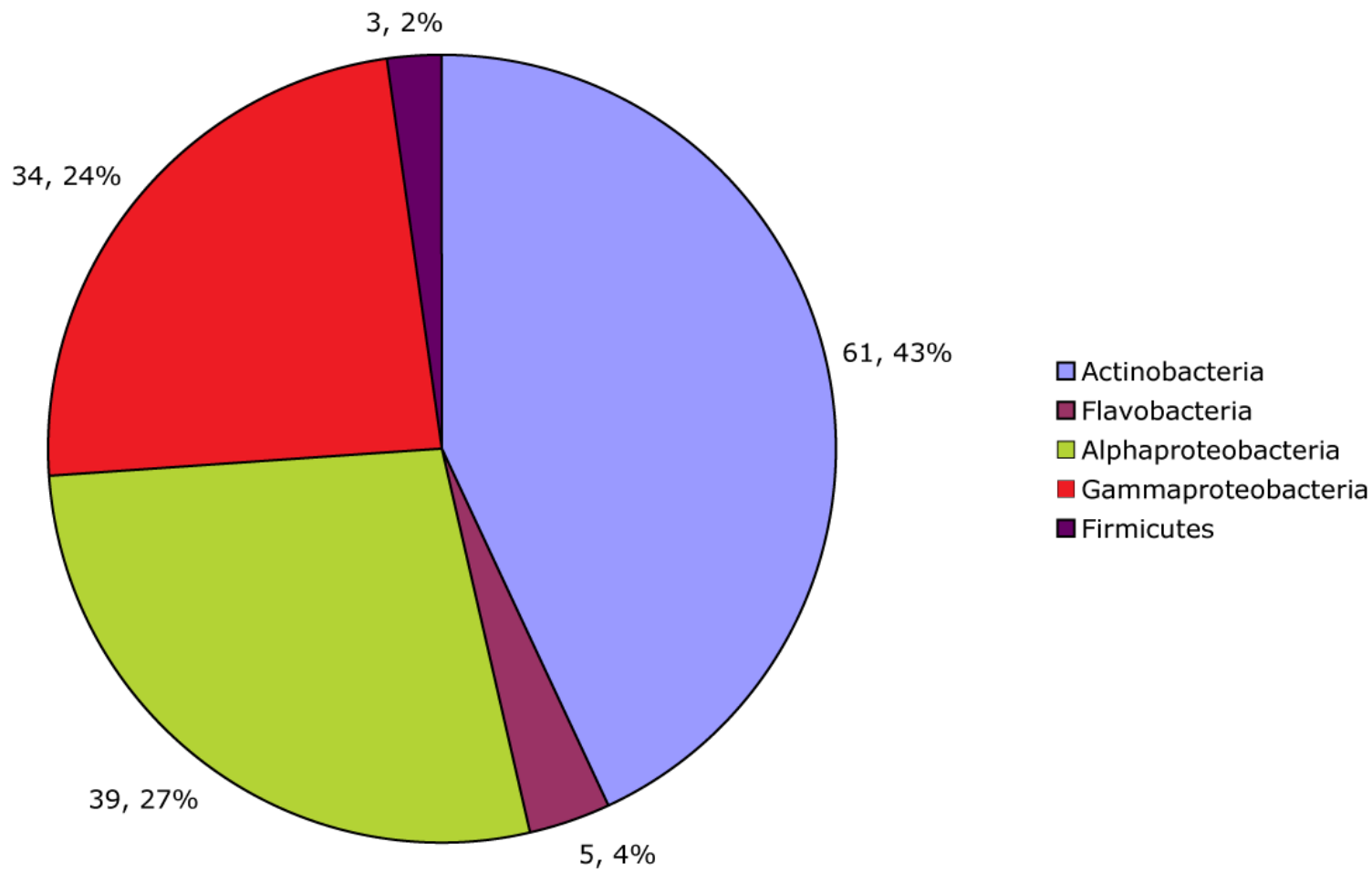

Figure 4. Class-level distribution of isolates obtained in this study. Values next to each wedge of the chart indicate the number of isolates in the category, followed by the percentage of the total. 
Figure 5. Phylogenetic trees detailing the relationships between isolates obtained in this study and other cultured and uncultured organisms deposited in GenBank. Trees were constructed using the Neighbor Joining algorithm in ARB and bootstrapped 1000 times using the neighbor joining algorithm within Phylip (v 3.68). Asterisks indicate $70 \%$ or greater bootstrap confidence. Sequences have been organized in one of four trees: (a) Alphaproteobacteria (b) Gammaproteobacteria (c) Actinobacteria (d) Firmicutes and Bacteroidetes. 


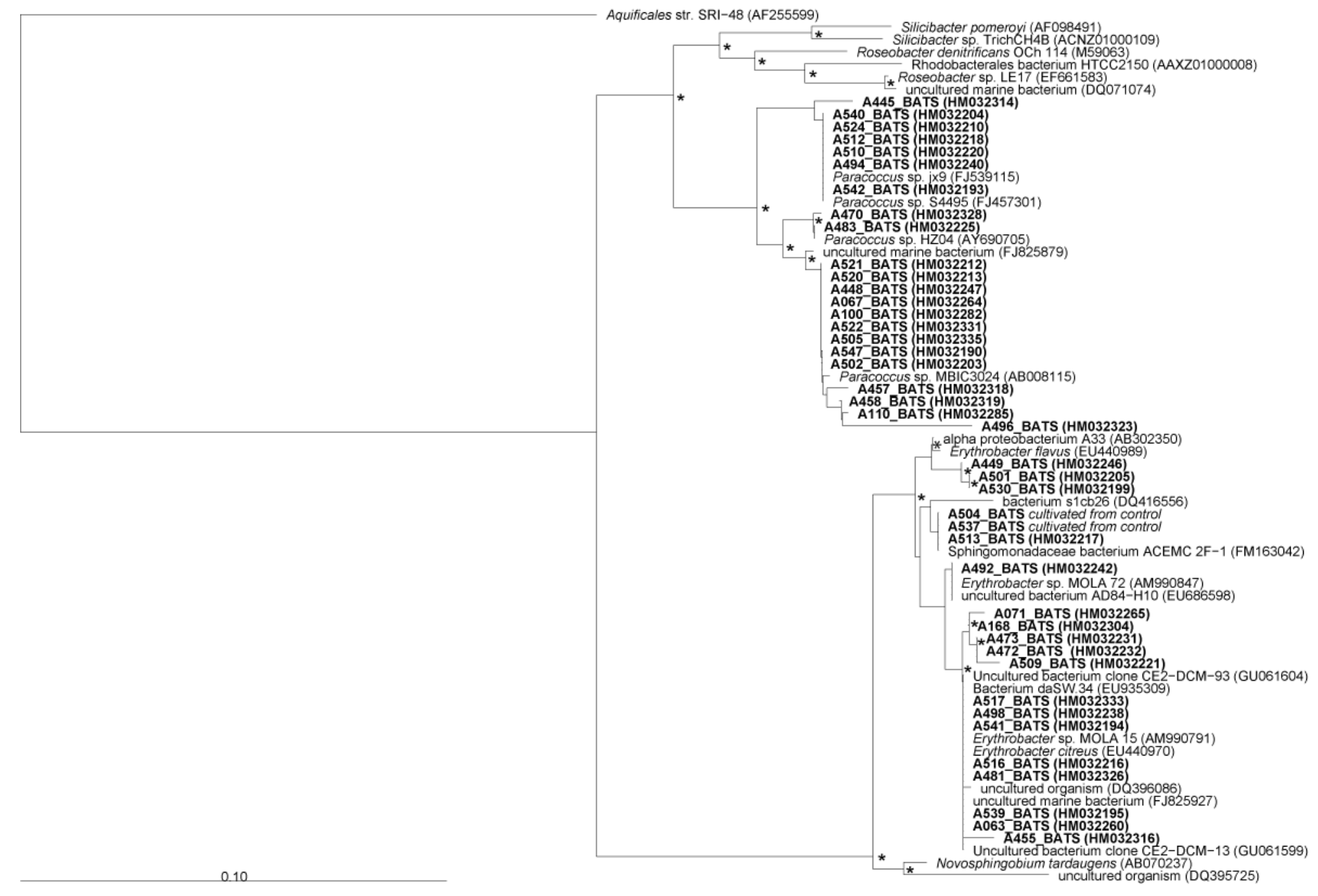

Figure 5a 


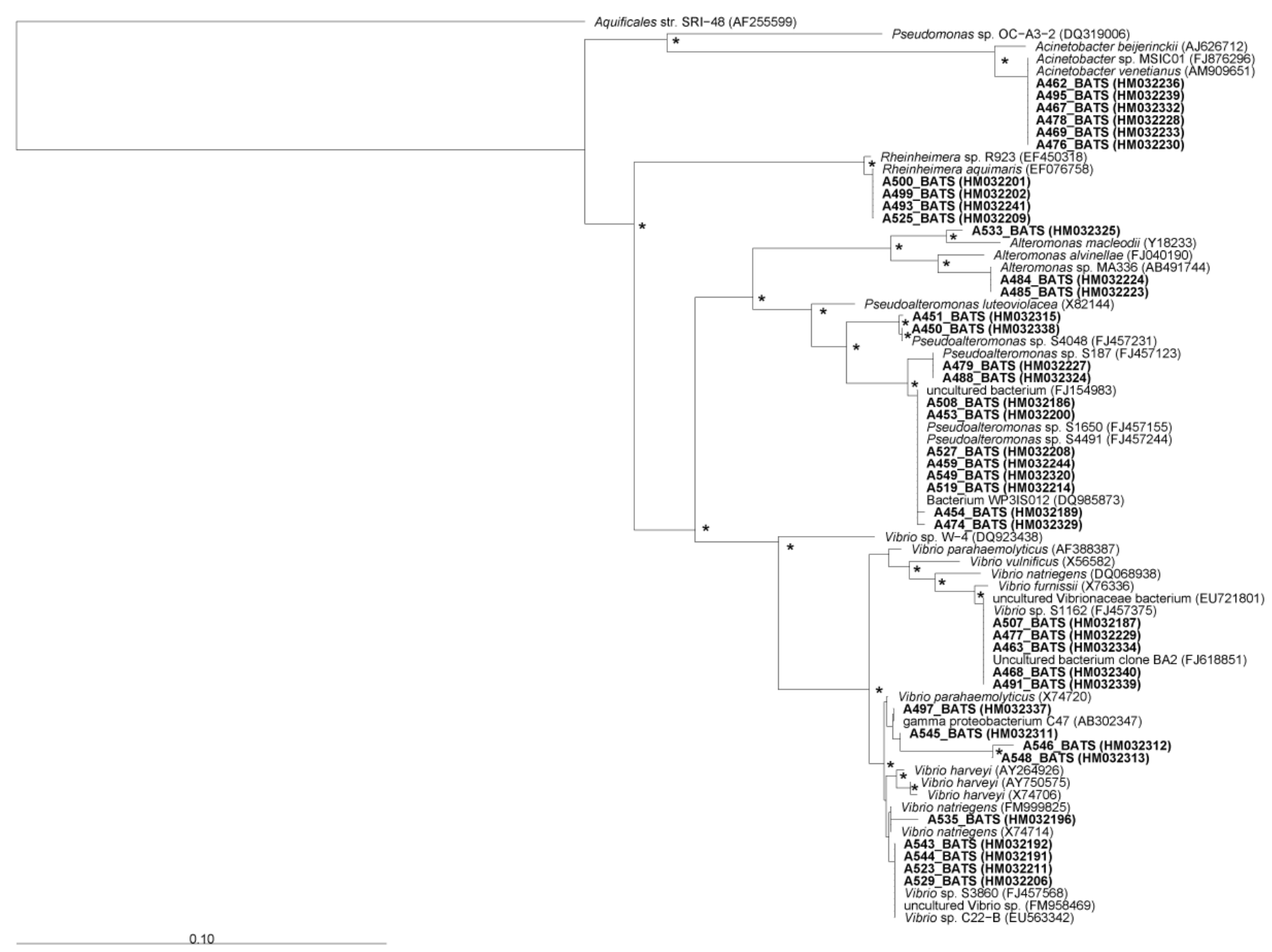

Figure 5b 


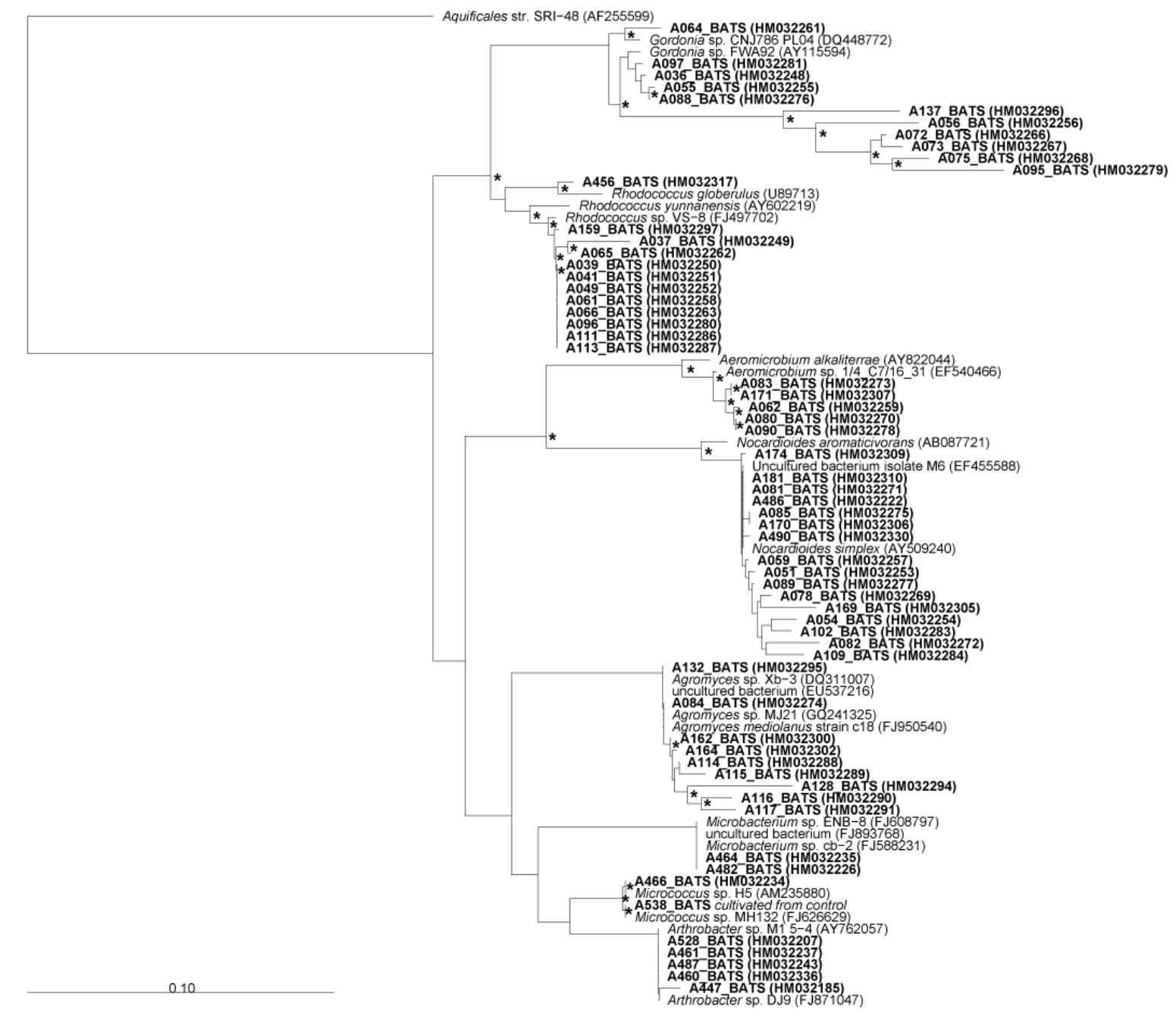

Figure 5c 


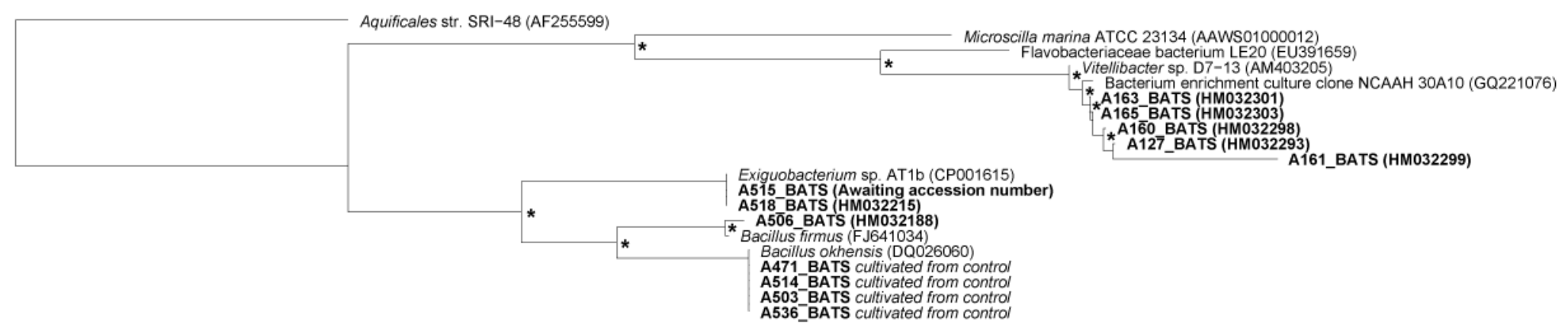

Figure 5d 


\begin{tabular}{|c|c|}
\hline Isolate & AHLs \\
\hline $\mathrm{A} 071$ & n.t. \\
$\mathrm{A} 072$ & - \\
$\mathrm{A} 111$ & - \\
$\mathrm{A} 113$ & n.t. \\
$\mathrm{A} 463$ & - \\
$\mathrm{A} 468$ & + \\
$\mathrm{A} 477$ & + \\
$\mathrm{A} 484$ & - \\
$\mathrm{A} 492$ & - \\
$\mathrm{A} 491$ & + \\
$\mathrm{A} 507$ & + \\
$\mathrm{A} 513$ & + \\
$\mathrm{A} 537$ & + \\
$\mathrm{A} 541$ & + \\
\hline
\end{tabular}

Table 1. Biosensor hit table. Isolates listed in this table induced a blue spot on the $A$. tumefaciens NTL4 bioassay which indicates they produce substances with the bioactivity of AHLs. These isolates were subsequently screened by LCQ-MS unless indicated (nottested, n.t.). A plus sign (+) indicated we detected AHLs by HPLC-MS where as a minus sign (-) indicates that we did not detect AHLs by HPLC-MS. 


\begin{tabular}{|c|c|c|c|c|c|c|c|c|c|}
\hline Isolate ID & Nearest GenBank match (PSI) & $30 c 8$ & $30 C 9$ & $30 C 10$ & $30 c 11$ & $30 C 12$ & C12 & C13 & C14 \\
\hline A507 & Vibrio vulnificus strain MP-4 (100\%) & -- & $\checkmark$ & $\checkmark$ & $\checkmark$ & $\checkmark$ & trace & -- & -- \\
\hline$\overline{\mathrm{A} 468}$ & Vibrio vulnificus strain MP-4 (100\%) & $\bar{d}$ & $\bar{d}$ & $\bar{d}$ & $\bar{\checkmark}$ & $\bar{d}$ & -- & $\overline{--}$ & $\overline{--}$ \\
\hline$\overline{\mathrm{A} 491}$ & Vibrio vulnificus strain MP-4 (99\%) & $\bar{d}$ & $\bar{d}$ & $\bar{\checkmark}$ & $\bar{\checkmark}$ & $\bar{v}$ & trace & $\overline{--}$ & -- \\
\hline$\overline{A 477}$ & Vibrio vulnificus strain MP-4 $(100 \%)$ & trace & $\bar{v}$ & $\bar{\checkmark}$ & $\bar{d}$ & $\bar{d}$ & trace & $\overline{--}$ & -- \\
\hline A463 & Vibrio sp. S1162 (99\%) & trace & $\sqrt{2}$ & $\sqrt{2}$ & $\sqrt{2}$ & -- & -- & -- & -- \\
\hline A537 & Erythrobacter vulgaris strain $0222-10(100 \%)$ & trace & $\overline{--}$ & -- & -- & $\overline{--}$ & -- & $\overline{--}$ & $\overline{--}$ \\
\hline$\overline{\mathrm{A} 541}$ & Erythrobacter citreus strain PR52-9 (100\%) & -- & $\overline{--}$ & -- & -- & -- & $\checkmark$ & $\bar{d}$ & $\checkmark$ \\
\hline$\overline{A 513}$ & Erythrobacter vulgaris strain $0222-10(100 \%)$ & -- & $\overline{--}$ & $\overline{--}$ & $\overline{--}$ & -- & $\bar{\checkmark}$ & $\bar{d}$ & $\checkmark$ \\
\hline
\end{tabular}

Table 2. Table of AHLs detected in isolates. Next to each isolate ID is the identity of the nearest GenBank match with the percent sequence identity (PSI) in parentheses. If a peak of approximately three times the height of the baseline is present (considered to be an 'integratable' peak), the compound is marked with a check mark $(\checkmark)$. If the compound is detectable although in a quantity which is less than the latter threshold, the compound is considered 'trace'.

Supplemental Table 1. Nearest GenBank neighbors of cultivars isolated at BATS from fresh Trichodesmium colonies.

Isolates are organized by the particular colony from which they were cultivated. 


\begin{tabular}{|c|c|c|c|c|c|c|c|c|}
\hline Isolate ID & $\begin{array}{l}\text { Source } \\
\text { colony }\end{array}$ & Accession no. & Sequence ID of nearest BLAST match & $\begin{array}{c}\text { Accession } \\
\text { no. (BLAST } \\
\text { match) }\end{array}$ & PSI & $\begin{array}{c}\text { Number of } \\
\text { bases } \\
\text { compared }\end{array}$ & $\begin{array}{c}\text { Bit } \\
\text { score }\end{array}$ & Lineage \\
\hline A471 & control, 4 & not assigned & $\begin{array}{l}\text { Bacillus okhensis strain Kh10-101 16S ribosomal RNA } \\
\text { gene }\end{array}$ & DQ026060 & 100 & 755 & 755 & Bacteria; Firmicutes; Bacillales; Bacillaceae; Bacillus \\
\hline A503 & control, 4 & not assigned & $\begin{array}{l}\text { Bacillus okhensis strain Kh10-101 16S ribosomal RNA } \\
\text { gene }\end{array}$ & DQ026060 & 99 & 715 & 715 & Bacteria; Firmicutes; Bacillales; Bacillaceae; Bacillus \\
\hline A504 & control, 4 & not assigned & $\begin{array}{l}\text { Sphingomonadaceae bacterium ACEMC } 2 \mathrm{~F}-1 \text { partial } 16 \mathrm{~S} \\
\text { rRNA gene, isolate ACEMC } 2 \mathrm{~F}-1\end{array}$ & FM163042 & 100 & 736 & 736 & $\begin{array}{l}\text { Bacteria; Proteobacteria; Alphaproteobacteria; } \\
\text { Sphingomonadales;Sphingomonadaceae }\end{array}$ \\
\hline A513 & control, 4 & not assigned & $\begin{array}{l}\text { Sphingomonadaceae bacterium ACEMC } 2 \mathrm{~F}-1 \text { partial } 16 \mathrm{~S} \\
\text { rRNA gene, isolate ACEMC } 2 \mathrm{~F}-1\end{array}$ & FM163042 & 100 & 741 & 741 & $\begin{array}{l}\text { Bacteria; Proteobacteria; Alphaproteobacteria; } \\
\text { Sphingomonadales; Sphingomonadaceae }\end{array}$ \\
\hline A514 & control, 4 & not assigned & $\begin{array}{l}\text { Bacillus okhensis strain Kh10-101 16S ribosomal RNA } \\
\text { gene }\end{array}$ & DQ026060 & 99 & 732 & 732 & Bacteria; Firmicutes; Bacillales; Bacillaceae; Bacillus \\
\hline A536 & control, 4 & not assigned & $\begin{array}{l}\text { Bacillus okhensis strain Kh10-101 16S ribosomal RNA } \\
\text { gene }\end{array}$ & DQ026060 & 100 & 739 & 739 & Bacteria; Firmicutes; Bacillales; Bacillaceae; Bacillus \\
\hline A537 & control, 4 & not assigned & $\begin{array}{l}\text { Sphingomonadaceae bacterium ACEMC } 2 \mathrm{~F}-1 \text { partial } 16 \mathrm{~S} \\
\text { rRNA gene, isolate ACEMC } 2 \mathrm{~F}-1\end{array}$ & FM163042 & 100 & 756 & 756 & $\begin{array}{l}\text { Bacteria; Proteobacteria; Alphaproteobacteria; } \\
\text { Sphingomonadales;Sphingomonadaceae }\end{array}$ \\
\hline A538 & control, 4 & not assigned & Micrococcus sp. MH132 16S ribosomal RNA gene & FJ626629 & 100 & 753 & 753 & $\begin{array}{l}\text { Bacteria; Actinobacteria; Actinobacteridae; Actinomycetales; } \\
\text { Micrococcineae; Micrococcaceae; Micrococcus }\end{array}$ \\
\hline A449 & puff, 5 & HM032246 & $\begin{array}{l}\text { Erythrobacter flavus strain 2PR56-3 16S ribosomal RNA } \\
\text { gene }\end{array}$ & EU440989 & 98 & 698 & 699 & $\begin{array}{l}\text { Bacteria; Proteobacteria; Alphaproteobacteria; } \\
\text { Sphingomonadales; Erythrobacteraceae; Erythrobacter }\end{array}$ \\
\hline A450 & puff, 5 & HМ032338 & Pseudoalteromonas sp. S4048 $16 \mathrm{~S}$ ribosomal RNA gene & FJ457231 & 100 & 557 & 557 & $\begin{array}{l}\text { Bacteria; Proteobacteria; Gammaproteobacteria; } \\
\text { Alteromonadales; Pseudoalteromonadaceae; Pseudoalteromonas }\end{array}$ \\
\hline A472 & puff, 5 & HM032232 & $\begin{array}{l}\text { Uncultured marine bacterium clone BM1-4-49 16S } \\
\text { ribosomal RNA }\end{array}$ & FJ825879 & 99 & 715 & 715 & 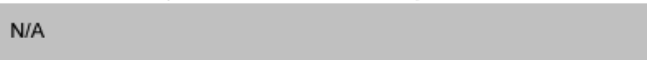 \\
\hline A472 & puff, 5 & HM032232 & $\begin{array}{l}\text { Erythrobacter citreus strain PR52-9 } 16 \mathrm{~S} \text { ribosomal RNA } \\
\text { gene }\end{array}$ & EU440970 & 99 & 715 & 715 & $\begin{array}{l}\text { Bacteria; Proteobacteria; Alphaproteobacteria; } \\
\text { Sphingomonadales; Erythrobacteraceae; Erythrobacter }\end{array}$ \\
\hline A473 & puff, 5 & HM032231 & $\begin{array}{l}\text { Uncultured marine bacterium clone BM1-4-49 16S } \\
\text { ribosomal RNA }\end{array}$ & FJ825879 & 99 & 730 & 730 & N/A \\
\hline A473 & puff, 5 & HM032231 & $\begin{array}{l}\text { Erythrobacter citreus strain PR52-9 16S ribosomal RNA } \\
\text { gene }\end{array}$ & EU440970 & 99 & 730 & 730 & $\begin{array}{l}\text { Bacteria; Proteobacteria; Alphaproteobacteria; } \\
\text { Sphingomonadales; Erythrobacteraceae; Erythrobacter }\end{array}$ \\
\hline A474 & puff, 6 & HM032329 & Pseudoalteromonas sp. S1650 16S ribosomal RNA gene & FJ457155 & 99 & 600 & 600 & $\begin{array}{l}\text { Bacteria; Proteobacteria; Gammaproteobacteria; Alteromonadales; } \\
\text { Pseudoalteromonadacea; Pseudoalteromonas }\end{array}$ \\
\hline A476 & puff, 6 & HM032230 & Acinetobacter sp. MSIC01 16S ribosomal RNA gene & FJ876296 & 99 & 777 & 778 & $\begin{array}{l}\text { Bacteria; Proteobacteria; Gammaproteobacteria; Pseudomonadales; } \\
\text { Moraxellaceae; Acinetobacte }\end{array}$ \\
\hline A477 & puff, 6 & HM032229 & $\begin{array}{l}\text { Uncultured Vibrionaceae bacterium clone D004023G01 } \\
16 \mathrm{~S}\end{array}$ & EU721801 & 100 & 739 & 739 & 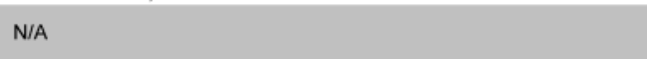 \\
\hline A477 & puff, 6 & HM032229 & Vibrio sp. S1162 16 S ribosomal RNA gene & FJ457375 & 100 & 739 & 739 & $\begin{array}{l}\text { Bacteria; Proteobacteria; Gammaproteobacteria; } \\
\text { Vibrionales;Vibrionaceae; Vibrio }\end{array}$ \\
\hline A498 & puff, 9 & HM032238 & $\begin{array}{l}\text { Uncultured marine bacterium clone BM1-4-49 16S } \\
\text { ribosomal RNA }\end{array}$ & FJ825879 & 99 & 736 & 736 & 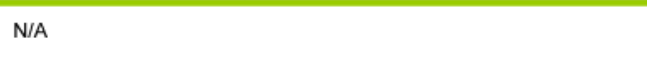 \\
\hline A498 & puff, 9 & HM032238 & $\begin{array}{l}\text { Erythrobacter citreus strain PR52-9 } 16 \text { S ribosomal RNA } \\
\text { gene }\end{array}$ & EU440970 & 99 & 736 & 736 & $\begin{array}{l}\text { Bacteria; Proteobacteria; Alphaproteobacteria; } \\
\text { Sphingomonadales; Erythrobacteraceae; Erythrobacter }\end{array}$ \\
\hline A499 & puff, 9 & HM032202 & $\begin{array}{l}\text { Rheinheimera sp. R923 } 16 \text { S small subunit ribosomal RNA } \\
\text { gene }\end{array}$ & $\mathrm{EF} 450318$ & 99 & 690 & 690 & $\begin{array}{l}\text { Bacteria; Proteobacteria; Gammaproteobacteria; } \\
\text { Chromatiales;Chromatiaceae; Rheinheimera }\end{array}$ \\
\hline A500 & puff, 9 & HM032201 & $\begin{array}{l}\text { Rheinheimera aquimaris strain SW-369 } 16 \mathrm{~S} \text { ribosomal } \\
\text { RNA gene }\end{array}$ & EF076758 & 99 & 723 & 725 & $\begin{array}{l}\text { Bacteria; Proteobacteria; Gammaproteobacteria; } \\
\text { Chromatiales;Chromatiaceae; Rheinheimera }\end{array}$ \\
\hline A501 & puff, 9 & HM032205 & Alpha proteobacterium A33 gene for $16 \mathrm{~S}$ rRNA & AB302350 & 99 & 706 & 703 & Bacteria; Proteobacteria; Alphaproteobacteria \\
\hline A502 & puff, 9 & HM032203 & Paracoccus sp. MBIC3024 gene for $16 \mathrm{~S}$ rRNA & AB008115 & 99 & 711 & 711 & $\begin{array}{l}\text { Bacteria; Proteobacteria; Alphaproteobacteria; } \\
\text { Rhodobacterales; Rhodobacteraceae; Paracoccus }\end{array}$ \\
\hline A520 & puff, 9 & HM032213 & Paracoccus sp. MBIC3024 gene for $16 \mathrm{~S}$ rRNA & AB008115 & 99 & 737 & 737 & $\begin{array}{l}\text { Bacteria; Proteobacteria; Alphaproteobacteria; } \\
\text { Rhodobacterales; Rhodobacteraceae; Paracoccus }\end{array}$ \\
\hline A521 & puff, 9 & HM032212 & Paracoccus sp. MBIC3024 gene for $16 \mathrm{~S}$ rRNA & AB008115 & 99 & 733 & 733 & $\begin{array}{l}\text { Bacteria; Proteobacteria; Alphaproteobacteria; } \\
\text { Rhodobacterales; Rhodobacteraceae; Paracoccus }\end{array}$ \\
\hline
\end{tabular}




\begin{tabular}{|c|c|c|c|c|c|c|c|c|}
\hline Isolate ID & $\begin{array}{l}\text { Source } \\
\text { colony }\end{array}$ & Accession no. & Sequence ID of nearest BLAST match & $\begin{array}{c}\text { Accession } \\
\text { no. (BLAST } \\
\text { match) }\end{array}$ & PSI & $\begin{array}{c}\begin{array}{c}\text { Number of } \\
\text { bases } \\
\text { compared }\end{array} \\
\end{array}$ & $\begin{array}{c}\text { Bit } \\
\text { score }\end{array}$ & Lineage \\
\hline A522 & puff, 9 & HM032331 & Paracoccus sp. MBIC3024 gene for $16 \mathrm{~S}$ rRNA & AB008115 & 99 & 889 & 890 & $\begin{array}{l}\text { Bacteria; Proteobacteria; Alphaproteobacteria; } \\
\text { Rhodobacterales; Rhodobacteraceae; Paracoccus }\end{array}$ \\
\hline A460 & tuft, 1 & HМ032336 & Arthrobacter sp. DJ9 $16 \mathrm{~S}$ ribosomal RNA gene & FJ871047 & 100 & 805 & 805 & $\begin{array}{l}\text { Bacteria; Actinobacteria; Actinobacteridae; } \\
\text { Actinomycetales; Micrococcineae; Micrococcaceae; Arthrobacter }\end{array}$ \\
\hline A461 & tuft, 1 & HМ032237 & Arthrobacter sp. DJ9 $16 \mathrm{~S}$ ribosomal RNA gene & FJ871047 & 100 & 723 & 723 & $\begin{array}{l}\text { Bacteria; Actinobacteria; Actinobacteridae; } \\
\text { Actinomycetales;:Micrococcineae; Micrococcaceae; Arthrobacter }\end{array}$ \\
\hline A462 & tuft, 1 & HМ032236 & Acinetobacter sp. MSIC01 $16 \mathrm{~S}$ ribosomal RNA gene & FJ876296 & 100 & 722 & 722 & $\begin{array}{l}\text { Bacteria; Proteobacteria; Gammaproteobacteria; Pseudomonadales; } \\
\text { Moraxellaceae; Acinetobacte }\end{array}$ \\
\hline A463 & tuft, 1 & HM032334 & $\begin{array}{l}\text { Uncultured Vibrionaceae bacterium clone D004023G01 } \\
16 \mathrm{~S}\end{array}$ & EU721801 & 99 & 808 & 809 & 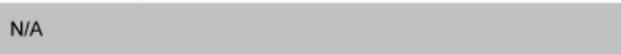 \\
\hline A463 & tuft, 1 & HМ032334 & Vibrio sp. S1162 16 S ribosomal RNA gene & FJ457375 & 99 & 808 & 809 & $\begin{array}{l}\text { Bacteria; Proteobacteria; Gammaproteobacteria; } \\
\text { Vibrionales;Vibrionaceae; Vibrio }\end{array}$ \\
\hline A464 & tuft, 1 & HМ032235 & $\begin{array}{l}\text { Uncultured bacterium clone nbt35b03 } 16 \mathrm{~S} \text { ribosomal RNA } \\
\text { gene }\end{array}$ & FJ893768 & 99 & 761 & 761 & N/A \\
\hline A464 & tuft, 1 & HM032235 & Microbacterium sp. cb-2 $16 \mathrm{~S}$ ribosomal RNA gene & FJ588231 & 99 & 761 & 761 & $\begin{array}{l}\text { Bacteria; Actinobacteria; Actinobacteridae; } \\
\text { Actinomycetales; Micrococcineae; Microbacteriaceae; Microbacterium }\end{array}$ \\
\hline A509 & tuft, 10 & HМ032221 & $\begin{array}{l}\text { Uncultured marine bacterium clone BM1-4-49 } 16 \mathrm{~S} \\
\text { ribosomal RNA }\end{array}$ & FJ825879 & 99 & 621 & 621 & 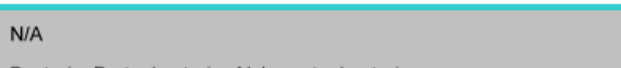 \\
\hline A509 & tuft, 10 & HM032221 & Erythrobacter sp. MOLA 15 partial 16S rRNA gene & AM990791 & 99 & 621 & 621 & $\begin{array}{l}\text { Bacteria; Proteobacteria; Alphaproteobacteria; } \\
\text { Sphingomonadales; Erythrobacteraceae; Erythrobacter }\end{array}$ \\
\hline A510 & tuft, 10 & HМ032220 & Paracoccus sp. jx9 16S ribosomal RNA gene & FJ539115 & 99 & 690 & 690 & $\begin{array}{l}\text { Bacteria; Proteobacteria; Alphaproteobacteria; } \\
\text { Rhodobacterales; Rhodobacteraceae; Paracoccus }\end{array}$ \\
\hline A511 & tuft, 10 & HМ032219 & $\begin{array}{l}\text { Uncultured marine bacterium clone BM1-4-49 } 16 \mathrm{~S} \\
\text { ribosomal RNA }\end{array}$ & FJ825879 & 99 & 644 & 640 & (1) \\
\hline A511 & tuft, 10 & HМ032219 & Erythrobacter sp. MOLA 15 partial 16S rRNA gene & AM990791 & 99 & 644 & 640 & $\begin{array}{l}\text { Bacteria; Proteobacteria; Alphaproteobacteria; } \\
\text { Sphingomonadales; Erythrobacteraceae; Erythrobacter }\end{array}$ \\
\hline A512 & tuft, 10 & HM032218 & Paracoccus sp. jx9 16S ribosomal RNA gene & FJ539115 & 100 & 695 & 695 & $\begin{array}{l}\text { Bacteria; Proteobacteria; Alphaproteobacteria; } \\
\text { Rhodobacterales; Rhodobacteraceae; Paracoccus }\end{array}$ \\
\hline A516 & tuft, 10 & HM032216 & $\begin{array}{l}\text { Uncultured marine bacterium clone BM1-4-49 } 16 \mathrm{~S} \\
\text { ribosomal RNA gene }\end{array}$ & FJ825927 & 100 & 730 & 730 & 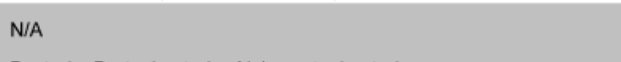 \\
\hline A516 & tuft, 10 & HМ032216 & $\begin{array}{l}\text { Erythrobacter citreus strain PR52-9 16S ribosomal RNA } \\
\text { gene }\end{array}$ & EU440970 & 100 & 730 & 730 & $\begin{array}{l}\text { Bacteria; Proteobacteria; Alphaproteobacteria; } \\
\text { Sphingomonadales; Erythrobacteraceae; Erythrobacter }\end{array}$ \\
\hline A517 & tuft, 10 & HМ032333 & $\begin{array}{l}\text { Uncultured marine bacterium clone BM1-4-49 16S } \\
\text { ribosomal RNA }\end{array}$ & FJ825927 & 100 & 873 & 873 & 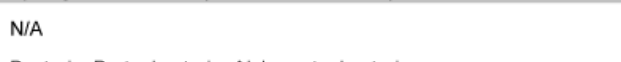 \\
\hline A517 & tuft, 10 & HМ032333 & $\begin{array}{l}\text { Erythrobacter citreus strain PR52-9 16S ribosomal RNA } \\
\text { gene }\end{array}$ & EU440970 & 100 & 873 & 873 & $\begin{array}{l}\text { Bacteria; Proteobacteria; Alphaproteobacteria; } \\
\text { Sphingomonadales; Erythrobacteraceae; Erythrobacter }\end{array}$ \\
\hline A530 & tuft, 10 & HM032199 & Alpha proteobacterium A33 gene for $16 \mathrm{~S}$ rRNA & AB302350 & 98 & 725 & 727 & Bacteria; Proteobacteria; Alphaproteobacteria. \\
\hline A531 & tuft, 10 & HM032198 & $\begin{array}{l}\text { Uncultured marine bacterium clone BM1-4-49 16S } \\
\text { ribosomal RNA }\end{array}$ & FJ825927 & 100 & 574 & 574 & $\mathrm{~N} / \mathrm{A}$ \\
\hline A531 & tuft, 10 & HM032198 & Erythrobacter sp. MOLA 15 partial 16S rRNA gene & EU440970 & 100 & 574 & 574 & $\begin{array}{l}\text { Bacteria; Proteobacteria; Alphaproteobacteria; } \\
\text { Sphingomonadales; Erythrobacteraceae; Erythrobacter }\end{array}$ \\
\hline A532 & tuft, 10 & HM032327 & $\begin{array}{l}\text { Uncultured marine bacterium clone BM1-4-49 } 16 \mathrm{~S} \\
\text { ribosomal RNA }\end{array}$ & FJ825927 & 99 & 764 & 764 & N/A \\
\hline A532 & tuft, 10 & HM032327 & Erythrobacter sp. MOLA 15 partial $16 \mathrm{~S}$ rRNA gene & EU440970 & 99 & 764 & 764 & $\begin{array}{l}\text { Bacteria; Proteobacteria; Alphaproteobacteria; } \\
\text { Sphingomonadales; Erythrobacteraceae; Erythrobacter }\end{array}$ \\
\hline A533 & tuft, 10 & HM032325 & Alteromonas macleodii $16 \mathrm{~S}$ rRNA gene, strain $\mathrm{CH}-460$ & Y18233 & 97 & 867 & 855 & $\begin{array}{l}\text { Bacteria; Proteobacteria; Gammaproteobacteria; } \\
\text { Alteromonadales;Alteromonadaceae; Alteromonas }\end{array}$ \\
\hline
\end{tabular}




\begin{tabular}{|c|c|c|c|c|c|c|c|c|}
\hline Isolate ID & $\begin{array}{l}\text { Source } \\
\text { colony }\end{array}$ & Accession no. & Sequence ID of nearest BLAST match & $\begin{array}{c}\text { Accession } \\
\text { no. (BLAST } \\
\text { match) }\end{array}$ & PSI & $\begin{array}{c}\begin{array}{c}\text { Number of } \\
\text { bases } \\
\text { compared }\end{array} \\
\end{array}$ & $\begin{array}{c}\text { Bit } \\
\text { score }\end{array}$ & Lineage \\
\hline A534 & tuft, 10 & HМ032197 & $\begin{array}{l}\text { Uncultured marine bacterium clone BM1-4-49 } 16 \mathrm{~S} \\
\text { ribosomal RNA }\end{array}$ & FJ825879 & 100 & 586 & 586 & N/A \\
\hline A534 & tuft, 10 & HM032197 & Erythrobacter sp. MOLA 15 partial $16 \mathrm{~S}$ rRNA gene & AM990791 & 100 & 586 & 586 & $\begin{array}{l}\text { Bacteria; Proteobacteria; Alphaproteobacteria; } \\
\text { Sphingomonadales; Erythrobacteraceae; Erythrobacter }\end{array}$ \\
\hline A539 & tuft, 10 & HM032195 & $\begin{array}{l}\text { Uncultured marine bacterium clone BM1-4-49 16S RNA } \\
\text { gene }\end{array}$ & FJ825879 & 100 & 733 & 733 & N/A \\
\hline A539 & tuft, 10 & HM032195 & $\begin{array}{l}\text { Erythrobacter citreus strain PR } 52-916 \text { S ribosomal RNA } \\
\text { gene }\end{array}$ & EU440970 & 100 & 733 & 733 & $\begin{array}{l}\text { Bacteria; Proteobacteria; Alphaproteobacteria; } \\
\text { Sphingomonadales; Erythrobacteraceae; Erythrobacter }\end{array}$ \\
\hline A540 & tuft, 10 & HM032204 & Paracoccus sp. S4495 16S ribosomal RNA gene & FJ457301 & 100 & 758 & 758 & $\begin{array}{l}\text { Bacteria; Proteobacteria; Alphaproteobacteria; } \\
\text { Rhodobacterales;Rhodobacteraceae; Paracoccus }\end{array}$ \\
\hline A541 & tuft, 10 & HM032194 & $\begin{array}{l}\text { Uncultured marine bacterium clone BM1-4-49 16S RNA } \\
\text { gene }\end{array}$ & FJ825927 & 100 & 739 & 739 & 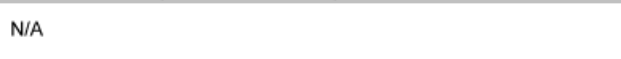 \\
\hline A541 & tuft, 10 & HM032194 & $\begin{array}{l}\text { Erythrobacter citreus strain PR52-9 } 16 \text { S ribosomal RNA } \\
\text { gene }\end{array}$ & EU440970 & 100 & 739 & 739 & $\begin{array}{l}\text { Bacteria; Proteobacteria; Alphaproteobacteria; } \\
\text { Sphingomonadales; Erythrobacteraceae; Erythrobacter }\end{array}$ \\
\hline A542 & tuft, 10 & HM032193 & Paracoccus sp. S4495 $16 \mathrm{~S}$ ribosomal RNA gene & FJ457301 & 100 & 740 & 740 & $\begin{array}{l}\text { Bacteria; Proteobacteria; Alphaproteobacteria; } \\
\text { Rhodobacterales; Rhodobacteraceae; Paracoccus }\end{array}$ \\
\hline A507 & tuft, 11 & HM032187 & Uncultured bacterium clone BA2 $16 \mathrm{~S}$ ribosomal RNA gene & FJ618851 & 100 & 711 & 711 & N/A \\
\hline A507 & tuft, 11 & HM032187 & Vibrio sp. S1162 $16 \mathrm{~S}$ ribosomal RNA gene & FJ457375 & 100 & 711 & 711 & $\begin{array}{l}\text { Bacteria; Proteobacteria; Gammaproteobacteria; } \\
\text { Vibrionales;Vibrionacea; Vibrio }\end{array}$ \\
\hline A508 & tuft, 11 & HM032186 & Uncultured bacterium clone AJ $16 \mathrm{~S}$ ribosomal RNA gene & FJ154983 & 99 & 684 & 684 & N/A \\
\hline A508 & tuft, 11 & HM032186 & $\begin{array}{l}\text { Pseudoalteromonas sp. OC-A5-12 } 16 \mathrm{~S} \text { ribosomal RNA } \\
\text { gene }\end{array}$ & DQ319006 & 99 & 684 & 684 & $\begin{array}{l}\text { Bacteria; Proteobacteria; Gammaproteobacteria; } \\
\text { Pseudomonadales;Pseudomonadaceae; Pseudomonas }\end{array}$ \\
\hline A515 & tuft, 11 & & Exiguobacterium sp. AT1b & CP001615 & 100 & 738 & 738 & $\begin{array}{l}\text { Bacteria; Firmicutes; Bacillales; Bacillales Family XII. Incertae;Sedis; } \\
\text { Exiguobacterium }\end{array}$ \\
\hline A518 & tuft, 11 & HM032215 & Exiguobacterium sp. AT1b & CP001615 & 100 & 760 & 760 & $\begin{array}{l}\text { Bacteria; Firmicutes; Bacillales; Bacillales Family XII. Incertae;Sedis; } \\
\text { Exiguobacterium }\end{array}$ \\
\hline A519 & tuft, 11 & HM032214 & Bacterium WP3IS012 16S ribosomal RNA gene & DQ985873 & 99 & 732 & 733 & \\
\hline A523 & tuft, 11 & HМ032211 & Uncultured Vibrio sp. partial $16 \mathrm{~S}$ rRNA gene, clone HG136 & FM958469 & 100 & 681 & 681 & N/A \\
\hline A523 & tuft, 11 & HМ032211 & Vibrio sp. S3860 $16 \mathrm{~S}$ ribosomal RNA gene & FJ457568 & 100 & 681 & 681 & $\begin{array}{l}\text { Bacteria; Proteobacteria; Gammaproteobacteria; } \\
\text { Vibrionales;Vibrionacea; Vibrio }\end{array}$ \\
\hline A527 & tuft, 11 & HM032208 & Pseudoalteromonas sp. S1650 16S ribosomal RNA gene & FJ457155 & 100 & 716 & 716 & $\begin{array}{l}\text { Bacteria; Proteobacteria; Gammaproteobacteria; Alteromonadales; } \\
\text { Pseudoalteromonadacea; Pseudoalteromonas }\end{array}$ \\
\hline A528 & tuft, 11 & HМ032207 & Arthrobacter sp. DJ9 $16 \mathrm{~S}$ ribosomal RNA gene & FJ871047 & 100 & 728 & 728 & $\begin{array}{l}\text { Bacteria; Actinobacteria; Actinobacteridae; } \\
\text { Actinomycetales;:Micrococcineae; Micrococcaceae; Arthrobacter }\end{array}$ \\
\hline A529 & tuft, 11 & HМ032206 & Uncultured Vibrio sp. partial $16 \mathrm{~S}$ rRNA gene, clone HG136 & FM958469 & 100 & 724 & 724 & N/A \\
\hline A529 & tuft, 11 & HM032206 & Vibrio sp. \$3860 16S ribosomal RNA gene & FJ457568 & 100 & 724 & 724 & $\begin{array}{l}\text { Bacteria; Proteobacteria; Gammaproteobacteria; } \\
\text { Vibrionales;Vibrionaceae; Vibrio }\end{array}$ \\
\hline A535 & tuft, 11 & HМ032196 & Vibrio natriegens partial $16 \mathrm{~S}$ rRNA gene, strain CECT 7466 & FM999825 & 99 & 683 & 683 & $\begin{array}{l}\text { Bacteria; Proteobacteria; Gammaproteobacteria; } \\
\text { Vibrionales:Vibrionaceae; Vibrio }\end{array}$ \\
\hline A497 & tuft, 2 & HM032337 & Gamma proteobacterium C47 gene for $16 \mathrm{~S}$ rRNA & AB302347 & 99 & 858 & 859 & Bacteria; Proteobacteria; Gammaproteobacteria \\
\hline A547 & tuft, 2 & HМ032337 & Paracoccus sp. MBIC 3024 gene for $16 \mathrm{~S}$ rRNA & AB008115 & 99 & 77 & 707 & $\begin{array}{l}\text { Bacteria; Proteobacteria; Alphaproteobacteria; } \\
\text { Rhodobacterales; Rhodobacteraceae; Paracoccus }\end{array}$ \\
\hline A448 & tuft, 3 & HM032247 & Paracoccus sp. MBIC3024 gene for $16 \mathrm{~S}$ rRNA & AB008115 & 99 & 767 & 767 & $\begin{array}{l}\text { Bacteria; Proteobacteria; Alphaproteobacteria; } \\
\text { Rhodobacterales; Rhodobacteraceae; Paracoccus }\end{array}$ \\
\hline A466 & tuft, 3 & HМ032234 & Micrococcus sp. $\mathrm{H} 5$ partial $16 \mathrm{~S}$ rRNA gene, strain $\mathrm{H} 5$ & AM235880 & 99 & 601 & 601 & $\begin{array}{l}\text { Bacteria; Actinobacteria; Actinobacteridae; Actinomycetales; } \\
\text { Micrococcineae; Micrococcaceae; Micrococcus }\end{array}$ \\
\hline
\end{tabular}




\begin{tabular}{|c|c|c|c|c|c|c|c|c|}
\hline Isolate ID & $\begin{array}{l}\text { Source } \\
\text { colony }\end{array}$ & Accession no. & Sequence ID of nearest BLAST match & $\begin{array}{c}\text { Accession } \\
\text { no. (BLAST } \\
\text { match) }\end{array}$ & PSI & $\begin{array}{c}\text { Number of } \\
\text { bases } \\
\text { compared }\end{array}$ & $\begin{array}{c}\text { Bit } \\
\text { score }\end{array}$ & Lineage \\
\hline A467 & tuft, 3 & HМ032332 & $\begin{array}{l}\text { Acinetobacter venetianus partial } 16 \mathrm{~S} \text { rRNA gene, strain } \\
\text { ACI555 }\end{array}$ & AM909651 & 100 & 772 & 772 & $\begin{array}{l}\text { Bacteria; Proteobacteria; Gammaproteobacteria; } \\
\text { Pseudomonadales; Moraxellaceae; Acinetobacter }\end{array}$ \\
\hline A468 & tuft, 3 & HМ032340 & $\begin{array}{l}\text { Uncultured Vibrionaceae bacterium clone D004023G01 } \\
16 \mathrm{~S}\end{array}$ & EU721801 & 100 & 752 & 752 & ( \\
\hline A468 & tuft, 3 & HM032340 & Vibrio sp. S1162 16 S ribosomal RNA gene & FJ457375 & 100 & 752 & 752 & $\begin{array}{l}\text { Bacteria; Proteobacteria; Gammaproteobacteria; } \\
\text { Vibrionales;Vibrionaceae; Vibrio }\end{array}$ \\
\hline A469 & tuft, 3 & НМ032233 & Acinetobacter sp. MSIC01 $16 \mathrm{~S}$ ribosomal RNA gene & FJ876296 & 100 & 741 & 741 & $\begin{array}{l}\text { Bacteria; Proteobacteria; Gammaproteobacteria; Pseudomonadales; } \\
\text { Moraxellaceae; Acinetobacte }\end{array}$ \\
\hline A470 & tuft, 3 & HМ032328 & Paracoccus sp. HZ04 16S ribosomal RNA gene & AY690705 & 99 & 830 & 831 & $\begin{array}{l}\text { Bacteria; Proteobacteria; Alphaproteobacteria; } \\
\text { Rhodobacterales;:Rhodobacteraceae; Paracoccus }\end{array}$ \\
\hline A453 & tuft, 7 & HM032200 & Pseudoalteromonas sp. S1650 16S ribosomal RNA gene & FJ457155 & 100 & 733 & 733 & $\begin{array}{l}\text { Bacteria; Proteobacteria; Gammaproteobacteria; Alteromonadales; } \\
\text { Pseudoalteromonadaceae; Pseudoalteromonas }\end{array}$ \\
\hline A454 & tuft, 7 & HM032189 & Pseudoalteromonas sp. S4491 16S ribosomal RNA gene & FJ457244 & 99 & 705 & 705 & $\begin{array}{l}\text { Bacteria; Proteobacteria; Gammaproteobacteria; Alteromonadales; } \\
\text { Pseudoalteromonadaceae; Pseudoalteromonas }\end{array}$ \\
\hline A478 & tuft, 7 & HМ032228 & Acinetobacter sp. MSIC01 $16 \mathrm{~S}$ ribosomal RNA gene & FJ876296 & 100 & 743 & 743 & $\begin{array}{l}\text { Bacteria; Proteobacteria; Gammaproteobacteria; Pseudomonadales; } \\
\text { Moraxellaceae; Acinetobacter }\end{array}$ \\
\hline A479 & tuft, 7 & HM032227 & Pseudoalteromonas sp. S187 $16 \mathrm{~S}$ ribosomal RNA gene & FJ457123 & 100 & 715 & 715 & $\begin{array}{l}\text { Bacteria; Proteobacteria; Gammaproteobacteria; Alteromonadales; } \\
\text { Pseudoalteromonadaceae; Pseudoalteromonas }\end{array}$ \\
\hline A481 & tuft, 7 & HМ032326 & $\begin{array}{l}\text { Uncultured marine bacterium clone BM1-4-49 } 16 \mathrm{~S} \\
\text { ribosomal RNA gene }\end{array}$ & FJ825927 & 99 & 812 & 812 & 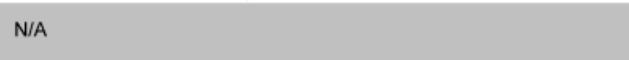 \\
\hline A481 & tuft, 7 & HM032326 & $\begin{array}{l}\text { Erythrobacter citreus strain PR } 52-9 \text { 16S ribosomal RNA } \\
\text { gene }\end{array}$ & EU440970 & 99 & 812 & 812 & $\begin{array}{l}\text { Bacteria; Proteobacteria; Alphaproteobacteria; } \\
\text { Sphingomonadales; Erythrobacteraceae; Erythrobacter }\end{array}$ \\
\hline A482 & tuft, 7 & HМ032226 & $\begin{array}{l}\text { Uncultured bacterium clone nbt35b03 16S ribosomal RNA } \\
\text { gene }\end{array}$ & FJ893768 & 100 & 722 & 722 & N/A \\
\hline A482 & tuft, 7 & HM032226 & Microbacterium sp. ENB-8 $16 \mathrm{~S}$ ribosomal RNA gene & FJ608797 & 100 & 722 & 722 & $\begin{array}{l}\text { Bacteria; Actinobacteria; Actinobacteridae; } \\
\text { Actinomycetales;Micrococcineae; Microbacteriaceae; Microbacterium }\end{array}$ \\
\hline A483 & tuft, 7 & HM032225 & Paracoccus sp. HZ04 $16 \mathrm{~S}$ ribosomal RNA gene & AY690705 & 100 & 730 & 730 & $\begin{array}{l}\text { Bacteria; Proteobacteria; Alphaproteobacteria; } \\
\text { Rhodobacterales; Rhodobacteraceae; Paracoccus }\end{array}$ \\
\hline A484 & tuft, 7 & HM032224 & Alteromonas sp. MA336 gene for $16 \mathrm{~S}$ rRNA & AB491744 & 100 & 717 & 717 & $\begin{array}{l}\text { Bacteria; Proteobacteria; Gammaproteobacteria; } \\
\text { Alteromonadales;Alteromonadaceae; Alteromonas }\end{array}$ \\
\hline A485 & tuft, 7 & HM032223 & Alteromonas sp. MA336 gene for $16 \mathrm{~S}$ rRNA & AB491744 & 100 & 725 & 725 & $\begin{array}{l}\text { Bacteria; Proteobacteria; Gammaproteobacteria; } \\
\text { Alteromonadales;Alteromonadaceae; Alteromonas }\end{array}$ \\
\hline A486 & tuft, 7 & HМ032222 & $\begin{array}{l}\text { Pimelobacter simplex strain S151 } 16 \text { S ribosomal RNA } \\
\text { gene }\end{array}$ & AY509240 & 100 & 724 & 724 & $\begin{array}{l}\text { Bacteria; Actinobacteria; Actinobacteridae; } \\
\text { Actinomycetales; Propionibacterineae; Nocardioidaceae; Pimelobacter }\end{array}$ \\
\hline A487 & tuft, 7 & HМ032243 & Arthrobacter sp. DJ9 $16 \mathrm{~S}$ ribosomal RNA gene & FJ871047 & 100 & 745 & 745 & $\begin{array}{l}\text { Bacteria; Actinobacteria; Actinobacteridae; } \\
\text { Actinomycetales;Micrococcineae; Micrococcaceae; Arthrobacter }\end{array}$ \\
\hline A488 & tuft, 7 & HM032324 & Pseudoalteromonas sp. S187 $16 \mathrm{~S}$ ribosomal RNA gene & FJ457123 & 99 & 843 & 843 & $\begin{array}{l}\text { Bacteria; Proteobacteria; Gammaproteobacteria; Alteromonadales; } \\
\text { Pseudoalteromonadaceae; Pseudoalteromonas }\end{array}$ \\
\hline A490 & tuft, 7 & НМ0з2330 & $\begin{array}{l}\text { Pimelobacter simplex strain S151 16S ribosomal RNA } \\
\text { gene }\end{array}$ & AY509240 & 99 & 683 & 683 & $\begin{array}{l}\text { Bacteria; Actinobacteria; Actinobacteridae; } \\
\text { Actinomycetales; Propionibacterineae; Nocardioidaceae; Pimelobacter }\end{array}$ \\
\hline A491 & tuft, 7 & HМ032339 & $\begin{array}{l}\text { Uncultured Vibrionaceae bacterium clone D004023G01 } \\
\text { 16S }\end{array}$ & EU721801 & 99 & 730 & 732 & 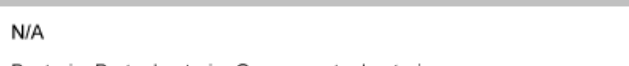 \\
\hline A491 & tuft, 7 & НМ032339 & Vibrio sp. S1162 $16 S$ ribosomal RNA gene & FJ457375 & 99 & 730 & 732 & $\begin{array}{l}\text { Bacteria; Proteobacteria; Gammaproteobacteria; } \\
\text { Vibrionales;Vibrionaceae; Vibrio }\end{array}$ \\
\hline A492 & tuft, 7 & HM032242 & Uncultured bacterium AD84-H10 genomic sequence & EU686598 & 100 & 727 & 727 & N/A \\
\hline A492 & tuft, 7 & HM032242 & Erythrobacter sp. MOLA 72 partial $16 \mathrm{~S}$ rRNA gene & AM990847 & 100 & 727 & 727 & $\begin{array}{l}\text { Bacteria; Proteobacteria; Alphaproteobacteria; } \\
\text { Sphingomonadales; Sphingomonadaceae }\end{array}$ \\
\hline
\end{tabular}




\begin{tabular}{|c|c|c|c|c|c|c|c|c|}
\hline Isolate ID & $\begin{array}{l}\text { Source } \\
\text { colony }\end{array}$ & Accession no. & Sequence ID of nearest BLAST match & $\begin{array}{c}\text { Accession } \\
\text { no. (BLAST } \\
\text { match) }\end{array}$ & PSI & $\begin{array}{c}\text { Number of } \\
\text { bases } \\
\text { compared }\end{array}$ & $\begin{array}{c}\text { Bit } \\
\text { score }\end{array}$ & Lineage \\
\hline A493 & tuft, 7 & HM032241 & $\begin{array}{l}\text { Rheinheimera aquimaris strain SW-369 } 16 \mathrm{~S} \text { ribosomal } \\
\text { RNA gene }\end{array}$ & EF076758 & 99 & 772 & 774 & $\begin{array}{l}\text { Bacteria; Proteobacteria; Gammaproteobacteria; } \\
\text { Chromatiales;Chromatiaceae; Rheinheimera }\end{array}$ \\
\hline A505 & tuft, 7 & HM032335 & Paracoccus sp. MBIC3024 gene for $16 \mathrm{~S}$ rRNA & AB008115 & 99 & 740 & 741 & $\begin{array}{l}\text { Bacteria; Proteobacteria; Alphaproteobacteria; } \\
\text { Rhodobacterales;:Rhodobacteraceae; Paracoccus }\end{array}$ \\
\hline A506 & tuft, 7 & HM032188 & $\begin{array}{l}\text { Bacillus firmus strain IMAUB1032 } 16 \mathrm{~S} \text { ribosomal RNA } \\
\text { gene }\end{array}$ & FJ641034 & 98 & 712 & 712 & Bacteria; Firmicutes; Bacillales; Bacillaceae; Bacillus \\
\hline A524 & tuft, 7 & HМ032210 & Paracoccus sp. jx9 $16 \mathrm{~S}$ ribosomal RNA gene & FJ539115 & 100 & 647 & 647 & $\begin{array}{l}\text { Bacteria; Proteobacteria; Alphaproteobacteria; } \\
\text { Rhodobacterales; Rhodobacteraceae; Paracoccus }\end{array}$ \\
\hline A525 & tuft, 7 & HM032209 & $\begin{array}{l}\text { Rheinheimera aquimaris strain SW-369 } 16 \mathrm{~S} \text { ribosomal } \\
\text { RNA gene }\end{array}$ & EF076758 & 99 & 725 & 727 & $\begin{array}{l}\text { Bacteria; Proteobacteria; Gammaproteobacteria; } \\
\text { Chromatiales;Chromatiaceae; Rheinheimera }\end{array}$ \\
\hline A543 & tuft, 7 & HM032192 & Uncultured Vibrio sp. partial $16 \mathrm{~S}$ rRNA gene, clone HG136 & FM958469 & 99 & 713 & 713 & N/A \\
\hline A543 & tuft, 7 & HM032192 & Vibrio sp. S3860 $16 \mathrm{~S}$ ribosomal RNA gene & FJ457568 & 99 & 713 & 713 & $\begin{array}{l}\text { Bacteria; Proteobacteria; Gammaproteobacteria; } \\
\text { Vibrionales;Vibrionacea; Vibrio }\end{array}$ \\
\hline A544 & tuft, 7 & HM032191 & Vibrio sp. C22-B $16 \mathrm{~S}$ ribosomal RNA gene & EU563342 & 100 & 725 & 725 & $\begin{array}{l}\text { Bacteria; Proteobacteria; Gammaproteobacteria; } \\
\text { Vibrionales;Vibrionaceae; Vibrio }\end{array}$ \\
\hline A459 & tuft, 8 & HM032244 & Pseudoalteromonas sp. S4491 $16 \mathrm{~S}$ ribosomal RNA gene & FJ457244 & 99 & 722 & 722 & $\begin{array}{l}\text { Bacteria; Proteobacteria; Gammaproteobacteria; Alteromonadales; } \\
\text { Pseudoalteromonadaceae; Pseudoalteromonas }\end{array}$ \\
\hline A494 & tuft, 8 & HМ032240 & Paracoccus sp. jx9 $16 \mathrm{~S}$ ribosomal RNA gene & FJ539115 & 99 & 716 & 716 & $\begin{array}{l}\text { Bacteria; Proteobacteria; Alphaproteobacteria; } \\
\text { Rhodobacterales; Rhodobacteraceae; Paracoccus }\end{array}$ \\
\hline A495 & tuft, 8 & НМОз2239 & $\begin{array}{l}\text { Acinetobacter venetianus partial } 16 \mathrm{~S} \text { rRNA gene, strain } \\
\text { ACl555 }\end{array}$ & AM909651 & 100 & 671 & 679 & $\begin{array}{l}\text { Bacteria; Proteobacteria; Gammaproteobacteria; Pseudomonadales } \\
\text { Moraxellaceae; Acinetobacter }\end{array}$ \\
\hline
\end{tabular}


Supplemental Table 2. Nearest GenBank neighbors of cultivars isolated at WHOI from frozen Trichodesmium colonies collected at BATS.

\begin{tabular}{|c|c|c|c|c|c|c|c|c|c|}
\hline Isolate ID & $\begin{array}{l}\text { Source } \\
\text { colony }\end{array}$ & $\begin{array}{l}\text { Isolation } \\
\text { method }\end{array}$ & Accession no. & Sequence ID of nearest BLAST match & \begin{tabular}{|c|}
$\begin{array}{c}\text { Accession no. } \\
\text { (BLAST } \\
\text { match) }\end{array}$ \\
\end{tabular} & PSI & $\begin{array}{c}\text { Number of } \\
\text { bases } \\
\text { compared }\end{array}$ & $\begin{array}{l}\text { Bit } \\
\text { score }\end{array}$ & Lineage \\
\hline A054 & Frozen filter & $\begin{array}{l}\text { Method 1, } \\
\text { SWT }\end{array}$ & НМ0з2254 & Pimelobacter simplex strain S151 16S rRNA gene & AY509240 & 97 & 619 & 1061 & $\begin{array}{l}\text { Bacteria; Actinobacteria; Actinobacteridae; Actinomycetales; } \\
\text { Propionibacterineae; Nocardioidaceae; Pimelobacter }\end{array}$ \\
\hline A055 & Frozen filter & $\begin{array}{l}\text { Method } 1 \text {, } \\
\text { SWT }\end{array}$ & HM032255 & Gordonia sp. FWA92 16S rRNA gene & AY115594 & 99 & 696 & 1264 & $\begin{array}{l}\text { Bacteria; Actinobacteria; Actinobacteridae; Actinomycetales; } \\
\text { Corynebacterineae; Gordoniaceae; Gordonia }\end{array}$ \\
\hline A059 & Frozen filter & $\begin{array}{l}\text { Method } 1 \text {, } \\
\text { SWT }\end{array}$ & HM032257 & Pimelobacter simplex strain S151 16S rRNA gene & AY509240 & 99 & 643 & 1182 & $\begin{array}{l}\text { Bacteria; Actinobacteria; Actinobacteridae; Actinomycetales; } \\
\text { Propionibacterineae; Nocardioidacea; Pimelobacter }\end{array}$ \\
\hline A061 & Frozen filter & $\begin{array}{l}\text { Method } 1, \\
\text { SWT }\end{array}$ & HМ032258 & Rhodococcus sp. VS-8 $16 \mathrm{~S}$ rRNA gene & FJ497702 & 99 & 745 & 1352 & $\begin{array}{l}\text { Bacteria; Actinobacteria; Actinobacteridae; } \\
\text { Actinomyctales; Corynebacterineae; Nocardiaceae; Rhodococcus }\end{array}$ \\
\hline A062 & Frozen filter & $\begin{array}{l}\text { Method } 1 \text {, } \\
\text { SWT }\end{array}$ & НМОз2259 & Aeromicrobium sp. 1/4_C7/16_31 16S rRNA gene & EF540466 & 98 & 764 & 1354 & $\begin{array}{l}\text { Bacteria; Actinobacteria; Actinobacteridae; Actinomycetales; } \\
\text { Propionibacterineae; Nocardioidaceae; Aeromicrobium }\end{array}$ \\
\hline A063 & Frozen filter & $\begin{array}{l}\text { Method } 1, \\
\text { SWT }\end{array}$ & HМ032260 & Uncultured bacterium clone CE2-DCM-13 $16 \mathrm{~S}$ rRNA gene & GU061599 & 99 & 766 & 1402 & N/A \\
\hline A064 & Frozen filter & $\begin{array}{l}\text { Method } 1 \text {, } \\
\text { SWT }\end{array}$ & HM032261 & Gordonia sp. CNJ786 PL04 16S rRNA gene & DQ448772 & 97 & 634 & 1092 & $\begin{array}{l}\text { Bacteria; Actinobacteria; Actinobacteridae; Actinomycetales; } \\
\text { Corynebacterineae; Gordoniaceae; Gordonia }\end{array}$ \\
\hline A065 & Frozen filter & $\begin{array}{l}\text { Method } 1, \\
\text { SWT }\end{array}$ & HM032262 & Rhodococcus sp. VS-8 16 S rRNA gene & FJ497702 & 99 & 720 & 1301 & $\begin{array}{l}\text { Bacteria; Actinobacteria; Actinobacteridae; } \\
\text { Actinomycetales; Corynebacterineae; Nocardiaceae; Rhodococcus }\end{array}$ \\
\hline A066 & Frozen filter & $\begin{array}{l}\text { Method } 1, \\
\text { SWT }\end{array}$ & НМОз2263 & Rhodococcus sp. VS-8 $16 \mathrm{~S}$ rRNA gene & FJ497702 & 99 & 691 & 1264 & $\begin{array}{l}\text { Bacteria; Actinobacteria; Actinobacteridae; } \\
\text { Actinomycetales; Corynebacterineae; Nocardiaceae; Rhodococcus }\end{array}$ \\
\hline A067 & Frozen filter & $\begin{array}{l}\text { Method } 1, \\
\text { SWT }\end{array}$ & HM032264 & Paracoccus sp. MBIC 3024 gene for $16 \mathrm{~S}$ rRNA & AB008115 & 99 & 655 & 1199 & $\begin{array}{l}\text { Bacteria; Proteobacteria; Alphaproteobacteria; Rhodobacterales; } \\
\text { Rhodobacteraceae; Paracoccus }\end{array}$ \\
\hline A071 & Frozen filter & $\begin{array}{l}\text { Method } 1, \\
\text { SWT }\end{array}$ & HM032265 & Bacterium daSW.34 16S rRNA gene & EU935309 & 99 & 770 & 1387 & N/A \\
\hline A072 & Frozen filter & $\begin{array}{l}\text { Method } 1 \text {, } \\
\text { SWT }\end{array}$ & HМ032266 & Gordonia sp. FWA92 16S rRNA gene & AY115594 & 92 & 595 & 854 & $\begin{array}{l}\text { Bacteria; Actinobacteria; Actinobacteridae; Actinomycetales; } \\
\text { Corynebacterineae; Gordoniaceae; Gordonia }\end{array}$ \\
\hline A073 & Frozen filter & $\begin{array}{l}\text { Method } 1, \\
\text { SWT }\end{array}$ & HМ032267 & Gordonia sp. FWA92 16S rRNA gene & AY115594 & 92 & 595 & 843 & $\begin{array}{l}\text { Bacteria; Actinobacteria; Actinobacteridae; Actinomycetales; } \\
\text { Corynebacterineae; Gordoniaceae; Gordonia }\end{array}$ \\
\hline A075 & Frozen filter & $\begin{array}{l}\text { Method } 1 \text {, } \\
\text { SWT }\end{array}$ & HM032268 & Gordonia sp. FWA92 16S rRNA gene & AY115594 & 91 & 602 & 828 & $\begin{array}{l}\text { Bacteria; Actinobacteria; Actinobacteridae; Actinomycetales; } \\
\text { Corynebacterineae; Gordoniaceae; Gordonia }\end{array}$ \\
\hline A078 & Frozen filter & $\begin{array}{l}\text { Method } 1 \text {, } \\
\text { SWT }\end{array}$ & HM032269 & Pimelobacter simplex strain S151 16S rRNA gene & AY509240 & 98 & 690 & 1208 & $\begin{array}{l}\text { Bacteria; Actinobacteria; Actinobacteridae; Actinomycetales; } \\
\text { Propionibacterineae; Nocardioidaceae; Pimelobacter }\end{array}$ \\
\hline A080 & Frozen filter & $\begin{array}{l}\text { Method } 1, \\
\text { SWT }\end{array}$ & HМ032270 & Aeromicrobium sp. 1/4_C7/16_31 16S rRNA gene & EF540466 & 98 & 743 & 1321 & $\begin{array}{l}\text { Bacteria; Actinobacteria; Actinobacteridae; Actinomycetales; } \\
\text { Propionibacterineae; Nocardioidaceae; Aeromicrobium }\end{array}$ \\
\hline A081 & Frozen filter & $\begin{array}{l}\text { Method } 1, \\
\text { SWT }\end{array}$ & HM032271 & Pimelobacter simplex strain S151 16S rRNA gene & AY509240 & 99 & 763 & 1402 & $\begin{array}{l}\text { Bacteria; Actinobacteria; Actinobacteridae; Actinomycetales; } \\
\text { Propionibacterineae; Nocardioidaceae; Pimelobacter }\end{array}$ \\
\hline A082 & Frozen filter & $\begin{array}{l}\text { Method } 1 \text {, } \\
\text { SWT }\end{array}$ & HM032272 & Pimelobacter simplex strain S151 16S rRNA gene & AY509240 & 97 & 593 & 1002 & $\begin{array}{l}\text { Bacteria; Actinobacteria; Actinobacteridae; Actinomycetales; } \\
\text { Propionibacterineae; Nocardioidaceae; Pimmlobacter }\end{array}$ \\
\hline A083 & Frozen filter & $\begin{array}{l}\text { Method } 1, \\
\text { SWT }\end{array}$ & НМ0з2273 & Aeromicrobium sp. 1/4_C7/16_31 16S rRNA gene & EF540466 & 99 & 772 & 1387 & $\begin{array}{l}\text { Bacteria; Actinobacteria; Actinobacteridae; Actinomycetales; } \\
\text { Propionibacterineae; Nocardioidaceae; Aeromicrobium }\end{array}$ \\
\hline A084 & Frozen filter & $\begin{array}{l}\text { Method } 1, \\
\text { SWT }\end{array}$ & HМ032274 & Agromyces sp. Xb-3 $16 \mathrm{~S}$ rRNA gene & DQ311007 & 99 & 761 & 1393 & $\begin{array}{l}\text { Bacteria; Actinobacteria; Actinobacteridae; Actinomycetales; } \\
\text { Micrococcineae; Microbacteriaceae; Agromyces }\end{array}$ \\
\hline A085 & Frozen filter & $\begin{array}{l}\text { Method } 1, \\
\text { SWT }\end{array}$ & HM032275 & Pimelobacter simplex strain S151 16S rRNA gene & AY509240 & 99 & 712 & 1304 & $\begin{array}{l}\text { Bacteria; Actinobacteria; Actinobacteridae; Actinomycetales; } \\
\text { Propionibacterineae; Nocardioidaceae; Pimmelobacter }\end{array}$ \\
\hline A088 & Frozen filter & $\begin{array}{l}\text { Method } 1 \text {, } \\
\text { SWT }\end{array}$ & НМОз2276 & Gordonia sp. FWA92 $16 \mathrm{~S}$ rRNA gene & AY115594 & 99 & 693 & 1258 & $\begin{array}{l}\text { Bacteria; Actinobacteria; Actinobacteridae; Actinomycetales; } \\
\text { Corynebacterineae; Gordoniaceae; Gordonia }\end{array}$ \\
\hline A089 & Frozen filter & $\begin{array}{l}\text { Method } 1, \\
\text { SWT }\end{array}$ & HМ032277 & Pimelobacter simplex strain S151 16S rRNA gene & AY509240 & 99 & 753 & 1363 & $\begin{array}{l}\text { Bacteria; Actinobacteria; Actinobacteridae; Actinomycetales; } \\
\text { Propionibacterineae; Nocardioidaceae; Pimelobacter }\end{array}$ \\
\hline
\end{tabular}




\begin{tabular}{|c|c|c|c|c|c|c|c|c|c|}
\hline Isolate ID & $\begin{array}{l}\text { Source } \\
\text { colony }\end{array}$ & $\begin{array}{l}\text { Isolation } \\
\text { method }\end{array}$ & Accession no. & Sequence ID of nearest BLAST match & $\begin{array}{c}\text { Accession no. } \\
\text { (BLAST } \\
\text { match) }\end{array}$ & PSI & $\begin{array}{c}\begin{array}{c}\text { Number of } \\
\text { bases } \\
\text { compared }\end{array} \\
\end{array}$ & $\begin{array}{l}\text { Bit } \\
\text { score }\end{array}$ & Lineage \\
\hline A090 & Frozen filter & $\begin{array}{l}\text { Method 1, } \\
\text { SWT }\end{array}$ & HM032278 & Aeromicrobium sp. 1/4_C7/16_31 16S rRNA gene & EF540466 & 98 & 723 & 1284 & $\begin{array}{l}\text { Bacteria; Actinobacteria; Actinobacteridae; Actinomycetales; } \\
\text { Propionibacterineae; Nocardioidaceae; Aeromicrobium }\end{array}$ \\
\hline A095 & Frozen filter & $\begin{array}{l}\text { Method } 1, \\
\text { SWT }\end{array}$ & HМ032279 & Gordonia sp. FWA92 $16 \mathrm{~S}$ rRNA gene & AY115594 & 89 & 577 & 743 & $\begin{array}{l}\text { Bacteria; Actinobacteria; Actinobacteridae; Actinomycetales; } \\
\text { Corynebacterineae; Gordoniaceae; Gordonia }\end{array}$ \\
\hline A096 & Frozen filter & $\begin{array}{l}\text { Method } 1, \\
\text { SWT }\end{array}$ & нм032280 & Rhodococcus sp. VS-8 16 S rRNA gene & FJ497702 & 99 & 749 & 1365 & $\begin{array}{l}\text { Bacteria; Actinobacteria; Actinobacteridae; Actinomycetales; } \\
\text { Corynebacterineae; Nocardiaceae; Rhodococcus. }\end{array}$ \\
\hline A097 & Frozen filter & $\begin{array}{l}\text { Method } 1, \\
\text { SWT }\end{array}$ & HM032281 & Gordonia sp. CNJ786 PL04 16S rRNA gene & DQ448772 & 99 & 743 & 1332 & $\begin{array}{l}\text { Bacteria; Actinobacteria; Actinobacteridae; Actinomycetales; } \\
\text { Corynebacterineae; Gordoniaceae; Gordonia }\end{array}$ \\
\hline A100 & Frozen filter & $\begin{array}{l}\text { Method } 1, \\
\text { SWT }\end{array}$ & HМ032282 & Paracoccus sp. MBIC 3024 gene for $16 \mathrm{~S}$ rRNA & AB008115 & 99 & 669 & 1225 & $\begin{array}{l}\text { Bacteria; Proteobacteria; Alphaproteobacteria; } \\
\text { Rhodobacterales; Rhodobacteraceae; Paracoccus }\end{array}$ \\
\hline A102 & Frozen filter & $\begin{array}{l}\text { Method } 1, \\
\text { SWT }\end{array}$ & НМ032283 & Pimelobacter simplex strain S151 16S rRNA gene & AY509240 & 97 & 600 & 1013 & $\begin{array}{l}\text { Bacteria; Actinobacteria; Actinobacteridae; Actinomycetales; } \\
\text { Propionibacterineae; Nocardioidaceae; Pimelobacter }\end{array}$ \\
\hline A109 & Frozen filter & $\begin{array}{l}\text { Method } 1, \\
\text { SWT }\end{array}$ & HМ032284 & Pimelobacter simplex strain S151 16S rRNA gene & AY509240 & 98 & 681 & 1190 & $\begin{array}{l}\text { Bacteria; Actinobacteria; Actinobacteridae; Actinomycetales; } \\
\text { Propionibacterineae; Nocardioidaceae; Pimelobacter }\end{array}$ \\
\hline A110 & Frozen filter & $\begin{array}{l}\text { Method } 1, \\
\text { SWT }\end{array}$ & HM032285 & Paracoccus sp. MBIC3024 gene for $16 \mathrm{~S}$ rRNA & AB008115 & 98 & 734 & 1310 & $\begin{array}{l}\text { Bacteria; Proteobacteria; Alphaproteobacteria; } \\
\text { Rhodobacterales; Rhodobacteraceae; Paracoccus }\end{array}$ \\
\hline A056 & Frozen filter & $\begin{array}{l}\text { Method } 1 \text {, } \\
\text { VSS }\end{array}$ & HM032256 & Gordonia sp. FWA92 16S RNA gene & AY115594 & 89 & 548 & 704 & $\begin{array}{l}\text { Bacteria; Actinobacteria; Actinobacteridae; Actinomycetales; } \\
\text { Corynebacterineae; Gordoniaceae; Gordonia }\end{array}$ \\
\hline A036 & Frozen filter & $\begin{array}{l}\text { Method } 1, \\
\text { Vss }\end{array}$ & HM032248 & Gordonia sp. FWA92 $16 \mathrm{~S}$ rRNA gene & AY 115594 & 98 & 693 & 1221 & $\begin{array}{l}\text { Bacteria; Actinobacteria; Actinobacteridae; Actinomycetales; } \\
\text { Corynebacterineae; Gordoniaceae; Gordonia }\end{array}$ \\
\hline A037 & Frozen filter & $\begin{array}{l}\text { Method } 1 \text {, } \\
\text { VSS }\end{array}$ & HM032249 & Rhodococcus sp. VS-8 16S rRNA gene & FJ497702 & 96 & 728 & 1208 & $\begin{array}{l}\text { Bacteria; Actinobacteria; Actinobacteridae; } \\
\text { Actinomycetales; Corynebacterineae; Nocardiaceae; Rhodococcus }\end{array}$ \\
\hline A039 & Frozen filter & $\begin{array}{l}\text { Method } 1, \\
\text { VSS }\end{array}$ & HM032250 & Rhodococcus sp. Vs-8 $16 \mathrm{~S}$ rRNA gene & FJ497702 & 99 & 749 & 1365 & $\begin{array}{l}\text { Bacteria; Actinobacteria; Actinobacteridae; } \\
\text { Actinomy cetales; Corynebacterineae; Nocardiaceae; Rhodococcus }\end{array}$ \\
\hline A041 & Frozen filter & $\begin{array}{l}\text { Method } 1, \\
\text { VsS }\end{array}$ & HМ032251 & Rhodococcus sp. VS-8 $16 \mathrm{~S}$ rRNA gene & FJ497702 & 99 & 773 & 1410 & $\begin{array}{l}\text { Bacteria; Actinobacteria; Actinobacteridae; } \\
\text { Actinomycetales; Corynebacterineae; Nocardiaceae; Rhodococcus }\end{array}$ \\
\hline A049 & Frozen filter & $\begin{array}{l}\text { Method } 1 \text {, } \\
\text { VSS }\end{array}$ & HМ032252 & Rhodococcus sp. VS-8 16S rRNA gene & FJ497702 & 99 & 773 & 1415 & $\begin{array}{l}\text { Bacteria; Actinobacteria; Actinobacteridae; } \\
\text { Actinomycetales; Corynebacterineae; Nocardiaceae; Rhodococcus }\end{array}$ \\
\hline A051 & Frozen filter & $\begin{array}{l}\text { Method } 1 \text {, } \\
\text { VSS }\end{array}$ & HM032253 & Pimelobacter simplex strain S151 16S rRNA gene & AY509240 & 99 & 762 & 1373 & $\begin{array}{l}\text { Bacteria; Actinobacteria; Actinobacteridae; Actinomycetales; } \\
\text { Propionibacterineae; Nocardioidaceae; Pimelobacter }\end{array}$ \\
\hline A111 & Frozen filter & $\begin{array}{l}\text { Method } 3, \\
\text { VSS }\end{array}$ & HM032286 & Rhodococcus sp. VS-8 16S rRNA gene & FJ497702 & 99 & 746 & 1360 & $\begin{array}{l}\text { Bacteria; Actinobacteria; Actinobacteridae; Actinomycetales; } \\
\text { Corynebacterineae; Nocardiaceae; Rhodococcus. }\end{array}$ \\
\hline A113 & Frozen filter & $\begin{array}{l}\text { Method } 3 \text {, } \\
\text { VSS }\end{array}$ & HM032287 & Rhodococcus sp. VS-8 $16 \mathrm{~S}$ rRNA gene & FJ497702 & 99 & 741 & 1356 & $\begin{array}{l}\text { Bacteria; Actinobacteria; Actinobacteridae; Actinomycetales; } \\
\text { Corynebacterineae; Nocardiaceae; Rhodococcus. }\end{array}$ \\
\hline A114 & Frozen filter & $\begin{array}{l}\text { Method } 3 \text {, } \\
\text { SWT }\end{array}$ & HM032288 & Agromyces sp. MJ21 $16 \mathrm{~S}$ rRNA gene & GQ241325 & 98 & 649 & 1158 & $\begin{array}{l}\text { Bacteria; Actinobacteria; Actinobacteridae; Actinomycetales; } \\
\text { Micrococcineae; Microbacteriaceae; Agromyces }\end{array}$ \\
\hline A115 & Frozen filter & $\begin{array}{l}\text { Method } 3, \\
\text { SWT }\end{array}$ & HM032289 & Agromyces sp. MJ21 16S rRNA gene & GQ241325 & 97 & 648 & 1112 & $\begin{array}{l}\text { Bacteria; Actinobacteria; Actinobacteridae; Actinomycetales; } \\
\text { Micrococcineae; Microbacteriaceae; Agromyces }\end{array}$ \\
\hline A116 & Frozen filter & $\begin{array}{l}\text { Method } 3 \text {, } \\
\text { SWT }\end{array}$ & HM032290 & Agromyces sp. MJ21 16S rRNA gene & GQ241325 & 97 & 697 & 1208 & $\begin{array}{l}\text { Bacteria; Actinobacteria; Actinobacteridae; Actinomycetales; } \\
\text { Micrococcineae; Microbacteriaceae; Agromyces }\end{array}$ \\
\hline A117 & Frozen filter & $\begin{array}{l}\text { Method } 3 \text {, } \\
\text { SWT }\end{array}$ & HM032291 & Agromyces sp. MJ21 16S rRNA gene & GQ241325 & 96 & 649 & 1086 & $\begin{array}{l}\text { Bacteria; Actinobacteria; Actinobacteridae; Actinomycetales; } \\
\text { Micrococcineae; Microbacteriaceae; Agromyces }\end{array}$ \\
\hline A118 & Frozen filter & $\begin{array}{l}\text { Method } 3 \text {, } \\
\text { SWT }\end{array}$ & HM032292 & Agromyces sp. MJ21 16S rRNA gene & GQ241325 & 95 & 520 & 828 & $\begin{array}{l}\text { Bacteria; Actinobacteria; Actinobacteridae; Actinomycetales; } \\
\text { Micrococcineae; Microbacteriaceae; Agromyces }\end{array}$ \\
\hline A127 & Frozen filter & $\begin{array}{l}\text { Method } 4, \\
\text { SWT }\end{array}$ & HM032293 & Bacterium enrichment culture clone NCAAH $30 A 10$ & GQ221076 & 98 & 769 & 1371 & 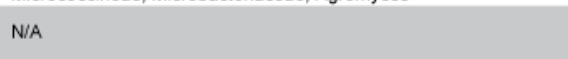 \\
\hline A127 & Frozen filter & $\begin{array}{l}\text { Method } 4 \text {, } \\
\text { SWT }\end{array}$ & HМ032293 & Vitellibacter sp. D7-13 partial $16 \mathrm{~S}$ rRNA gene, isolate $D 7-1: A$ & :AM403205 & 98 & 766 & 1347 & $\begin{array}{l}\text { Bacteria; Bacteroidetes; Flavobacteria; Flavobacteriales; } \\
\text { Flavobacteriaceae; Vitellibacter }\end{array}$ \\
\hline A128 & Frozen filter & $\begin{array}{l}\text { Method } 4, \\
\text { SWT }\end{array}$ & HМ032294 & Agromyces sp. MJ21 16S rRNA gene & GQ241325 & 96 & 621 & 1016 & $\begin{array}{l}\text { Bacteria; Actinobacteria; Actinobacteridae; Actinomycetales; } \\
\text { Micrococcineae; Microbacteriaceae; Agromyces }\end{array}$ \\
\hline A132 & Frozen filter & $\begin{array}{l}\text { Method } 4, \\
\text { SWT }\end{array}$ & HM032295 & Agromyces mediolanus strain c18 $16 \mathrm{~S}$ ribosomal RNA g & 4FJ950540 & 100 & 730 & 1349 & $\begin{array}{l}\text { Bacteria; Actinobacteria; Actinobacteridae; Actinomycetales; } \\
\text { Micrococcineae; Microbataceriaceae; Agromyces }\end{array}$ \\
\hline
\end{tabular}




\begin{tabular}{|c|c|c|c|c|c|c|c|c|c|}
\hline Isolate ID & $\begin{array}{l}\text { Source } \\
\text { colony }\end{array}$ & $\begin{array}{l}\text { Isolation } \\
\text { method }\end{array}$ & Accession no. & Sequence ID of nearest BLAST match & $\begin{array}{l}\text { Accession no. } \\
\text { (BLAST } \\
\text { match) }\end{array}$ & PSI & $\begin{array}{c}\text { Number of } \\
\text { bases } \\
\text { compared }\end{array}$ & $\begin{array}{l}\text { Bit } \\
\text { score }\end{array}$ & Lineage \\
\hline A137 & Frozen filter & $\begin{array}{l}\text { Method } 4 \text {, } \\
\text { Methylophaga }\end{array}$ & HM032296 & Gordonia sp. FWA92 16S rRNA gene & AY115594 & 91 & 549 & 758 & $\begin{array}{l}\text { Bacteria; Actinobacteria; Actinobacteridae; Actinomycetales; } \\
\text { Corynebacterineae; Gordoniaceae; Gordonia }\end{array}$ \\
\hline A159 & Frozen filter & $\begin{array}{l}\text { Method } 3 \\
\text { VSS }\end{array}$ & HM032297 & Rhodococcus sp. VS-8 $16 \mathrm{~S}$ rRNA gene & FJ497702 & 99 & 749 & 1360 & $\begin{array}{l}\text { Bacteria; Actinobacteria; Actinobacteridae; Actinomycetales; } \\
\text { Corynebacterineae; Nocardiaceae; Rhodococcus. }\end{array}$ \\
\hline A160 & Frozen filter & $\begin{array}{l}\text { Method 3, } \\
\text { SWT }\end{array}$ & HM032298 & Bacterium enrichment culture clone NCAAH 30A10 & GQ221076 & 99 & 769 & 1384 & N/A \\
\hline A160 & Frozen filter & $\begin{array}{l}\text { Method } 3, \\
\text { SWT }\end{array}$ & нМоз2298 & Vitellibacter sp. D7-13 partial $16 \mathrm{~S}$ rRNA gene, isolate D7-1: & :AM403205 & 98 & 769 & 1365 & $\begin{array}{l}\text { Bacteria; Bacteroidetes; Flavobacteria; Flavobacteriales; } \\
\text { Flavobacteriaceae; Vitellibacter }\end{array}$ \\
\hline A161 & Frozen filter & $\begin{array}{l}\text { Method 3, } \\
\text { SWT }\end{array}$ & НМ032299 & Bacterium enrichment culture clone NCAAH 30A10 & GQ221076 & 94 & 592 & 900 & N/A \\
\hline A161 & Frozen filter & $\begin{array}{l}\text { Method 3, } \\
\text { SWT }\end{array}$ & НM032299 & Vitellibacter sp. D7-13 partial $16 \mathrm{~S}$ rRNA gene, isolate D7-1: & :AM403205 & 93 & 592 & 876 & $\begin{array}{l}\text { Bacteria; Bacteroidetes; Flavobacteria; Flavobacteriales; } \\
\text { Flavobacteriaceae; Vitellibacter }\end{array}$ \\
\hline A162 & Frozen filter & $\begin{array}{l}\text { Method 3, } \\
\text { SWT }\end{array}$ & НМ032300 & Agromyces sp. MJ21 16S rRNA gene & GQ241325 & 99 & 701 & 1266 & $\begin{array}{l}\text { Bacteria; Actinobacteria; Actinobacteridae; Actinomycetales; } \\
\text { Micrococcineae; Microbacteriaceae; Agromyces }\end{array}$ \\
\hline A163 & Frozen filter & $\begin{array}{l}\text { Method 3, } \\
\text { SWT }\end{array}$ & НМ032301 & Bacterium enrichment culture clone NCAAH $30 \mathrm{~A} 10$ & GQ221076 & 99 & 768 & 1397 & N/A \\
\hline A163 & Frozen filter & $\begin{array}{l}\text { Method 3, } \\
\text { SWT }\end{array}$ & HМ032301 & Vitellibacter sp. D7-13 partial $16 \mathrm{~S}$ rRNA gene, isolate D7-1: & :AM403205 & 99 & 768 & 1378 & $\begin{array}{l}\text { Bacteria; Bacteroidetes; Flavobacteria; Flavobacteriales; } \\
\text { Flavobacteriaceae; Vitellibacter }\end{array}$ \\
\hline A164 & Frozen filter & $\begin{array}{l}\text { Method 3, } \\
\text { SWT }\end{array}$ & HM032302 & Agromyces sp. MJ21 16S rRNA gene & GQ241325 & 99 & 684 & 1229 & $\begin{array}{l}\text { Bacteria; Actinobacteria; Actinobacteridae; Actinomycetales; } \\
\text { Micrococcineae; Microbacteriaceae; Agromyces }\end{array}$ \\
\hline A165 & Frozen filter & $\begin{array}{l}\text { Method 3, } \\
\text { SWT }\end{array}$ & HМ032303 & Bacterium enrichment culture clone NCAAH $30 \mathrm{~A} 10$ & GQ221076 & 99 & 772 & 1404 & 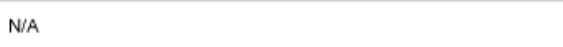 \\
\hline A165 & Frozen filter & $\begin{array}{l}\text { Method 3, } \\
\text { SWT }\end{array}$ & HМ032303 & Vitellibacter sp. D7-13 partial $16 \mathrm{~S}$ rRNA gene, isolate D7-1: & :AM403205 & 99 & 769 & 1380 & $\begin{array}{l}\text { Bacteria; Bacteroidetes; Flavobacteria; Flavobacteriales; } \\
\text { Flavobacteriaceae; Vitellibacter }\end{array}$ \\
\hline A168 & Frozen filter & $\begin{array}{l}\text { Method 1, } \\
\text { SWT }\end{array}$ & HМ032304 & Uncultured bacterium clone CE2-DCM-93 16S rRNA gene & GU061604 & 99 & 644 & 1158 & N/A \\
\hline A168 & Frozen filter & $\begin{array}{l}\text { Method 1, } \\
\text { SWT }\end{array}$ & HМ032304 & Bacterium daSW.34 16S rRNA gene & EU935309 & 99 & 644 & 1158 & N/A \\
\hline A169 & Frozen filter & $\begin{array}{l}\text { Method 1, } \\
\text { SWT }\end{array}$ & HM032305 & Pimelobacter simplex strain S151 16S rRNA gene & AY509240 & 97 & 668 & 1129 & $\begin{array}{l}\text { Bacteria; Actinobacteria; Actinobacteridae; Actinomycetales; } \\
\text { Propionibacterineae; Nocardioidaceae; Pimelobacter }\end{array}$ \\
\hline A170 & Frozen filter & $\begin{array}{l}\text { Method 1, } \\
\text { SWT }\end{array}$ & HМ032306 & Uncultured bacterium isolate M6 $16 \mathrm{~S}$ rRNA gene & EF455588 & 99 & 687 & 1258 & N/A \\
\hline A171 & Frozen filter & $\begin{array}{l}\text { Method 1, } \\
\text { SWT }\end{array}$ & нм032307 & Aeromicrobium sp. 1/4_C7/16_31 16S rRNA gene & EF540466 & 99 & 772 & 1399 & $\begin{array}{l}\text { Bacteria; Actinobacteria; Actinobacteridae; Actinomycetales; } \\
\text { Propionibacterineae; Nocardioidaceae; Aeromicrobium }\end{array}$ \\
\hline A172 & Frozen filter & $\begin{array}{l}\text { Method 1, } \\
\text { SWT }\end{array}$ & НМ0з2308 & Uncultured organism clone ctg_CGOF202 16S rRNA gene & DQ395725 & 94 & 484 & 745 & N/A \\
\hline A172 & Frozen filter & $\begin{array}{l}\text { Method 1, } \\
\text { SWT }\end{array}$ & HМ032308 & Novosphingobium tardaugens & AB070237 & 94 & 483 & 734 & $\begin{array}{l}\text { Bacteria; Proteobacteria; Alphaproteobacteria; Sphingomonadales; } \\
\text { Sphingomonadaceae; Novosphingobium }\end{array}$ \\
\hline A174 & Frozen filter & $\begin{array}{l}\text { Method 1, } \\
\text { SWT }\end{array}$ & HM032309 & Pimelobacter simplex strain S151 16S rRNA gene & AY509240 & 99 & 723 & 1323 & $\begin{array}{l}\text { Bacteria; Actinobacteria; Actinobacteridae; Actinomycetales; } \\
\text { Propionibacterineae; Nocardioidaceae; Pimelobacter }\end{array}$ \\
\hline A181 & Frozen filter & $\begin{array}{l}\text { Method 3, } \\
\text { SWT }\end{array}$ & HM032310 & Pimelobacter simplex strain S151 16S rRNA gene & AY509240 & 99 & 756 & 1384 & $\begin{array}{l}\text { Bacteria; Actinobacteria; Actinobacteridae; Actinomycetales; } \\
\text { Propionibacterineae; Nocardioidaceae; Pimelobacter }\end{array}$ \\
\hline
\end{tabular}




\section{REFERENCES}

Altschul, S., Madden, T., Schaffer, A., Zhang, J., Zhang, Z., Miller, W., \& Lipman, D. (1997) Gapped BLAST and PSI-BLAST: a new generation of protein database search programs 10.1093/nar/25.17.3389. Nucl Acids Res 25: 3389-3402.

Blosser-Middleton, R. S., \& Gray, K. M. (2001) Multiple N-acyl homoserine lactone signals of Rhizobium leguminosarum are synthesized in a distinct temporal pattern. $J$ Bacteriol 183: 6771-6777.

Brelles-Marino, G., \& Bedmar, E. J. (2001) Detection, purification and characterisation of quorum-sensing signal molecules in plant-associated bacteria. $J$ Biotechnol 91: 197-209.

Bruns, A., Cypionka, H., \& Overmann, J. (2002) Cyclic AMP and acyl homoserine lactones increase the cultivation efficiency of heterotrophic bacteria from the Central Baltic Sea. Appl Environ Microbiol 68: 3978-3987.

Buchan, A., Gonzalez, J. M., \& Moran, M. A. (2005) Overview of the marine Roseobacter lineage. Appl Environ Microbiol 71: 5665-5677.

Burton, E. O., Read, H. W., Pellitteri, M. C., \& Hickey, W. J. (2005) Identification of acyl-homoserine lactone signal molecules produced by Nitrosomonas europaea strain Schmidt. Appl Environ Microbiol 71: 4906-4909.

Case, R. J., Labbate, M., \& Kjelleberg, S. (2008) AHL-driven quorum-sensing circuits: their frequency and function among the Proteobacteria. ISME J 2: 345.

Cataldi, T. R. I., Bianco, G., \& Abate, S. (2008) Profiling of N-acyl-homoserine lactones by liquid chromatography coupled with electrospray ionization and a hybrid quadrupole linear ion-trap and Fourier-transform ion-cyclotron-resonance mass spectrometry (LC-ESI-LTQ-FTICR-MS). J Mass Spectrom 43: 82-96.

Charlton, T. S., de Nys, R., Netting, A., Kumar, N., Hentzer, M., Givskov, M., \& Kjelleberg, S. (2000) A novel and sensitive method for the quantification of N-3oxoacyl homoserine lactones using gas chromatography-mass spectrometry: application to a model bacterial biofilm. Environ Microbiol 2: 530-541.

Chilton, M., Currier, T. C., Farrand, S. K., Bendich, A. J., Gordon, M. P., \& Nester, E. W. (1974) Agrobacterium tumefaciens DNA and PS8 bacteriophage DNA not detected in crown gall tumors. PNAS 71: 3672-3676. 
Cole, J. R., Chai, B., Marsh, T. L., Farris, R. J., Wang, Q., Kulam, S. A. et al. (2003) The Ribosomal Database Project (RDP-II): previewing a new autoaligner that allows regular updates and the new prokaryotic taxonomy. Nucl Acids Res 31: 442-443.

Davies, D. G., Parsek, M. R., Pearson, J. P., Iglewski, B. H., Costerton, J. W., \& Greenberg, E. P. (1998) The involvement of cell-to-cell signals in the development of a bacterial biofilm. Science 280: 295-298.

Decho, A. W., Visscher, P. T., Tomohiro, J. F., He, K. L., Przekop, K. M., Norman, R. S., \& Reid, R. P. (2009) Autoinducers extracted from microbial mats reveal a surprising diversity of $N$-acylhomoserine lactones (AHLs) and abundance changes that may relate to diel pH. Environ Microbiol 11: 409-420.

Decho, A. W. (2000) Microbial biofilms in intertidal systems: an overview. Cont Shelf Res 20: 1257-1273.

D'Onofrio, A., Crawford, J. M., Stewart, E. J., Witt, K., Gavrish, E., Epstein, S. et al. (2010) Siderophores from Neighboring Organisms Promote the Growth of Uncultured Bacteria. Chem Biol 17: 254-264.

Dulla, G. F. J., \& Lindow, S. E. (2009) Acyl-homoserine lactone-mediated cross talk among epiphytic bacteria modulates behavior of Pseudomonas syringae on leaves. ISME J 1-10.

Eberhard, A., Burlingame, A., Eberhard, C., Kenyon, G., Nealson, K., \& Oppenheimer, N. (1981) Structural identification of autoinducer of Photobacterium fischeri luciferase. Biochem 20: 2444-2449.

Farrand, S. K., Qin, Y., \& Oger, P. (2002) Quorum-sensing system of Agrobacterium plasmids: Analysis and utility. Method Enzymol 358: 452-484.

Fekete, A., Frommberger, M., Rothballer, M., Li, X., Englmann, M., Fekete, J. et al. (2007) Identification of bacterial N-acylhomoserine lactones (AHLs) with a combination of ultra-performance liquid chromatography (UPLC), ultra-highresolution mass spectrometry, and in-situ biosensors. Anal Bioanal Chem 387: 455467.

Fuqua, C., Winans, S. C., \& Greenberg, E. P. (1996) Census and concensus in bacterial ecosystems: The LuxR-LuxI Family of quorum-sensing transcriptional regulators. Annual Review of Microbiol 50: 727-751.

Garcia-Aljaro, C., Eberl, L., Riedel, K., \& Blanch, A. (2008) Detection of quorumsensing-related molecules in Vibrio scophthalmi. BMC Microbiology 8: 138. 
Giovannoni, S. J., \& Rappe, M. S. (2000) Evolution, diversity, and molecular ecology of marine prokaryotes. In Microbial ecology of the oceans. D. L. Kirchman (ed). New York, Wiley-Liss,

Gram, L., Grossart, H., Schlingloff, A., \& Kiorboe, T. (2002) Possible quorum sensing in marine snow bacteria: Production of acylated homoserine lactones by Roseobacter strains isolated from marine snow. Appl Environ Microb 68: 4111-4116.

Hmelo, L. (2010) Biogeochemical implications of biofilms and bacterial quorum sensing associated with living and detrital particles in the ocean, Ph.D. thesis.

Hmelo, L., \& Van Mooy, B. A. S. (2009) Kinetic constraints on acylated homoserine lactone-based quorum sensing in marine environments. Aquat Microb Ecol 54: 127133.

Holden, M. T. G. (1999) Quorum-sensing cross talk: isolation and chemical characterization of cyclic dipeptides from Pseudomonas aeruginosa and other gramnegative bacteria. Mol Microbiol 33: 1254.

Kaplan, H. B., \& Greenberg, E. P. (1985) Diffusion of autoinducer is involved in regulation of the Vibrio fischeri luminescence system. J Bacteriol 163: 1210-1214.

Ludwig, W. (2004) ARB: a software environment for sequence data. Nucleic Acids Research 32: 1363-1371.

Marketon, M. M., Gronquist, M. R., Eberhard, A., \& Gonzalez, J. E. (2002) Characterization of the Sinorhizobium meliloti $\sin \mathrm{R} / \sin$ I locus and the production of novel N-acyl homoserine lactones. J Bacteriol 184: 5686.

Marmur, J. (1961) A procedure for the isolation of deoxyribonucleic acid from microorganisms. J Mol Biol 3: 208-218.

Martens, T., Gram, L., Grossart, H. P., Kessler, D., Muller, R., Simon, M. et al. (2007) Bacteria of the Roseobacter clade show potential for secondary metabolite production. Microb Ecol 54: 31-42.

Milton, D. L. (2006) Quorum sensing in vibrios: complexity for diversification. Int J Med Microbiol 296: 61-71.

Morin, D., Grasland, B., Vallee-Rehel, K., Dufau, C., \& Haras, D. (2003) On-line highperformance liquid chromatography-mass spectrometric detection and quantification of $\mathrm{N}$-acylhomoserine lactones, quorum sensing signal molecules, in the presence of biological matrices. J Chromatogr A 1002: 79-92. 
Nealson, K. H., Platt, T., \& Hastings, J. W. (1970) Cellular control of the synthesis and activity of the bacterial luminescent system. J Bacteriol 104: 313-322.

Nealson, K. H., \& Hastings, J. W. (2006) Quorum sensing on a global scale: Massive numbers of bioluminescent bacteria make Milky Seas. Appl Environ Microbiol 72: 2295-2297.

Nieto Penalver, C. G., Morin, D., Cantet, F., Saurel, O., Milon, A., \& Vorholt, J. A. (2006) Methylobacterium extorquens AM1 produces a novel type of acyl-homoserine lactone with a double unsaturated side chain under methylotrophic growth conditions. FEBS Lett 580: 561-567.

Ortori, C. A., Atkinson, S., Chhabra, S. R., Camara, M., Williams, P., \& Barrett, D. A. (2007) Comprehensive profiling of $\mathrm{N}$-acylhomoserine lactones produced by Yersinia pseudotuberculosis using liquid chromatography coupled to hybrid quadrupole-linear ion trap mass spectrometry. Anal Bioanal Chem 387: 497-511.

Paggi, R. A., Martone, C. B., Fuqua, C., \& Castro, R. E. (2003) Detection of quorum sensing signals in the haloalkaliphilic archaeon Natronococcus occultus. FEMS Microbiol Lett 221: 49-52.

Pedrós-Alió, C. (2006) Marine microbial diversity: can it be determined? Trends Microbiol 14: 257-263.

Ravn, L., Christensen, A. B., Molin, S., Givskov, M., \& Gram, L. (2001) Methods for detecting acylated homoserine lactones produced by Gram-negative bacteria and their application in studies of AHL-production kinetics. J Microbiol Meth 44: 239-251.

Riedel, K., Hentzer, M., Geisenberger, O., Huber, B., Steidle, A., Wu, H. et al. (2001) NAcylhomoserine-lactone-mediated communication between Pseudomonas aeruginosa and Burkholderia cepacia in mixed biofilms. Microbiol 147: 3249-3262.

Romero, M. (2010) Acyl homoserine lactone production and degradation by the fish pathogen Tenacibaculum maritimum, a member of the Cytophaga-FlavobacteriumBacteroides (CFB) group. FEMS Microbiol Lett 304: 131.

Rusch, D. B., Halpern, A. L., Sutton, G., Heidelberg, K. B., Williamson, S., Yooseph, S. et al. (2007) The Sorcerer II global ocean sampling expedition: Northwest Atlantic through eastern tropical Pacific. PLoS Biol 5: e77.

Schaefer, A. L., Greenberg, E., Oliver, C. M., Oda, Y., Huang, J. J., Bittan-Banin, G. et al. (2008) A new class of homoserine lactone quorum-sensing signals. Nature 454: 595-599. 
Schaefer, A. L., Taylor, T. A., Beatty, J. T., \& Greenberg, E. P. (2002) Long-chain acylhomoserine lactone quorum-sensing regulation of Rhodobacter capsulatus gene transfer agent production. $J$ Bacteriol 184: 6515-6521.

Sharif, D. I., Gallon, J., \& Smith, C. J. (2008) Quorum sensing in Cyanobacteria: Noctanoyl-homoserine lactone release and response, by the epilithic colonial cyanobacterium Gloeothece PCC6909. ISME J 2: 1171-1182.

Sheridan, C., Steinberg, D., \& Kling, G. (2002) The microbial and metazoan community associated with colonies of Trichodesmium spp.: a quantitative survey. J Plankton Res 24: 913-922.

Simmons, S. L., DiBartolo, G., Denef, V. J., Goltsman, D. S. A., Thelen, M. P., \& Banfield, J. F. (2008) Population genomic analysis of strain variation in Leptospirillum group II bacteria involved in acid mine drainage formation. PLoS Biol 6: e177.

Thiel, V., Kunze, B., Verma, P., Wagner-Dçbler, I., \& Schulz, S. (2009) New structural variants of homoserine lactones in bacteria. Chembiochem 10: 1861-1868.

Vroom, J. M., De Grauw, K. J., Gerritsen, H. C., Bradshaw, D. J., Marsh, P. D., Watson, G. K. et al. (1999) Depth penetration and detection of $\mathrm{pH}$ gradients in biofilms by two-photon excitation microscopy. Appl Environ Microbiol 65: 3502-3511.

Wagner-Dobler, I., Thiel, V., Eberl, L., Allgaier, M., Bodor, A., Meyer, S. et al. (2005) Discovery of complex mixtures of novel long-chain quorum sensing signals in freeliving and host-associated marine alphaproteobacteria. Chembiochem 6: 2195-2206.

Waters, C. M., \& Bassler, B. L. (2005) Quorum sensing: cell-to-cell communication in bacteria. Ann Rev Cell Dev Biol 21: 319-346.

Yates, E. A., Philipp, B., Buckley, C., Atkinson, S., Chhabra, S. R., Sockett, R. E. et al. (2002) N-Acylhomoserine lactones undergo lactonolysis in a pH-, temperature-, and acyl chain length-dependent manner during growth of Yersinia pseudotuberculosis and Pseudomonas aeruginosa. Infect Immun 70: 5635-5646. 


\title{
CHAPTER 4:
}

\section{TRICHODESMIUM THIEBAUTII COLONIES AT THE BERMUDA ATLANTIC TIME SERIES STATION ARE ASSOCIATED WITH DISTINCTIVE EPIBIONT POPULATIONS}

\begin{abstract}
Scientific interest in Trichodesmium has been fueled by its prominent role in the marine nitrogen cycle, however, it is often overlooked that Trichodesmium colonies are only one member of a complex consortia composed of bacteria, microzooplankton, and metazoa. Associated bacteria, in addition to improving the efficiency of nitrogen fixation, may also dictate the longevity of Trichodesmium blooms, and the fate of the carbon and nitrogen fixed by Trichodesmium. In this manner, the attached bacteria are themselves important players in the marine carbon cycle and of biogeochemical significance in their own right. In this study, we aimed to phylogenetically classify the communities associated with two morphological types of Trichodesmium colonies, tufts and puffs. Samples were obtained at the Bermuda Atlantic Time Series (BATS) site in the Sargasso Sea and data was compared with previously published clone libraries constructed from seawater at the same site. Communities associated with Trichodesmium tufts and puffs are distinct with respect to seawater and with respect to one another: no overlapping OTUs at the 97 percent similarity threshold were identified between puff and tuft samples, possibly indicating a role for heterotrophic bacteria in determining the colony morphology and
\end{abstract}


perhaps different ecosystem roles for tufts and puffs in the oceans. Overall, these data suggest that Trichodesmium possess an epibiotic microbial community distinctly different from that observed in bacterial picoplankton (interestingly, no archaeal or eukaryotic SSU rRNA gene sequences were detected). Moreover, Trichodesmium epibiotic communities display drastically lower diversity than bacterioplankton, supporting the idea that these assemblages are microbial hot spots in marine oligotrophic surface water environments.

\section{INTRODUCTION}

Heterotrophic bacteria colonize the surface of marine eukaryotic algae (Fisher et al., 1998; Sapp et al., 2007) and cyanobacteria (Herbst \& Overbeck, 1978; Paerl, 1982;

Siddiqui et al., 1992; Nausch, 1996; Sheridan et al., 2002; Stevenson \& Waterbury, 2006; Simmons et al., 2008) with very few exceptions. These associations are the subject of numerous studies and in many cases have been found to be quite specific (Paerl \& Gallucci, 1985; Fisher et al., 1998; Stevenson \& Waterbury, 2006; Tuomainen et al., 2006) and in some cases, symbiotic (Behrens et al., 2008). Bacteria colonize algae throughout their life-cycle and at all bloom stages and this colonization is not considered to be a sign of senescence or disease (Paerl et al., 1989; Sapp et al., 2007). The physical attachment and specific association between healthy algae and bacteria is suggestive that a functional mutualism has evolved between the two sets of organisms.

Scientific interest in the cyanobacterial genera Trichodesmium has largely been driven by their significant role as nitrogen-fixers (Capone et al., 1997; Karl et al., 1997). 
They are capable of fixing at least $80 \mathrm{Gt} \mathrm{N} \mathrm{y}^{-1}$ in extremely low-nutrient, oligotrophic marine environments; as such, they are understood to be a major source of fixed carbon and reduced nitrogen to these environments and fuel hotspots of microbial activity in surface waters (Letelier \& Karl, 1996; Capone et al., 1997; Carpenter et al., 1997)

The heterotrophic epibionts attached to nitrogen-fixing cyanobacteria may well achieve broad ecological impacts insomuch as they may influence the longevity of blooms (Tuomainen et al., 2006) and the efficiency of nitrogen fixation by contributing to the formation of anoxic microzones within cyanobacterial colonies (Herbst \& Overbeck, 1978; Paerl \& Pinckney, 1996). It is extraordinarily difficult to isolate Trichodesmium spp. in axenic culture, suggesting that they have evolved an essential relationship with their epibionts (Waterbury, 1991).

Without exception, heterotrophic bacteria and, frequently, filamentous cyanobacteria are observed attached to the surface of Trichodesmium spp. (Herbst \& Overbeck, 1978; Paerl et al., 1989; Siddiqui et al., 1992). Cell densities on Trichodesmium are reported to range from $8.2 \times 10^{8}$ cells $\mathrm{ml}^{-1}$ (Sheridan et al., 2002) up to $2.6 \times 10^{11}$ cells ml ${ }^{-1}$ (Paerl, 1982) which is 3-5 orders of magnitude more concentrated than planktonic bacteria in seawater. Epibiotic bacteria concentrate more heavily on Trichodesmium than on other particles, such as marine snow (Sheridan et al., 2002). Individual Trichodesmium cells typically form multi-cell trichomes which can bundle together in multi-trichome colonies (Carpenter et al., 2004). These colonies tend to be dominated by two morphologic types, a spherical "puff"-type and a fusiform "tuft"type. Bacteria on tuft-type colonies have been observed to occur in higher densities 
(Sheridan et al., 2002) and exhibit higher hydrolytic enzyme activity (Nausch, 1996) relative to those on puff-type colonies, although the diversity of metazoa and microzooplankton associated with puff-type colonies appears to be greater than that associated with tufts (Sheridan et al., 2002). The diversity of the bacterial community associated with Trichodesmium colonies and the basis for the discrepancy between microbial activities associated with tufts and puffs has not been examined.

The balance between primary production and heterotrophic remineralization processes is a major process in the ocean's carbon cycle. Attached bacteria consume nitrogen-rich organic exudates (Herbst \& Overbeck, 1978) and thereby retain nitrogen fixed by Trichodesmium in the euphotic layer of the ocean (Nausch, 1996). Nitrogen fixed by Trichodesmium fuels new production responsible for export production, a major vehicle for carbon export into the deep ocean. It has been speculated that in contrast to other types of marine particles or aggregates and despite their impact on export production, more of the Trichodesmium biomass is consumed in the ocean's surface layer (Nausch, 1996). Degradation of these colonies is likely mediated by attached bacteria and thus these organisms strongly influence the residence time of fixed nitrogen and carbon in the upper ocean as well as the composition of the material exported into the deep ocean.

Considering the global environmental significance of this specific algal-bacterial association, the role of ubiquitous heterotrophic epibionts associated with Trichodesmium spp. has been relatively understudied. Here we investigate the structure of the microbial epibiont community associated with Trichodesmium colonies collected in the Sargasso 
Sea employing a culture-independent $16 \mathrm{~S}$ rRNA gene sequence-based clone library survey. In the analysis of these clone libraries, we compare communities associated with two morphologically different types of colonies, tuft-type and puff-type, and consider the ecology which may serve to structure these communities.

\section{METHODS}

\section{Sample collection}

Trichodesmium spp. colonies were collected under non-bloom conditions (i.e. no obvious bloom was observed during any time of collection) in September 2008 on a cruise of the R/V Atlantic Explorer, at the Bermuda Atlantic Time Series (BATS) station. Aggregates were collected from the near surface (approximately the upper $20 \mathrm{~m}$ ) by a hand-held 130 $\mu \mathrm{m}$ plankton net and individual colonies were gently picked using an inoculating loop. Colonies were sequentially washed in three times with $0.2 \mu \mathrm{m}$-filtered seawater.

Individual colonies were preserved for DNA extraction. Colonies were preserved in SET buffer (0.75M Sucrose, 50mM Tris $\mathrm{pH} 8,40 \mathrm{mM}$ EDTA pH 8) and frozen in liquid $\mathrm{N}_{2}$ at sea and then transferred to a $-80^{\circ} \mathrm{C}$ freezer in Woods Hole.

\section{DNA extraction and Clone Library construction}

Clone libraries of bacterial 16S rRNA gene sequences were constructed from two samples. One sample corresponded to puff-type (PT) colonies, and one sample consisted of tuft-type (TT) colonies. Each sample was a composite of 10 colonies. DNA was obtained by phenol-extraction according to a protocol adapted from Marmur (1961). 
Aliquots of community Trichodesmium spp. DNA (25-100 ng) were added as template to Polymerase Chain Reactions (PCR) for amplification of the SSU rRNA gene sequence. Each PCR consisted of the following: $0.2 \mathrm{mM}$ dNTPs each, $0.5 \mathrm{uM}$ each forward primer 27F (5' AGAGTTTGATCMTGGCTCAG) and reverse primer 1492R (5' TACGGYTACCTTGTTACGACTT) (Invitrogen, Carlsbad, CA), 2 units "Easy A" thermostable proofreading polymerase (Stratagene, La Jolla, CA), for a $20 \mu \mathrm{L}$ final reaction volume. PCR cycles were as follows: an initial denaturation step of 2 minutes at $94^{\circ} \mathrm{C} ; 30$ seconds at $94^{\circ} \mathrm{C}, 30$ seconds at $55^{\circ} \mathrm{C}$, and 90 seconds at $72^{\circ} \mathrm{C}$ for a total of 30 amplification cycles. Reconditioning PCR was carried out to reduce heteroduplex formation (Thompson et al., 2002) as follows: initial reaction products were diluted tenfold, and re-amplified using parameters identical to the above, except that only three thermal cycles were performed. Triplicate PCR reactions were pooled and cloned into pCR 4-TOPO plasmid vectors using a TOPO TA cloning kit (Invitrogen, Carlsbad, CA). From each library 384 clones were picked and clone insert DNA was amplified by PCR consisting of the following: $0.2 \mathrm{mM}$ dNTPs each, $0.5 \mathrm{uM}$ each forward primer M13F (5'GTAAAACGACGGCCAG) and reverse primer M13R (5' CAGGAAACAGCTATGAC) (Invitrogen, Carlsbad, CA), and 1 U Paq5000 DNA polymerase (Stratagene, La Jolla, CA), for a $20 \mu \mathrm{L}$ final reaction volume. 35 reaction cycles were completed using the same parameters as above. In total, 384 bacterial SSU rRNA gene sequences were sequenced from each library. 


\section{PCR with archaeal and eukaryotic primers}

DNA extracts were screened for the presence of archaeal 16S rRNA genes and eukaryotic 18S rRNA genes. PCR was performed as described above, using Paq500 DNA

polymerase, with the following modifications: Archaeal DNA was amplified using Ar20F (5'-TTCCGGTTGATCCYGCCRG) and Ar958R (5'YCCGGCGTTGAMTCCAATT) primers which were allowed to anneal to DNA at 60 degrees. Eukaryotic DNA was amplified using EukF (5'AACCTGGTTGATCCTGCCAGT) and EukR (5'TGATCCTTCTGCAGGTTCACCTAC) primers which were allowed to anneal to DNA at 65 degrees. DNA from a fosmid template clone 4B7 (Group I Crenarchaea) (Stein et al., 1996) and a eukaryotic enrichment produced from seawater collected during HOTS cruise 179 (http://hahana.soest.hawaii.edu/hot/hot jgofs.html) at Station ALOHA at $25 \mathrm{~m}$ were used as positive amplification controls, respectively.

\section{Sequencing}

Clone inserts were sequenced using primer 27F. End-sequencing was performed offsite either by MWG-Operon (Huntsville, AL) or Agencourt Biosciences (Beverly, MA). 339 high-quality sequences were generated from the TT-colony library and 331 high-quality sequences were generated from the PT-colony library.

Raw sequences were aligned via the web-based SINA aligner (http://www.arbsilva.de/aligner/). Aligned sequences were imported into ARB (Ludwig, 2004) (version 07.12.07). Sequences were dereplicated at 97,99 , and 100 percent similarity threshold 
using the "percent similarity with gaps" algorithm within FastGroup II (Yu et al., 2006) (http://biome.sdsu.edu/fastgroup). Unique sequences were submitted to the Bellerophon server (Huber et al., 2004) (http://greengenes.lbl.gov/cgi-bin/nph-bel3_interface.cgi) in order to identify putative chimeras. Sequences submitted to Bellerophon were internally aligned using ClustalW and evaluated with a Huber-Hugenholtz correction and a window size of 200. Sequences identified as chimeric by Bellerophon were confirmed or disregarded with information from the Ribosomal Database Project (RDP II) chimera detection software (Cole et al., 2003) (http://rdp8.cme.msu.edu/cgis/chimera.cgi?su=SSU). Chimeric sequences were excluded from further analyses. Overall, 6 chimeric sequences were excluded from the PT library and one sequence was excluded from the TT library.

\section{Taxomomic assignments and phylogenetic analyses}

The Ribosomal Database Project II Classifier (Cole et al., 2003) was used to assign provisional taxonomic affiliations to 97 percent similar OTUs. BLASTn searches (Altschul et al., 1997) of the National Center for Biotechnology Information (NCBI) 16S rRNA gene sequence databases were performed to confirm taxonomic placements as many of our clones are relatively novel and thus yielded low bootstrap values in the automatic classifier. The proportions of major taxonomic groups were calculated (Figure 1 a-f) and the BLAST results are available in Supplemental Tables 1 and 2, all BLAST searches were performed with the GenBank database updated January 1, 2010. 
Rarefaction, coverage, and richness were all calculated for a 97 percent similarity threshold. Rarefaction results were calculated by Fast Group II (Yu et al., 2006). The coverage of our clone libraries (percentage of actual species richness that we detected in our clone libraries) was calculated according to Good (1953) and Chao (Chao \& Yang, 1993). The former estimates coverage related to relatively rare OTUs while the latter estimates coverage based on the abundance of dominant OTUs providing a lower and upper bound on coverage, respectively. Species richness was estimated using the Chao 1 nonparametric richness estimator (Chao, 1987) (Table 1), yielding the probable number of OTUs in the sample on the basis of singletons and doubletons detected in the clone library (Chao, 1987). Fast Group II also provided the Shannon-Wiener diversity index which takes into account not only species richness but the evenness of species distribution.

\section{Nucleotide sequence accession numbers}

All sequences were deposited in GenBank under accession numbers GU725472GU726134.

\section{RESULTS}

For comprehensive coverage and richness calculations, we binned sequences at a 97 percent sequence identity (PSI) threshold. Operational taxonomic units (OTUs), richness and diversity data are provided in Table 1 for 97,99 and 100 percent similar OTUs. The coverage of each library was estimated by two independent measures which rely on the 
occurrence of either rare (Good's coverage index) (Good, 1953) or abundant (Chao's coverage index) (Chao, 1987) OTUs. These estimates indicate that the PT library captured $75-95 \%$ of actual species richness and the TT library captured a similar range of $68-94 \%$ of actual richness. A complementary indicator of probable species richness (chao1) (Chao \& Yang, 1993) was calculated and the PT library yielded a probable 49 OTUs and the TT library yielded 32. Due to our library coverage being less than $100 \%$, actual measured richness was lower, 33 for the PT library and 22 for the TT. All of these values are likely low-estimates because we chose to analyze our samples as 97 PSI OTUs, and species richness estimates increase if calculations are considered at 99 or 100 PSI OTUs (see Table 1). The value of the Shannon-Wiener index, which considers the evenness of OTU distribution in addition to the OTU richness, is slightly higher in the PT library (1.9) compared to the TT library (1.6). Rarefaction curves were calculated for each library in order to determine the likelihood that our sampling effort was sufficient to produce an unbiased estimate of species richness as well as to reveal all the OTUs present in the samples (Figure 1). In the case of both libraries, the curves approach an asymptote, or saturation, which indicates that our sampling effort is acceptable and likely to yield reliable richness data.

\section{Eukaryotes and archaea}

No archaeal $16 \mathrm{~S}$ or eukaryotic $18 \mathrm{~S}$ sequences were amplified from either the TT or PT library. 


\section{Cyanobacteria}

Although this study was focused on the epibiont populations associated with Trichodesmium spp., we chose a DNA lysis method which effectively lysis a wide range of cells. As a result, we recovered high numbers of cyanobacterial 16S sequences and these provided a valuable insight into the cyanobacterial 'base' of the colonies.

Morphologically, the PT library was constructed from 10 colonies of the "puff"-type, and the TT library was constructed from 10 colonies of the "tuft"-type. 99\% of the cyanobacterial clones associated with the PT library were related to Trichodesmium thiebautii (AF013027) at 99 PSI. The other 1\% were most closely related to T. thiebautii, at a 95 PSI or higher level. The TT colonies contained a more diverse cyanobacterial population. $69 \%$ (150 clones) were related to T. thiebautii at a 99 PSI. However, $29 \%$ of the clones were most closely related (95 PSI) to an uncultured bacterium (EF630220) sharing 92 PSI with its nearest cultured relative in GenBank, a Limnothrix-like species (EF088338). Interestingly, both sequences derive from a Mycale laxissima sponge collected off a coral reef near Key Largo, FL (Mohamed et al., 2008). A phylogenetic tree detailing the taxonomic placement of cyanobacterial clone sequences is presented in Figure 4.

\section{Other epibiotic bacteria}

Non-cyanobacterial sequences in both clone libraries contained were dominated by Alphaproteobacteria and Flavobacteria. The two libraries displayed some class-level similarities, although there was significant heterogeneity at the family-level (Figure 2a). 
Flavobacteria composed $47 \%$ of the recovered non-cyanobacterial clones from the TT colonies. Sphingobacteria composed 35\% of remaining clones, Alphaproteobacteria composed another $12 \%$ of clones, and Firmicutes and the candidate phylum SR1 comprised the remaining $6 \%$ of the clones. Flavobacteria constituted a similar proportion (46\%) of PT non-cyanobacterial clones and Alphaproteobacteria composed $10 \%$ of total clones. The PT-colonies contained no Sphingobacteria, Firmicutes, or SR1. Instead, the rest of the PT library consisted of Chloroflexi (25\%), Gammaproteobacteria (12\%), Verrucomicrobia (5\%), Deltaproteobacteria (1\%) and unclassified sequences (1\%). Phylogenetic trees detailing the relationships between all PT and TT heterotrophic clone sequences are presented in Figures 5 and 6.

\section{Alphaproteobacteria}

Alphaproteobacteria are represented in both the PT and TT clone libraries.

Alphaproteobacteria associated with the TT-colonies were comprised of four families: Phyllobacteriaceae (50\%), Rhodospirillaceae (25\%), Rhodobacteraceae (17\%) and the Aurantimonadaceae (8\%). The PT library also contained representatives from the Rhodospirillaceae and Rhodobacteraceae which composed $7 \%$ and $66 \%$, respectively, of the total alphaproteobacterial clones. The remainder of the PT library comes from the order Rhizobiales: Rhodobiaceae (7\%) and Hyphomicrobiaceae (20\%). 


\section{Bacteroidetes}

All 73 flavobacterial clones isolated from the PT library are members of the

Flavobacteraceae. In contrast, only 3 of 56 Flavobacteriales clones retrieved from the TT library fall into the Flavobacteraceae. The other 43 are all related to the Cryomorphaceae. In addition to clones related to Flavobacteriales, the TT library also contains 36 clones which classify as Sphingobacteriales.

\section{DISCUSSION}

Trichodesmium spp. are notable in several respects. First, they thrive in the most oligotrophic regions of the world's oceans. Second, they fix nitrogen despite lacking the heterocystous cells that typically isolate oxygen-sensitive nitrogen-fixing enzymes from oxygen-producing photosynthetic processes. Finally, they are frequently observed to exist not as individual trichomes, but in colonies of cells which can occur in several distinct morphological varieties and in close association with numerous types of other microbes. The genome sequence of Trichodesmium erythraeum IMS101, the only fully sequenced Trichodesmium sp., is notable for its low gene coding density and high degree of horizontal gene transfer, both hallmarks of hosts benefitting from a mutualistic relationship (observation, personal communication with T. Mincer).

Trichodesmium spp. act as a surface in the upper ocean, host to a variety of bacteria, microzooplankton, and metazoa that would typically not thrive in harsh oligotrophic conditions. Much of the research interest in Trichodesmium stems from its role in the nitrogen cycle, however, comparably less work has been devoted to the 
Trichodesmium colony as a functional unit, a consortial community whose members would be unlikely to thrive in the absence of one another. In this study, we set out to investigate how the bacterial community associated with Trichodesmium spp. compares with that of ambient seawater and whether it varies between morphologic varieties.

On the basis of metazoan and microzooplankton data, it has been suggested that tuft and puff colonies form distinct niches for microbial communities (Sheridan et al., 2002). In our study, we were able to test this hypothesis as it relates to bacterial community structure. Although differences in bacterial density (Sheridan et al., 2002), enzyme activity (Nausch, 1996; Stihl et al., 2001) and redox conditions (Paerl et al., 1989) between the two colony types is suggestive of differences in microbial community structure, to our knowledge, this is the first phylogenetic investigation of the community structure of the total microbial epibionts associated with the two morphologic types.

Puff and tuft-type Trichodesmium colonies are a unique environment for marine microbes

Each of our samples was aggregated from 10 PT or TT colonies collected at the same time, and thus the clone libraries represent an average community associated with both colony types. We observed much greater species richness associated with our PT colonies. This result mirrors the richer community of microzooplankton and metazoa previously documented in puff-type colonies (Sheridan et al., 2002).

Both types of Trichodesmium colonies are host to communities of much lower species richness than is present in ambient seawater. Pommier and colleagues (Pommier 
et al., 2007) found that Sargasso Sea seawater collected at $5 \mathrm{~m}$ had an estimated richness (chao1) of 150 at the 97 PSI threshold. Using a dataset published by Carlson and colleagues (Carlson et al., 2008) we calculated the estimated richness of Sargasso Sea water collected at the BATS site from $40 \mathrm{~m}$ and determined a richness estimate of 68 at the 97 PSI threshold. Both of these values exceed that which we estimated on either PT colonies or TT colonies (49 and 32, respectively).

That the number of species associated with these colonies is lower than in the surrounding seawater suggests that the phycosphere of Trichodesmium selects for a specific subgroup of organisms which are not as well supported by ambient seawater. The nutrient and redox conditions of seawater vary quite dramatically from those in the interior of a Trichodesmium colony and different metabolic strategies are likely to be required to thrive in either one. In contrast to seawater, the interior of puff- and tuft-type colonies is more reducing (as measured by cellular tetrazolium salt reduction) and becomes anoxic during nighttime hours (Paerl et al., 1989).

The chao1 richness estimate is based on the low-abundance OTUs detected in a population. The high species richness of seawater reflects the great number of lowabundance free-living bacteria which may not actively participating in the biogeochemical cycling of elements in seawater (Pedrós-Alió, 2006). The bacteria which are abundant on Trichodesmium are likely originally "seeded" from these low-abundance members of the seawater community (i.e. the ones least likely to be represented in a cultivation-independent analysis of seawater). In fact, when we look for common seawater associated-bacteria in our Trichodesmium clone libraries, they are 
conspicuously absent. Trichodesmium epibionts are also likely to be inherited from mother to daughter cells and transferred between Trichodesmium colonies at unknown frequencies.

Typical Sargasso Sea seawater associated species (e.g. SAR11, SAR 86, Prochlorococcus or Synechococcus) were not detected in our libraries (Treusch et al., 2009). The OTUs we recovered cluster more closely with clones and isolates from benthic environments- biofilms associated with sponges and corals (e.g. numerous clone sequences detected in our Trichodesmium colony clone libraries are similar to those reported in Mohamed et al., 2008 and Sunagawa et al., 2009). Further, when we compared members of our library with common surface associated or algal associated organisms- for example, specific members of the Roseobacteria clade (Mayali et al., 2008; Wagner-Döbler et al., 2009), including an epibiont isolated from the surface of Trichodesmium in the Caribbean Sea (GenBank accession ACNZ01000108), we did not find close relationships. A quarter of clones recovered in the PT library shared 90 PSI or less with nearest neighbors in GenBank. The community associated with the TT-colonies is even more unusual in that 81 percent of clones share 90 PSI or less with their neighbors in GenBank. On the other hand, these communities are composed of only $21 \%$ and $9 \%$ respectively of OTUs which share 97 PSI or better with their nearest GenBank relatives. These results are similar to those obtained during a study of the bacterial flora associated with another filamentous cyanobacterium, Nodularia, which found that the majority of epibiont clones associated with Nodularia represented novel taxa (Tuomainen et al., 2006). Our data suggest that the phycosphere associated with Trichodesmium and 
other cyanobacteria is a novel ecological niche host to unexplored genetic diversity. If the species we observe on Trichodesmium indeed originate from the rare-members of the seawater microbial community, it serves to reason they would not be well represented in public databases which are biased towards the most abundant pelagic bacteria or abundant members of more 'traditional' benthic marine surfaces such as corals or sponges.

Archaea and eukaryotes were conspicuously absent from the Trichodesmium colonies. Euryarchaea may represent up to $30 \%$ of the microbial populations in the upper $100 \mathrm{~m}$ of the open ocean water column (Frigaard et al., 2006) and crenarchaea are one of the most abundant types of cell in the ocean when bathy- and mesopelagic populations are considered (Karner et al., 2001) and are important nitrifiers (Nicol \& Schleper, 2006). T. thiebautii is known to migrate vertically in the water column over the diel cycle (Villareal \& Carpenter, 1990) and Trichodesmium spp. have been observed at depths of $100 \mathrm{~m}$ and greater (Letelier \& Karl, 1998; Davis \& McGillicuddy Jr, 2006), the edge of the crenarchaeotal range (Karner et al., 2001). It is interesting that such an important nitrifying organism appears not to participate in nitrogen cycling in association with the ocean's most abundant nitrogen fixer. There have been many reports of eukaryotes associated with Trichodesmium colonies, however, they may be less tightly associated with the colonies and more easily separated during the sample preparation process. It is important to consider that our samples were collected under non-bloom conditions, and the contribution of archaea and eukaryotes might increase during a bloom event. 
An intercomparison of the epibiotic community associated with PT and TT samples We observed that in both our PT samples and TT samples, additional photosynthetic members contributed to the community. In the TT sample, additional photosynthetic members were distantly related to Limnothrix (92 PSI). Non-Trichodesmium cyanobacterial filaments have been reported in association with Trichodesmium colonies numerous times (Paerl et al., 1989; Siddiqui et al., 1992; Dyhrman et al., 2002; Hewson et al., 2009). These filaments have been described as Phormidium-like or Plectonemalike, although to our knowledge no absolute phylogenetic identification has been ascribed to this group. In one case where a distinction was made between colony morphologies, Sheridan and colleagues (2002) noted that they observed the matrix of puff colonies contained bacteria and microflagellates whereas the matrix of tuft colonies contained bacteria and cyanobacterial filaments (Sheridan et al., 2002). Siddiqui and co-authors (Siddiqui et al., 1992) noted that while they observed contaminating cyanobacterial filaments within both colony types, they were significantly more abundant and more reliably associated with tuft colonies. Thus, it may be common for tuft colonies to host additional cyanobacterial species (Sheridan et al., 2002). In contrast to our TT samples, we detected no cyanobacterial OTUs other than those related to T. thiebautii in the PT sample. In fact we detected significant numbers of OTUs related to other possible photosynthetic groups such as the phylum Chloroflexi (Zinder \& Dworkin, 2000) and members of the Roseobacter clade of the Alphaproteobacteria, known to be aerobic anoxygenic phototrophs (Buchan et al., 2005). 
The role of these additional phototrophs is unclear. They likely benefit from the buoyancy of Trichodesmium colonies and contribute to the mucilage layer which defines the colony (Siddiqui et al., 1992). The cyanobacterial filaments have been demonstrated to fix nitrogen (Siddiqui et al., 1992) so it is unlikely the cyanobacteria are benefitting from the rich source of fixed nitrogen in the Trichodesmium phycosphere. In addition, while it is difficult to remove heterotrophic epibionts from cultures of T. erythraeum or T. thiebautii, it does not appear to be difficult to remove the cyanobacteria; in clone libraries of three laboratory cultured, non-axenic Trichodesmium strains (IMS101, T. erythraeum tuft colony; K-11\#131, T. erythraeum tuft colony; H9-4A, T. thiebautii puff colony), no cyanobacterial OTUs other than those associated with Trichodesmium were detected (Hmelo, Van Mooy and Mincer, Appendix 1). From these data we might speculate that the relationship between Trichodesmium and its heterotrophic epibionts may be mutual where as the relationship between Trichodesmium and the 'other' cyanobacteria may be commensal.

It has become apparent that a 'typical' surface associate flora does not exist despite superficial patterns in phylogenetic associations. A large body of literature has been generated by the study of bacteria associated with eukaryotic microalgae. One can broadly generalize (at the class level) that eukaryotic microalgal cultures associate with Alphaproteobacteria, Gammaproteobacteria, and members of the FlavobacteriaSphingobacteria group (DeLong et al., 1993; Grossart et al., 2005; Sapp et al., 2007). In a recent transcriptomic effort exploring a natural Trichodesmium bloom north of Fiji, these same groups, Alphaproteobacteria, Gammaproteobacteria and Bacteroidetes, 
comprised roughly a quarter of non-cyanobacterial transcripts recovered during the daytime (Hewson et al., 2009). It is important to note that Hewson and co-workers collected Trichodesmium samples from a mature bloom and determined community composition using a different method than we employed in this study. Considering the limited number of instances in which the epibiont community associated with Trichodesmium has been described, their result serves as an interesting and infrequent point of comparison, so long as the preceding caveat is kept in mind. In contrast to the community composition described in the Hewson et al. study, Zehr (1995) identified Flavobacteria as the dominant members of the Trichodesmium epibiont community using fluorescently labeled probes for 16S rRNA genes and notably reported detecting no Alphaproteobacteria.

We detect abundant Alphaproteobacteria in both of our libraries. Despite the aforementioned results by Zehr and colleagues, the presence of Alphaproteobacteria is not surprising as many members of this group are opportunistic colonizers and copiotrophs (e.g. members of the Roseobacter clade) (Buchan et al., 2005; Dang et al., 2008). Members of the Rhodobacterales have been identified as ubiquitous early colonizers of surfaces in the oceans (Dang et al., 2008), and they comprise the majority of the alphaproteobacterial clones associated with the PT sample. It is striking that the Rhodobacterales contribute only a minor proportion of the clones associated with the TT sample.

The TT library is unusual in another regard: no gammaproteobacterial clones were sequenced from the TT library. This result is surprising given that 
Gammaproteobacteria are generally very common on marine surfaces, including particles and in particular, on algae (Fisher et al., 1998; Dang \& Lovell, 2000; Tuomainen et al., 2006; Sapp et al., 2007; Dang et al., 2008). Gammaproteobacteria were detected in the PT library, although they originate from Thiotrichales rather than Alteromonas, Marinobacter or Pseudoalteromonas as observed by Hewson and co-workers (Hewson et al., 2009). Although this observation may imply something interesting about the Trichodesmium phycosphere with respect to other surfaces, the functional properties of associated microbes remains unknown.

The TT library contained two clones related to the deeply branching candidate division SR1. There are no members of SR1 in cultivation and very few clones from this division have been recovered from marine environments (Davis et al., 2009). On the basis of their ecological distributions and association with bacteria known to be involved in sulfur transformations, it has been suggested that these bacteria are also involved in sulfur transformations in the environment although this assertion is tenuous until more data is available (Harris et al., 2004; Davis et al., 2009).

\section{Concluding thoughts}

As mentioned earlier, it is difficult to infer function from phylogenetic information alone, but a few generalizations can be inferred from the clone library composition. Many of the taxa present in these clone libraries may be metabolically flexible; that is, they are related to cultivars known to be capable of exploiting a range of redox conditions and carbon substrates. While additional physiological information about associated epibionts 
is clearly required to say with certainty that all of the major biogeochemical cycles are represented in Trichodesmium colonies, we can speculate that Trichodesmium-bacterial communities, in analogy to cyanobacterial microbial mat communities, function as true consortia, in which nitrogen, sulfur, and carbon are cycled within the colony associated community.

Despite distinct colony morphology, both the PT and TT colonies analyzed in this study are built around bundles of T. thiebautii. Bacterial density (Sheridan et al., 2002), enzyme activities (Nausch, 1996; Stihl et al., 2001) and redox gradients from the outside to the inside of the colony (Paerl et al., 1989) vary substantially between puff and tuft type colonies which suggests that the two types of colonies can host very different types of microbial communities. The libraries constructed in this study contain no common OTUs at the 97 PSI threshold. Our data are thus consistent with the preceding hypothesis and confirm that bacterial flora associated with PT colonies and TT colonies are quite different.

At this time, interpretation of these results relies to a degree on speculation, particularly since the colony to colony variation within the pooled samples from which our data originates remains unknown. However, such speculation generates new questions and testable hypotheses essential to improving our understanding of the ecological role of the epibiotic bacteria associated with Trichodesmium spp. In combination with the results of previous studies discussed earlier in this manuscript (e.g. those of Sheridan et al., 2002) the striking dissimilarity between the PT and TT samples suggest that the colony morphology may be influenced by the relative abundance and 
identity of bacterial epibionts associated with the colonies. Alternatively, the mutually exclusive flora associated with either colony type may indicate that the two types of colonies perform different ecosystem functions. Puffs and tufts exhibit different redox gradients (Paerl et al., 1989) and perhaps this difference translates into the recruitment of different bacteria suited to exploit each niche. Just as colony morphology may be influenced by the attached heterotrophic bacteria, colony morphology may influence the photosynthetic members. Relative to tuft-colonies, puffs are associated with greater bacterial density, a physically denser colony "core” (John Waterbury, personal communication), and a greater amount of exopolysaccharide material (John Waterbury, personal communication). These parameters can affect the extent of shading within the colony. The extent of internal shading may in turn influence whether other phototrophs colonize the TT community, as fits our observations (see Figure 3).

Biofilm communities are typically highly structured and efficiently regulated. The bacterial communities associated with Trichodesmium compose biofilms, and can be expected to be strongly internally regulated by its constituent members. The community composition is likely to be influenced by bacterial-bacterial interactions such as competition for resources, secondary metabolite production, and cooperation. It is likely that Proteobacteria hosted by Trichodesmium use the same types of cooperative strategies employed by other marine biofilm-forming bacteria (e.g. quorum sensing) (Dang et al., 2008).

Bacteria associate with Trichodesmium colonies are reported to occur at densities of $10^{7}-10^{9}$ cells $\mathrm{ml}^{-1}$ (Sheridan et al., 2002) which can support cell-cell interactions via 
quorum sensing (QS) (Hmelo \& Van Mooy, 2009). In fact, QS has been observed in stromatolites, another type of cyanobacteria-heterotrophic bacteria consortia (Decho et al., 2009). In addition to structuring the bacterial epibiont community, QS might play a role in attracting microzooplankton or metazoa to the colonial community. AHLproduction in biofilms has been previously observed to attract Ulva propagules to seaweed and is hypothesized to act as a chemo-attractant (Tait et al., 2005). Colonization of Trichodesmium by QS bacteria may thus affect when the colonies are colonized by eukaryotes and which eukaryotes choose to settle.

The data we present here indicate that Trichodesmium-associated bacterial communities are distinct from other marine pelagic and benthic microbial communities. The adaptations which provide these organisms with a competitive advantage in the Trichodesmium phycosphere may be associated with novel metabolic pathways, secondary metabolite production, or detoxification strategies. These data provide a phylogenetic basis for investigations of these adaptive strategies, in particular, the cooperative social strategies (QS) of Trichodesmium-associated bacterial communities. 


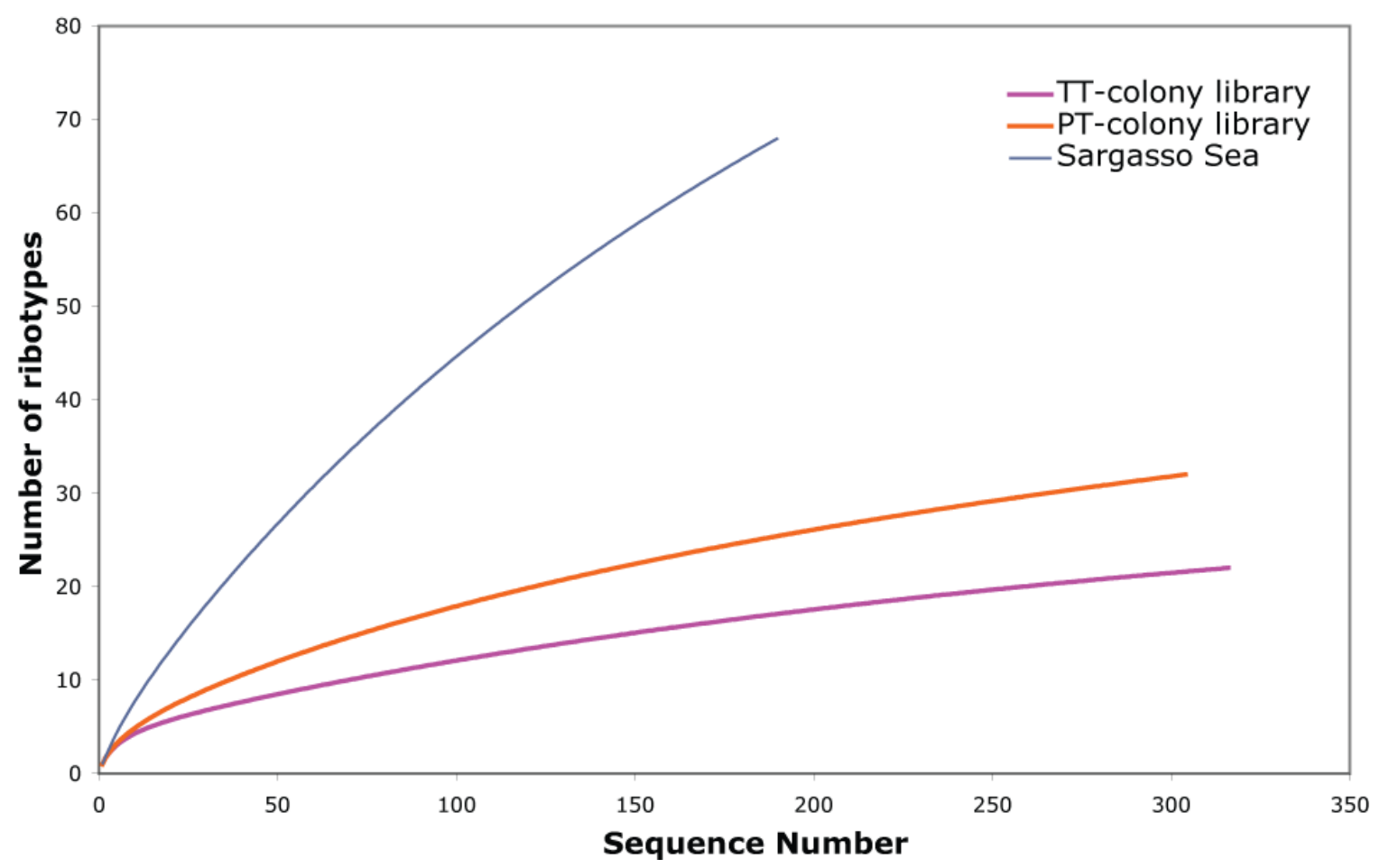

Figure 1. Rarefaction curve of PT and TT $16 \mathrm{~S}$ rDNA clone libraries generated in this study as well as a Sargasso Sea (BATS site, $40 \mathrm{~m}$ depth, Carlson et al., 2008) clone library data, summarized in Figure 2. 
a.

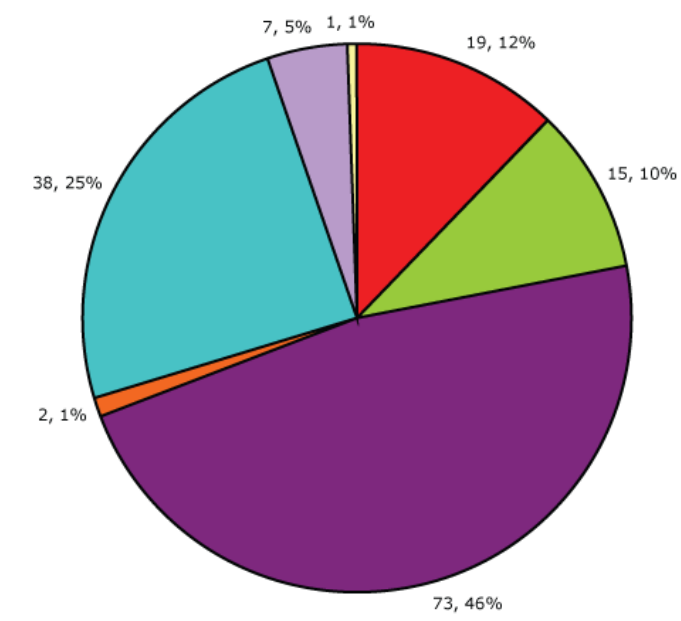

$n=155$

b. Sargasso Sea bacterioplankton

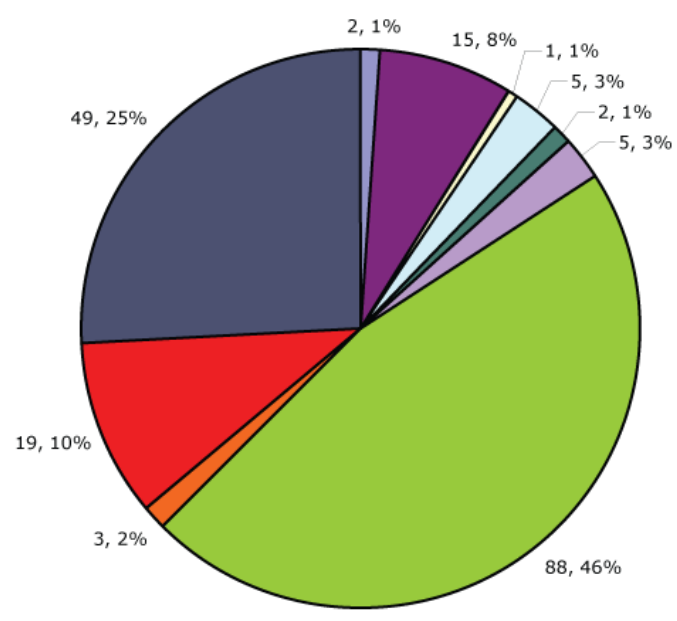

Tuft-type colonies

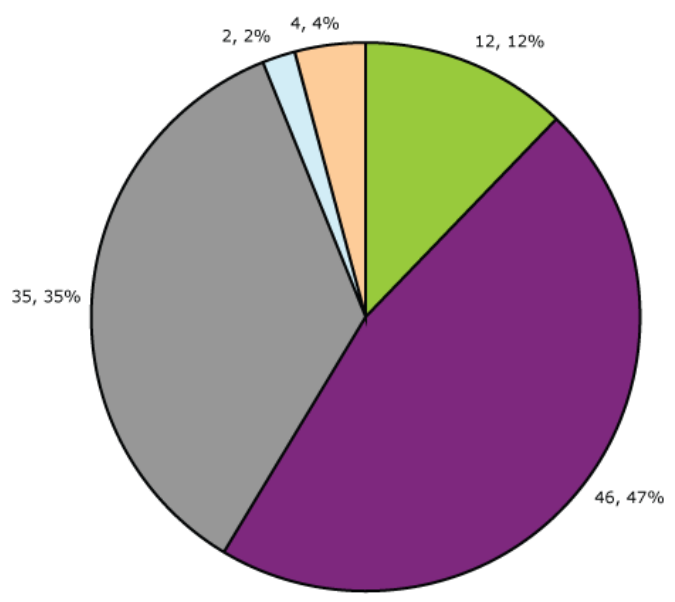

$$
n=99
$$

$\square$ Gammaproteobacteria

$\square$ Alphaproteobacteria

$\square$ Flavobacteria

$\square$ Sphingobacteria

$\square$ Deltaproteobacteria

$\square$ Bacteroidetes, unclassified

$\square$ Verrucomicrobia

$\square$ Unclassified bacteria

$\square$ Chloroflexi

$\square$ Phylum Firmicutes

$\square$ Phylum SR1

$\square$ Cyanobacteria

$\square$ Deferribacteres

$\square$ Firmicutes

$\square$ Lentisphaerae

$\square$ Actinobacteria

$$
n=189
$$

Figure 2. Class-level phylogenetic composition of (a) PT and TT ebibiont communities and (b) Sargasso Sea bacterioplankton (for comparison). Values listed adjacent to each 'wedge' of the pie chart provide the number of clones in that category, followed by the percentage of the total non-cyanobacterial clones recovered. The number of noncyanobacterial clones recovered is listed underneath each chart. 
Figure 3. Phylogenetic composition of PT and TT epibiont communities (in the lefthand and right-hand column, respectively). (a) Distribution of clones related to Cyanobacteria in PT colonies. Values listed adjacent to each 'wedge' of the pie chart provide the number of clones in that category, followed by the percentage of the total cyanobacterial clones recovered. The number of cyanobacterial clones recovered is listed underneath each chart. (b) Family-level distribution of clones within the class Alphaproteobacteria. (c) Family-level distribution of clones within the class Bacteroidetes. In (b) and (c) values listed adjacent to each 'wedge' of the pie chart provide the number of clones in that category, followed by the percentage of the total non-cyanobacterial clones recovered. The number of non-cyanobacterial clones recovered is listed underneath each chart. 
a.

Puff-type colonies

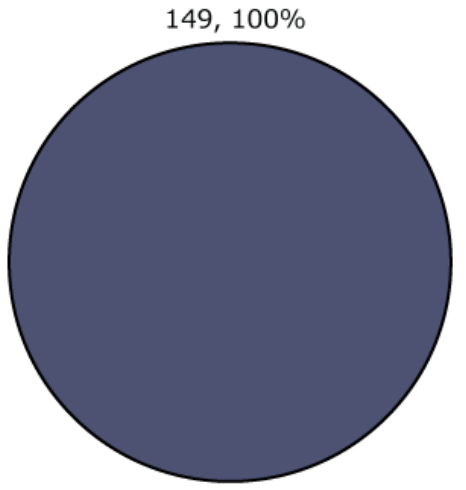

$n=149$

b.

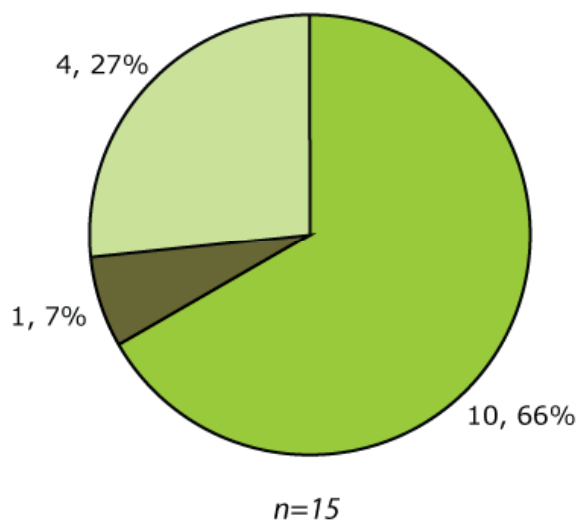

c.

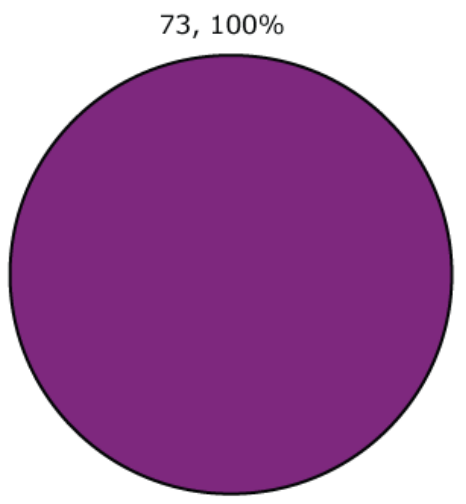

$n=73$
Tuft-type colonies

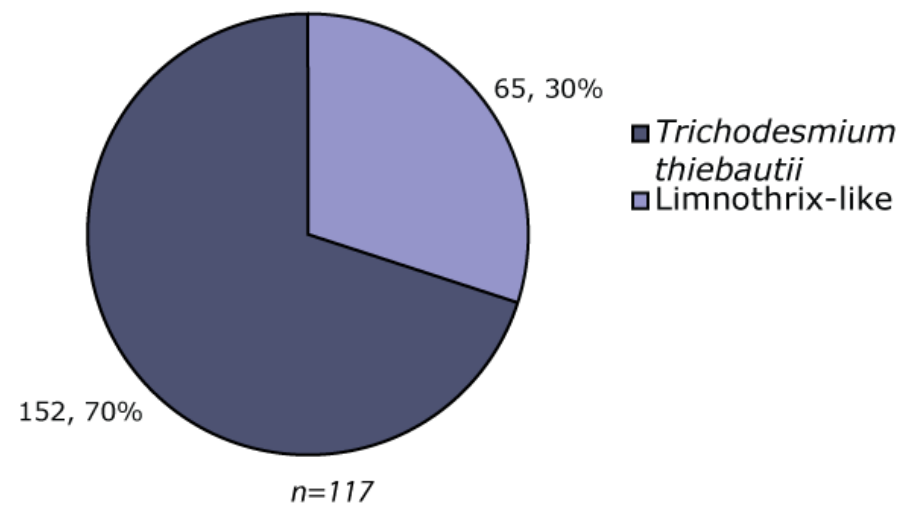

口Flavobacteriales 口Sphingobacteriales

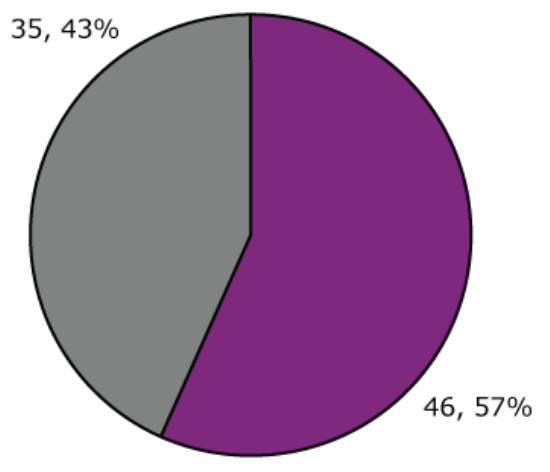

$n=81$
口Rhodobacterales 口Rhodospirillales 口Rhizobiales 


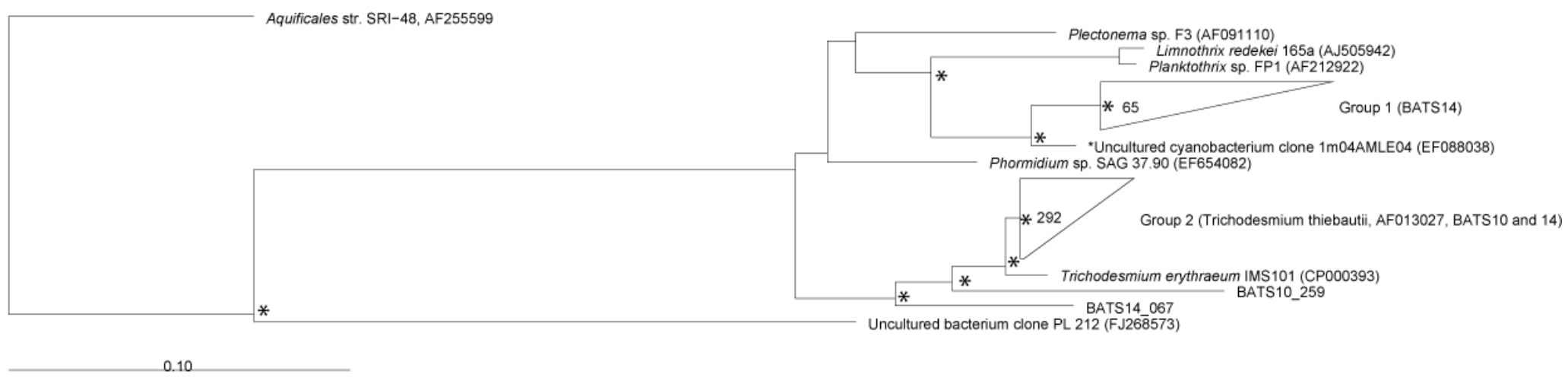

Figure 4. Phylogenetic tree containing cyanobacterial sequences recovered from Trichodesmium colonies in this study. Thus tree was created using Neighbor Joining algorithm in ARB and bootstrapped 1000 times using Phylip (v 3.68). Asterisks indicate bootstrap values of $60 \%$ or better. Sequences generated in this study are indicated by boldface type. Accession numbers are in parentheses following all sequences. BATS10 identifies PT samples and BATS14 identifies TT samples. 
Figure 5. Phylogenetic tree containing proteobacterial sequences recovered from Trichodesmium colonies in this study. Thus tree was created using Neighbor Joining algorithm in ARB and bootstrapped 1000 times using Phylip (v 3.68). Asterisks indicate bootstrap values of $60 \%$ or better. Sequences generated in this study are indicated by boldface type. Accession numbers are in parentheses following all sequences. BATS10 identifies PT samples and BATS14 identifies TT samples. All of the sequences collapsed into Group 1 differ by less than 3\%.

Figure 6. (a) Phylogenetic tree containing sequences which are not categorized as cyanobacterial or proteobacterial (namely, members of Bacteroidetes, Verrucomicrobia, Cloroflexi, Firmicutes, and the candidate phylum SR1) recovered from Trichodesmium colonies in this study. Thus tree was created using Neighbor Joining algorithm in ARB and bootstrapped 1000 times using Phylip (v 3.68). Asterisks indicate bootstrap values of $60 \%$ or better. Sequences generated in this study are indicated by boldface type. Accession numbers are in parentheses following all sequences. BATS10 identifies PT samples and BATS14 identifies TT samples. Sequences which are collapsed into Groups 1 and 3 differ by less than 3\%. Sequences in Group 2 differ by $4.9 \%$ and sequences in Group 4 differ by 3.5\%. (b) Expanded tree detailing the individual OTUs contained within Group 2. Asterisks indicate bootstrap values of $60 \%$ or better. (c) Expanded tree detailing the individual OTUs contained within Group 4. Asterisks indicate bootstrap values of $70 \%$ or better. 


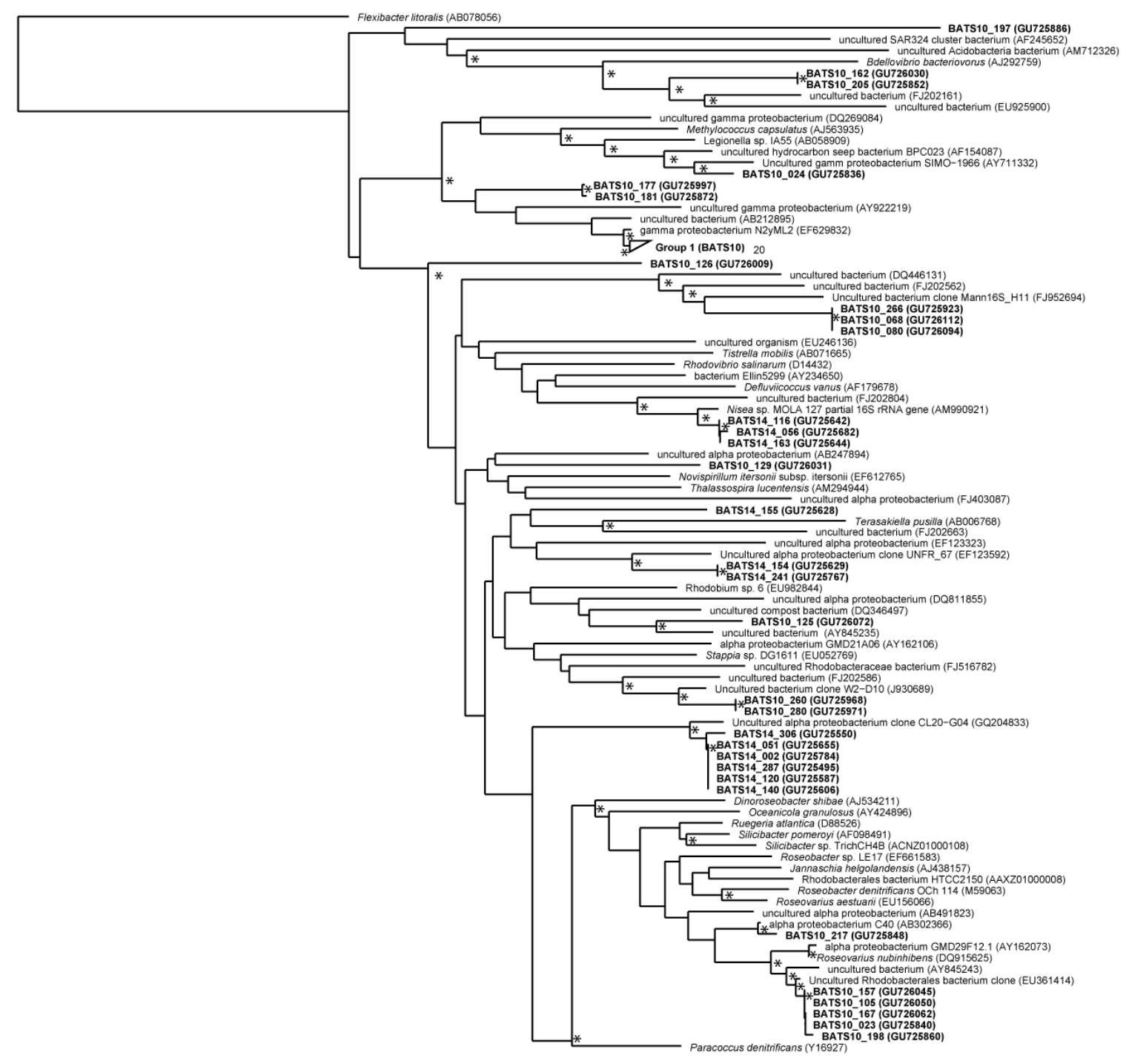

Figure 5 
Figure 6

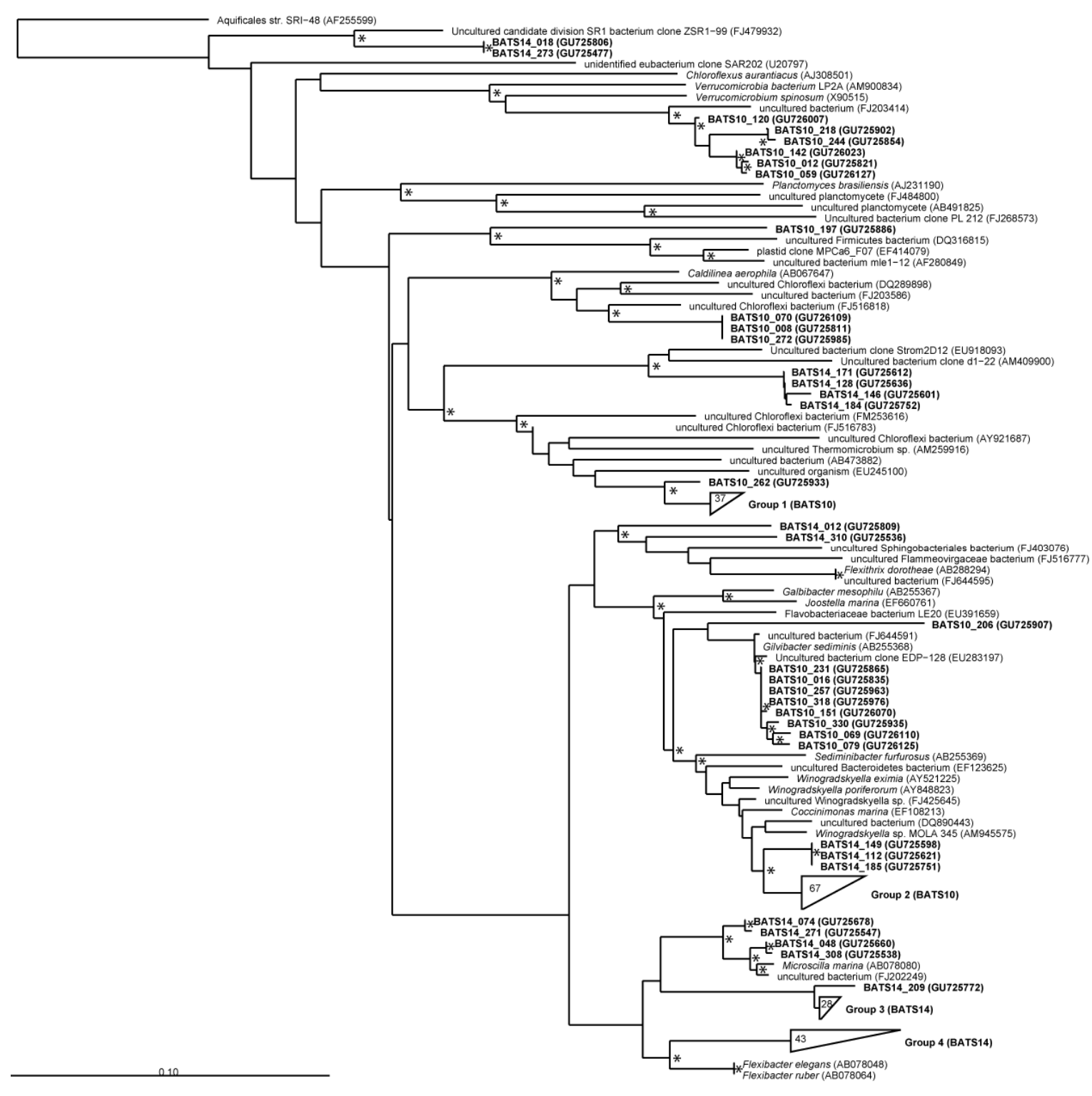




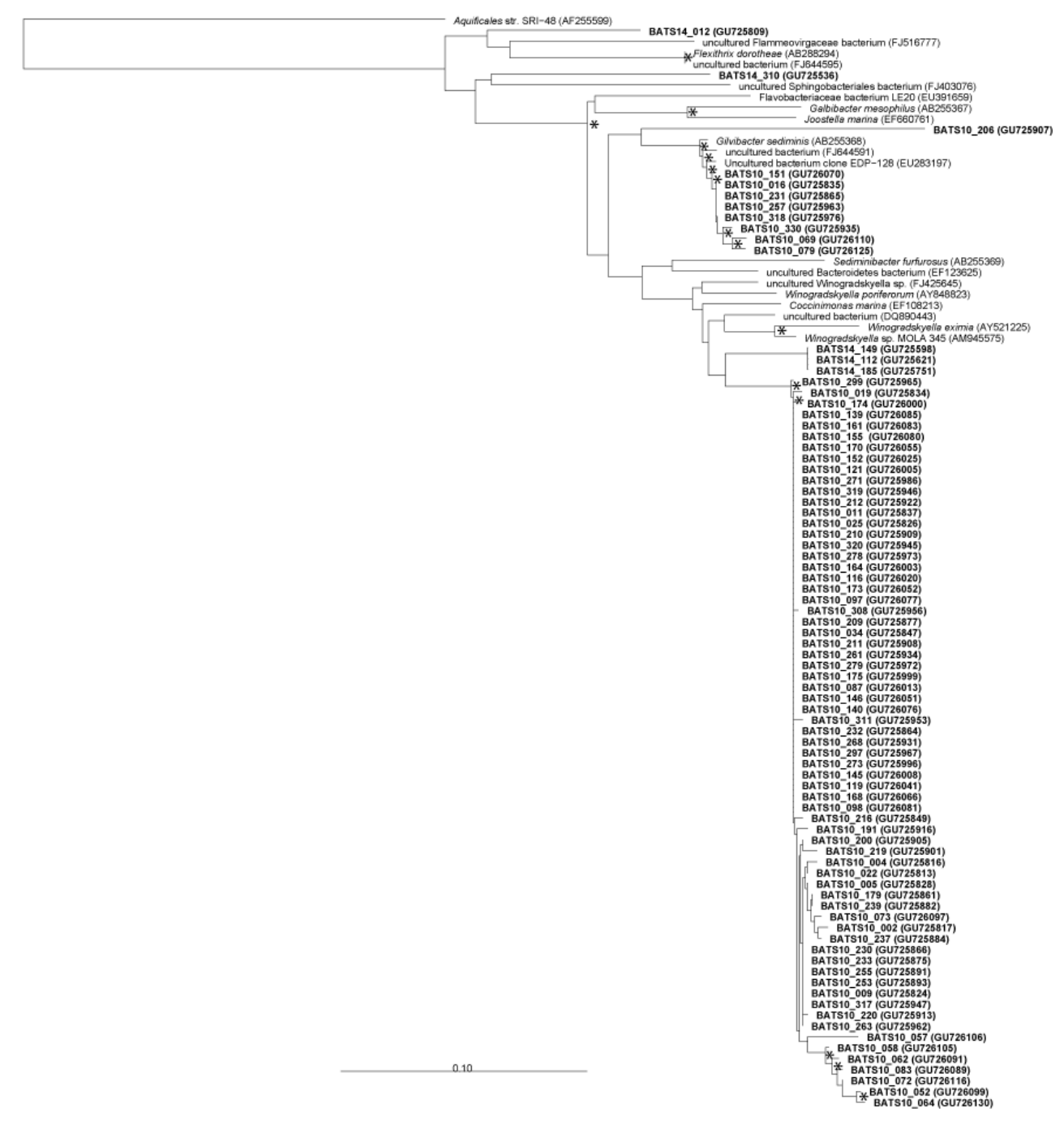




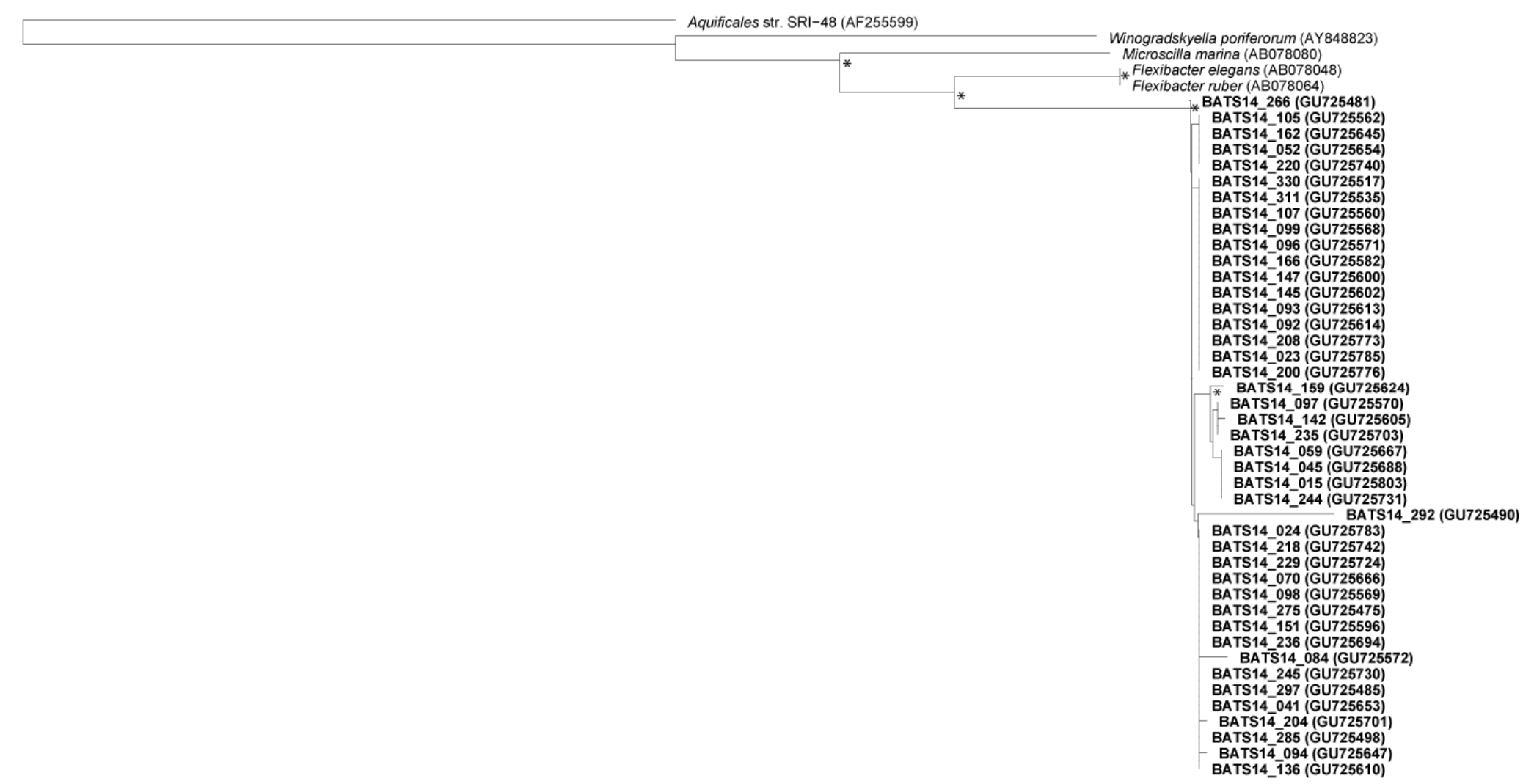

Figure 6b 


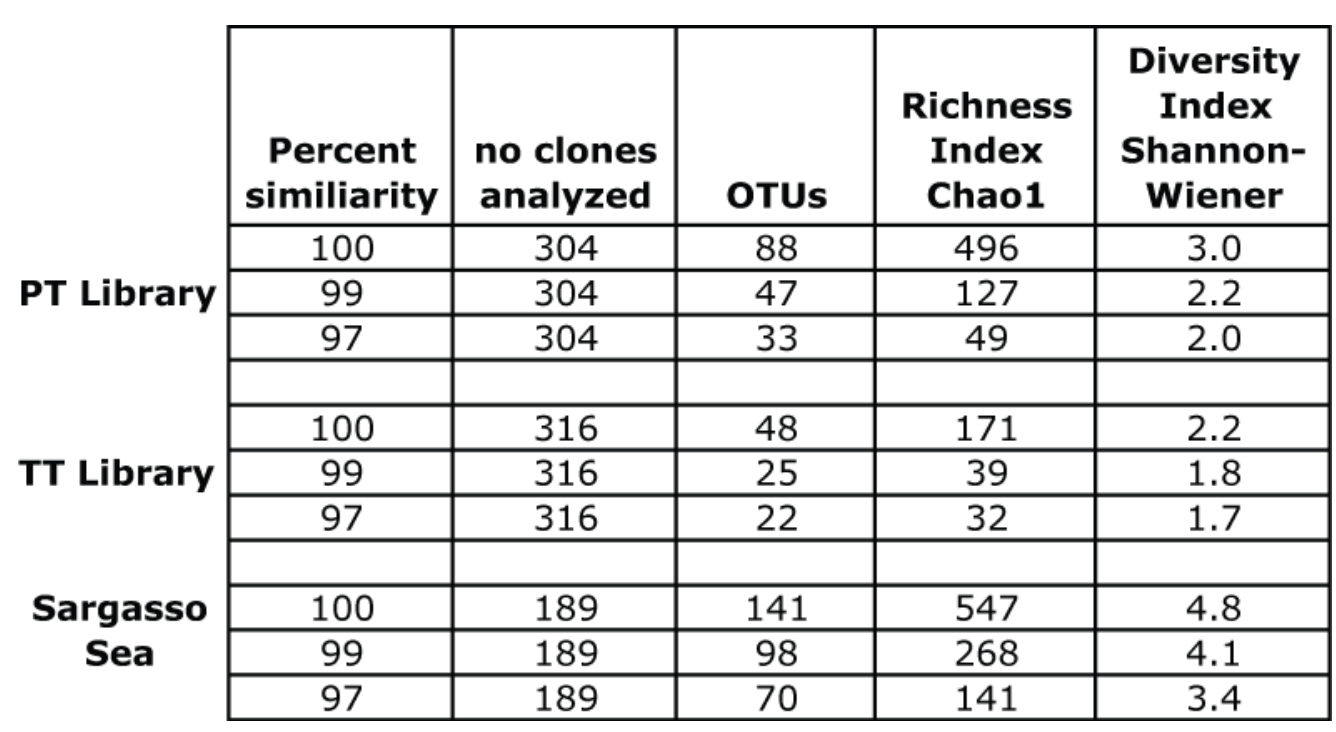

Table 1. Statistical description of PT, TT, and Sargasso Sea bacterioplankton clone libraries. OTUs, the Chao1 richness index, and the Shannon-Wiener diversity index were all calculated using the FastGroup II website which is described in the Methods. The number of OTUs and the values of the Chao1 and Shannon-Wiener indices are calculated at the 97, 99, and 100 percent sequence identity threshold (PSI). The results of the 97 PSI analysis are described in detail in the text. 
Supplemental Table 1. Nearest GenBank neighbors of 97 PSI OTUs present within 16S rDNA clone libraries constructed from DNA extracted from tuft-type (TT) Trichodesmium colonies. In cases where the nearest neighbor is an uncultivated organism, the nearest cultivated organism is included as well.

Supplemental Table 2. Nearest GenBank neighbors of 97 PSI OTUs present within 16S rDNA clone libraries constructed from DNA extracted from puff-type (PT) Trichodesmium colonies. In cases where the nearest neighbor is an uncultivated organism, the nearest cultivated organism is included as well 


\section{Supplemental Table 1}

\begin{tabular}{|c|c|c|c|c|c|c|c|}
\hline $\begin{array}{c}\text { Clone ID } \\
\text { (BATS14」) }\end{array}$ & $\begin{array}{c}\text { Accession } \\
\text { no. }\end{array}$ & Sequence ID of nearest BLAST match & $\begin{array}{c}\text { Accession no. } \\
\text { (BLAST } \\
\text { match) } \\
\end{array}$ & PSI & $\begin{array}{c}\text { Number of } \\
\text { bases } \\
\text { compared }\end{array}$ & Bit score & $\begin{array}{c}\text { Number of } \\
\text { clones } \\
\text { recovered }\end{array}$ \\
\hline 163 & GU725644 & Uncultured alpha proteobacterium partial 16S rRNA gene, clone bc4.49 & FM896960 & 99 & 431 & 780 & 3 \\
\hline 163 & GU725644 & Nisaea sp. MOLA 147 partial 16S rRNA gene, culture collection MOLA:147 & AM990921 & 98 & 431 & 763 & \\
\hline 051 & GU725655 & Uncultured alpha proteobacterium clone CL20-G04 16S ribosomal RNA gene & GQ204833 & 98 & 431 & 758 & 6 \\
\hline 051 & GU725655 & Paracoccus versutus strain GW1 $16 \mathrm{~S}$ ribosomal RNA gene & GU111570 & 93 & 433 & 630 & \\
\hline 154 & GU725629 & Uncultured alpha proteobacterium clone UNFR_67 16S ribosomal RNA gene & EF123592 & 95 & 428 & 673 & 2 \\
\hline 155 & GU725628 & Stappia sp. DG1611 16S ribosomal RNA gene & EU052769 & 93 & 432 & 638 & 1 \\
\hline 186 & GU725764 & Uncultured cyanobacterium clone 1m04AMLE04 16S ribosomal RNA gene & EF630220 & 96 & 433 & 726 & 64 \\
\hline 186 & GU725764 & Limnothrix sp. CENA110 $16 \mathrm{~S}$ ribosomal RNA gene & EF088338 & 92 & 439 & 610 & \\
\hline 087 & GU725633 & Trichodesmium thiebautii $16 \mathrm{~S}$ ribosomal RNA gene & AF013027 & 99 & 433 & 795 & 150 \\
\hline 261 & GU725545 & Uncultured cyanobacterium clone 1m04AMLE04 16S ribosomal RNA gene & EF630220 & 93 & 435 & 632 & 1 \\
\hline 261 & GU725545 & Limnothrix sp. CENA110 16 S ribosomal RNA gene & EF088338 & 89 & 440 & 532 & \\
\hline 317 & GU725529 & Trichodesmium thiebautii $16 \mathrm{~S}$ ribosomal RNA gene & AF013027 & 97 & 433 & 739 & 1 \\
\hline 217 & GU725743 & Trichodesmium thiebautii $16 \mathrm{~S}$ ribosomal RNA gene & AF013027 & 92 & 436 & 628 & 1 \\
\hline 292 & GU725490 & Flexibacter ruber gene for $16 \mathrm{~S}$ rRNA, strain:IFO 16675 & AB078064 & 87 & 474 & 531 & 1 \\
\hline 204 & GU725701 & Flexibacter ruber gene for $16 \mathrm{~S}$ rRNA, strain:IFO 16675 & AB078064 & 89 & 474 & 592 & 42 \\
\hline 112 & GU725621 & Winogradskyella sp. K7-7 16S ribosomal RNA gene & FJ425226 & 93 & 369 & 682 & 2 \\
\hline 149 & GU725598 & Winogradskyella sp. K7-7 $16 \mathrm{~S}$ ribosomal RNA gene & FJ425226 & 93 & 474 & 689 & 1 \\
\hline 328 & GU725519 & Microscilla marina gene for $16 \mathrm{~S}$ rRNA, strain:IFO 16560 & AB078080 & 87 & 793 & 893 & 28 \\
\hline 308 & GU725538 & Microscilla marina gene for $16 \mathrm{~S}$ rRNA, strain:IFO 16560 & AB078080 & 96 & 753 & 1221 & 2 \\
\hline 012 & GU725809 & Flexibacter aggregan s gene for 16S rRNA, strain: IAM 14894 & AB288294 & 89 & 789 & 953 & 1 \\
\hline 310 & GU725536 & Uncultured Sphingobacteriales bacterium clone MD2.27 & FJ403076 & 86 & 790 & 808 & 1 \\
\hline 209 & GU725772 & Microscilla marina gene for $16 \mathrm{~S}$ rRNA, strain:IFO 16560 & AB078080 & 87 & 735 & 819 & 1 \\
\hline 271 & GU725547 & Microscilla marina gene for $16 \mathrm{~S}$ rRNA, strain:IFO 16560 & AB078080 & 94 & 728 & 1112 & 2 \\
\hline 171 & GU725612 & Uncultured bacterium partial 16S rRNA gene, clone d1-22 & AM409900 & 89 & 738 & 933 & 3 \\
\hline 171 & GU725612 & Uncultured bacterium clone Strom2D12 16S ribosomal RNA gene & EU918093 & 89 & 737 & 931 & \\
\hline 184 & GU725752 & Uncultured bacterium clone Strom2D12 16S ribosomal RNA gene & EU918093 & 89 & 738 & 928 & 1 \\
\hline 273 & GU725477 & Uncultured candidate division SR1 bacterium clone ZSR1-99 & FJ479932 & 90 & 675 & 869 & 2 \\
\hline
\end{tabular}




\section{Supplemental Table 2}

\begin{tabular}{|c|c|c|c|c|c|c|c|}
\hline $\begin{array}{l}\text { Clone ID } \\
\text { (BATS10」) }\end{array}$ & $\begin{array}{c}\text { Accession } \\
\text { no. }\end{array}$ & Sequence ID of nearest BLAST match & $\begin{array}{c}\text { Accession no. } \\
\text { (BLAST } \\
\text { match) }\end{array}$ & PSI & $\begin{array}{c}\text { Number of } \\
\text { bases } \\
\text { compared }\end{array}$ & Bit score & $\begin{array}{c}\text { Number of } \\
\text { clones } \\
\text { recovered }\end{array}$ \\
\hline 125 & GU726072 & Uncultured bacterium clone 31P16 $16 \mathrm{~S}$ ribosomal RNA gene & AY845235 & 96 & 700 & 621 & 1 \\
\hline 125 & GU726072 & Brucella sp. HJ114 16S ribosomal RNA gene, partial sequence & AY234650 & 92 & 706 & 542 & \\
\hline 217 & GU725848 & Uncultured bacterium clone SHFG540 16S ribosomal RNA gene & FJ203138 & 98 & 627 & 1120 & 1 \\
\hline 217 & GU725848 & Alpha proteobacterium C40 gene for $16 \mathrm{~S}$ rRNA & AB302366 & 98 & 627 & 1120 & \\
\hline 312 & GU725952 & Uncultured alpha proteobacterium gene for $16 \mathrm{~S}$ rRNA, clone: pKB7B-1 & AB247894 & 93 & 347 & 641 & 2 \\
\hline 312 & GU725952 & Aquaspirillum itersonii subsp. itersonii strain LMG 4337 16S ribosomal RNA gene & EF612765 & 92 & 428 & 614 & \\
\hline 266 & GU725923 & Uncultured bacterium clone Mann16S_H11 16S ribosomal RNA gene & FJ952694 & 92 & 667 & 944 & 3 \\
\hline 266 & GU725923 & Marine alpha proteobacterium RS.Sph.017 16S ribosomal RNA gene & DQ097291 & 91 & 670 & 894 & \\
\hline 126 & GU726009 & Rhodobium sp. $616 \mathrm{~S}$ ribosomal RNA gene & EU982844 & 89 & 764 & 961 & 1 \\
\hline 157 & GU726045 & Uncultured Rhodobacterales bacterium clone HF770_42O01 SSU rRNA gene & EU361414 & 98 & 744 & 1315 & 5 \\
\hline 157 & GU726045 & Roseovarius nubinhibens strain DSM15170 16S ribosomal RNA gene & DQ915625 & 97 & 744 & 1277 & \\
\hline 260 & GU725968 & Uncultured bacterium clone W2-D10 16S SSU rRNA gene & FJ930689 & 96 & 630 & 1061 & 2 \\
\hline 260 & GU725968 & Alpha proteobacterium $\mathrm{A} 30$ gene for $16 \mathrm{~S}$ rRNA & AB302381 & 94 & 651 & 959 & \\
\hline 124 & GU726028 & Gamma proteobacterium N2yML2 16S ribosomal RNA gene, & EF629832 & 99 & 704 & 1284 & 17 \\
\hline 124 & GU726028 & Gamma proteobacterium KMM 3900 gene for 16 S ribosomal RNA & AB500095 & 96 & 752 & 1223 & \\
\hline 177 & GU725997 & Gamma proteobacterium N2yML2 $16 \mathrm{~S}$ ribosomal RNA gene & EF629832 & 92 & 701 & 989 & 1 \\
\hline 024 & GU72583 & Uncultured gamma proteobacterium clone SIMO-1966 16S rRNA gene & AY711332 & 96 & 746 & 1238 & 1 \\
\hline 024 & GU72583 & Legionella sp. IA55 gene for 16S rRNA & AB058909 & 91 & 749 & 1024 & \\
\hline 300 & GU725964 & Trichodesmium thiebautii $16 \mathrm{~S}$ ribosomal RNA gene & AF013027 & 99 & 711 & 1310 & 141 \\
\hline 147 & GU726035 & Trichodesmium thiebautii 16S ribosomal RNA gene & AF013027 & 99 & 711 & 1293 & 2 \\
\hline 304 & GU725960 & Trichodesmium thiebautii 16 S ribosomal RNA gene & AF013027 & 95 & 548 & 881 & 1 \\
\hline 184 & GU725887 & Trichodesmium thiebautii $16 \mathrm{~S}$ ribosomal RNA gene & AF013027 & 99 & 562 & 1009 & 1 \\
\hline 330 & GU725935 & Uncultured bacterium clone EDP-128 $16 \mathrm{~S}$ ribosomal RNA gene & EU283197 & 98 & 658 & 1171 & 8 \\
\hline 330 & GU725935 & Gilvibacter sp. MOLA 433 partial 16S rRNA gene & AM990700 & 98 & 658 & 1166 & \\
\hline 073 & GU726097 & Uncultured bacterium clone livecontrolB18 $16 \mathrm{~S}$ ribosomal RNA gene & FJ264752 & 93 & 737 & 1068 & 1 \\
\hline 073 & GU726097 & Coccinimonas marina strain IMCC1846 16S ribosomal RNA gene & EF108213 & 92 & 732 & 1057 & \\
\hline 052 & GU726099 & Uncultured bacterium clone 654 16S ribosomal RNA gene & FJ223527 & 92 & 670 & 953 & 4 \\
\hline 052 & GU726099 & Winogradskyella sp. MOLA 413 partial 16S rRNA gene & AM990680 & 92 & 669 & 937 & \\
\hline 174 & GU726000 & Uncultured bacterium clone pt181 16S ribosomal RNA gene & DQ890443 & 94 & 710 & 1072 & 1 \\
\hline 174 & GU726000 & Winogradskyella sp. MOLA 345 partial 16S rRNA gene & AM945575 & 93 & 715 & 1055 & \\
\hline 206 & GU725907 & Gilvibacter sediminis gene for $16 \mathrm{~S}$ rRNA & AB255368 & 99 & 534 & 957 & 1 \\
\hline 253 & GU725893 & Uncultured bacterium clone pt181 16S ribosomal RNA gene & DQ890443 & 94 & 718 & 1081 & 3 \\
\hline 253 & GU725893 & Winogradskyella sp. MOLA 345 partial 16S rRNA gene & AM945575 & 93 & 723 & 1064 & \\
\hline
\end{tabular}


Supplemental Table 2 (cont'd)

\begin{tabular}{|c|c|c|c|c|c|c|c|}
\hline $\begin{array}{l}\text { Clone ID } \\
\text { (BATS10」) }\end{array}$ & $\begin{array}{c}\text { Accession } \\
\text { no. }\end{array}$ & Sequence ID of nearest BLAST match & $\begin{array}{l}\text { Accession no. } \\
\text { (BLAST } \\
\text { match) }\end{array}$ & PSI & $\begin{array}{l}\text { Number of } \\
\text { bases } \\
\text { compared }\end{array}$ & Bit score & $\begin{array}{l}\text { Number of } \\
\text { clones } \\
\text { recovered }\end{array}$ \\
\hline 026 & GU725822 & Uncultured bacterium gene for $16 \mathrm{~S}$ rRNA, partial sequence, clone: SS_04 & AB473882 & 90 & 713 & 944 & 34 \\
\hline 272 & GU725985 & Uncultured Chloroflexi bacterium clone TDNP_Bbc97_69_2_134 16S rRNA gene & FJ516818 & 92 & 724 & 1029 & 3 \\
\hline 262 & GU725933 & Uncultured organism clone MAT-CR-H2-A10 $16 \mathrm{~S}$ ribosomal RNA gene & EU245100 & 88 & 716 & 839 & 1 \\
\hline 162 & GU726030 & Uncultured bacterium clone SGUS1230 16S ribosomal RNA gene & FJ202161 & 92 & 727 & 1035 & 2 \\
\hline 143 & GU726043 & Uncultured bacterium clone PL 212 16S ribosomal RNA gene & FJ268573 & 83 & 565 & 507 & 1 \\
\hline 120 & GU726007 & Uncultured bacterium clone SHFH449 16 S ribosomal RNA gene & FJ203414 & 93 & 752 & 1112 & 3 \\
\hline 012 & GU725821 & Uncultured bacterium clone SHFH449 16 S ribosomal RNA gene & FJ203414 & 93 & 555 & 819 & 2 \\
\hline 244 & GU725854 & Uncultured bacterium clone SHFH449 16 S ribosomal RNA gene & FJ203414 & 93 & 723 & 1053 & 2 \\
\hline
\end{tabular}




\section{REFERENCES}

Altschul, S., Madden, T., Schaffer, A., Zhang, J., Zhang, Z., Miller, W., \& Lipman, D. (1997) Gapped BLAST and PSI-BLAST: a new generation of protein database search programs 10.1093/nar/25.17.3389. Nucl Acids Res 25: 3389-3402.

Behrens, S., Losekann, T., Pett-Ridge, J., Weber, P. K., Ng, W. O., Stevenson, B. S. et al. (2008) Linking microbial phylogeny to metabolic activity at the single-cell level by using enhanced element labeling-catalyzed reporter deposition fluorescence in situ hybridization (EL-FISH) and NanoSIMS. Appl Environ Microbiol 74: 3143.

Buchan, A., Gonzalez, J. M., \& Moran, M. A. (2005) Overview of the marine Roseobacter lineage. Appl Environ Microbiol 71: 5665-5677.

Capone, D. G., Zehr, J. P., Paerl, H. W., Bergman, B., \& Carpenter, E. J. (1997) Trichodesmium, a globally significant marine cyanobacterium. Science 276: 12211229.

Carlson, C. A., Morris, R., Parsons, R., Treusch, A. H., Giovannoni, S. J., \& Vergin, K. (2008) Seasonal dynamics of SAR11 populations in the euphotic and mesopelagic zones of the northwestern Sargasso Sea. ISME J 3: 295.

Carpenter, E. J., Harvey, H. R., Fry, B., \& Capone, D. G. (1997) Biogeochemical tracers of the marine cyanobacterium Trichodesmium. Deep-Sea Res I 44: 27-38.

Carpenter, E.J., Subramaniam, A., \& Capone, D.G. (2004) Biomass and primary productivity of the cyanobacterium Trichodesmium spp. in the tropical N Atlantic ocean. Deep-Sea Res I 51: 173-203.

Chao, A. (1987) Estimating the population size for capture-recapture data with unequal catchability. Biometrics 43: 783-791.

Chao, A., \& Yang, M. C. K. (1993) Stopping rules and estimation for recapture debugging with unequal failure rates. Biometrika 80: 193-201.

Cole, J. R., Chai, B., Marsh, T. L., Farris, R. J., Wang, Q., Kulam, S. A. et al. (2003) The Ribosomal Database Project (RDP-II): previewing a new autoaligner that allows regular updates and the new prokaryotic taxonomy. Nucl Acids Res 31: 442-443.

Dang, H., \& Lovell, C. R. (2000) Bacterial primary colonization and early succession on surfaces in marine waters as determined by amplified rRNA gene restriction analysis and sequence analysis of 16S rRNA genes. Appl Environ Microbiol 66: 467-475. 
Dang, H., Li, T., Chen, M., \& Huang, G. (2008) Cross-ocean distribution of Rhodobacterales bacteria as primary surface colonizers in temperate Coastal Marine Waters. Appl Environ Microbiol 74: 52-60.

Davis, C. S., \& McGillicuddy Jr, D. J. (2006) Transatlantic abundance of the $\mathrm{N}_{2}$-fixing colonial cyanobacterium Trichodesmium . Science 312: 1517.

Davis, J. P., Youssef, N. H., \& Elshahed, M. S. (2009) Assessment of the diversity, abundance, and ecological distribution of members of candidate division SR1 reveals a high level of phylogenetic diversity but limited morphotypic diversity. Appl Environ Microbiol 75: 4139-4148.

Decho, A. W., Visscher, P. T., Ferry, J., Kawaguchi, T., He, L., Przekop, K. M. et al. (2009) Autoinducers extracted from microbial mats reveal a surprising diversity of Nacylhomoserine lactones (AHLs) and abundance changes that may relate to diel $\mathrm{pH}$. Environ Microbiol 11: 409-420.

DeLong, E. F., Franks, D. G., \& Alldredge, A. L. (1993) Phylogenetic diversity of aggregate-attached vs. free-living marine bacterial assemblages. Limnol Oceanogr 924-934.

Dyhrman, S. T., Webb, E. A., Anderson, D. M., Moffett, J. W., \& Waterbury, J. B. (2002) Cell-specific detection of phosphorus stress in Trichodesmium from the western North Atlantic. Limnol Oceanogr 47: 1832-1836.

Fisher, M. M., Wilcox, L. W., \& Graham, L. E. (1998) Molecular characterization of epiphytic bacterial communities on charophycean green algae. Appl Environ Microbiol 64: 4384-4389.

Frigaard, N. U., Martinez, A., Mincer, T. J., \& DeLong, E. F. (2006) Proteorhodopsin lateral gene transfer between marine planktonic Bacteria and Archaea. Nature 439: 847-850.

Good, I. J. (1953) The population frequencies of species and the estimation of population parameters. Biometrika 40: 237-264.

Grossart, H. P., Levold, F., Allgaier, M., Simon, M., \& Brinkhoff, T. (2005) Marine diatom species harbour distinct bacterial communities. Environ Microbiol 7: 860-873.

Harris, J. K., Kelley, S. T., \& Pace, N. R. (2004) New perspective on uncultured bacterial phylogenetic division OP11. Appl Environ Microbiol 70: 845.

Herbst, V., \& Overbeck, J. (1978) Metabolic coupling between the alga Oscillatoria redekei and accompanying bacteria. Naturwissenschaften 65: 598-599. 
Hewson, I., Poretsky, R. S., Dyhrman, S. T., Zielinski, B., White, A. E., Tripp, H. J. et al. (2009) Microbial community gene expression within colonies of the diazotroph, Trichodesmium, from the Southwest Pacific Ocean. ISME J 3: 1286-1300.

Hmelo, L., \& Van Mooy, B. A. S. (2009) Kinetic constraints on acylated homoserine lactone-based quorum sensing in marine environments. Aquat Microb Ecol 54: 127133.

Huber, T., Faulkner, G., \& Hugenholtz, P. (2004) Bellerophon: a program to detect chimeric sequences in multiple sequence alignments. Bioinformatics 20: 2317-2319.

Karl, D., Letelier, R., Tupas, L., Dore, J., Christian, J., \& Hebel, D. (1997) The role of nitrogen fixation in biogeochemical cycling in the subtropical North Pacific Ocean. Nature 388: 533-538.

Karner, M. B., DeLong, E. F., \& Karl, D. M. (2001) Archaeal dominance in the mesopelagic zone of the Pacific Ocean. Nature 409: 507-510.

Letelier, R. M., \& Karl, D. M. (1998) Trichodesmium spp. physiology and nutrient fluxes in the North Pacific subtropical gyre. Aquat Microb Ecol 15: 265-276.

Letelier, R., \& Karl, D. (1996) Role of Trichodesmium spp. in the productivity of the subtropical North Pacific Ocean. MEPS 133: 263-273.

Ludwig, W. (2004) ARB: a software environment for sequence data. Nucl Acids Res 32: 1363-1371.

Marmur, J. (1961) A procedure for the isolation of deoxyribonucleic acid from microorganisms. J Mol Biol 3: 208-218.

Mayali, X., Franks, P. J. S., \& Azam, F. (2008) Cultivation and ecosystem role of a marine Roseobacter clade-affiliated cluster bacterium. Appl Environ Microbiol 74: 2595.

Mohamed, N. M., Enticknap, J. J., Lohr, J. E., McIntosh, S. M., \& Hill, R. T. (2008) Changes in bacterial communities of the marine sponge Mycale laxissima on transfer into aquaculture. Appl Environ Microbiol 74: 1209-1222.

Nausch, M. (1996) Microbial activities on Trichodesmium colonies. Mar Ecol Prog Ser 141: $173-181$.

Nicol, G. W., \& Schleper, C. (2006) Ammonia-oxidising Crenarchaeota: important players in the nitrogen cycle? Trends Microbiol 14: 207-212. 
Paerl, H. W., \& Gallucci, K. K. (1985) Role of chemotaxis in establishing a specific nitrogen-fixing cyanobacterial-bacterial association. Science 227: 647.

Paerl, H. W., Bebout, B. M., \& Prufert, L. E. (1989) Bacterial associations with marine Oscillatoria sp. (Trichodesmium sp.) populations: Ecophysiological implications. $J$ Phycol 25: 773-784.

Paerl, H., \& Pinckney, J. (1996) A mini-review of microbial consortia: their roles in aquatic production and biogeochemical cycling. Microb Ecol 31: 225-247.

Paerl, H. W. (1982) Interactions with bacteria. In The biology of cyanobacteria. University of California Press, pp. 441-461.

Pedrós-Alió, C. (2006) Marine microbial diversity: can it be determined? Trends Microbiol 14: 257-263.

Pommier, T., Canback, B., Riemann, L., Bostrom, K., Simu, K., Lundberg, P. et al. (2007) Global patterns of diversity and community structure in marine bacterioplankton. Mol Ecol 16: 867-880.

Sapp, M., Schwaderer, A. S., Wiltshire, K. H., Hoppe, H. G., Gerdts, G., \& Wichels, A. (2007) Species-specific bacterial communities in the phycosphere of microalgae? Microb Ecol 53: 683-699.

Sheridan, C., Steinberg, D., \& Kling, G. (2002) The microbial and metazoan community associated with colonies of Trichodesmium spp.: a quantitative survey. J Plankton Res 24: 913-922.

Siddiqui, P., Bergman, B., \& Carpenter, E. (1992) Filamentous cyanobacterial associates of the marine planktonic cyanobacterium Trichodesmium. Phycologia 31: 326-337.

Simmons, T. L., Coates, R. C., Clark, B. R., Engene, N., Gonzalez, D., Esquenazi, E. et al. (2008) Biosynthetic origin of natural products isolated from marine microorganism-invertebrate assemblages. PNAS 105: 4587.

Stevenson, B. S., \& Waterbury, J. B. (2006) Isolation and identification of an epibiotic bacterium associated with heterocystous Anabaena cells. Biol Bull 210: 73-77.

Stein, J., Marsh, T., Wu, K., Shizuya, H., \& DeLong, E. (1996) Characterization of uncultivated prokaryotes: isolation and analysis of a 40-kilobase-pair genome fragment from a planktonic marine archaeon. J Bacteriol 178: 591-599. 
Stihl, A., Sommer, U., \& Post, A. F. (2001) Alkaline phosphatase activities among populations of the colony-forming diazotrophic cyanobacterium Trichodesmium spp.(Cyanobacteria) in the Red Sea. J Phycol 37: 310-317.

Sunagawa, S., DeSantis, T. Z., Piceno, Y. M., Brodie, E. L., DeSalvo, M. K., Voolstra, C. R. et al. (2009) Bacterial diversity and White Plague Disease-associated community changes in the Caribbean coral Montastraea faveolata. ISME J 3: 512-521.

Tait, K., Joint, I., Daykin, M., Milton, D. L., Williams, P., \& Camara, M. (2005) Disruption of quorum sensing in seawater abolishes attraction of zoospores of the green alga Ulva to bacterial biofilms. Environ Microbiol 7: 229-240.

Thompson, J. R., Marcelino, L. A., \& Polz, M. F. (2002) Heteroduplexes in mixedtemplate amplifications: formation, consequence and elimination by 'reconditioning PCR'. Nucl Acids Res 30: 2083-2088.

Treusch, A. H., Vergin, K. L., Finlay, L. A., Donatz, M. G., Burton, R. M., Carlson, C. A., \& Giovannoni, S. J. (2009) Seasonality and vertical structure of microbial communities in an ocean gyre. ISME J 3: 1148-1163.

Tuomainen, J., Hietanen, S., Kuparinen, J., Martikainen, P. J., \& Servomaa, K. (2006) Community structure of the bacteria associated with Nodularia sp.(Cyanobacteria) aggregates in the Baltic Sea. Microb Ecol 52: 513-522.

Villareal, T. A., \& Carpenter, E. J. (1990) Diel buoyancy regulation in the marine diazotrophic cyanobacterium Trichodesmium thiebautii. Limnol Oceanogr 1832-1837.

Wagner-Döbler, I., Ballhausen, B., Berger, M., Brinkhoff, T., Buchholz, I., Bunk, B. et al. (2009) The complete genome sequence of the algal symbiont Dinoroseobacter shibae: a hitchhiker's guide to life in the sea. ISME J

Waterbury, J. B. (1991) The cyanobacteria: isolation, purification, and identification. The prokaryotes, 2: 2058-2078.

Yu, Y., Breitbart, M., McNairnie, P., \& Rohwer, F. (2006) FastGroupII: A web-based bioinformatics platform for analyses of large $16 \mathrm{~S}$ rDNA libraries. BMC Bioinformatics 7: 57.

Zehr, J. P. (1995) Nitrogen fixation in the sea: Why only Trichodesmium? In Molecular ecology of aquatic microbes. I. Joint (ed). Springer Verlag, pp. 335-363.

Zinder, D., \& Dworkin, M. (2000) Morphological and physiological diversity. The Prokaryotes 185-220. 


\section{CHAPTER 5:}

\section{BACTERIAL COMMUNICATION REGULATES THE DEGRADATION OF SINKING ORGANIC MATTER IN THE SEA}

The ocean's biological pump is a dynamic and complex system that transports carbon from the atmosphere to the deep ocean. A central component of the biological pump is carbon export via sinking particles composed of photosynthetically derived particulate organic carbon (POC) and biominerals. Bacteria colonize these particles and produce enzymes that dissolve and degrade sinking $\mathrm{POC}^{1}$, thereby acting as one of the major controls on the biological pump ${ }^{2}$. Here we show that bacteria use a cell-cell communication mechanism, quorum sensing (QS), to regulate the activity of organic carbon degrading enzymes on sinking particles. We collected sinking POC from a site of intense primary productivity off Vancouver Island, Canada and found that sinking particles contained acylated homoserine lactones (AHLs), a suite of communication molecules well-known to be produced by bacteria with QS ability ${ }^{3-5}$. In addition, we conducted incubation experiments with the sinking POC and discovered that the addition of exogenous AHLs enhanced the activity of key POC-degrading enzymes to various degrees $^{6,7}$. Our results suggest that AHL-based QS may play an important role in regulating POC degradation in sinking particles and that variability in QS is a heretofore unrecognized process that affects the strength of biological pump.

Sinking POC flux declines significantly in the upper few hundred meters of the ocean $^{8,9}$; only a small percentage $(\sim 10 \%)$ of organic material fixed by photosynthesis is 
transferred to the deep ocean where it is removed from the atmosphere for hundreds to thousands of years. The attenuation of sinking POC flux has been the subject of several major scientific research initiatives over the past three decades. It is generally accepted that organic carbon degradation by POC-attached bacteria contributes significantly to flux-attenuation ${ }^{2}$. However, parameterizing the activity of POC-attached bacteria remains a significant obstacle to the development of accurate carbon cycle models, which are needed to predict future trends in the earth's carbon dioxide budget in response to natural and anthropogenic environmental changes ${ }^{10}$. Currently, flux attenuation is represented by empirical ${ }^{8}$ or chemical models ${ }^{11}$ which do not explicitly incorporate the activities of particle-attached bacteria.

Particle-attached bacterial communities are generally comprised of several bacterial classes, and invariably include significant numbers of Proteobacteria ${ }^{12}$. Many Proteobacteria use QS, mediated by $\mathrm{AHLs}^{13}$, to synchronize gene expression at the high population densities likely to be encountered in sinking POC (up to $10^{9}$ cells $/ \mathrm{mL}$ ) ${ }^{14}$. In pure culture, QS has been shown to be involved in the coordination of genes encoding a number of group-beneficial behaviors (e.g. exoenzyme production and biofilm formation $)^{15}$; the ability to synchronize these behaviors may confer ecological and evolutionary advantages (e.g. nutrient acquisition or collective defense) ${ }^{16}$.

AHLs are rapidly degraded by biological and abiotic mechanisms but remain effective at very low concentrations ${ }^{14,17}$. Direct measurements of AHLs in environmental samples require extremely sensitive and selective analytical tools that are only now 
becoming available to the oceanographic community. Although bacterial isolates from marine particles have been shown to possess the capacity for $\mathrm{QS}^{3}$, in-situ QS activity has yet to be demonstrated in sinking POC.

In order to test the hypothesis that AHL-QS is occurring in marine particles, we collected sinking POC using a sediment net $\operatorname{trap}^{18}$ in Clayoquot Sound on the western coast of Vancouver Island, B.C. in July 2009. We chose Clayoquot Sound because of its high fluxes of marine photosynthetically-derived POC in the summer months (approaching $1 \mathrm{~mol} \mathrm{C}$ per $\mathrm{m}^{2}$ per day, unpublished data, R. Keil). During our sampling, the euphotic zone was observed to extend no deeper than $30 \mathrm{~m}$. Sinking POC was collected by traps suspended at $55 \mathrm{~m}$ and assayed for AHLs by two independent methods. First, POC was applied to agar plates seeded with the AHL-sensing bacterium Agrobacterium tumefaciens NTL4(pZLR4) ${ }^{19}$; the POC induced the distinct response of this biosensor to AHLs (data not shown). This sensitive and robust method clearly indicated that the particles contained chemicals with the bioactivity of AHLs. Second, samples were returned to the laboratory at Woods Hole for chemical analysis by high performance liquid chromatography / electrospray-ionization mass spectrometry (HPLC/ESI-MS). Two AHLs- octanoyl homoserine lactone (C8-HSL) and dodecanoyl homoserine lactone, (C12-HSL)- were structurally identified in the sinking POC on the basis of chromatographic retention time, molecular masses and secondary mass spectra, which were identical to authentic standards (Figure 1). These results confirm that AHLs were present in POC samples and were responsible for the biosensor response. Since AHLs are known to have a rapid turnover time in natural seawater ( 0.5 to 1.5 day $^{-1}$ 
depending on the structure) ${ }^{14}$, the detection of these compounds in our POC samples indicates in-situ activity. AHLs have been directly detected only a handful of times in natural marine environments (e.g. biofilms coating rocks in intertidal pools ${ }^{20}$ and stromatolites ${ }^{21}$ ); this study represents the first time that AHLs have been detected in sinking POC.

Over two decades ago, Smith and Azam ${ }^{22}$ demonstrated that particle-attached bacteria are responsible for intense organic carbon-degrading enzyme activity on sinking POC, which ultimately catalyzes the conversion of sinking POC to suspended POC, dissolved organic carbon (DOC), and ultimately, $\mathrm{CO}_{2}$ via heterotrophic respiration ${ }^{1}$. It has been suggested that coordination of organic carbon degrading enzyme activity is advantageous for POC-attached bacteria ${ }^{23,24}$. Our observation of AHLs in sinking POC supports this suggestion, and during our cruise we conducted incubation experiments to test whether AHL-QS affected rates of organic carbon degradation. We amended incubations containing samples of sinking POC with one of two AHLs- 3-oxo-hexanoyl homoserine lactone (3-oxo-C6-HSL) and 3-oxo-octanoyl homoserine lactone (3-oxo-C8HSL)- at either 500nM or 5000nM. At two time points (6 and 24 hours) we measured the effect of these AHL amendments on protease, lipase, phosphatase, chitinase, and $\alpha$ - and $\beta$-glucosidase activity based upon the methods employed by Smith and Azam. We then compared the incubations amended with AHLs to controls without AHLs and found clear evidence that AHLs enhanced the level of enzyme activity in some instances. 
We observed a strong response to AHL amendments on Day 1 of our sampling program, but samples from Days 2 and 3 displayed diminished responses (corresponding to Traps 1, 2 and 3, respectively). Protease activity was enhanced by more than a factor of two by all AHL treatments in Trap 1, but was enhanced to a lesser extent in Trap 2, and virtually not at all in Trap 3 (Figure 2). Lipase and phosphatase activity were enhanced approximately 3- and 8-fold, respectively, by all AHL treatments in Trap 1 and lipase activity was enhanced by low concentrations of AHL in Trap 3. In comparison, the three glucosidases (chitinase, $\alpha$-glucosidase, and $\beta$-glucosidase) were minimally affected in all three traps (Supp. Fig. 2). Despite the heterogeneity of our samples, these results indicate a biochemical linkage between AHLs and enzyme activity and suggest that the magnitude of this effect may be variable in time and co-regulated by environmental factors, particle properties or microbial flora composition.

The observation that AHLs enhanced the activity of key carbon-degrading enzymes provides strong support for the hypothesis that AHL-based QS regulates sinking POC degradation, and thus POC flux attenuation in the sea. However, an alternative explanation deserves consideration: instead of acting as signalling molecules AHLs could simply have provided carbon and/or nitrogen supplement to particle-attached bacteria and the observed changes in enzyme activity only reflected changes in bacterial nutrition. We discount this latter explanation for the following reasons: First, the amount of carbon we added as AHL was likely to have been 3-4 orders of magnitude lower than the DOC concentration in the interstitial water $(\sim 1$ to $5 \mathrm{mM})$ of typical marine aggregates ${ }^{25}$ and thus it is unlikely that the small amount of AHLs would stimulate such a dramatic 
response. Second, additional AHL in the 5000nM treatments did not systematically enhance the effect induced by the $500 \mathrm{nM}$ treatment; this is suggestive of the threshold response characteristic of QS. In consideration of the preceding arguments, we believe that our first explanation best supports our data: AHL-based QS is a factor in regulating the expression of organic carbon-degrading enzymes.

The occurrence of QS in sinking particles validates theoretical model calculations describing the production of diffusible extracellular enzymes by particle-attached bacteria $^{23}$. Vetter and colleagues ${ }^{23}$ suggested that coordinated action by microbial consortia or clonal populations would maximize the energetic returns on the production of diffusible enzymes to an individual bacterium. Such coordinated behavior is the hallmark of quorum sensing. There are two implications of QS control of hydrolytic enzyme production in sinking particles. First, by attenuating the downward flux of POC, POC-associated bacteria are acting to retain themselves in productive, particle-rich surface waters to which they are adapted. Second, by preferentially stimulating organic $\mathrm{N}$ and P-degrading enzyme activities (protease, lipase, and phosphatase), these same cooperative behaviors may in fact be promoting the retention of major nutrients in surface waters which in turn could support additional primary productivity and bacterial production $^{1}$.

If, as our data suggest, AHL-based QS is a control on organic carbon degradation in sinking particles, then AHL-based QS is likely to be a critical link between atmospheric and oceanic reserves of carbon. Specifically, QS could be a factor in 
determining the remineralization depth of sinking POC. A recent study has shown that modest changes in the remineralization depth can have a major impact on atmospheric carbon dioxide concentrations ${ }^{26}$. We observed that QS can have as much as an 8-fold impact on enzyme hydrolysis rates and we posit that this could in turn result in significant variability on the magnitude of the export flux of sinking POC from the surface ocean and thereby the depth at which it is degraded. If QS has even a 2-fold effect on the hydrolysis of key biochemical fractions (e.g. protein; Fig. 2) of sinking organic matter, then QS could play an important role in regulating of the depth at which POC is remineralized to $\mathrm{CO}_{2}$. A doubling of the hydrolysis rate of proteins $(40 \%$ of labile $\mathrm{POC})^{27}$ would decrease the "e-folding" depth of remineralization by $\approx 30 \mathrm{~m}$ globally whereas a halving of the rate would increase this depth by $\approx 40 \mathrm{~m}$ (Supp. Fig. 3). The efolding depth is defined by convention as the depth at which $63 \%$ of sinking POC is remineralized $^{26}$. Kwon and colleagues calculate a change in e-folding depth as modest as $24 \mathrm{~m}$ can impact $\mathrm{pCO}_{2}$ by $10-27 \mathrm{ppm}^{26}$ which is equivalent to the increase in atmospheric $\mathrm{CO}_{2}$ over the last 5-10 years. Thus, QS has the potential to act as an important buffer of atmospheric $\mathrm{CO}_{2}$.

Future increases in atmospheric $\mathrm{CO}_{2}$ may impact QS because the concomitant decrease in ocean $\mathrm{pH}$ would stabilize AHLs; these molecules are rapidly deactivated by base-catalyzed hydrolysis in the range of $\mathrm{pH} 7-8^{28}$. Remineralization processes within POC cause the $\mathrm{pH}$ to be lower inside the aggregate (as low as $7.2^{30}$ ) with respect to ambient seawater $(\mathrm{pH}=8.2)$. If seawater $\mathrm{pH}$ decreases to 7.7 , as is predicted by the end of this century ${ }^{29}$, the $\mathrm{pH}$ within sinking particles may similarly decline. Lowering the $\mathrm{pH}$ 
within POC aggregates will decrease the rate of base-catalyzed hydrolysis of AHLs, which could in turn impact the regulation of organic-matter degradation. Ocean acidification has been projected to impact numerous marine biological processes, including the calcification of corals and planktonic algae, however, the impact on heterotrophic processes has received little consideration ${ }^{29}$.

QS may serve as a mechanism to translate environmental variability into a biogeochemical response. We suggest that this variability may someday be incorporated into carbon cycle models to capture spatial and temporal variability in POC flux; clearly additional work is required in order to identify the environmental and biological parameters (e.g. particle composition, bacterial community structure) that affected the observed variability in QS-regulated organic matter degradation. Our results show that QS is a heretofore unexplored molecular switch that could play an important role in regulating POC degradation. 


\section{METHODS}

Samples were collected using moored sediment net traps ${ }^{18}$ in Clayoquot Sound $\left(49^{\circ} 9.93 \mathrm{~N}, 125^{\circ} 41.556 \mathrm{~W}\right)$ off the western coast of Vancouver Island at $55 \mathrm{~m}$ depth for 24 hours. Samples were collected at a single site over the course of 4 trap deployments (Traps 1,2, 3, and 4) on separate days in June 2009. Upon trap retrieval, samples were processed immediately. Samples to be applied to an AHL-biosensor were centrifuged for 1 minute at $3000 \mathrm{rpm}$ and applied to agar-plates seeded with the biosensing strain Agrobacterium tumefaciens NTL4(pZLR4) ${ }^{19}$. Samples to be analyzed by mass spectrometry were acidified to $\mathrm{pH} 2$ and frozen at $-20^{\circ} \mathrm{C}$ until transported back to Woods Hole. These particle samples and supernatants were then thawed and separated by centrifugation. Supernatants were extracted in ethyl acetate containing $0.1 \%$ formic acid according to previously published methods ${ }^{14}$. Extracts were analyzed on a Thermo Fisher TSQ triple quadrupole mass spectrometer in selected reaction monitoring mode.

Samples were collected for use in enzyme assays from Traps 1, 2 and 3 and were split into equal 15 ths. Endogenous AHLs were removed from particles by gentle rinsing as follows: each aliquot was centrifuged for one minute at 3000rpm and the supernatant was poured off. Next, $10 \mathrm{~mL} 0.2 \mu \mathrm{m}$ filter-sterilized seawater from $55 \mathrm{~m}$ was reintroduced to the particles. Particles were gently vortexed, centrifuged, and the supernatant was poured off. This procedure was followed one additional time (three washes total). Particles were resuspended by gently vortexing. We amended triplicate tubes with 500nM and 5000nM 3-oxo-C6-HSL and 3-oxo-C8-HSL. In addition, we conducted triplicate control incubations (particles, no-AHL amendment). The incubations were 
sampled at six and twenty-four hour intervals. At each sampling time-point, an aliquot of the incubation was removed and assayed for one of six enzyme activities. Enzyme activities were assayed by observing the hydrolysis product of the commonly used fluorogenic substrates L-leucine-7-amino-4-methylcoumarin (for protease), 4methylumbelliferyl (MUF)-phosphate (for phosphatase), MUF-N-acetyl- $\beta$-Dglucosamine (for chitinase), MUF-butyrate (for lipase), MUF- $\alpha$-glucopyranoside and MUF- $\beta$-glucopyranoside (for $\alpha$ - and $\beta$-glucosidases, respectively) ${ }^{1}$. After substrates were added to aliquots of the incubation, the fluorescence was immediately measured by a CytoFluor Series 4000 multi-well plate reader and again after six and twenty-four hours. An enzyme activity rate was calculated assuming that fluorescence increased linearly with time by applying a calibration to this difference. 
Octanoyl homoserine lactone (C8-HSL)

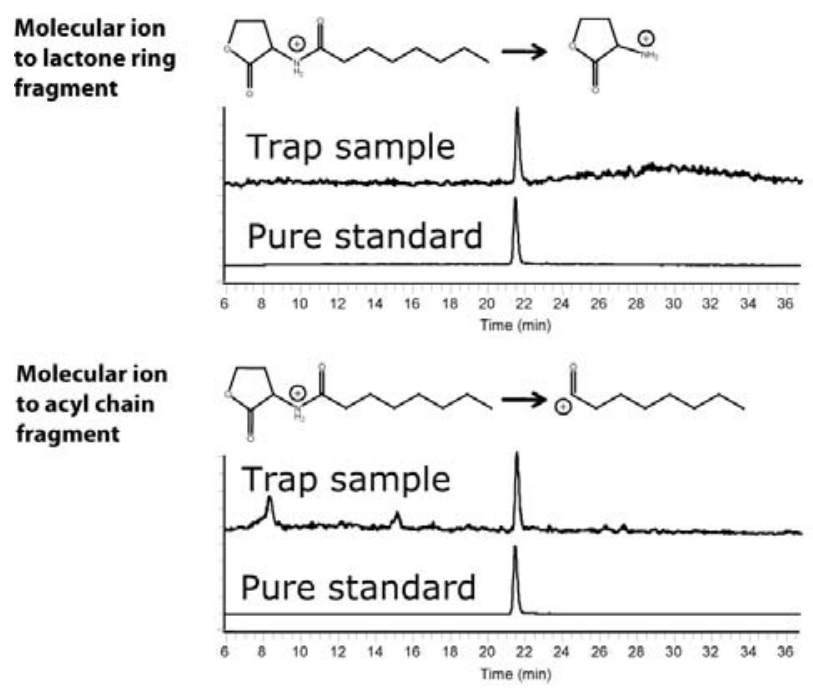

Dodecanoyl homoserine lactone (C12-HSL)
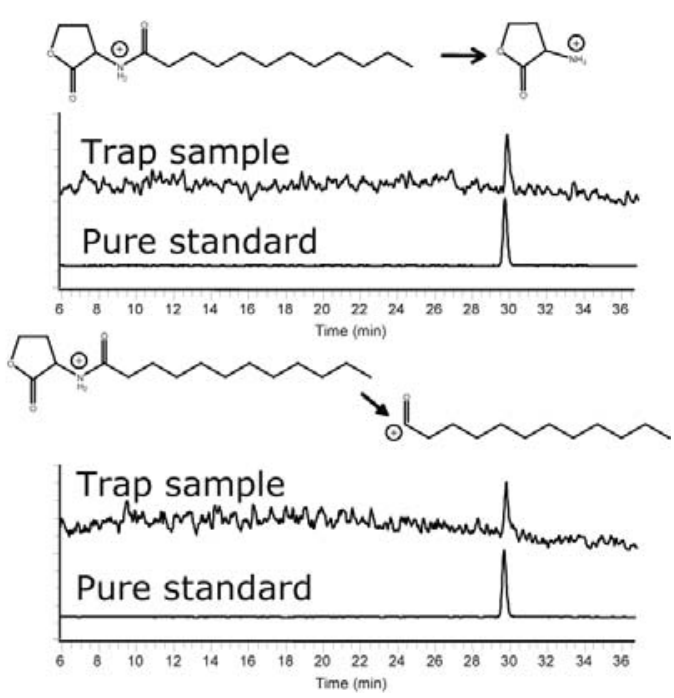

Figure 1: HPLC/ESI-MS data showing the presence of endogenous AHLs present in POC from Trap 4. Each set of traces represents a highly diagnostic fragmentation reaction of a C8-HSL (left quadrants) or C12-HSL (right quadrants) to a lactone ring (upper quadrants) or acyl chain (lower quadrants). In each quadrant, upper traces are from our sinking POC samples and lower traces derive from standards. 
Figure 2. Results of protease (2a), lipase (2b) and phosphatase (2c) assays. Results are presented as ratios of experimental rates relative to unamended-control rates. Error bars are $+/$ - one standard deviation propagated from the error of replicate measurements of treated and control experiments. Daggers $(\dagger)$ indicate $90 \%$ confidence or greater that the ratio is greater than one (i.e. the sample is different from the control). Double daggers $(\$)$ indicate $95 \%$ confidence or greater that the ratio is greater than one. Note, the y-axis scale varies in $2 \mathrm{a}, 2 \mathrm{~b}$, and $2 \mathrm{c}$. 

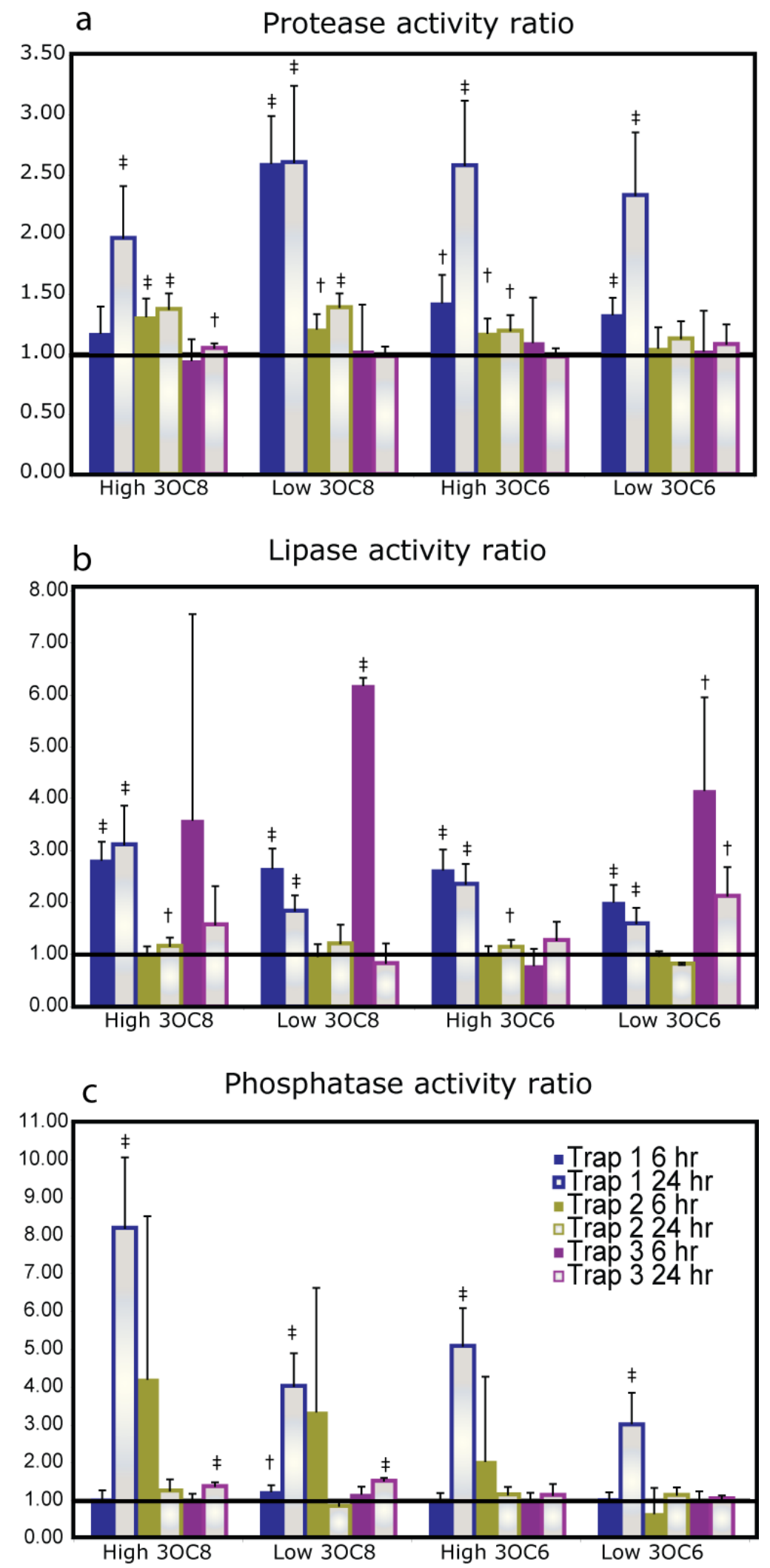
Acknowledgements We thank R. Keil for generously allowing us to use his sediment traps and providing invaluable field support. We also thank K. Buesseler for his valuable comments on an earlier version of this manuscript. We are also grateful to J. Cook for his assistance in preparing our supplementary figures. This work was funded by a grant from the National Science Foundation to B.V.M and T.J.M. (Chemical Oceanography award\# 0825407) 


\section{REFERENCES}

1. Smith, D. C., Simon, M., Alldredge, A. L. \& Azam, F. Intense hydrolytic enzyme activity on marine aggregates and implications for rapid particle dissolution. Nature 359, 139-142 (1992).

2. Steinberg, D. K. et al. Bacterial vs. zooplankton control of sinking particle flux in the ocean's twilight zone. Limnol. Oceanogr. 53, 1327-1338 (2008).

3. Gram, L., Grossart, H., Schlingloff, A. \& Kiorboe, T. Possible quorum sensing in marine snow bacteria: Production of acylated homoserine lactones by Roseobacter strains isolated from marine snow. Appl. Environ. Microb. 68, 4111-4116 (2002).

4. Wagner-Dobler, I. et al. Discovery of complex mixtures of novel long-chain quorum sensing signals in free-living and host-associated marine alphaproteobacteria. Chembiochem 6, 2195-2206 (2005).

5. Eberhard, A. et al. Structural identification of autoinducer of Photobacterium fischeri luciferase. Biochemistry 20, 2444-2449 (1981).

6. Huston, A. L. \& Deming, J. W. Relationships between microbial extracellular enzymatic activity and suspended and sinking particulate organic matter: seasonal transformations in the North Water. Deep-Sea Res. II 49, 5211-5225 (2002).

7. Martinez, J., Smith, D. C., Steward, G. F. \& Azam, F. Variability in ectohydrolytic enzyme activities of pelagic marine bacteria and its significance for substrate processing in the sea. Aquat. Microb. Ecol. 10, 223-230 (1996).

8. Martin, J., Knauer, G., Karl, D. \& Broenkow, W. VERTEX: Carbon cycling in the Northeast Pacific. Deep-Sea Res. 34, 267-285 (1987).

9. Buesseler, K. O. et al. VERTIGO (VERtical Transport In the Global Ocean): A study of particle sources and flux attenuation in the North Pacific. Deep-Sea Res. II 55, 15221539 (2008).

10. Azam, F. Microbial control of oceanic carbon flux: the plot thickens. Science, 694695 (1998).

11. Armstrong, R. A., Lee, C., Hedges, J. I., Honjo, S. \& Wakeham, S. G. A new, mechanistic model for organic carbon fluxes in the ocean based on the quantitative association of POC with ballast minerals. Deep-Sea Res. II 49, 219-236 (2001).

12. Simon, M., Grossart, H. P., Schweitzer, B. \& Ploug, H. Microbial ecology of organic aggregates in aquatic ecosystems. Aquat. Microb. Ecol. 28, 175-211 (2002). 
13. Case, R. J., Labbate, M. \& Kjelleberg, S. AHL-driven quorum-sensing circuits: their frequency and function among the Proteobacteria. ISME J 2, 345 (2008).

14. Hmelo, L. \& Van Mooy, B. A. S. Kinetic constraints on acylated homoserine lactonebased quorum sensing in marine environments. Aquat. Microb. Ecol. 54, 127-133 (2009).

15. Miller, M. B. \& Bassler, B. L. Quorum sensing in bacteria. Annu. Rev. Microbiol. 55, 165-199 (2001).

16. Badri, D. V., Weir, T. L., van der Lelie, D. \& Vivanco, J. M. Rhizosphere chemical dialogues: plant-microbe interactions. Curr. Opin. Biotechnol. 20, 642-650 (2009).

17. Horswill, A. R., Stoodley, P., Stewart, P. S. \& Parsek, M. R. The effect of the chemical, biological, and physical environment on quorum sensing in structured microbial communities. Anal. Bioanal. Chem. 387, 371-380 (2007).

18. Peterson, M. L., Wakeham, S. G., Lee, C., Askea, M. A. \& Miquel, J. C. Novel techniques for collection of sinking particles in the ocean and determining their settling rates. Limnol. Oceanogr. : Methods 3, 520-532 (2005).

19. Farrand, S. K., Qin, Y. \& Oger, P. Quorum-sensing system of Agrobacterium plasmids: Analysis and utility. Method. Enzymol. 358, 452-484 (2002).

20. Tait, K. et al. Turnover of quorum sensing signal molecules modulates cross-kingdom signalling. Environ. Microbiol. 11, 1792-1802 (2009).

21. Decho, A. W. et al. Autoinducers extracted from microbial mats reveal a surprising diversity of $\mathrm{N}$-acylhomoserine lactones (AHLs) and abundance changes that may relate to diel pH. Environ. Microbiol. 11, 409-420 (2009).

22. Smith, D. C., Steward, G. F., Long, R. A. \& Azam, F. Bacterial mediation of carbon fluxes during a diatom bloom in a mesocosm. Deep-Sea Res. II 42, 75-97 (1995).

23. Vetter, Y., Deming, J., Jumars, P. \& Krieger-Brockett, B. A predictive model of bacterial foraging by means of freely released extracellular enzymes. Microb. Ecol. 36, 75-92 (1998).

24. Ziervogel, K. \& Arnosti, C. Polysaccharide hydrolysis in aggregates and free enzyme activity in aggregate-free seawater from the north-eastern Gulf of Mexico. Environ. Microbiol. 10, 289-299 (2008).

25. Alldredge, A. L. Interstitial dissolved organic carbon (DOC) concentrations within sinking marine aggregates and their potential contribution to carbon flux. Limnol.

Oceanogr. 45, 1245-1253 (2000). 
26. Kwon, E. Y., Primeau, F. \& Sarmiento, J. L. The impact of remineralization depth on the air-sea carbon balance. Nat. Geosci. 2, 630-635 (2009).

27. Van Mooy, B. A. S. \& Keil, R. G. Seasonal variation in sedimentary amino acids and the association of organic matter with mineral surfaces in a sandy eelgrass meadow. Mar. Ecol. Prog. Ser. 227, 275-280 (2002).

28. Yates, E. A. et al. N-Acylhomoserine lactones undergo lactonolysis in a pH-, temperature-, and acyl chain length-dependent manner during growth of Yersinia pseudotuberculosis and Pseudomonas aeruginosa. Infect. Immun. 70, 5635-5646 (2002).

29. Doney, S. C., Fabry, V. J., Feely, R. A. \& Kleypas, J. A. Ocean Acidification: The Other CO2 Problem. Annual Review of Marine Science 1, 169-192 (2009).

30. Alldredge, A. L. \& Cohen, Y. Can microscale chemical patches persist in the sea? Microelectrode study of marine snow, fecal pellets. Science 235, 689 (1987). 
Supplemental Figure 1: (Top panel:) Conceptual illustration of QS activity within sinking POC. 1. Bacteria colonize freshly formed sinking POC. 2. Bacteria produce QS signals at a basal rate while they proliferate and clonal populations grow. 3. A particular QS-signal concentration threshold signifies to bacteria that a threshold population has been reached. 4. At this population threshold, bacteria initiate a coordinated expression of hydrolytic enzymes. 5. The production of hydrolytic enzymes leads to the dissolution of sinking POC into smaller suspended POC, DOC, or dissolved $\mathrm{CO}_{2}$.

(Bottom panel:) Conceptual illustration of the potential impact of QS on the flux of sinking POC into the deep ocean. (a) Non-QS scenario where environmental conditions, particle composition, or microbial flora do not support activation of QSregulated genes (e.g. those for the production of organic-matter degrading enzymes). Enzymes are produced only at a low level and POC is able to sink deep into the water column before it is degraded. (b) QS-scenario where environmental conditions, particle composition, or microbial flora do support QS activity and genes responsible for the synthesis of organic-matter degrading enzymes are activated (up-regulated). QSregulated enzyme activity catalyzes the degradation of sinking POC to suspended POC, $\mathrm{DOC}$, or $\mathrm{CO}_{2}$ at shallower depths where they may be more rapidly mixed up into contact with surface water by physical mixing. 


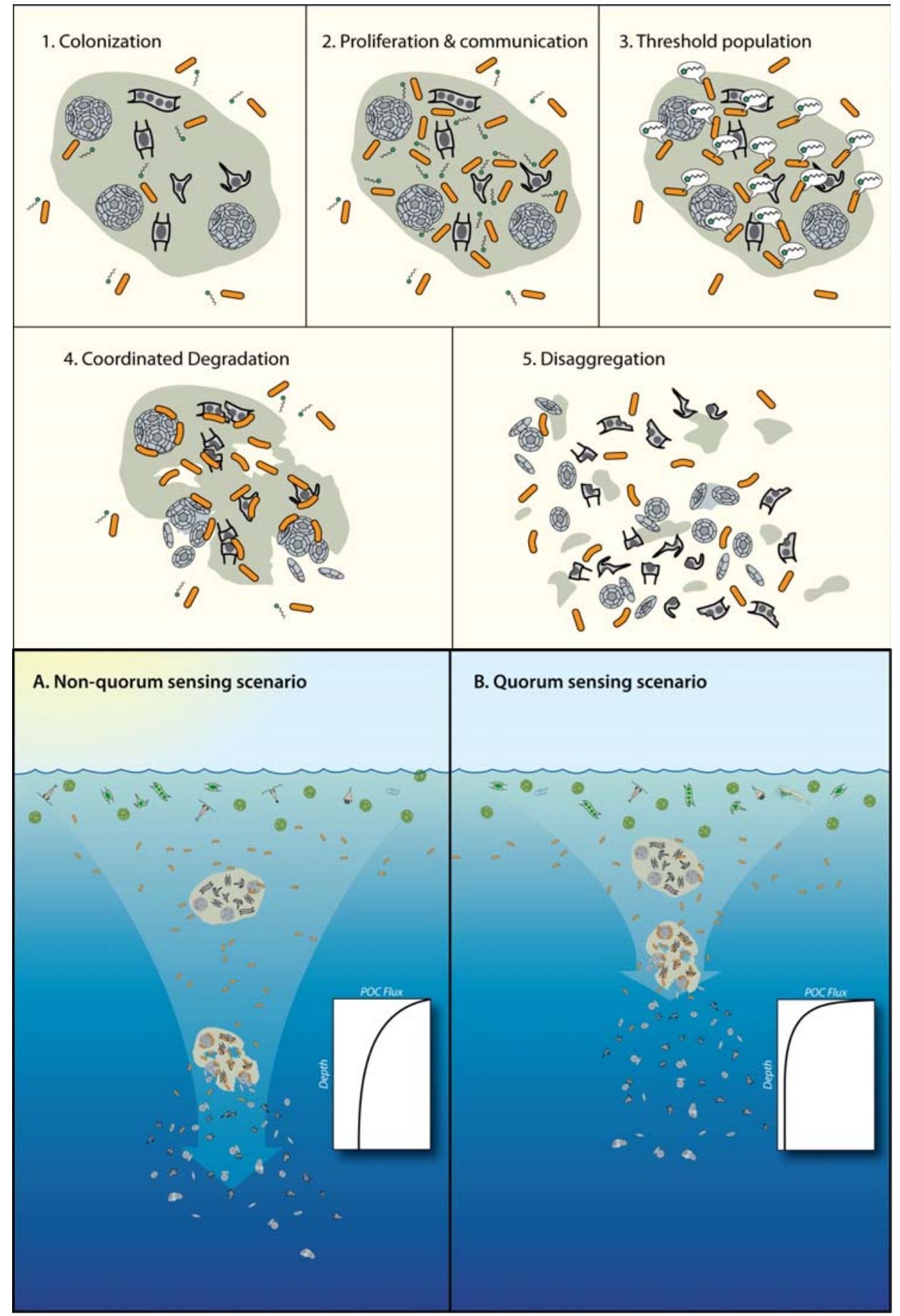


Supplemental Figure 2: Results of $\alpha$ - and $\beta$-glucosidase activity assays. Results are presented as ratios of experimental rates to unamended-control rates. Error bars are +/one standard deviation propagated from the error of replicate measurements of treated and control experiments. Daggers $(\dagger)$ indicate $90 \%$ confidence or greater that the ratio is greater than one (i.e. the sample is different from the control). Double daggers $(\ddagger)$ indicate $95 \%$ confidence or greater that the ratio is greater than one. Asterisks indicate $90 \%$ or greater confidence that ratios are less than one which may indicate that chitinase activity was repressed by the AHL additions. Interestingly, a recent report indicates that chitinase activity in Vibrio harveyi, a common marine Vibrio species, is repressed when its QS genes are activated ${ }^{1}$. Note, the $y$-axis scale varies in $a, b$, and $c$. 

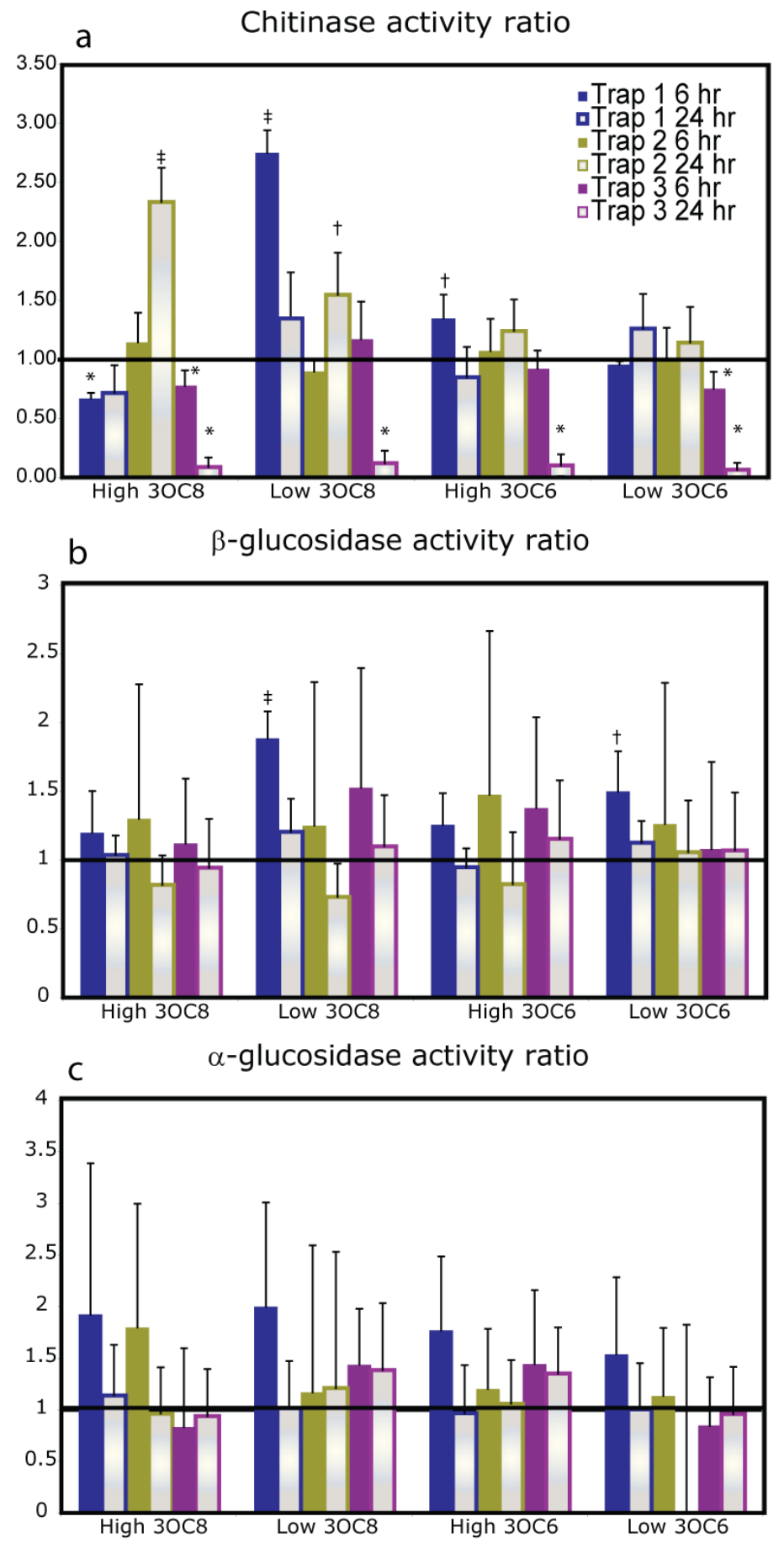
Supplemental Figure 3: POC flux versus depth for three scenarios. Each line is a solution to the equation:

$$
\text { POC }_{\text {total }}=\text { POC }_{\text {Protein }} \mathrm{e}^{-\mathrm{k}_{\text {protien }}{ }^{\mathrm{t}}}+\text { POC }_{\text {Non-protein }} \mathrm{e}^{-\mathrm{k}_{\text {non-protein }}{ }^{\mathrm{t}}}
$$

for 6 days where $\mathrm{POC}_{\text {Protein }}$ is the fraction of total sinking POC flux consisting of proteinacous organic matter at $100 \mathrm{~m}(0.4), \mathrm{POC}_{\text {Non-protein }}$ is the fraction of total sinking POC flux composed of non-proteinacous organic material at $100 \mathrm{~m}(0.6), \mathrm{POC}_{\text {total }}$ is the flux at time ' $\mathrm{t}$ ' (in days), and ' $\mathrm{k}$ ' is the degradation rate $\left(\right.$ day $\left.^{-1}\right)$. Time is calculated as: $\mathrm{t}=$ depth $(\mathrm{m}) /$ sinking rate

where the sinking rate is approximated as $100 \mathrm{~m} \mathrm{day}^{-1}$. In each curve, the concentration of non-proteinaceous material is calculated with a degradation rate ( $\left.\mathrm{k}_{\text {non-prot }}\right)$ of 0.8 day $^{-1}$. The degradation rate of protein $\left(\mathrm{k}_{\mathrm{prot}}\right)$ varies in the three curves as either, 1.6 day $^{-1}, 0.8$ day $^{-1}$, or 0.4 day $^{-1}$. The rate of 0.8 day $^{-1}$ is a reference rate obtained from Van Mooy et al. $(2002)^{2}, 0.4$ day $^{-1}$ represents a scenario where the reference value is halved by a cessation of QS and 1.6 day $^{-1}$ represents a scenario in which the degradation rate is doubled by activation of QS genes. A thick black vertical line is drawn where $63 \%$ of $\mathrm{POC}_{\text {total }}$ has been degraded (the 'e-folding' reference depth; conceptually defined as the sinking rate of $\mathrm{POC}$ divided by the degradation rate). This calculation demonstrates that varying the degradation rate of $40 \%$ of POC by a factor of 2 can impact the e-folding depth by shoaling it $30 \mathrm{~m}$ or deepening it $40 \mathrm{~m}$.

If we can solve these equations for specific depths, then we can assess flux attenuation by fitting a Martin curve ${ }^{3}$ :

$$
\mathrm{F} / \mathrm{F}_{100}=\mathrm{z} / \mathrm{z}_{100}{ }^{-\mathrm{b}}
$$

where $\mathrm{F}$ is POC flux, $\mathrm{F}_{100}$ is flux at $100 \mathrm{~m}, \mathrm{z}$ is depth, $\mathrm{z}_{100}$ is depth at $100 \mathrm{~m}$, and $\mathrm{b}$ is a flux attenuation coefficient, we determine that varying the protein degradation rate from .4 day $^{-1}, 0.8$ day $^{-1}$ or 1.6 day $^{-1}$. 0.8 day $^{-1}$ is reflected in an increase of the $b$ value from 1.17 , to 1.48 , to 1.75 , indicative of more rapid flux attenuation (calculation not shown). 


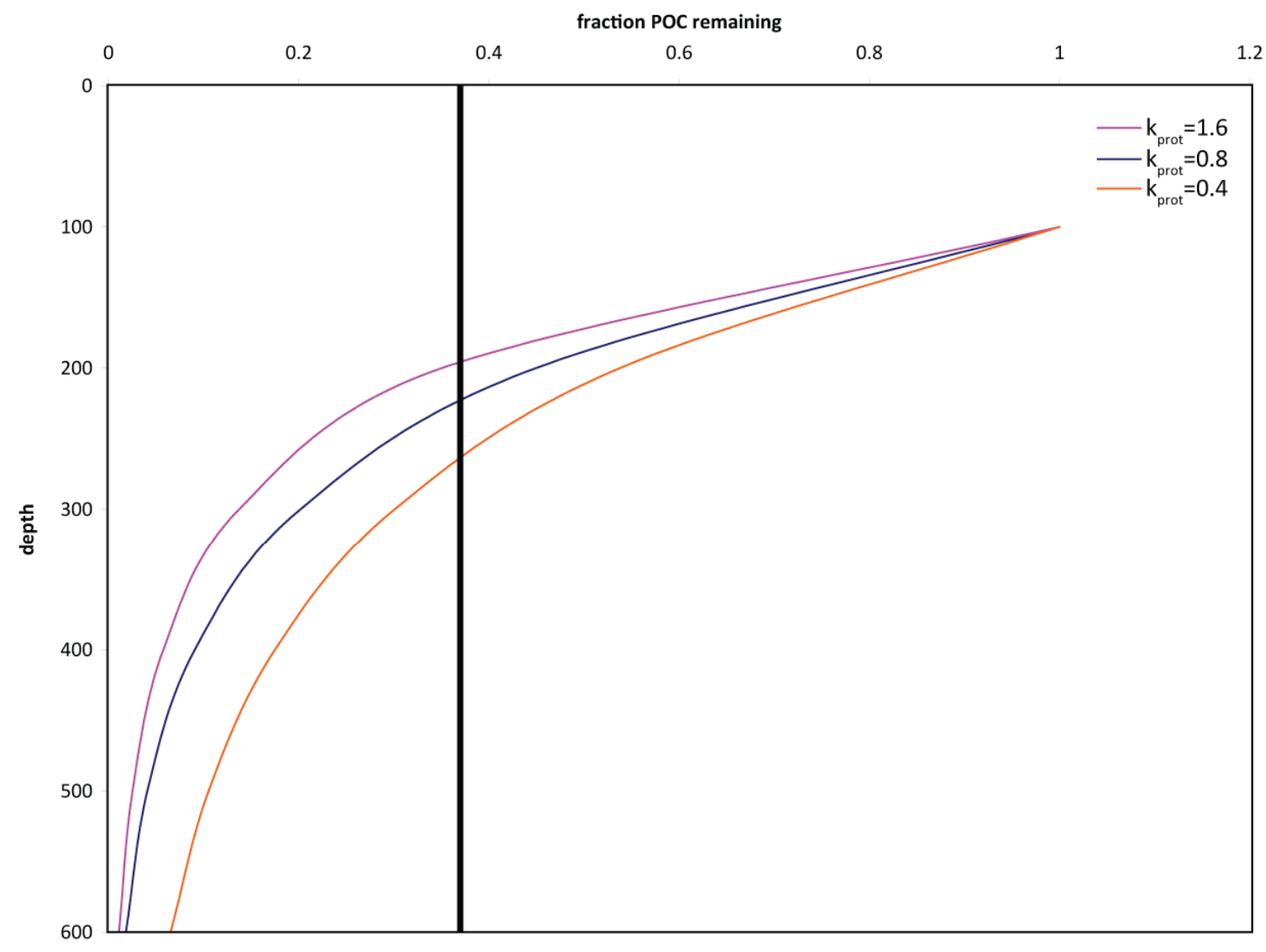




\section{Supplemental References}

1. Defoirdt, T., Ruwandeepika, H. A. D., Karunasagar, I., Boon, N. \& Bossier, P. Quorum sensing negatively regulates chitinase in Vibrio harveyi. Environ. Microbiol. Reports 2, 44-49 (2010).

2. Van Mooy, B. A. S., Keil, R. G. \& Devol, A. H. Impact of suboxia on sinking particulate organic carbon: Enhanced carbon flux and preferential degradation of amino acids via denitrification. Geochim. Cosmochim. Acta 66, 457-465 (2002).

3. Martin, J., Knauer, G., Karl, D. \& Broenkow, W. VERTEX: Carbon cycling in the Northeast Pacific. Deep-Sea Res. 34, 267-285 (1987). 


\section{CHAPTER 6:}

\section{CONCLUSIONS}

To varying degrees, bacteria are social organisms that exhibit deliberate and calculated behaviors. They are capable of adjusting and transforming their behavior depending on their neighbors, their mode of existence (attached to a surface or freeliving), or their available food substrates. The manner in which bacteria in the ocean interact has profound implications for ecological processes and biogeochemical transformations within the ocean. Through their associations with phytoplankton and detrital carbon, bacteria play an important role in the lifecycle of algal blooms and the variability in the strength of the biological pump.

Although bacteria have been studied for over three hundred years, it was not until thirty years ago that two very remarkable ideas were presented. In 1974, Pomeroy proposed the concept of 'the Microbial Loop' and implicated bacteria as major conduits of carbon and energy in the ocean (Pomeroy, 1974). Around the same time, independent of the latter idea, the concept was introduced that bacterial cells might not be as independent as previous thought but in fact they interact with one another through the production of specific chemicals (Tomasz, 1965; Nealson et al., 1970). Even more recently, it was proposed that specific interactions between bacteria in the microbial loop could shape the biogeochemistry of the ocean (Azam et al., 1994). This Ph.D. dissertation is deeply rooted in these ideas and aimed to deepen our knowledge and understanding of 
bacterial interactions in the ocean by elucidating some of the specific bacterial interactions which impact the ocean's carbon cycle.

In this thesis, I examined two types of bacterial interactions, the cell-to-cell communication mechanism dubbed "quorum sensing" and the implied mechanism which structures the unique epibiont community associated with Trichodesmium spp. I observed that bacteria actively partner with other bacteria taxa. Whether Trichodesmium actively or passively recruits the bacteria with which it exists in a consortial relationship, they are not randomly selected from the abundant members of the pelagic seawater community. In fact, I detected bacteria which have never been observed before. While the metabolic capacity of these bacteria remains unknown, it is likely that they are fulfilling specialized roles in the unique environment of the Trichodesmium consortia. Remarkably, these bacteria, which are rare within the pelagic bacterial community, find their way to specific hosts and partnerships.

I observed that bacteria associated with Trichodesmium are capable of both quorum sensing (QS) and bioluminescence, a biochemical behavior mediated by QS. Bioluminescence, while regulated by bacterial communication, is in turn thought to play a role in communication with higher organisms. With respect to bacterial bioluminescence, it is thought to assist in dispersion and propagation of bacterial cells through ingestion and egestion from zooplankton. Further, I was able to manipulate the bacteria associated with Trichodesmium by providing them with exogenous QS signals and thereby induce them to produce additional enzyme activity. 
I similarly manipulated the bacterial communities which associate with particulate organic carbon, one of the main vehicles for carbon flux into the deep sea. The success of this approach suggests that particle-attached bacteria of numerous varieties are sensitive to QS signals and are by implication, social organisms.

The results of this thesis are consistent with the ideas set forth in the first paragraph of this chapter; I showed that bacteria associated with Trichodesmium colonies and photosynthetically derived detritus responded to signals (AHLs) which mediate social behavior and that these AHLs impacted phenotypes which are involved in accessing nutrients bound within photosynthetically derived particles. I observed variability of the response of these communities to QS signals. Although I can only speculate as to the environmental factors co-regulating their effectiveness, it is evident that QS may be one mechanism which can translate environmental variability into a biogeochemical response.

In 1994, Farooq Azam and his colleagues wrote: “...a fundamental challenge for [oceanographers in] the future is to understand the ecological interactions among the members of the microbial loop, because such interactions form the bases of the biogeochemical fluxes." As I discussed in Chapter 5, parameterizing the interactions and behavior of bacteria is necessary in order to develop accurate carbon cycle models which are needed to predict future trends in earth's carbon dioxide budget in response to natural and anthropogenic environmental changes. In this thesis, I have contributed to our knowledge of microbial interactions in the ocean and laid groundwork for future investigations into the unexplored aspects of microbial interactions, in general, and QS, 
in particular, on the ocean's biogeochemical cycles and the variability inherent within them. 


\section{REFERENCES}

Azam, F., Smith, D. C., Steward, G. F., \& Hagström, Å. (1994) Bacteria-organic matter coupling and its significance for oceanic carbon cycling. Microb Ecol 28: 167-179.

Nealson, K. H., Platt, T., \& Hastings, J. W. (1970) Cellular control of the synthesis and activity of the bacterial luminescent system. J Bacteriol 104: 313-322.

Pomeroy, L. R. (1974) The ocean's food web, a changing paradigm. Bioscience 24: 499.

Tomasz, A. (1965) Control of the competent state in Pneumococcus by a hormone-like cell product: an example for a new type of regulatory mechanism in bacteria. Nature 208: $155-159$. 


\section{APPENDIX I:}

INTER-COMPARISON OF EPIBIONT COMMUNITIES ASSOCIATED WITH LABORATORY-CULTIVATED TRICHODESMIUM OBTAINED FROM THE CULTURE COLLECTION AT

\section{THE WOODS HOLE OCEANOGRAPHIC INSTITUTION}

\section{INTRODUCTION}

Trichodesmium spp. are of widespread scientific interest because they are significant players in both the marine carbon cycle as well as the nitrogen cycle (see introduction to Chapter 4). Extensive effort has been devoted to isolating individual strains of these organisms and cultivating them in the laboratory for detailed physiological and ecological studies (Waterbury, 1991). While studies of isolated Trichodesmium spp. are certainly valuable, their associated heterotrophic epibionts are rarely considered in parallel. Trichodesmium spp. are notoriously difficult to cultivate axenically. $T$. erythraeum strain IMS101 has been successfully cultivated in axenic culture, however, this strain does not currently exist in axenic culture (J. Waterbury, personal communication). The identities of the epibionts which now associate with T. erythraeum strain IMS101, as well as the identity of epibionts on strains which have never been axenic, are currently unknown.

It is well known that bacteria in laboratories can exhibit different traits than their relatives in the 'wild' (Palková, 2004). In addition, it is also demonstrated that 
members of biofilms can change over time under laboratory conditions. Considering that these epibionts are essential members of Trichodesmium consortia, they likely contribute to some of the physiological traits exhibited by 'Trichodesmium' in the lab; it is therefore important to deduce the identities of these epibionts. As a complement to a field study of the epibiotic bacteria associated with Trichodesmium (Chapters 3 and 4), we examined the epibionts associated with three laboratory-cultivated strains of Trichodesmium by cultivation dependent and independent approaches. There were two specific aims associated with this study. First, we wished to examine whether or not the epibionts associated with laboratory strains of Trichodesmium are similar to those associated with field populations. Second, we were interested to determine whether or not the bacteria that had 'contaminated' the once-axenic T. erythraeum strain IMS101 are similar to or different from those present on other strains of Trichodesmium housed within the same culture collection.

\section{METHODS}

\section{Origin of sample strains}

Trichodesmium spp. were obtained from the Woods Hole Oceanographic Institution culture collection. Trichodesmium erythraeum strain K-11\#131 was originally isolated from the S. Pacific $\left(27^{\circ} 41^{\prime} \mathrm{S} 162^{\circ} 02^{\prime} \mathrm{E}\right)$ in 2007 (J.B. Waterbury). T. thiebautii strain H94A was originally isolated from the N. Pacific, Station ALOHA $\left(22^{\circ} 45^{\prime} \mathrm{N} 158^{\circ} 00^{\prime} \mathrm{W}\right)$ in 2000 (J.B. Waterbury). T. erythraeum strain IMS101 was isolated from the Gulf Stream off of the N. Carolina Coast in 1992 (Prufert-Bebout, 1993). 


\section{DNA extraction and subsequent processing}

DNA was extracted, amplified, cloned and sequenced in the same manner as described in Chapter 4 for PT and TT clone libraries. Biomass extracted for DNA was extracted from $40 \mathrm{~mL}$ aliquots of 18 day old cultures of T. erythraeum strains K-11\#131 and IMS101 and T. thiebautii strain H9-4A by gentle filtration onto $5 \mu \mathrm{m}$ polycarbonate filters.

\section{RESULTS}

A note on nomenclature: Trichodesmium strains utilized in this study will be here forth referred to only by their strain designations (e.g. IMS101, K-11\#131, or H9-4A).

After chimeric sequences were removed from the clone library datasets, 91, 108, and 116 high-quality sequences remained in K-11\#131, H9-4A, and IMS101 clone libraries, respectively (Table 1). According to Good's coverage calculation, this corresponds to $86 \%, 83 \%$, and $95 \%$ coverage, respectively. This result is mirrored in rarefaction curves (Figure 1) which indicate that our datasets approached rarefaction and are likely to generate a reliable profile of the microbial community on each of these Trichodesmium strains. As a result of obtaining coverage of less than $100 \%$, the observed richness in our communities is less than that predicted by the Chaol estimated richness index. We observed 16, 20, and 12 OTUs at the 97 percent sequence identity (PSI) threshold for K11\#131, H9-4A, and IMS101, respectively (Table 1). This is in contrast to 66, 50, and 25 which are predicted to be the actual richness present in these communities. Despite the 
greater predicted richness in $\mathrm{H} 9-4 \mathrm{~A}, \mathrm{~K}-11 \# 131$ is associated with a more diverse epibiotic community (as indicated by the Shannon-Wiener index; Table 1). As indicated, these results are strongly dependent on our choice of the 97 PSI threshold; evaluating our clone libraries at 99 or 100 PSI would lead to higher OTUs, richness and diversity indices (Table 1).

\section{Archaea and Eukarya}

No archaeal or eukaryotic $16 \mathrm{~S}$ or $18 \mathrm{~S}$ small subunit ribosomal DNA was amplified employing conserved primers in the PCR with DNA templates derived from either K-

11\#131, H9-4A or IMS101 community. DNA from a fosmid template clone 4B7 (Group I Crenarchaea) (Stein et al., 1996) and a eukaryotic enrichment produced from seawater collected during HOTS cruise 179 (http://hahana.soest.hawaii.edu/hot/hot jgofs.html) at Station ALOHA at $25 \mathrm{~m}$ were used as positive amplification controls, respectively; all positive controls amplified.

\section{Epibiotic bacteria identified within clone libraries}

All of the heterotrophic members of the clone libraries were binned at 97 PSI and assigned to a taxonomic group at a class level (Figure 2). The H9-4A epibiont community is composed of 50\% Gammaproteobacteria, 27\% Alphaproteobacterial, and $1 \%$ Deltaproteobacteria. The remaining $22 \%$ are composed about $13 \%, 4 \%$, and $4 \%$ Planctomycetes, Sphingobacteria and Flavobacteria, respectively. At a class level, IMS101 is composed of 41\% Alphaproteobacteria, 21\% Gammaproteobacteria, and 12\% 
and 26\% Flavobacteria and Sphingobacteria. K-11\#131 is 59\% Gammaproteobacteria, 24\% Alphaproteobacteria, 12\% and 5\% Flavobacteria and Sphingobacteria.

The Gammaproteobacteria associated with K-11\#131 and IMS101 are exclusively associated with the order Alteromonadales. All but six of the K-11\#131 Alteromonadales can be assigned with high confidence (greater than $80 \%$ bootstrap value according the the RDP II automatic classifier) to the genus Alteromonas. All of the IMS101 Alteromondales can be assigned to Alteromonas with high confidence. On the other hand, the single clone which clusters near the Alteromonadales in the H9-4A library only does so with $50 \%$ confidence. In fact, $95 \%$ (21 of 22 ) of the gammaproteobacterial clones associated with H9-4A are related to the order Thiotrichales with high confidence. Of those, all but one are members of the genus Methylophaga. The similarity between the K-11\#131 and IMS101 clone libraries, as well as the contrast between these two libraries and H9-4A is evident when the sequences are viewed in a phylogenetic tree (Figure 4).

The Alphaproteobacteria associated with K-11\#131 cluster near the order Rhizobiales with low bootstrap confidence (individual sequences $\sim 40-45 \%$ ). Indeed, these sequences (K-11\#131_097, 098, 102, 092, 087, 093, 094, 099, 086, 088, 089, 090, 091, and 100) group together in a phylogenetic tree with long branch lengths separating them from their nearest neighbors (Figure 3). On the other hand, all but five of the Alphaproteobacteria associated with H9-4A are very strongly associated with the Rhodobacterales and can in fact be assigned to the family Rhodobacteraceae with greater than $80 \%$ confidence. Nine of the IMS101 clones can be assigned to the Rhodobacterales 
(and Rhodobacteraceae) with greater than $80 \%$ confidence and a single clone can be assigned to the Caulobacterales with $100 \%$ confidence (genus Maricaulis, $100 \%$ confidence). Four clones within the IMS101 library are distantly related to the Rhodobacterales (IMS101_054, 092, 039, and 064) and cluster together with the five H94A clones which did not cluster strongly with the Rhodobacterales (H9-4A_112, 071, 051, 082, and 012; Figure 3).

None of the members of the Bacteroidetes (Flavobacteriales and Sphingobacterales) within the K-11\#131 could be assigned to a family with greater than $80 \%$ confidence. In fact, only the sequences labeled in Figure 2 as "Flavobacteriales" could be assigned to the Bacteroidetes with such confidence. In may be more appropriate to consider the K-11\#131 clone sequences provisionally assigned to Flavobacteriales and Sphingobacterales in Figure 2 and represented in Figure 5 as "unclassified bacteria". In contrast, the Bacteroidetes in the IMS101 and H9-4A clone libraries can be confidently assigned to taxa down to the family level. The two H9-4A Sphingobacterales sequences can be further assigned to the family Flammeovirgaceae as can one clone within the IMS101 library. IMS101 contains four additional Sphingobacterales clones which can be confidently categorized as members of the family Chitinophageaceae. Both Flavobacteriales clone in the H9-4A library can be further categorized as Flavobacteraceae as can the four IMS101 Flavobacteriales clones.

The H9-4A epibionts classified as Planctomycetes (six clones) and Deltaproteobacteria (one clone) in Figure 2 are classified with low bootstrap confidence. While the deltaproteobacterial clone is similar (at 99 PSI) to other sequences in GenBank, 
the planctomycetes share only 85 PSI with their nearest relatives. The deltaproteobacterial clone shows high similarity with a clone derived from the burrow wall of a polychaete worm (accession number FJ752802) as well as an isolate of a marine sponge (accession number EU346460)

\section{Epibiotic bacteria cultivated from Trichodesmium}

In total, thirty-five bacteria were isolated from laboratory cultivated Trichodesmium. Seventeen cultivars are derived from IMS101 and ten and eight are derived from K11\#131 and H9-4A, respectively. Twenty-four of the cultivars are members of the Gammaproteobacteria, ten are members of the Alphaproteobacteria, and one is a member of the Bacteroidetes.

All of the alphaproteobacterial cultivars were isolated from IMS101. Six of the ten are of the genus Erythrobacter and four are members of Maricaulis. Classifaction of the gammaproteobacterial isolates is less straightforward. All but one of the H9-4A cultivars (A001, A004, A594, A005, A006, A002 and A003) share only 86-88 PSI with their nearest relative in GenBank. When these cultivars are placed in a phylogentic tree with other sequences from this study as well as their nearest relatives in GenBank, they stand out quite dramatically as a cluster with a long branch length (Figure 3). Several

cultivars from IMS101 also fall within this cluster (A017, A607, A603, A605, A606 and A608). None of the cultivars from K-11\#131 are phylogenetically similar to this cluster. All of the gammaproteobacterial cultivars isolated from K-11\#131 are members of the 
Alteromonas. One additional cultivar was isolated from H9-4A and is a member of the Methylophaga.

The one Bacteroidetes isolate was cultivated from IMS101 and is a member of the Flavobacteriales. In contrast to the isolates retrieved from field strains of Trichodesmium (Chapter 3), no Actinobacteria were isolated.

\section{Representation of cultivated strains within clone libraries}

In contrast to the results of our field sampling study (Chapters 3 and 4) in which no cultivars were similar to 97 PSI OTUs represented in clone libraries generated from samples at the same site, in this study, we see some overlap between 16S rRNA gene sequences extracted from cultivars and represented in clone libraries derived from the same cultured strains of Trichodesmium as is evident in Figures 3, 4, and 5. For example, cultivar A593_H9-4A clusters very tightly with Methylophaga clones retrieved from the H9-4A clone library. Similarly, A604_K-11\#131, A599_K-11\#131 and A595_K-11\#131 cluster tightly with Alteromonas clones retrieved from K-11\#131 and IMS101 clone libraries. Members of the genus Maricaulis are represented in the clone library and cultivars of IMS101. Interestingly, two isolates derived from Trichodesmium collected at the BATS site (A484_BATS and A485_BATS; Chapter 3) cluster tightly with the Alteromonas isolates and clones from K-11\#131 and IMS101 although no Alteromonas were present in either clone library derived from samples collected at BATS. 


\section{DISCUSSION}

Epibiotic bacteria associated with Trichodesmium are postulated to exist in a mutualistic or even symbiotic association in which bacteria might detoxify waste products of Trichodesmium (Paerl \& Millie, 1996) or contribute essential growth factors (Paerl \& Millie, 1996). Many eukaryotic algae have external vitamin requirements, for example, many require an exogenous source of vitamin B12 (Croft et al., 2005). Croft et al. (2005) specifically addressed the B12 requirements of eukaryotic algae, they detected a B12 requirement in eight different algal phyla, and 171 species overall, suggesting that a common role of epiphytic bacteria is the supply of this vitamin. Much less work has been done to address the vitamin B12 requirements of cyanobacteria, but there is limited evidence to suggest that several genera of cyanobacteria do require exogenous sources of this vitamin (Pintner \& Provasoli, 1958; Baalen, 1961; Burkholder, 1963). While the genetic pathway for B12 synthesis appears to be intact in the genome of T. erythraeum strain IMS101, little is known about B12 requirements of other Trichodesmium spp. (T. mincer, personal communication). The goal here is not to argue that the epibionts associated with Trichodesmium are supplying vitamin B12 in particular, but to argue that there is ample precedent for the supply of essential growth factors by epibionts to their algal host. No work has been done addressing the exchange of specific metabolites between Trichodesmium and its associated epibionts, but it is likely that they do supply Trichodesmium with essential growth factors. In addition to possibly supplying metabolites to Trichodesmium, attached-bacteria may play a role in iron acquisition (Barbeau et al., 2010) or the maintenance of an appropriate redox environment for 
Trichodesmium (Paerl et al., 1989). Differences in the community structure should be expected to affect the physiological state and ecological function of the Trichodesmium colony.

It is evident from a cursory examination of Figures 3, 4, and 5, that K-11\#131 and H9-4A host entirely different microbial populations. In fact, there exist no overlapping OTUs at the 97 PSI threshold. This is perhaps not unexpected; K-11\#131 and H9-4A are different species of Trichodesmium and they were isolated from different parts of the Pacific Ocean during different years. What is unexpected is that IMS101, which is the same species as K-11\#131 but was isolated from a separate ocean basin, would share many of the same 97 PSI OTUs with both K-11\#131 and H9-4A. As discussed earlier, IMS101 was formerly axenic and housed within the same culture collections as K11\#131 and H9-4A. It is therefore likely that the 'contaminating' heterotrophs derive not only from K-11\#131 and H9-4A, but others within the collection. It would be interesting to compare the epibionts associated with the model organisms, IMS101, from several laboratories in which it is studied. We hypothesize that they will exhibit different epibiont profiles which will reflect the other strains in the same culture collection.

In Chapter 4 of this thesis, two additional clone libraries, derived from aggregated field populations of $T$. thiebautii are described. A broad comparison between these field samples and H9-4A is interesting, especially since the cyanobacteria associated with the PT library are exclusively T. thiebautii. $95 \%$ of the gammaproteobacterial clones associated with H9-4A are categorized by RDP II as members of the Thiotrichales with very high confidence. Interestingly, the gammaproteobacterial clones associated with the 
PT-library also cluster nearest to Thiotrichales, albeit with very low bootstrap confidence. $66 \%$ of the PT Alphaproteobacteria are members of the Rhodobacterales while $100 \%$ of H9-4A Alphaproteobacteria cluster with the Rhodobacterales. Both libraries contain member of the Flavobacteriales (further classified as Flavobacteraceae). Some major differences do exist; The PT library contains members of the Chloroflexi and Verrucomicrobia and contains no Planctomyces, which are present in the H9-4A library. In addition, even the Thiotrichales-like clones, Rhodobacterales clones, and Flavobacteriales clones differ between the two libraries at finer taxonomic designations. These differences may be important when and if results of studies of $\mathrm{H} 9-4 \mathrm{~A}$ are extrapolated to field populations of T. thiebautii.

The communities associated with these clone libraries are, broadly speaking, similar to other surface associated communities. They are largely composed of Bacteroidetes, Alpha- and Gammaproteobacteria, as well as a few Planctomycees. However, consistent with the results presented in Chapter 4, the Trichodesmium spp. strains examined in this study are quite unlike other organisms which are represented in public databases (GenBank, based on a comparison of the $16 \mathrm{~S}$ rRNA gene). It is extremely exciting, despite the relatively small scale of the cultivation effort undertaken in this study, that some 'novel' organisms are present in the culture collection. With these epibionts in culture, we can evaluate them for novel metabolisms and explore their role in the epibiotic community.

The most unusual 16S sequences among cultivars are associated with H9-4A and IMS101 and are classified as Gammaproteobacteria, although they only share 86-88 PSI 
with known gammaproteobacterial 16S rRNA genes. H9-4A also hosts some of the more unusual cloned rRNA genes detected in this study; of particular note are unusual Planctomyces-like sequences.

The epibiont community associated with H9-4A has a number of unusual features, and it will be interesting to investigate some of these features in subsequent studies. One feature of particular note is high percentage of the gammaproteobacterial clones associated with H9-4A which are very similar to cultivated strains of Methylophaga marina (99 PSI or better). Fortuitously, an isolate with a 16S rRNA gene identical to these clones and Methylophaga marina (accession number X95459) was isolated. While the exchange of organic carbon and fixed nitrogen between cyanobacteria and heterotrophic bacteria is well-documented (Herbst \& Overbeck, 1978; Behrens et al., 2008), these exchanges have never been studied between Trichodesmium and its epibionts nor has the exchange of specific carbon-compounds been investigated. Methylophaga has been isolated in association with eukaryotic algae in the ocean (Janvier et al., 1985; Neufeld et al., 2008). Interest in these bacteria is driven by the possibility that the production of methanol in the ocean may contribute significantly to the atmospheric methanol inventory (Heikes et al., 2002). H9-4A and associated Methylophaga may well serve as a model system in which to study the exchange of a specific metabolite between Trichodesmium and its epibionts as well as the release of methanol from an algal-bacterial consortia in the ocean. Methylophaga species, $M$. marina in particular, may be well suited for such a targeted study because they are only capable of growth on a limited number of organic carbon substrates (Janvier et al., 1985). 
Not all of the unusual 16S rRNA gene sequences represented within the clone libraries generated in this study are matched by cultivars in the culture collection (e.g., the Planctomyces-like sequences described above). However, the original consortia from which they derive is in culture. This affords us the possibility of probing the ecological function of these taxa using culture independent means and/or extending our cultivation effort with a more targeted approach.

The presence of numerous novel organisms, both represented in the clone libraries and culture collection, reaffirms the result presented in Chapter 4; Trichodesmium spp. are capable of supporting organisms which have not yet been observed in the laboratory. From this result we may infer that Trichodesmium offers a unique (unexplored) environment to microbes in pelagic marine environments.

The results of this study highlight the fact that what we call 'Trichodesmium' is not one organism but it is a consortial community whose structure is highly variable depending on the environmental source of the colony and perhaps the laboratory environment in which it is cultivated; the ecology of the consortial community is likely to depend on its members and thus may also be variable. While experiments with laboratory cultivated strains are essential and have provided much of our insight into the role of Trichodesmium in the oceans, when we extrapolate the results of studies performed with IMS101 or H9-4A (or other model organisms) to T. erythraeum or T. thiebautii in the ocean, the composition of the heterotrophic community should be of greater consideration. 


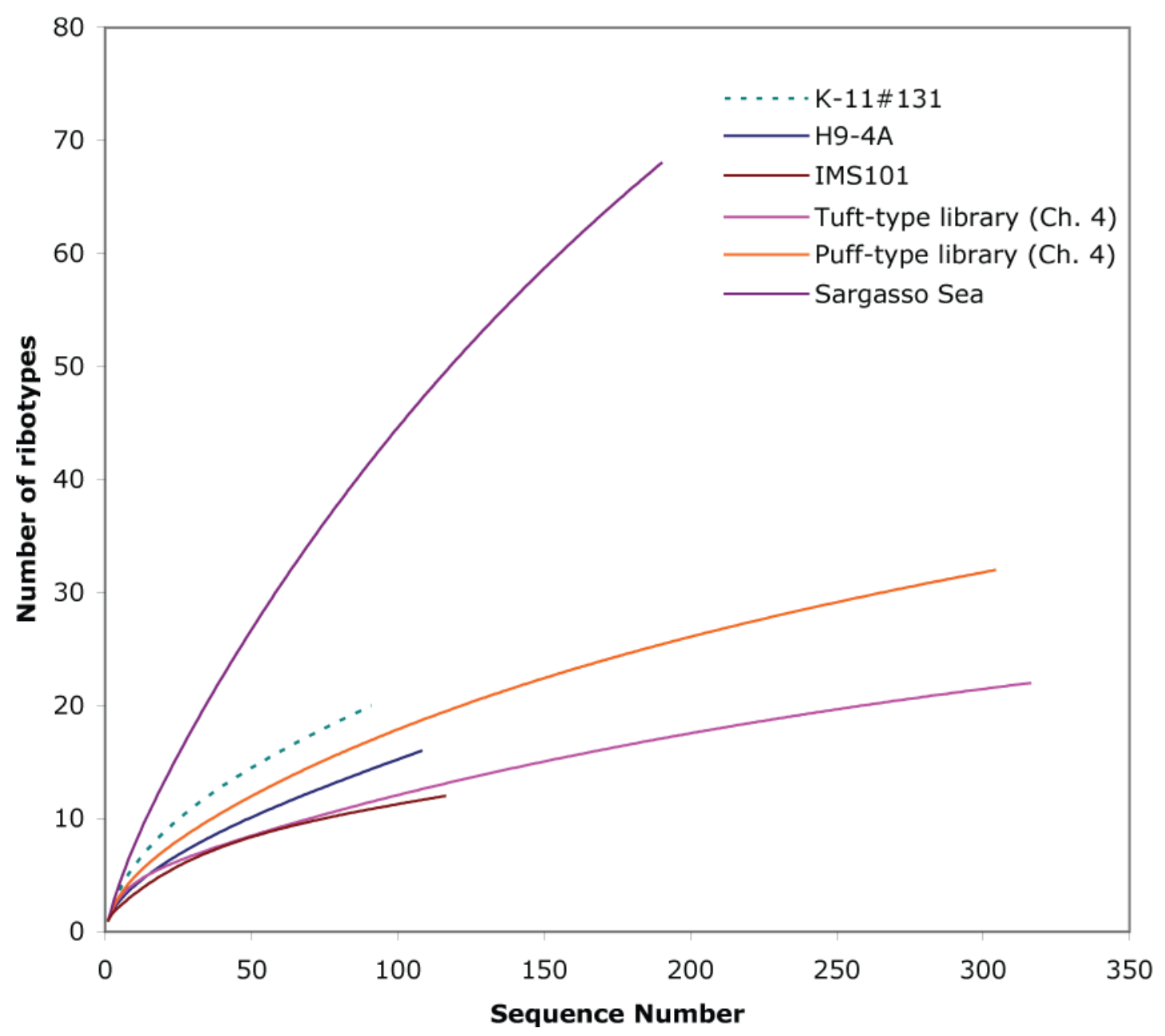

Figure 1. Rarefaction curve containing IMS101, K-11\#131, and H9-4A as well as datasets discussed in Chapter 4 for reference. Calculations were performed at 97 PSI by the FastGroup II program (97 PSI 'with gaps' algorithm, sequences were manually trimmed in ARB prior to submission to FastGroup II). 
IMS101

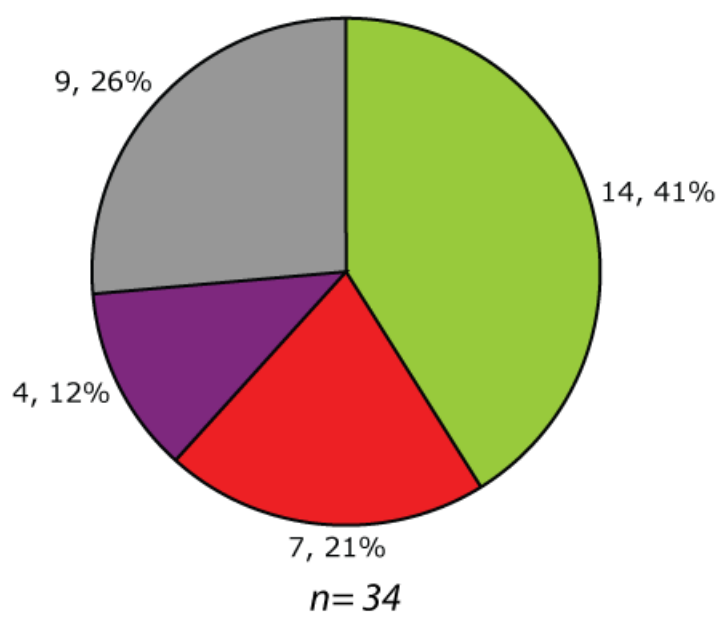

K11 131

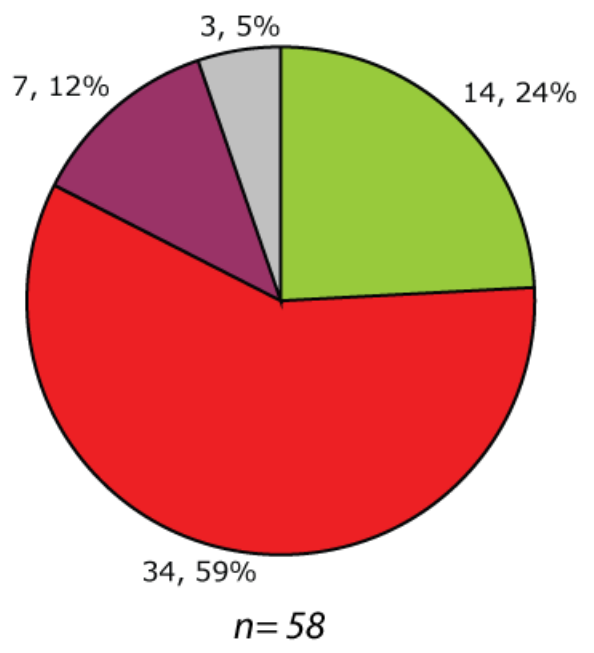

H94A

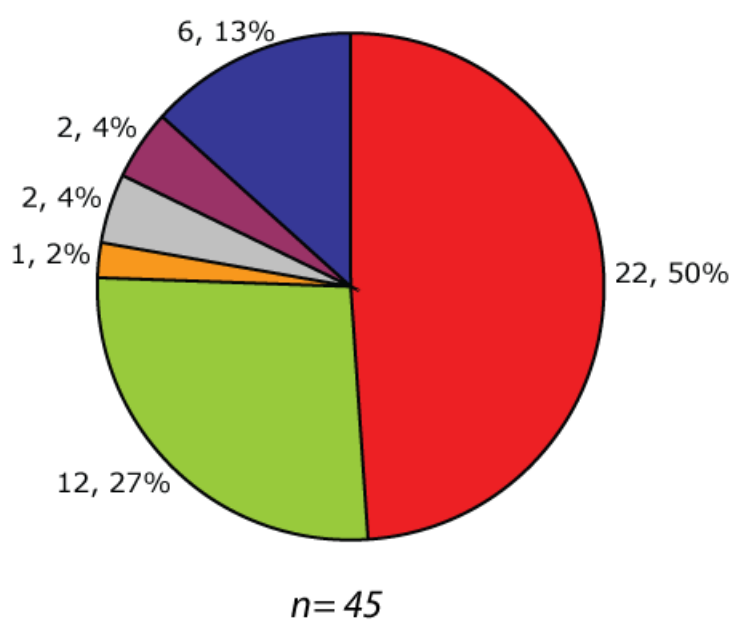

Figure 2. Class level comparison of K11 131, H9-4A, and IMS101 at 97 PSI. Values listed adjacent to each 'wedge' of the pie chart provide the number of clones in that category, followed by the percentage of the total non-cyanobacterial clones recovered. The number of non-cyanobacterial clones recovered is listed underneath each chart. 
Figure 3. Phylogenetic tree containing all alphaproteobacterial clones and isolates generated in this study, as well as reference sequences. This tree was created using Neighbor Joining algorithm in ARB and bootstrapped 1000 times using the neighbor joining algorithm in Phylip. Asterisks indicate bootstrap values of $70 \%$ or better. Sequences generated in this study are indicated by boldface type. Accession numbers are in parentheses following all sequences. 


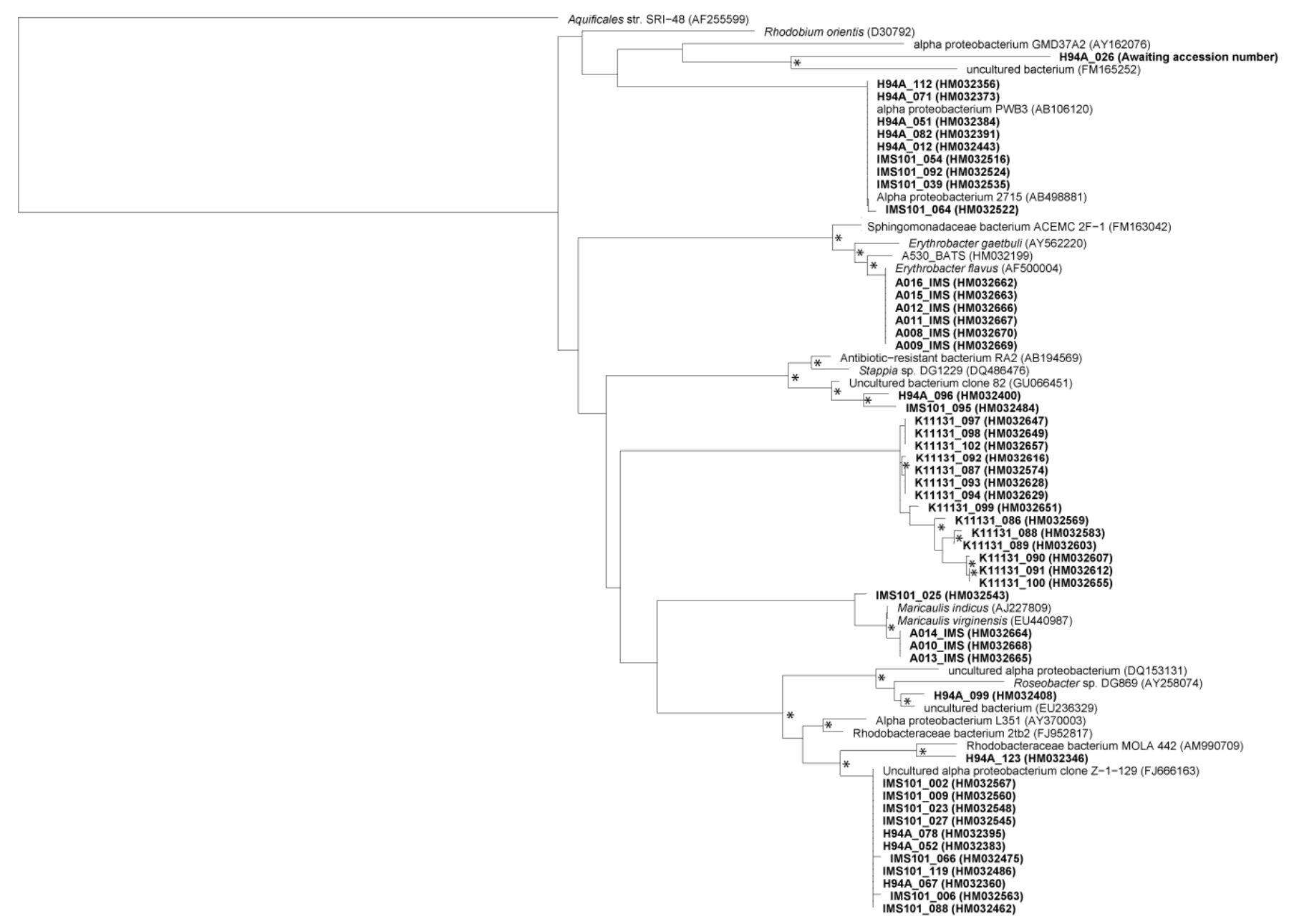


Figure 4. Phylogenetic tree containing all gammaproteobacterial clones and isolates generated in this study, as well as reference sequences. This tree was created using Neighbor Joining algorithm in ARB and bootstrapped 1000 times using the neighbor joining algorithm in Phylip. Asterisks indicate bootstrap values of $60 \%$ or better. Sequences generated in this study are indicated by boldface type. Accession numbers are in parentheses following all sequences. 


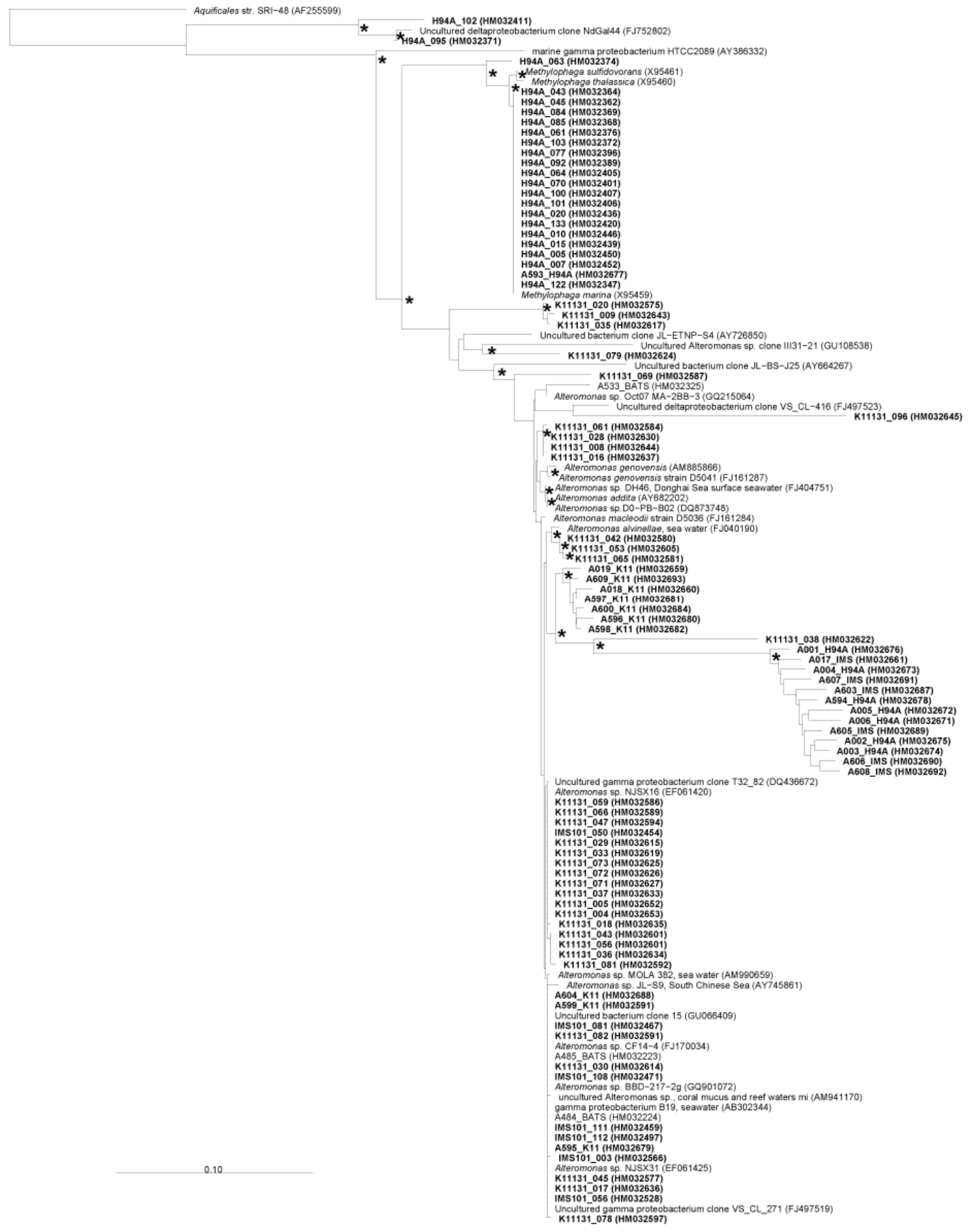


Figure 5. Phylogenetic tree containing all clones and isolates not assigned to the proteobacteria generated in this study, as well as reference sequences. This tree was created using Neighbor Joining algorithm in ARB and bootstrapped 1000 times using the neighbor joining algorithm in Phylip. Asterisks indicate bootstrap values of $70 \%$ or better. Sequences generated in this study are indicated by boldface type. Accession numbers are in parentheses following all sequences. 
Aquificales str. SRI-48 (AF255599)

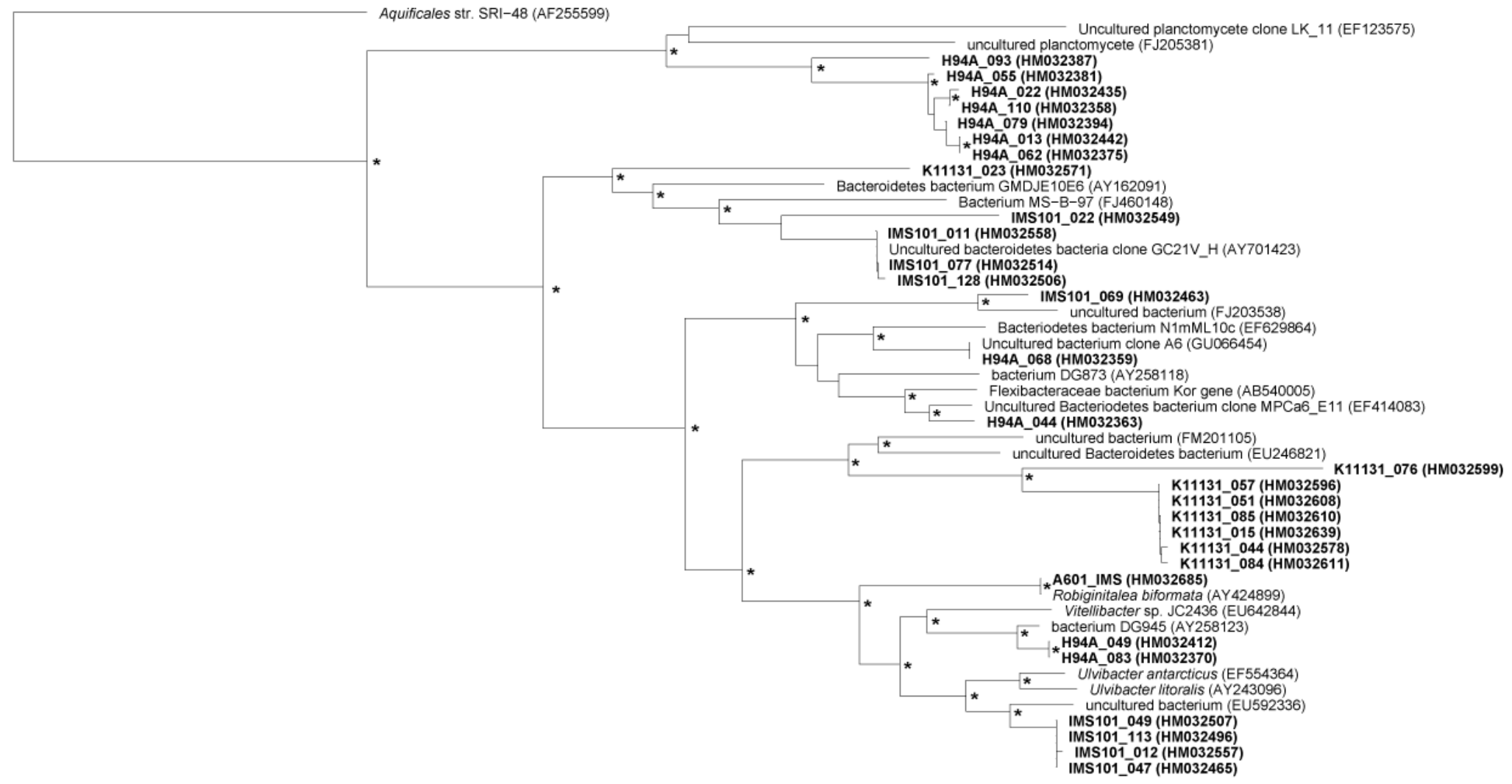




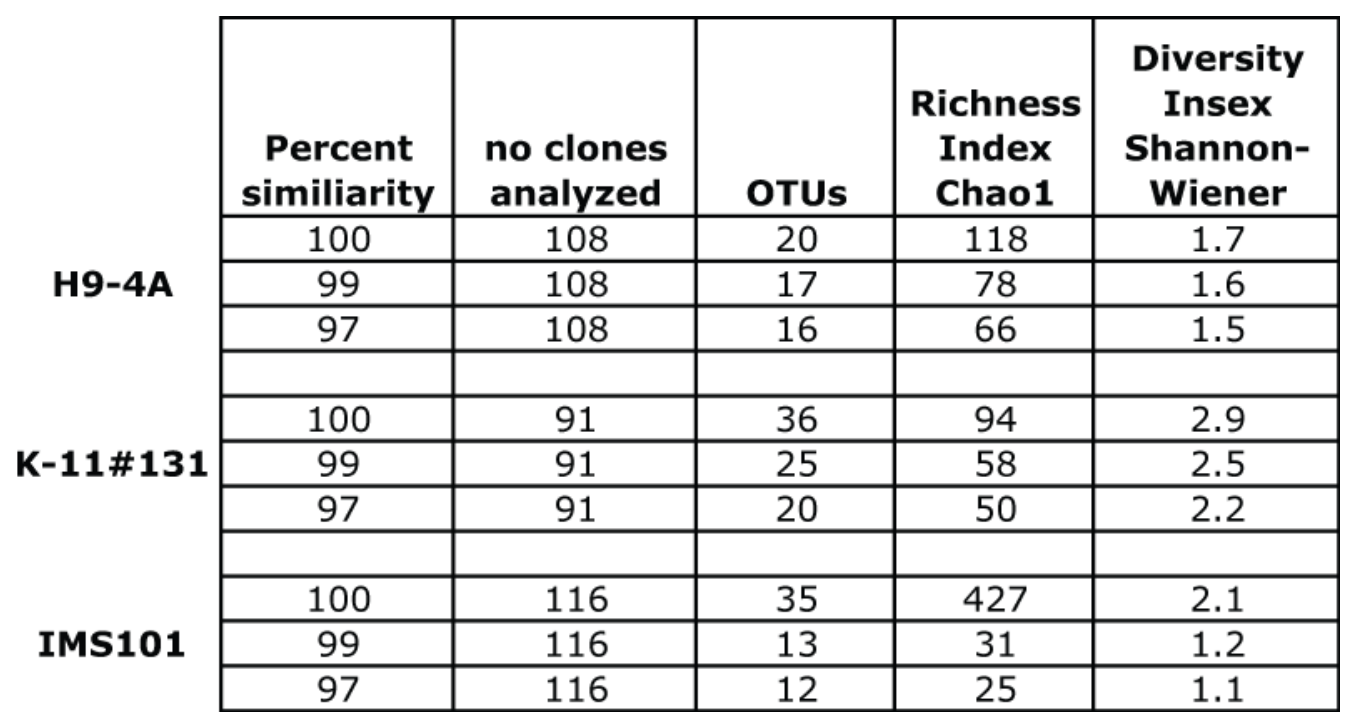

Table 1. Statistical description of K-11\#131, IMS101 and H9-4A clone libraries. OTUs, the Chaol richness index, and the Shannon-Wiener diversity index were all calculated using the FastGroup II website which is described in the Methods. The number of OTUs and the values of the Chaol and Shannon-Wiener indices are calculated at the 97, 99, and 100 percent sequence identity threshold (PSI). The results of the 97 PSI analysis are described in detail in the text. 
Table 2. Nearest GenBank neighbors of 97 PSI OTUs present within 16S rDNA clone libraries constructed from DNA extracted from K-11\#131 Trichodesmium colonies. In cases where the nearest neighbor is an uncultivated organism, the nearest cultivated organism is included as well. 


\begin{tabular}{|c|c|c|c|c|c|c|c|}
\hline $\begin{array}{l}\text { Clone ID } \\
(K 11131)\end{array}$ & $\begin{array}{l}\text { Accession } \\
\text { no. }\end{array}$ & Sequence ID of nearest BLAST match & $\begin{array}{l}\text { Accession no. } \\
\text { (BLAST match) }\end{array}$ & PSI & $\begin{array}{l}\text { Number of } \\
\text { bases } \\
\text { compared }\end{array}$ & Bit score & $\begin{array}{l}\text { Number of } \\
\text { clones } \\
\text { recovered }\end{array}$ \\
\hline 012 & HM032641 & Trichodesmium erythraeum IMS101 & CP000393 & 99 & 539 & 989 & 1 \\
\hline 055 & HM032602 & Trichodesmium erythraeum IMS101 & СР000393 & 99 & 539 & 979 & 29 \\
\hline 069 & HM032587 & Uncultured bacterium clone JL-BS-J25 16S ribosomal RNA gene & AY664267 & 90 & 552 & 710 & 1 \\
\hline 086 & HM032569 & $\begin{array}{l}\text { Uncultured bacterium clone Mann16S_E05 16S ribosomal RNA } \\
\text { gene }\end{array}$ & FJ952687 & 90 & 743 & 979 & 5 \\
\hline 086 & HM032569 & Woodsholensia maritima partial 16S rRNA gene, strain CM251 & AJ578477 & 90 & 691 & 896 & \\
\hline 092 & HM032616 & $\begin{array}{l}\text { Uncultured bacterium clone Mann16S_E05 16S ribosomal RNA } \\
\text { gene }\end{array}$ & FJ952687 & 91 & 736 & 1011 & 9 \\
\hline 092 & HM032616 & Woodsholensia maritima partial 16S rRNA gene, strain CM251 & AJ578477 & 91 & 690 & 922 & \\
\hline 017 & HM032636 & $\begin{array}{l}\text { Alteromonas sp. BBD-217-2g } 16 \text { S ribosomal RNA gene, partial } \\
\text { sequence }\end{array}$ & GQ901072 & 99 & 571 & 1048 & 2 \\
\hline 020 & HM032575 & $\begin{array}{l}\text { Uncultured gamma proteobacterium clone JL-ETNP-S4 16S } \\
\text { ribosomal RNA gene }\end{array}$ & AY726850 & 98 & 454 & 793 & 3 \\
\hline 020 & HM032575 & Alteromonas genovensis strain D5041 16S ribosomal RNA gene & FJ161287 & 98 & 439 & 771 & \\
\hline 030 & HM032614 & Uncultured bacterium clone 15 16S ribosomal RNA gene & GU066409 & 100 & 571 & 1055 & 20 \\
\hline 038 & HM032622 & Alteromonas sp. DH46 $16 \mathrm{~S}$ ribosomal RNA gene, partial sequence & FJ404751 & 90 & 574 & 752 & 1 \\
\hline 043 & HM032579 & Alteromonas sp. Oct07-MA-2BB-3 16S ribosomal RNA gene & GQ215064 & 97 & 588 & 989 & 4 \\
\hline 047 & HM032594 & $\begin{array}{l}\text { Uncultured gamma proteobacterium clone T32_82 16S ribosomal } \\
\text { RNA gene }\end{array}$ & DQ436672 & 100 & 572 & 1057 & 2 \\
\hline 047 & HM032594 & Alteromonas sp. CF14-4 16S ribosomal RNA gene & FJ170034 & 99 & 572 & 1051 & \\
\hline 079 & HM032624 & Uncultured Alteromonas sp. clone F3C95 $16 \mathrm{~S}$ ribosomal RNA gene & AY936198 & 93 & 567 & 841 & 1 \\
\hline 096 & HM032645 & Alteromonas sp. SKUK MB1007 16S ribosomal RNA gene & EU907922 & 87 & 533 & 597 & \\
\hline 023 & HM032571 & $\begin{array}{l}\text { Uncultured Bacteroidetes bacterium clone GC21V_H } 16 \mathrm{~S} \text { small } \\
\text { subunit ribosomal RNA gene }\end{array}$ & AY701423 & 92 & 455 & 636 & 1 \\
\hline 076 & HM032599 & $\begin{array}{l}\text { Uncultured bacterium partial 16S rRNA gene, clone MBR- } \\
\text { 8_LF_BF99 }\end{array}$ & FM201105 & 85 & 548 & 540 & 1 \\
\hline 084 & HM032611 & $\begin{array}{l}\text { Uncultured Bacteroidetes bacterium clone Cobs2TisF6 16S } \\
\text { ribosomal RNA gene }\end{array}$ & EU246821 & 86 & 584 & 645 & 6 \\
\hline 096 & HM032645 & $\begin{array}{l}\text { Uncultured Bacteroidetes bacterium clone GC21V_H } 16 \text { S small } \\
\text { subunit ribosomal RNA gene }\end{array}$ & AY701423 & 93 & 412 & 606 & 1 \\
\hline
\end{tabular}


Table 3. Nearest GenBank neighbors of 97 PSI OTUs present within 16S rDNA clone libraries constructed from DNA extracted from H9-4A Trichodesmium colonies. In cases where the nearest neighbor is an uncultivated organism, the nearest cultivated organism is included as well. 


\begin{tabular}{|c|c|c|c|c|c|c|c|}
\hline $\begin{array}{l}\text { Clone ID } \\
(H 94 A\lrcorner\end{array}$ & $\begin{array}{l}\text { Accession } \\
\text { no. }\end{array}$ & Sequence ID of nearest BLAST match & $\begin{array}{l}\text { Accession no. } \\
\text { (BLAST match) }\end{array}$ & PSI & $\begin{array}{l}\text { Number of } \\
\text { bases } \\
\text { compared }\end{array}$ & Bit score & $\begin{array}{l}\text { Number of } \\
\text { clones } \\
\text { recovered }\end{array}$ \\
\hline 066 & HM032403 & Trichodesmium thiebautii $16 \mathrm{~S}$ ribosomal RNA gene & AF013027 & 99 & 564 & 1037 & 63 \\
\hline 012 & HM032443 & Alpha proteobacterium 2715 gene for 16 S rRNA & AB498881 & 100 & 563 & 1040 & 5 \\
\hline 026 & & \multirow{2}{*}{$\begin{array}{l}\text { Uncultured bacterium partial } 16 \mathrm{~S} \text { rRNA gene, clone V2tb43 } \\
\text { Alpha proteobacterium GMD37A2 small subunit ribosomal RNA } \\
\text { gene }\end{array}$} & FM165252 & 90 & 583 & 767 & \multirow[t]{2}{*}{1} \\
\hline 026 & & & AY162076 & 95 & 442 & 688 & \\
\hline 067 & HM032360 & $\begin{array}{l}\text { Uncultured alpha proteobacterium clone Z-1-129 16S ribosomal } \\
\text { RNA gene }\end{array}$ & FJ666163 & 100 & 563 & 1040 & \multirow[t]{2}{*}{3} \\
\hline 067 & HМ032360 & Rhodobacteraceae bacterium 2tb2 $16 \mathrm{~S}$ ribosomal RNA gene & FJ952817 & 97 & 563 & 952 & \\
\hline 096 & HM032400 & Uncultured bacterium clone $8216 \mathrm{~S}$ ribosomal RNA gene & GU066451 & 98 & 565 & 985 & \multirow[t]{2}{*}{1} \\
\hline 096 & HМ032400 & Antibiotic-resistant bacterium RA2 gene for $16 \mathrm{~S}$ rRNA & AB194569 & 96 & 566 & 929 & \\
\hline 099 & HM032408 & Uncultured bacterium clone Hg5a1F11 16S ribosomal RNA gene & EU236329 & 99 & 563 & 1013 & \multirow[t]{2}{*}{1} \\
\hline 099 & HМ032408 & Marine sponge bacterium FILTER13C237 16S ribosomal RNA gene & EU346412 & 98 & 563 & 996 & \\
\hline 123 & HM032346 & Rhodobacteraceae bacterium MOLA 442 partial 16S rRNA gene & AM990709 & 98 & 563 & 979 & 1 \\
\hline 015 & HM032439 & Methylophaga marina mRNA for $16 \mathrm{~S}$ ribosomal RNA & X95459 & 100 & 602 & 1112 & 19 \\
\hline 093 & HM032387 & Uncultured planctomycete clone II9E $16 \mathrm{~S}$ ribosomal RNA gene & FJ205381 & 86 & 471 & 499 & \multirow[t]{2}{*}{1} \\
\hline 093 & HM032387 & Alteromonas sp. D0-PB-B02 16S ribosomal RNA gene & DQ873748 & 80 & 614 & 438 & \\
\hline 095 & HМ032371 & $\begin{array}{l}\text { Uncultured delta proteobacterium clone NdGal44 } 16 \mathrm{~S} \text { ribosomal } \\
\text { RNA gene }\end{array}$ & FJ752802 & 99 & 590 & 1074 & \multirow[t]{2}{*}{1} \\
\hline 095 & HМ032371 & $\begin{array}{l}\text { Marine sponge bacterium LIQUIDdw06F03 16S ribosomal RNA } \\
\text { gene }\end{array}$ & EU346460 & 98 & 579 & 1020 & \\
\hline 102 & HM032411 & $\begin{array}{l}\text { Uncultured delta proteobacterium clone NdGal44 16S ribosomal } \\
\text { RNA gene }\end{array}$ & FJ752802 & 93 & 594 & 880 & \multirow[t]{2}{*}{1} \\
\hline 102 & HM032411 & $\begin{array}{l}\text { Marine sponge bacterium LIQUIDdw06F03 16S ribosomal RNA } \\
\text { gene }\end{array}$ & EU346460 & 93 & 583 & 854 & \\
\hline 068 & HM032359 & Uncultured bacterium clone A6 16S ribosomal RNA gene & GU066454 & 100 & 599 & 1107 & \multirow[t]{2}{*}{1} \\
\hline 068 & HM032359 & Bacteroidetes bacterium $\mathrm{N} 1 \mathrm{mML} 10 \mathrm{c} 16 \mathrm{~S}$ ribosomal RNA gene & EF629864 & 93 & 603 & 902 & \\
\hline 083 & HM032370 & Bacterium DG945 small subunit ribosomal RNA gene & AY258123 & 97 & 600 & 1016 & 2 \\
\hline 044 & HM032363 & $\begin{array}{l}\text { Uncultured Bacteroidetes bacterium clone MPCa6_E11 16S } \\
\text { ribosomal RNA gene }\end{array}$ & EF414083 & 97 & 601 & 1035 & \multirow[t]{2}{*}{1} \\
\hline 044 & HМ032363 & Flexibacteraceae bacterium Kor gene for $16 \mathrm{~S}$ rRNA & AB540005 & 95 & 603 & 968 & \\
\hline 062 & HM032375 & Uncultured planctomycete clone LK_11 16S ribosomal RNA gene & EF123575 & 85 & 638 & 640 & 6 \\
\hline
\end{tabular}


Table 4. Nearest GenBank neighbors of 97 PSI OTUs present within 16S rDNA clone libraries constructed from DNA extracted from IMS101 Trichodesmium colonies. In cases where the nearest neighbor is an uncultivated organism, the nearest cultivated organism is included as well.

\begin{tabular}{|c|c|c|c|c|c|c|c|}
\hline $\begin{array}{l}\text { Clone ID } \\
\text { (IMS101_) }\end{array}$ & $\begin{array}{l}\text { Accession } \\
\text { no. }\end{array}$ & Sequence ID of nearest BLAST match & $\begin{array}{l}\text { Accession no. } \\
\text { (BLAST match) }\end{array}$ & PSI & $\begin{array}{l}\text { Number of } \\
\text { bases } \\
\text { compared }\end{array}$ & Bit score & $\begin{array}{l}\text { Number of } \\
\text { clones } \\
\text { recovered }\end{array}$ \\
\hline 001 & HM032568 & Trichodesmium erythraeum IMS101, complete genome & СР000393 & 99 & 573 & 1051 & 1 \\
\hline 008 & HM032561 & Trichodesmium erythraeum IMS101, complete genome & СР000393 & 100 & 573 & 1059 & 85 \\
\hline 006 & HM032563 & Uncultured alpha proteobacterium clone Z-1-129 $16 \mathrm{~S}$ ribosomal RNA gene & FJ666163 & 99 & 572 & 1051 & 8 \\
\hline 006 & HM032563 & Rhodobacteraceae bacterium 2tb2 16S ribosomal RNA gene & FJ952817 & 97 & 572 & 963 & \\
\hline 025 & HM032543 & Maricaulis virginensis strain PR54-12 $16 \mathrm{~S}$ ribosomal RNA gene & EU440987 & 98 & 572 & 1018 & 1 \\
\hline 092 & HM032524 & Alpha proteobacterium PWB3 gene for $16 \mathrm{~S}$ rRNA & AB106120 & 100 & 572 & 1057 & 4 \\
\hline 095 & HM032484 & Uncultured bacterium clone $8216 \mathrm{~S}$ ribosomal RNA gene & GU066451 & 98 & 574 & 1007 & 1 \\
\hline 095 & HM032484 & Antibiotic-resistant bacterium RA2 gene for $16 \mathrm{~S}$ rRNA & AB194569 & 96 & 575 & 952 & \\
\hline 081 & HM032467 & Alteromonas sp. BBD-217-2g 16S ribosomal RNA gene & GQ901072 & 100 & 605 & 1118 & 5 \\
\hline 111 & HM032459 & $\begin{array}{l}\text { Uncultured gamma proteobacterium clone VS_CL-271 16S ribosomal RNA } \\
\text { gene }\end{array}$ & FJ497519 & 100 & 606 & 1120 & 2 \\
\hline 111 & HM032459 & Alteromonas sp. CF14-4 16S ribosomal RNA gene & FJ170034 & 100 & 606 & 1120 & \\
\hline 022 & HM032549 & $\begin{array}{l}\text { Uncultured Bacteroidetes bacterium clone GC21V_H } 16 \mathrm{~S} \text { small subunit } \\
\text { ribosomal RNA gene }\end{array}$ & AY701423 & 92 & 611 & 880 & 1 \\
\hline 022 & HM032549 & Bacterium MS-B-97 16S ribosomal RNA gene & FJ460148 & 89 & 560 & 682 & \\
\hline 049 & HM032507 & Uncultured bacterium clone SSW3Ap 16S ribosomal RNA gene & EU592336 & 94 & 611 & 939 & 4 \\
\hline 049 & HM032507 & Ulvibacter antarcticus strain IMCC3101 16S ribosomal RNA gene & EF554364 & 93 & 608 & 911 & \\
\hline 069 & HM032463 & Uncultured bacterium clone SHFH609 16S ribosomal RNA gene & FJ203538 & 94 & 612 & 952 & 1 \\
\hline 069 & HM032463 & Bacterium DG873 small subunit ribosomal RNA gene & AY258118 & 88 & 622 & 739 & \\
\hline 077 & HM032514 & $\begin{array}{l}\text { Uncultured Bacteroidetes bacterium clone GC21V_H } 16 \mathrm{~S} \text { small subunit } \\
\text { ribosomal RNA gene }\end{array}$ & AY701423 & 100 & 612 & 1131 & 3 \\
\hline 077 & HM032514 & Bacteroidetes bacterium GMDJE10E6 small subunit ribosomal RNA gene & AY162091 & 92 & 618 & 876 & \\
\hline
\end{tabular}


Table 5. Nearest GenBank neighbors of cultivars isolated from T. erythraeum strain K-11\#131 colonies.

\begin{tabular}{|c|c|c|c|c|c|c|c|}
\hline Isolate ID & $\begin{array}{l}\text { Accession } \\
\text { no. }\end{array}$ & Sequence ID of nearest BLAST match & $\begin{array}{l}\text { Accession no. } \\
\text { (BLAST match) }\end{array}$ & PSI & $\begin{array}{l}\text { Number of } \\
\text { bases } \\
\text { compared }\end{array}$ & Bit score & Lineage \\
\hline A019_K11 & HM032659 & $\begin{array}{l}\text { Gamma proteobacterium B19 gene for } 16 \mathrm{~S} \text { rRNA, partial } \\
\text { sequence }\end{array}$ & AB302344 & 98 & 626 & 1090 & $\begin{array}{l}\text { Bacteria; Proteobacteria; } \\
\text { Gammaproteobacteria; Alteromonadales; } \\
\text { Alteromonadaceae; Alteromonas. }\end{array}$ \\
\hline A018_K11 & HM032660 & Alteromonas sp. MOLA 382 partial $16 \mathrm{~S}$ rRNA gene & AM990659 & 97 & 645 & 1120 & $\begin{array}{l}\text { Bacteria; Proteobacteria; } \\
\text { Gammaproteobacteria; Alteromonadales; } \\
\text { Alteromonadaceae; Alteromonas. }\end{array}$ \\
\hline A595_K11 & HM032679 & Alteromonas sp. NJSX31 16S ribosomal RNA gene & EF061425 & 99 & 734 & 1351 & $\begin{array}{l}\text { Bacteria; Proteobacteria; } \\
\text { Gammaproteobacteria; Alteromonadales; } \\
\text { Alteromonadaceae; Alteromonas. }\end{array}$ \\
\hline A596_K11 & HM032680 & $\begin{array}{l}\text { Alteromonas alvinellae strain MED76 } 16 \mathrm{~S} \text { ribosomal RNA } \\
\text { gene }\end{array}$ & AY136113 & 97 & 717 & 1230 & $\begin{array}{l}\text { Bacteria; Proteobacteria; } \\
\text { Gammaproteobacteria; Alteromonadales; } \\
\text { Alteromonadaceae; Alteromonas. }\end{array}$ \\
\hline A597_K11 & HM032681 & Alteromonas alvinellae strain MED76 16S ribosomal RNA gene & AY136113 & 98 & 651 & 1142 & $\begin{array}{l}\text { Bacteria; Proteobacteria; } \\
\text { Gammaproteobacteria; Alteromonadales; } \\
\text { Alteromonadaceae; Alteromonas. }\end{array}$ \\
\hline A598_K11 & HM032682 & Alteromonas alvinellae strain MED76 $16 \mathrm{~S}$ ribosomal RNA gene & AY136113 & 98 & 638 & 1118 & $\begin{array}{l}\text { Bacteria; Proteobacteria; } \\
\text { Gammaproteobacteria; Alteromonadales; } \\
\text { Alteromonadaceae; Alteromonas. }\end{array}$ \\
\hline A599_K11 & HM032683 & Alteromonas sp. NJSX31 16S ribosomal RNA gene & EF061425 & 99 & 739 & 1360 & $\begin{array}{l}\text { Bacteria; Proteobacteria; } \\
\text { Gammaproteobacteria; Alteromonadales; } \\
\text { Alteromonadaceae; Alteromonas. }\end{array}$ \\
\hline A600_K11 & HM032684 & Alteromonas alvinellae strain MED76 16S ribosomal RNA gene & AY136113 & 97 & 675 & 1170 & $\begin{array}{l}\text { Bacteria; Proteobacteria; } \\
\text { Gammaproteobacteria; Alteromonadales; } \\
\text { Alteromonadaceae; Alteromonas. }\end{array}$ \\
\hline A604_K11 & HM032688 & Alteromonas sp. NJSX31 $16 \mathrm{~S}$ ribosomal RNA gene & EF061425 & 99 & 737 & 1356 & $\begin{array}{l}\text { Bacteria; Proteobacteria; } \\
\text { Gammaproteobacteria; Alteromonadales; } \\
\text { Alteromonadaceae; Alteromonas. }\end{array}$ \\
\hline A609_K11 & HM032693 & Alteromonas alvinellae strain MED76 $16 \mathrm{~S}$ ribosomal RNA gene & AY136113 & 97 & 717 & 1242 & $\begin{array}{l}\text { Bacteria; Proteobacteria; } \\
\text { Gammaproteobacteria; Alteromonadales; } \\
\text { Alteromonadaceae; Alteromonas. }\end{array}$ \\
\hline
\end{tabular}


Table 6. Nearest GenBank neighbors of cultivars isolated from T. thiebautii strain H9-4A colonies.

\begin{tabular}{|c|c|c|c|c|c|c|c|}
\hline Isolate ID & $\begin{array}{c}\text { Accession } \\
\text { no. }\end{array}$ & Sequence ID of nearest BLAST match & $\begin{array}{l}\text { Accession no. } \\
\text { (BLAST match) }\end{array}$ & PSI & $\begin{array}{c}\text { Number of } \\
\text { bases } \\
\text { compared }\end{array}$ & Bit score & Lineage \\
\hline A006_H94A & HM032671 & Alteromonas sp. CF14-4 $16 \mathrm{~S}$ ribosomal RNA gene & FJ170034 & 87 & 680 & 758 & $\begin{array}{l}\text { Bacteria; Proteobacteria; } \\
\text { Gammaproteobacteria; Alteromonadales; } \\
\text { Alteromonadaceae; Alteromonas. }\end{array}$ \\
\hline A005_H94A & HM032672 & Alteromonas sp. CF14-4 $16 \mathrm{~S}$ ribosomal RNA gene & FJ170034 & 87 & 621 & 695 & $\begin{array}{l}\text { Bacteria; Proteobacteria; } \\
\text { Gammaproteobacteria; Alteromonadales; } \\
\text { Alteromonadaceae; Alteromonas. }\end{array}$ \\
\hline A004_H94A & HM032673 & Alteromonas sp. CF14-4 $16 \mathrm{~S}$ ribosomal RNA gene & FJ170034 & 88 & 668 & 785 & $\begin{array}{l}\text { Bacteria; Proteobacteria; } \\
\text { Gammaproteobacteria; Alteromonadales; } \\
\text { Alteromonadaceae; Alteromonas. }\end{array}$ \\
\hline A003_H94A & HM032674 & Alteromonas sp. CF14-4 $16 \mathrm{~S}$ ribosomal RNA gene & FJ170034 & 87 & 619 & 697 & $\begin{array}{l}\text { Bacteria; Proteobacteria; } \\
\text { Gammaproteobacteria; Alteromonadales; } \\
\text { Alteromonadaceae; Alteromonas. }\end{array}$ \\
\hline A002_H94A & HM032675 & Alteromonas sp. CF14-4 $16 \mathrm{~S}$ ribosomal RNA gene & FJ170034 & 86 & 689 & 767 & $\begin{array}{l}\text { Bacteria; Proteobacteria; } \\
\text { Gammaproteobacteria; Alteromonadales; } \\
\text { Alteromonadaceae; Alteromonas. }\end{array}$ \\
\hline A001_H94A & HM032676 & Alteromonas sp. CF14-4 $16 \mathrm{~S}$ ribosomal RNA gene & FJ170034 & 88 & 690 & 815 & $\begin{array}{l}\text { Bacteria; Proteobacteria; } \\
\text { Gammaproteobacteria; Alteromonadales; } \\
\text { Alteromonadaceae; Alteromonas. }\end{array}$ \\
\hline A593_H94A & HM032677 & Methylophaga marina mRNA for $16 \mathrm{~S}$ ribosomal RNA & X95459 & 100 & 690 & 1275 & $\begin{array}{l}\text { Bacteria; Proteobacteria; } \\
\text { Gammaproteobacteria; } \\
\text { Thiotrichales;Piscirickettsiaceae; } \\
\text { Methvlophaqa }\end{array}$ \\
\hline A594_H94A & HM032678 & Alteromonas sp. CF14-4 $16 \mathrm{~S}$ ribosomal RNA gene & FJ170034 & 88 & 629 & 739 & $\begin{array}{l}\text { Bacteria; Proteobacteria; } \\
\text { Gammaproteobacteria; Alteromonadales; } \\
\text { Alteromonadaceae; Alteromonas. }\end{array}$ \\
\hline
\end{tabular}

Table 7. (displayed on next 2 pages) Nearest GenBank neighbors of cultivars isolated from T. thiebautii strain IMS101. 


\begin{tabular}{|c|c|c|c|c|c|c|c|}
\hline Isolate ID & $\begin{array}{l}\text { Accession } \\
\text { no. }\end{array}$ & Sequence ID of nearest BLAST match & $\begin{array}{l}\text { Accession no. } \\
\text { (BLAST match) }\end{array}$ & PSI & $\begin{array}{l}\text { Number of } \\
\text { bases } \\
\text { compared }\end{array}$ & Bit score & Lineage \\
\hline A015_IMS & HM032663 & Erythrobacter flavus strain D5033 $16 \mathrm{~S}$ ribosomal RNA gene & FJ161282 & 100 & 714 & 1319 & $\begin{array}{l}\text { Bacteria; Proteobacteria; } \\
\text { Alphaproteobacteria; } \\
\text { Sphingomonadales; Erythrobacteraceae; } \\
\text { Erythrobacter }\end{array}$ \\
\hline A014_IMS & HM032664 & Maricaulis sp. DNA for $16 \mathrm{~S}$ ribosomal RNA, strain MCS26 & AJ227809 & 99 & 745 & 1365 & $\begin{array}{l}\text { Bacteria; Proteobacteria; } \\
\text { Alphaproteobacteria; Rhodobacterales; } \\
\text { Hyphomonadaceae; Maricaulis }\end{array}$ \\
\hline A013_IMS & HМ032665 & Maricaulis sp. DNA for $16 \mathrm{~S}$ ribosomal RNA, strain MCS26 & AJ227809 & 99 & 752 & 1378 & $\begin{array}{l}\text { Bacteria; Proteobacteria; } \\
\text { Alphaproteobacteria; Rhodobacterales; } \\
\text { Hyphomonadaceae; Maricaulis }\end{array}$ \\
\hline A012_IMS & HM032666 & Bacterium daSW.33 $16 \mathrm{~S}$ ribosomal RNA gene & EU935320 & 100 & 716 & 1323 & $\begin{array}{l}\text { Bacteria; Proteobacteria; } \\
\text { Alphaproteobacteria; } \\
\text { Sphingomonadales; Erythrobacteraceae; } \\
\text { Erythrobacter }\end{array}$ \\
\hline A011_IMS & HМ032667 & Bacterium daSW.33 $16 \mathrm{~S}$ ribosomal RNA gene & EU935320 & 100 & 761 & 1406 & $\begin{array}{l}\text { Bacteria; Proteobacteria; } \\
\text { Alphaproteobacteria; } \\
\text { Sphingomonadales; Erythrobacteraceae; } \\
\text { Ervthrobacter }\end{array}$ \\
\hline A010_IMS & HM032668 & Maricaulis sp. DNA for $16 \mathrm{~S}$ ribosomal RNA, strain MCS 26 & AJ227809 & 99 & 736 & 1360 & $\begin{array}{l}\text { Bacteria; Proteobacteria; } \\
\text { Alphaproteobacteria; Rhodobacterales; } \\
\text { Hyphomonadaceae; Maricaulis }\end{array}$ \\
\hline A009_IMS & HМ032669 & Erythrobacter flavus strain D5033 16S ribosomal RNA gene & FJ161282 & 100 & 715 & 1321 & $\begin{array}{l}\text { Bacteria; Proteobacteria; } \\
\text { Alphaproteobacteria; } \\
\text { Sphingomonadales; Erythrobacteraceae; } \\
\text { Ervthrobacter }\end{array}$ \\
\hline A008_IMS & HM032670 & Bacterium daSW.33 $16 \mathrm{~S}$ ribosomal RNA gene & EU935320 & 100 & 749 & 1384 & $\begin{array}{l}\text { Bacteria; Proteobacteria; } \\
\text { Alphaproteobacteria; } \\
\text { Sphingomonadales; Erythrobacteraceae; } \\
\text { Ervthrobacter }\end{array}$ \\
\hline A601_IMS & HМ032685 & $\begin{array}{l}\text { Robiginitalea biformata strain HTCC2501 } 16 \text { S ribosomal RNA } \\
\text { gene }\end{array}$ & AY424899 & 100 & 725 & 1339 & $\begin{array}{l}\text { Bacteria; Bacteroidetes; Flavobacteria; } \\
\text { Flavobacteriales;Flavobacteriaceae; } \\
\text { Robiginitalea }\end{array}$ \\
\hline A602_IMS & HM032686 & Maricaulis virginensis strain PR54-12 $16 \mathrm{~S}$ ribosomal RNA gene & EU440987 & 99 & 616 & 1122 & $\begin{array}{l}\text { Bacteria; Proteobacteria; } \\
\text { Alphaproteobacteria; Rhodobacterales; } \\
\text { Hyphomonadaceae; Maricaulis }\end{array}$ \\
\hline A603_IMS & HM032687 & Alteromonas sp. CF14-4 $16 \mathrm{~S}$ ribosomal RNA gene & FJ170034 & 87 & 630 & 732 & $\begin{array}{l}\text { Bacteria; Proteobacteria; } \\
\text { Gammaproteobacteria; Alteromonadales; } \\
\text { Alteromonadaceae; Alteromonas. }\end{array}$ \\
\hline
\end{tabular}




\begin{tabular}{|c|c|c|c|c|c|c|c|}
\hline Isolate ID & $\begin{array}{c}\text { Accession } \\
\text { no. }\end{array}$ & Sequence ID of nearest BLAST match & $\begin{array}{l}\text { Accession no. } \\
\text { (BLAST match) }\end{array}$ & PSI & $\begin{array}{l}\text { Number of } \\
\text { bases } \\
\text { compared }\end{array}$ & Bit score & Lineage \\
\hline A605_IMS & HM032689 & Alteromonas sp. CF14-4 $16 \mathrm{~S}$ ribosomal RNA gene & FJ170034 & 88 & 629 & 739 & $\begin{array}{l}\text { Bacteria; Proteobacteria; } \\
\text { Gammaproteobacteria; Alteromonadales; } \\
\text { Alteromonadaceae; Alteromonas. }\end{array}$ \\
\hline A606_IMS & HM032690 & Alteromonas sp. CF14-4 $16 \mathrm{~S}$ ribosomal RNA gene & FJ170034 & 87 & 612 & 706 & $\begin{array}{l}\text { Bacteria; Proteobacteria; } \\
\text { Gammaproteobacteria; Alteromonadales; } \\
\text { Alteromonadaceae; Alteromonas. }\end{array}$ \\
\hline A607_IMS & HM032691 & Alteromonas sp. CF14-4 $16 \mathrm{~S}$ ribosomal RNA gene & FJ170034 & 88 & 623 & 747 & $\begin{array}{l}\text { Bacteria; Proteobacteria; } \\
\text { Gammaproteobacteria; Alteromonadales; } \\
\text { Alteromonadaceae; Alteromonas. }\end{array}$ \\
\hline A608_IMS & HM032692 & Alteromonas sp. CF14-4 $16 \mathrm{~S}$ ribosomal RNA gene & FJ170034 & 87 & 628 & 721 & $\begin{array}{l}\text { Bacteria; Proteobacteria; } \\
\text { Gammaproteobacteria; Alteromonadales; } \\
\text { Alteromonadaceae; Alteromonas. }\end{array}$ \\
\hline A017_IMS & HM032661 & Alteromonas sp. CF14-4 $16 \mathrm{~S}$ ribosomal RNA gene & FJ170034 & 88 & 618 & 736 & $\begin{array}{l}\text { Bacteria; Proteobacteria; } \\
\text { Gammaproteobacteria; Alteromonadales; } \\
\text { Alteromonadaceae; Alteromonas. }\end{array}$ \\
\hline A016_IMS & HM032662 & Bacterium daSW.33 $16 \mathrm{~S}$ ribosomal RNA gene & EU935320 & 100 & 731 & 1351 & $\begin{array}{l}\text { Bacteria; Proteobacteria; } \\
\text { Alphaproteobacteria; } \\
\text { Sphingomonadales; Erythrobacteraceae; } \\
\text { Erythrobacter }\end{array}$ \\
\hline
\end{tabular}




\section{REFERENCES}

Baalen, C. V. (1961) Vitamin B12 Requirement of a Marine Blue-Green Alga. Science 133: $1922-1923$.

Barbeau, K., Roe, K., \& Mann, E. (2010) Microbial interactions and the marine biogeochemistry of iron in the Trichodesmium colony microenvironment. Eos Trans AGU 91:

Behrens, S., Losekann, T., Pett-Ridge, J., Weber, P. K., Ng, W. O., Stevenson, B. S. et al. (2008) Linking microbial phylogeny to metabolic activity at the single-cell level by using enhanced element labeling-catalyzed reporter deposition fluorescence in situ hybridization (EL-FISH) and NanoSIMS. Appl Environ Microbiol 74: 3143.

Burkholder, P. R. (1963) Some nutritional relationships among microbes of sea sediments and waters. 133-150.

Croft, M. T., Lawrence, A. D., Raux-Deery, E., Warren, M. J., \& Smith, A. G. (2005) Algae acquire vitamin B 12 through a symbiotic relationship with bacteria. Nature 438: $90-93$.

Heikes, B. G., Chang, W., Pilson, M. E. Q., Swift, E., Singh, H. B., Guenther, A. et al. (2002) Atmospheric methanol budget and ocean implication. Global Biogeochem Cy 16: 1133 .

Herbst, V., \& Overbeck, J. (1978) Metabolic coupling between the alga Oscillatoria redekei and accompanying bacteria. Naturwissenschaften 65: 598-599.

Janvier, M., Frehel, C., Grimont, F., \& Gasser, F. (1985) Methylophaga marina gen. nov., sp. nov. and Methylophaga thalassica sp. nov., marine methylotrophs. Int J Syst Evol Microbiol 35: 131.

Neufeld, J. D., Boden, R., Moussard, H., Schafer, H., \& Murrell, J. C. (2008) Substratespecific clades of active marine methylotrophs associated with a phytoplankton bloom in a temperate coastal environment. Appl Environ Microbiol 74: 7321.

Paerl, H. W., \& Millie, D. F. (1996) Physiological ecology of toxic aquatic cyanobacteria. Phycologia 35: 160-167.

Paerl, H. W., Bebout, B. M., \& Prufert, L. E. (1989) Bacterial associations with marine Oscillatoria sp. (Trichodesmium sp.) populations: Ecophysiological implications. $J$ Phycol 25: 773-784. 
Palková, Z. (2004) Multicellular microorganisms: laboratory versus nature. EMBO Rep 5: 470-476.

Pintner, I., \& Provasoli, L. (1958) Artificial cultivation of a red-pigmented marine bluegreen alga, Phormidium persicinum . Microbiol 18: 190.

Prufert-Bebout, L. (1993) Growth, nitrogen fixation, and spectral attenuation in cultivated Trichodesmium species. Appl Environ Microbiol 59: 1367.

Stein, J., Marsh, T., Wu, K., Shizuya, H., \& DeLong, E. (1996) Characterization of uncultivated prokaryotes: isolation and analysis of a 40-kilobase-pair genome fragment from a planktonic marine archaeon. J Bacteriol 178: 591-599.

Waterbury, J. B. (1991) The cyanobacteria: Isolation, purification, and identification. In The prokaryotes. Springer, pp. 2058-2078. 


\section{APPENDIX 2:}

\section{BIOLUMINESCENCE OF TRICHODESMIUM AND AN INVESTIGATION OF QUORUM SENSING BY MEMBERS OF TRICHODESMIUM CONSORTIA}

\section{INTRODUCTION}

A fortuitous observation that Trichodesmium colonies produce light measurable by a standard luminometer inspired a large portion of this thesis. In the ocean, bacteria and eukaryotes produce light; however, the light produced by bacteria and eukaryotes is quite different (Hastings, 1995). Eukaryotes produce light in pulses where as bacteria emit light continuously (Haas, 1980). To date, all luminescent bacteria regulate their light production by quorum sensing (QS) (Hastings, 1995). Here, we exploited this property of bacterial bioluminescence in order to identify bacterial QS within the phycosphere of Trichodesmium.

Eukaryotic bioluminescence is quite common. Dinoflagellates and ctenophores produce light which is easily observable at night in the wake of a ship or at beaches on summer nights (Hastings, 1995). Bacterial luminescence is less visible to the casual observer but is no less common in the ocean. Bacterial endosymbionts produce light in the light organs of numerous marine animals (Hastings, 1995), most famously, the Hawaiian bobtail squid. They have also been implicated as the source of luminescence in the impressive 'Milky Sea' displays which occur most frequently in the Indian Ocean 
(Nealson \& Hastings, 2006). Finally, bacterial luminescence has been observed on small spatial scales such as on particulate detritus in the ocean (Andrews et al., 1984).

As mentioned, the only known mechanism by which bacteria produce luminescence is via quorum-sensing regulated pathways (Hastings, 1995). Light is produced as a byproduct of a molecular-oxygen dependent enzyme catalyzed aldehyde reduction (Hastings, 1995). The genes for the requisite substrates and enzymes are part of a gene cassette linked to luxR (quorum sensing response regulator) in a QS-regulated operon.

The observation of luminescence on Trichodesmium led us to postulate the QS was utilized by epibiont bacteria associated with Trichodesmium colonies. QS by algalassociated bacteria has been implicated in the bloom-dynamics of other marine algae (Nakashima et al., 2006) and lacustrine cyanobacteria (Braun \& Bachofen, 2004), although not yet in association with Trichodesmium or any other marine cyanobacterium. However, QS has been observed to occur within cyanobacterial communities associated with stromatolites, although the role of QS is yet unknown (Decho et al., 2009).

The phycosphere of Trichodesmium is colonized by extremely high densities of bacteria (Sheridan et al., 2002). We confirmed this by performing scanning electron microscopy and epifluorence microscopy which are described in detail in Chapter 3 of this thesis (see Chapter 3 Figures 1 and 2). In addition to hosting extremely high densities of bacteria, biofilms (such as those which adhere to Trichodesmium) are known to be diffusion limited environments as well as having lower $\mathrm{pH}$ than their ambient environment (Horswill et al., 2007). These characteristics are all conducive to efficient 
QS. In this study, we investigated QS by epibionts of Trichodesmium spp. by observing luminescence, evaluating Trichodesmium cultures for the production of the QS signal, acylated homoserine lactone (AHL), and performing enzyme activity assays to evaluate the response of the community to exogenous AHL addition.

\section{METHODS}

\section{Luminescence}

Luminescence measurements were conducted with samples of Trichodesmium collected at the Bermuda Atlantic Time Series station in the Sargasso Sea (see Chapter 3 and 4 methods for additional details) as well as numerous laboratory cultivated strains of Trichodesmium. The following strains obtained from the Woods Hole Oceanographic Institution culture collection were evaluated for the production of bioluminescence: $T$. erythraeum strains K11131 and IMS101, T. thiebautii H94A . Luminescence was measured using a Turner Biosystems (Sunnyvale, CA) 20/20n luminometer.

\section{Evaluation of culture extracts for AHLs}

Batch cultures of Trichodesmium were extracted with organic solvents and analyzed for the presence of AHLs using the methods documented in Chapter 3 of this thesis. Extracts were evaluated by HPLC-LCQ-MS. 


\section{Enzyme activity assays}

Enzyme activity was assayed according to the methods introduced in Chapter 5 of this thesis. Details specific to this experiment will be described here. Experiments were performed on eighteen $10 \mathrm{~mL}$ two-week old batch cultures of T. erythraeum strain K11131. Triplicate cultures were amended with either 500 or $5000 \mathrm{nM}$ 3-oxo-C8-HSL, $500 \mathrm{nM}$ 3-oxo-C12 or $500 \mathrm{nM} \mathrm{C12-HSL.} \mathrm{3-oxo-C12-HSL} \mathrm{and} \mathrm{C12-HSL} \mathrm{are} \mathrm{not} \mathrm{readily}$ soluble in water and so were dissolved in DMSO. Triplicate control incubations to which no AHL was added, as well as control incubations to which only DMSO was added, were performed in parallel to the AHL-amended incubations. Amendments were added in 100 $\mu 1$ aliquots to the $10 \mathrm{~mL}$ cultures. Incubations were assayed for enzyme activities at one, six, and twenty-four hours as described in Chapter 5.

\section{RESULTS}

\section{Luminescence}

Bioluminescence of 13 individual tuft-colonies were measured at sea. Based on their luminescence values, they could be divided into a low luminescence group (Group 1) and a high luminescence group (Group 2). Group $1(\mathrm{n}=7)$ had an average luminescence which was 2.3 times that of seawater ( $32 \%$ standard deviation, Table 1). Group $2(n=6)$ displayed an average luminescence which was 5.9 times that of seawater $(23 \%$ standard deviation, Table 1). 8 puff-colonies were measured. On average, they were 2.1 times as luminous as seawater $(17 \%$ standard deviation, Table 1). The luminescence of seawater 
was practically indistinguishable from the background of the instrument at the time of measurement.

Laboratory strains also display luminescence although due to the high concentrations of individual trichomes in the culture media and the smaller size of the colonies, it was difficult to measure individual colonies. Instead, $1 \mathrm{~mL}$ from dense cultures were measured. T. erythraeum strain IMS101 produced as much as 12 times the luminescence of the intstrument background; T. erythraeum strain K11131 produced as much as 13 times the luminescence of the background and T. thiebautii produced 5 times the luminescence of background.

\begin{abstract}
AHLs
No AHLs were detected in field or batch cultures of Trichodesmium despite extensive efforts.
\end{abstract}

\title{
Enzyme Assay experiments
}

Although incubations were sampled at one, six and twenty-four hours, only the twentyfour hour results will be discussed here. AHLs did not induce enhanced protease, phosphotase, chitinase, $\alpha$-glucosidase actity or luminescence.

Enhanced lipase and $\beta$-glucosidase activities were observed in response to AHL amendments. 3-oxo-C8-HSL (500 nM and $5000 \mathrm{nM}$ ), 3-oxo-C12-HSL and C12-HSL enhanced $\beta$-glucosidase activity (Figure 2a). A DMSO-only addition was performed as a control and it enhanced activity of $\beta$-glucosidase to the same extent as the 3-oxo-C12- 
HSL and C12-HSL amendments. Thus we can not conclude these AHLs had any affect on $\beta$-glucosidase activity. However, 3-oxo-C8-HSL enhanced $\beta$-glucosidase activity to greater than ten times the activity in the no addition control. The ratio of activity in the amended sample to that of the control is greater than the control by two standard deviations. The effect of the high and low concentration 3-oxo-C8-HSL additions were indistinguishable.

AHL activities had a less dramatic although significant impact on lipase activity. 500nM 3-oxo-C8 HSL activity increased the activity of lipase by about $30 \%$ (Figure $2 \mathrm{~b}$ ). While this increase is small compared to the effect induced by 3 -oxo-C8-HSL on $\beta$ glucosidase activity (13-fold increase), the ratio of activity in the amended sample to that of the control is greater than the control by three standard deviations; we can say with greater than $95 \%$ confidence that the AHL amendment was effective. It is interesting to note that the $5000 \mathrm{nM} 3$-oxo-C8 treatment had no effect on the activity of lipase. 3-oxoC12-HSL and C12-HSL enhanced lipase activity although DMSO enhanced lipase activity as well; however, the enzyme activity induced by either C12-HSL or 3-oxo-C12HSL is significantly greater than that induced by DMSO alone (t-test, $p=0.04$ and $p=0.01$, respectively).

\section{DISCUSSION}

The phycosphere of Trichodesmium is an ideal environment for QS induction because of the high cell densities which are hosted within a diffusion-limiting EPS matrix. The observation of bacteria-like luminescence emitted from the colonies supported this 
hypothesis. We undertook this study in order to evaluate the occurrence of QS in Trichodesmium colonies.

We were unable to detect AHLs in organic extracts obtained from either field or laboratory-cultivated Trichodesmium samples. The extracts were measured using the LCQ-MS, which as suggested in Chapter 3, may not be sensitive enough to measure very low concentrations of AHLs which are likely to be produced within these colonies.

The extraction of AHLs from Trichodesmium colonies presents special challenges. First, while AHL concentrations in individual clonal colonies of bacteria may be quite high, these individual colonies represent a small component of the biomass within a large batch culture and thus the overall AHL concentration is likely to be low. Second, the polysaccharide matrix which provides the structure of the biofilm is very hydrophobic (Horswill et al., 2007) and likely competes with the organic solvent with respect to its chemical affinity for the AHLs. Finally, the biofilm matrix, if not completely disrupted during the extraction process, may protect clonal communities from the organic solvent thus preventing the extraction of AHLs. In consideration of the special challenges imposed by the structure of Trichodesmium colonies, it would be prudent to use the most sensitive analytical device available. In subsequent experiments, the FT-ICR-MS or triple quadruopole TSQ-MS are likely to achieve greater success.

In Chapter 3, we discovered that several strains of epibiotic bacteria associated with Trichodesmium from BATS produce AHLs. In this experiment, we added three of the AHLs (3-oxo-C8-HSL, C12-HSL and 3-oxo-C12-HSL) produced by BATS epibionts to batch cultures of T. erythraeum strain K-11\#131 and evaluated the effect these had on 
six common fluorogenic enzyme substrates. We detected a significant response in $\beta$ glucosidase and lipase activities; we did not detect an effect on the luminescence of the colonies. The upregulation of these two enzymes is interesting when compared to the results presented in Chapter 5 in which similar assays were performed on marine detrital aggregates. In Chapter 5, AHL was shown to upregulate the activity of protease, phosphotase and lipase. Upregulation of those particular enzymes makes ecological sense in the detrital-particulate environment because they serve to retain nitrogen and phosphorus in sunlit waters where they can support additional primary productivity. Here, we supplemented the Trichodesmium media with phosphorus and Trichodesmium likely supplies the colony with sufficient nitrogen. The enzymes upregulated in the phycosphere of Trichodesmium are therefore likely to be engaged in accessing the organic polysaccharide-based matrix.

We observed that the enzyme activities in samples amended with AHLs and those which had no amendments occurred in the relative intensities: lipase $>$ protease $>$ phosphotase $>\beta$-glucosidase $>\alpha$-glucosidase $>$ chitinase. It is interesting that although lipase and $\beta$-glucosidase were inducible by AHLs that $\beta$-glucosidase is less active than protease and phosphotase. Nausch and colleagues (1996) performed a similar enzyme activity survey on field populations of Trichodesmium collected in the Caribbean Sea. They report maximal phosphotase activity, followed by protease and $\beta$-glucosidase activity. Chitinase and $\alpha$-glucosidase activity were very low and lipase activity was not measured. That phosphotase is the most active enzyme in the latter data set likely reflects 
the nutrient availability in ambient waters at the time of collection, although this was not discussed.

Bacterial luminescence has been hypothesized to assist in the dispersion and propagation of bacterial species (Andrews et al., 1984). While this explanation may explain why luminescent enteric bacteria associate with faecal pellets, it does not necessarily provide a satisfactory motive for the association of luminescent bacteria with Trichodesmium as Trichodesmium spp. are not commonly found in the gut contents of zooplankton (e.g. Eberl \& Carpenter, 2007).

No eukaryotic or archaeal DNA were amplified from DNA extracts of Trichodesmium (discussed in Chapter 4 and Appendix 1), all observed luminescence must be of bacterial origin. To date, the only known bacterial luminescence mechanisms are regulated by QS. In addition, members of the K11131 consortia responded to the addition of exogenous AHLs by the upregulation of $\beta$-glucosidase activity as well as lipase activity. Despite the lack of detection of AHLs, two pieces of evidence support a role for QS in the Trichodesmium phycosphere. Further work will be required in order to assess the ecological impact of QS bacteria associated with Trichodesmiuum in the 'wild'. However, it is becoming evident that QS has important ecological and/or biogeochemical effects in the ocean and thus it will be excited to find out what role it plays in regulated the lifecycle of this globally important consortial cyanobacterium. 


\begin{tabular}{|lccccc|}
\hline & $\begin{array}{c}\text { sample } \\
\text { size }\end{array}$ & $\begin{array}{c}\text { average } \\
\text { luminescence }\end{array}$ & $\begin{array}{c}\text { Average } \\
\text { standard } \\
\text { deviation }\end{array}$ & $\begin{array}{c}\text { luminescence/ } \\
\text { seawater } \\
\text { luminescence }\end{array}$ & $\begin{array}{c}\% \\
\text { standard } \\
\text { deviation }\end{array}$ \\
\hline Group 1 Tufts & 7 & 281 & 31 & 2.3 & 32 \\
Group 2 Tufts & 6 & 714 & 23 & 5.9 & 24 \\
Puffs & 8 & 257 & 15 & 2.1 & 17 \\
Seawater & 8 & 121 & 8.3 & n/a & \\
\hline
\end{tabular}

Table 1. Table of compiled luminescence data collected at BATS. 

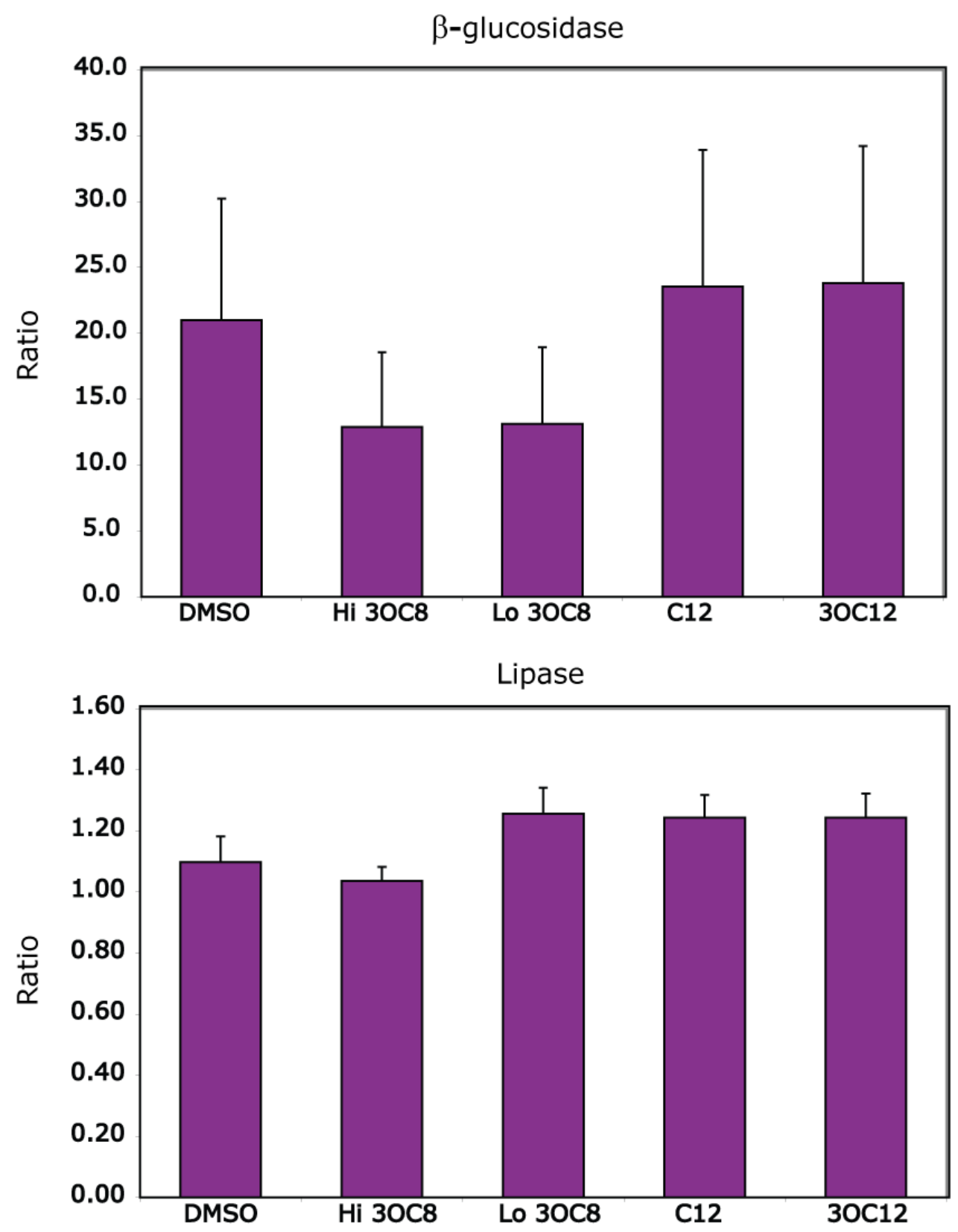

Figure 1. Results of $\beta$-glucosidase (a) and lipase (b) assays. Results are presented as ratios of experimental rates relative to unamended-control rates. Error bars are one standard deviation propagated from the error of replicate measurements of treated and control experiments. Note, the y-axis scale varies between (a) and (b). 


\section{REFERENCES}

Andrews, C. C., Karl, D. M., Small, L. F., \& Fowler, S. W. (1984) Metabolic activity and bioluminescence of oceanic faecal pellets and sediment trap particles. Nature 307: 539--541.

Braun, E., \& Bachofen, R. (2004) Homoserine-lactones and microcystin in cyanobacterial assemblages in Swiss lakes. Hydrobiologia V522: 271.

Decho, A. W., Visscher, P. T., Tomohiro, J. F., He, K. L., Przekop, K. M., Norman, R. S., \& Reid, R. P. (2009) Autoinducers extracted from microbial mats reveal a surprising diversity of $N$-acylhomoserine lactones (AHLs) and abundance changes that may relate to diel pH. Environ Microbiol 11: 409-420.

Eberl, R., \& Carpenter, E. J. (2007) Association of the copepod Macrosetella gracilis with the cyanobacterium Trichodesmium spp. in the North Pacific Gyre. Mar Ecol Prog Ser 333: 205.

Haas, E. (1980) Bioluminescence from single bacterial cells exhibits no oscillation. Biophys J 31: 301-312.

Hastings, J. W. (1995) Bioluminescence. In Cell physiology source book. N. Sperelakis (ed). Academic Press, pp. 665-681.

Horswill, A. R., Stoodley, P., Stewart, P. S., \& Parsek, M. R. (2007) The effect of the chemical, biological, and physical environment on quorum sensing in structured microbial communities. Anal Bioanal Chem 387: 371-380.

Nakashima, T., Miyazaki, Y., Matsuyama, Y., Muraoka, W., Yamaguchi, K., \& Oda, T. (2006) Producing mechanism of an algicidal compound against red tide phytoplankton in a marine bacterium $\gamma$-proteobacterium. Appl Microbiol Biot 73: 684.

Nausch, M. (1996) Microbial activities on Trichodesmium colonies. Marine ecology progress series.Oldendorf 141: 173-181.

Nealson, K. H., \& Hastings, J. W. (2006) Quorum sensing on a global scale: Massive numbers of bioluminescent bacteria make Milky Seas. Appl Environ Microbiol 72: 2295-2297.

Sheridan, C., Steinberg, D., \& Kling, G. (2002) The microbial and metazoan community associated with colonies of Trichodesmium spp.: a quantitative survey. J Plankton Res 24: 913-922. 


\section{APPENDIX 3:}

\section{MEASUREMENT OF THE ACTIVATION ENERGY OF HEXANOYL- HOMOSERINE LACTONE IN ARTIFICIAL SEAWATER}

The activation energy of C6-HSL degradation in artificial seawater was calculated from the degradation rate of C6-HSL measured at temperatures of $3^{\circ} \mathrm{C}, 24^{\circ} \mathrm{C}$, and $37^{\circ} \mathrm{C}$. The degradation rate of C6-HSL was determined as described in Chapter 2 (published as Hmelo \& Van Mooy, 2009). The natural log of the rates was plotted against the inverse of the temperature (see Figure 1) and modeled using the Arrhenius equation (Atkins, 1998):

$\ln k=\ln A-\frac{E_{a}}{R T}$

where $\mathrm{k}$ is the turnover rate, $\mathrm{A}$ is the Arrhenius constant, $\mathrm{E}_{\mathrm{a}}$ is the activation energy for the reaction of hydroxide ions with AHL, $\mathrm{R}$ is the universal gas constant, and $\mathrm{T}$ is the temperature in Kelvin at which the incubation was conducted.

The degradation rate of C6-HSL increased predictably with temperature (Figure 1). By modeling the data with the Arrhenius equation, we determined that the activation energy of C6-HSL in artificial seawater is $83 \mathrm{~kJ} / \mathrm{mol}$. From the activation energy of C6HSL in artificial seawater, we calculated a $Q_{10}$ of 3.6. $Q_{10}$ is a coefficient is a measure of the change in the rate of a reaction with a $10^{\circ} \mathrm{C}$ increase in temperature. Our calculated 
$\mathrm{Q}_{10}$ value was higher than that found previously in pure water (2.0, data from Yates et al., 2002) indicating a greater temperature sensitivity in seawater.

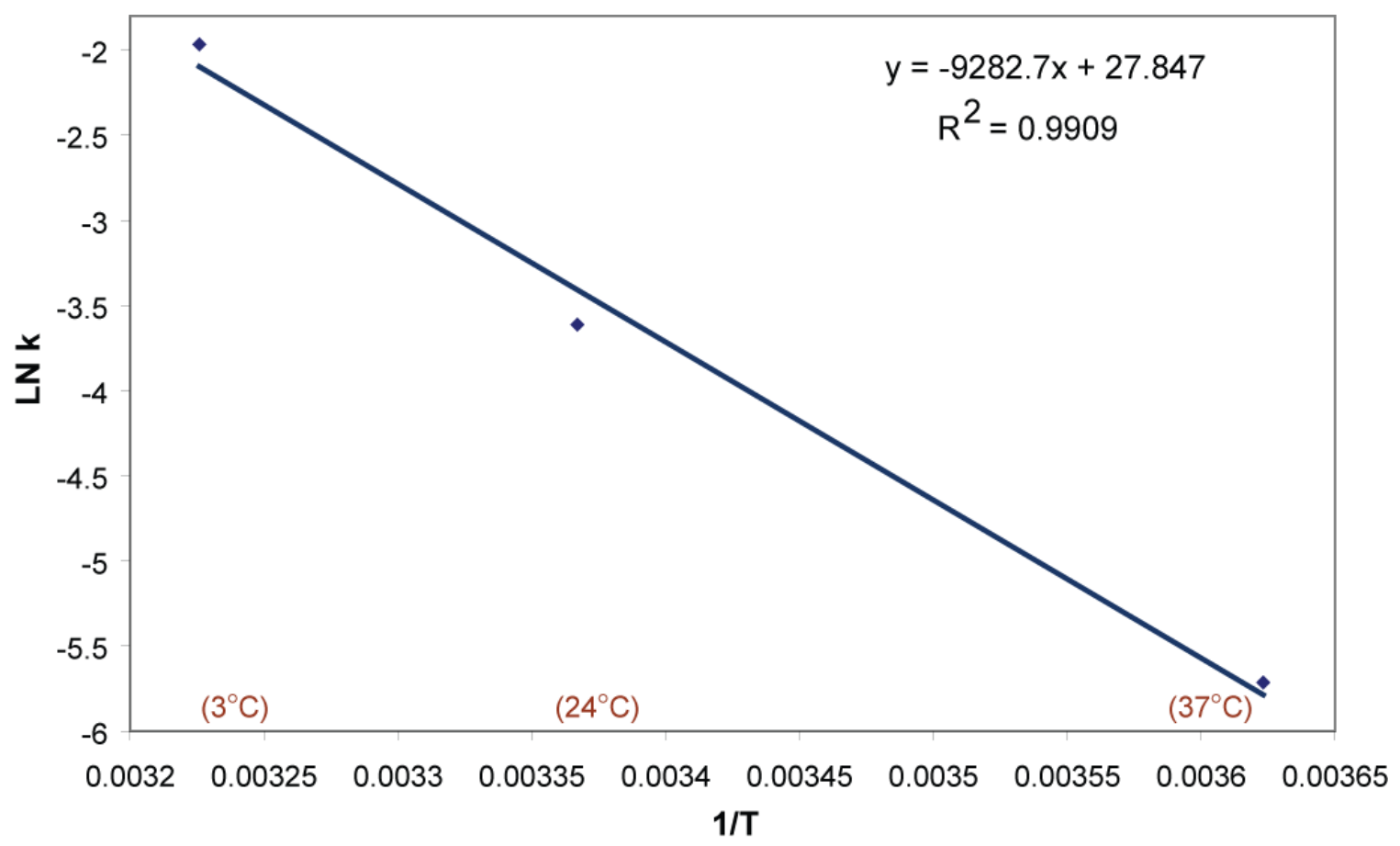

Figure 1. Plot of the natural log of the degradation rate of C6-AHL in artificial seawater versus the temperature at which the rate was measured. The slope of the line is equal to $-\mathrm{E}_{\mathrm{a}} / \mathrm{R}$, see text for details. 


\section{REFERENCES}

Atkins, P. (1998) Physical Chemistry. 6th edn. New York, W.H. Freeman and Company, $999 \mathrm{pp}$.

Hmelo, L., \& Van Mooy, B. A. S. (2009) Kinetic constraints on acylated homoserine lactone-based quorum sensing in marine environments. Aquat Microb Ecol 54: 127133.

Yates, E. A., Philipp, B., Buckley, C., Atkinson, S., Chhabra, S. R., Sockett, R. E. et al. (2002) N-Acylhomoserine lactones undergo lactonolysis in a $\mathrm{pH}-$-, temperature-, and acyl chain length-dependent manner during growth of Yersinia pseudotuberculosis and Pseudomonas aeruginosa. Infect Immun 70: 5635-5646. 